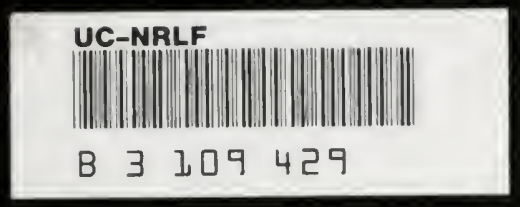



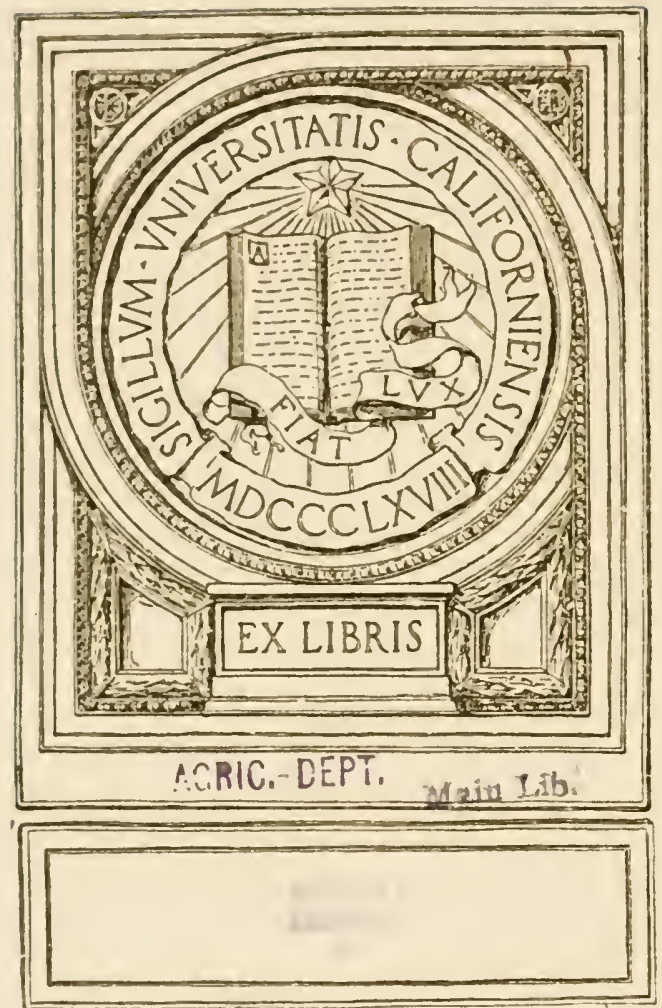
Digitized by the Internet Archive in 2008 with funding from Microsoft Corporation 



MAINE

AGRICULTURAL EXPERIMENT STATION ORONO, MAINE.

CHAS. D. WOODS, Director

\section{POULTRY DISEASES AND THEIR TREATMENT}

ORONO, MAINE,

FEBRUARY, I9II. 


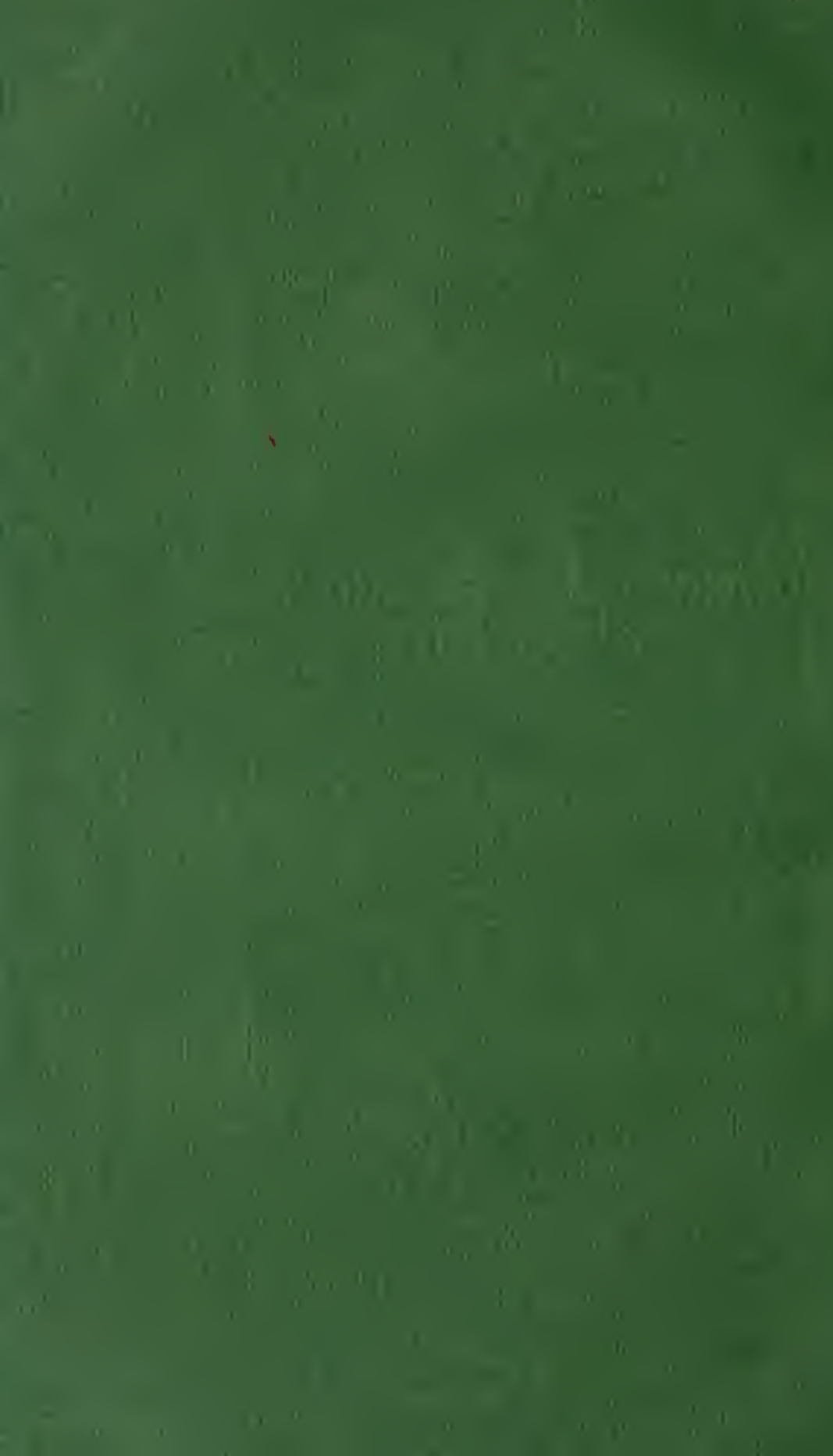


MAINE

AGRICULTURAL EXPERIMENT STATION

ORONO, MAINE.

\section{POULTRY DISEASES AND THEIR TREATMENT}

Compiled by

Rayarond Pearl, Frink M. Surface, and Maynie R. Curtis.

ORONO, MAINE.

FEBRC.IRY, IOII. 

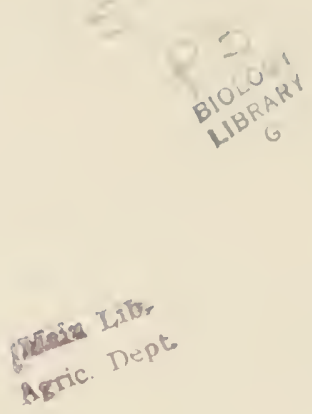

COPYRIGHT, 19 I I

BY

Mane Agricultural, Experiment Station.

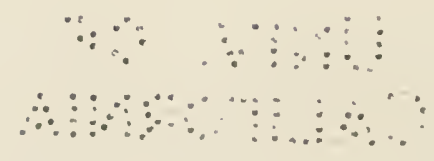

This publication is mailed free to residents of Maine.

To others the price is twenty-five cents per copy. 
TARLE OF CONTHATS.

PAGE

Introduction

Chapter I. General Considerations Regarding the Treatment of Poultry Diseases ................. 4

Prevention Kather than Cure the leleal.......... 5

Breeding for Health, Vigor and Somnd Constitution

Chapter II. Poultry Hygiene ...................... 9

Poultry Honse Hygiene and Sanitation...... I0

How to Clean a Poultry House........ Io

Disinfection ................. I I

Formaldehyde Gas Disinfection..... I 2

Cresol Disinfectant ............ I2

Fresh Air and Light.............. I4

Aroid Dampness ................ ${ }^{5}$

Provide Clean and Dry I,itter......... 15

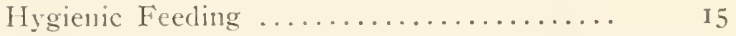

Aroid Overteeding ................ 15

Provide Plenty of Circen Food.......... I6

Provide Firesh and Clean Drinking WVater $\quad$ I6

The Land ....................... I8

Exercise ....................... 20

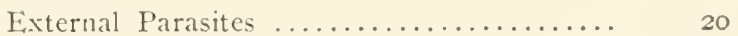

Disposal of Dead Birds.............. 20

Isolation of Sickness ................ 2I

The Essentials of Poultry Hygiene........ 2I

Chapter III. The Diagnosis of the Diseases of Poultry...... 22

External Symptoms ................ 22

Post-Mortem Examinations ...................... 24

How to Make a Post-mortem......... 25

Chapter IV. Poultry Materia Medica ................ 28

The Medicine Chest ............... 28

An Antiseptic Ointment ............. 30

Tables of Apothecaries' Weights and Meas-

ures and Their Metric Equivalents...... 3 I

Chapter $V$. Diseases of the Alimentary Tract........... 32

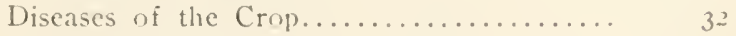

Impacted Crop (Crop Pound)....... 32

Inflammation of the Crop.......... 34

Emlarged Cirnp ................. 36 
1)iscases of the Stomach (Proventriculus)..

P.AGF Intammation wi the Stmmach (Gastritis)

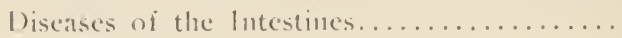

Simple Diarrle: $\ldots \ldots \ldots \ldots \ldots \ldots \ldots \ldots$

Enteritis (Dysentery) $\ldots \ldots \ldots \ldots \ldots \ldots$

Constipation $\ldots \ldots \ldots \ldots \ldots \ldots \ldots \ldots \ldots$ 4I

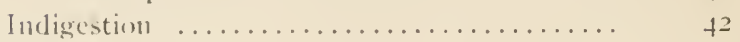

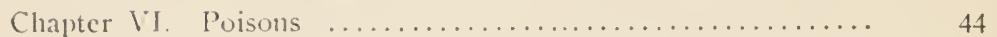

Commun Silt, Nitrate of Soda, Lyes...... 44

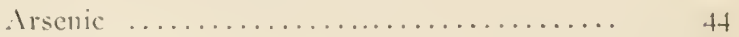

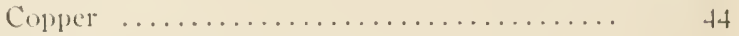

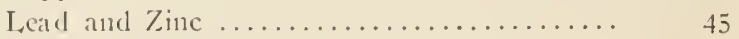

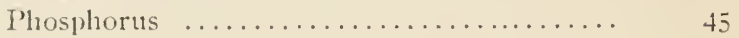

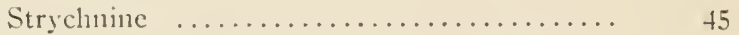

Eirgot of Rye .................. 45

Treatment for Poisons in General........ 46

Chapter YII. Diseases of the Liver................. 47

Hypertroply or Enlargement of the Liver... 50

Fatty Degeneration .................. 5 I

Atrophy or llasting of the Liver........ 52

Congestion and Inflammation of the Liver... $5 z$

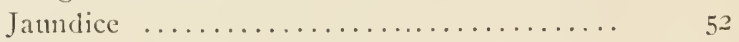

Blackhead (Infectious Entero-Hepatitis).... 53

Cercomoniasis ........................... 55

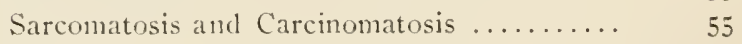

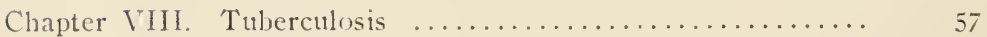

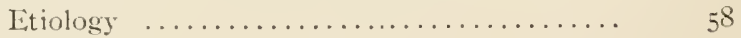

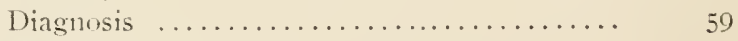

Methods of Contagion $\ldots \ldots \ldots \ldots \ldots \ldots \ldots . \ldots \ldots$

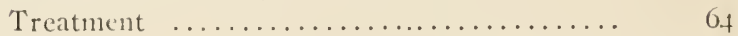

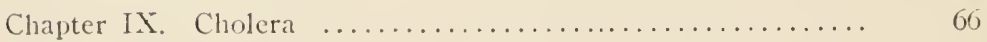

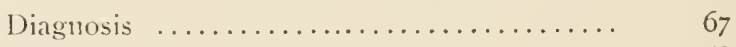

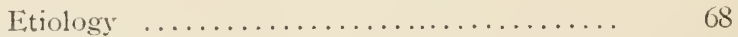

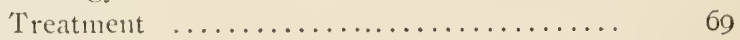

Chapter X. Diseases of the Abdominal Cavity............ 72

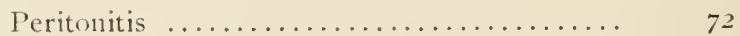

Abdominal Dropsy or Iscites.......... 73

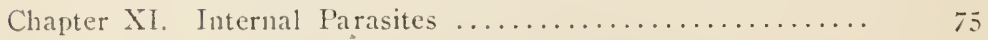

D)iagnosis of llorms in (ieneral......... 75

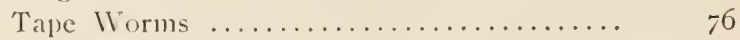

Nodular Treniasis $\ldots \ldots \ldots \ldots \ldots \ldots \ldots \ldots \quad 77$

Round Worms .................. $8_{2}$

Flukes $\ldots \ldots \ldots \ldots \ldots \ldots \ldots \ldots \ldots \ldots \ldots \ldots$

Chapter XII. Diseases of the Respirantory System......... 85

Anatomy and Physiology ............. $8_{5}$

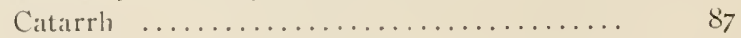

Bronchitis (Crotu) ) .............. 88

Influenza (Epizootic, Grippe, Distemper).... $\quad 89$ 
Rutu (Contagious (atarrh, l)iptleria, I)iptleritic Roup, Canker) .............. go

"l'ip)" (lntlanmation of the Mtouth) ...... IO.

Canker ..................... 103

Thrusli ...................... 103

Aspergillusis (Mycosis of the dir Passages) 104

Congestion of the lonngs............. Io -

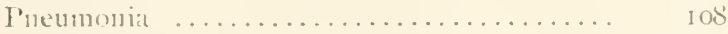

Tuberenlosis ..................... IIO

Tle dir-sac Vite ................. II0

Clapter XIII. Diseases of the Circulatory System and IBlood.. II

Pericarditis (Intlammation of the Iericar(limin. I)ropsy of the Heart Sac) ........

Endocarditis (Inflammation of the Internal Membranes of the Heart)........... II

Myocarditis diptheritica ............. II 3

Enlargement of the Heart (Hypertrophy).. II3

Rupture of the Ileart and Large Blood Vessels .......................... II 3

Diseases of the Blood.................. IIf

Infectious Letkemia ............... IIt

Chapter XIY. Diseases of the Nervous System........... IIS

Apoplexy (Hemorluage of the Bratin)..... If

Heat Prostration ................... II

Congestion of the Brain (Vertigo, Cerebral

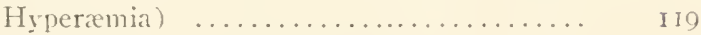

Iipilepsy .................. II

Chapter XY. Diseases of the Kidneys, Rhenmatism and Lim-

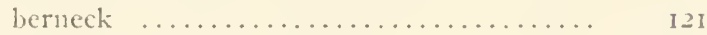

Gout ..................... I I

Visceral Gout ................... I2I

Articular Gout ................. I I

Other Diseased Conditions of the Kidney:... I 2 I

Rheumatism ................... I 23

Limberneck .................... I 23

Clapter XVI. External Parasites ................ I 24

heeping a Poultry Plant liree from External Parasites ................... I 24

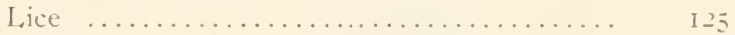

How to Make an Effective ancl Very Cheap lice Powder ............. I 30

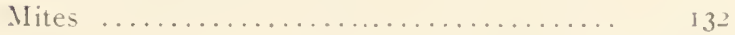

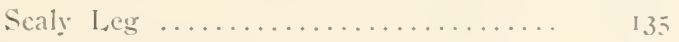

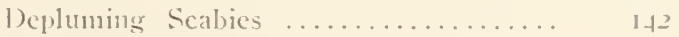

Other Mites Iffecting Poultry....... $1 \mathrm{H}$

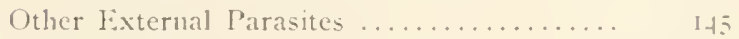

Chapter XVII. Diseases of the Skin ..................... It

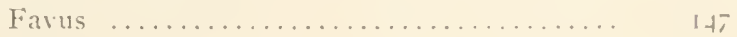

White Comb .................. 1,50 
Clicken Pox (Sore Head or Epithelioma

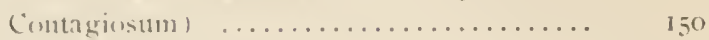

Chapter XVII1. Diseases of the Reproductive Organs........ I55

Inatrmy and Plysiology ............. I55

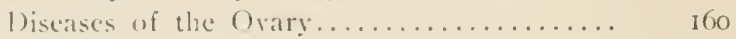

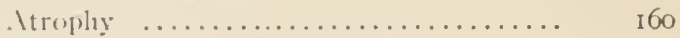

(iangrence of the Ovary............ 163

() arian Tumors ............. $\quad 163$

Mhortion of Egggs ................ I6t

lolk lippertrophy ............. $16_{4}$

Fitilure of Follicle Wall to Rupture.... I $\quad 16_{5}$

Diseases of the Oriduct ............. I6 165

Inflammation $\ldots \ldots \ldots \ldots \ldots \ldots \ldots \ldots \ldots . \quad 165$

Prolapse of the Oriduct.......... I0

Obstruction of the Oriduct (Egg Bound) I60

Rupture of the Oviduct........... I $\quad$, 3

Cangrene of the Oriduct.......... I7t

Ireaking of Eigg in Oviduct........ I

Mnormal Eggs ..............

Vent Gleet $\ldots \ldots \ldots \ldots \ldots \ldots \ldots \ldots \ldots$ 177

"Break Down" ............... I $\quad$ I79

Diseases of the Male Reproductive Organs.. 180

Chapter XIX. Diseases of Chickens ................ Is

White Diarrhea $\ldots \ldots \ldots \ldots \ldots \ldots \ldots \ldots \ldots,{ }_{1} s_{1}$

Intestinal Coccidiosis $\ldots \ldots \ldots \ldots \ldots \ldots, \quad{ }_{1} \&_{3}$

Bacillary Virite Diarrhea .......... I86

Diagnosis of White I)iarthea in General 189

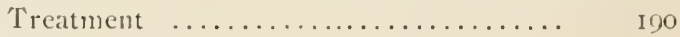

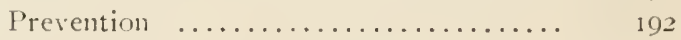

Leg Weakness ................... 192

Aspergillosis or Pneumomycosis ........ 193

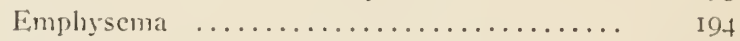

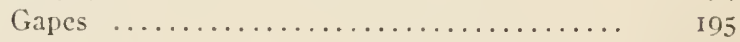

Chapter XX. Poultry Surgery ................... 201

The Treatment of Cuts, Tears and All Open

Hounds ........................ 2OI

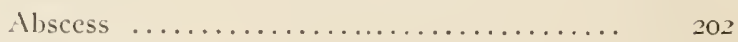

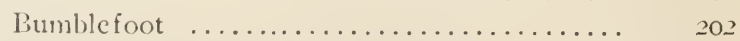

Broken Bones .................... 203

Frozen Combs and Wattles........... 203

Anesthetizing Poultry .............. 203

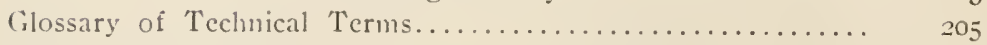

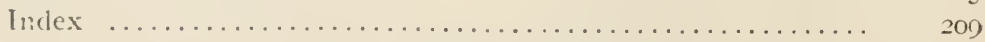


L.IST OF ILLUSTRATIONS.

Fig. I. Showing condition of liver in "blacklead." (Modified PAGE after Moore) ........................ 54

Fig. 2. Breast bone of a fowl showing excessive emaciation in tuberculosis. (After W $1 \mathrm{ard}$ ) .............. 60

Fig. 3. Liver of fowl affected with tuberculosis. (Aftes

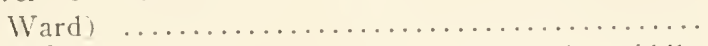

Fig. 4. Spleen from tuberculous fowl cut through the middle.

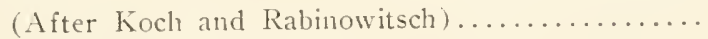

Fig. 5. Intestine and mesenteries of a fow affected with tuber-

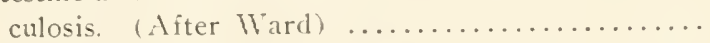

Fig. 6. Drepanidotacnia infundibuliformis, a tape worm of the

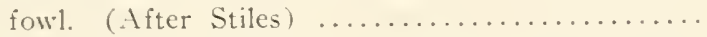

Fig. 7. Intestine of a fowl turned wrong sidle out to show tape worms in nodular faniasis (After Pearson

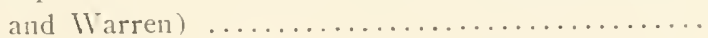

Fig. 8. Sketch showing method of introducing turpentine directly into crop. (From Gage and Oppermas )....

Fig. 9 Worms protruding from a section of the intestine of a fowl. (Ifter Bradshaw) $\ldots \ldots \ldots \ldots \ldots \ldots \ldots$

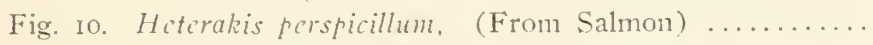

Fig. Ir. Trematode worm or fluke showing internal structure.

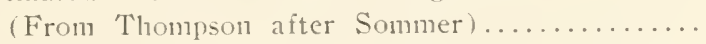

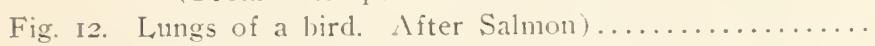

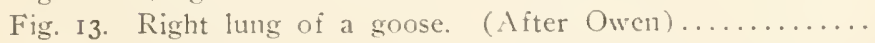

Fig. 14. A lobule of the lung of a bird represented in ideal

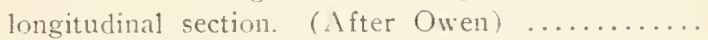

Fig. 15. Showing appearance of hen a day before death from

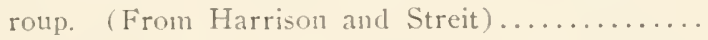

Fig. 16. Showing swelling of head in severe roup. (From

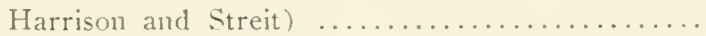

Fig. I 7 . Head of a bird. The lower figure shows the maxilloocular sinus, which opens into the socket of the eye and communicates with the nasal cavities. The upper figure shows the roup tumor on the head caused by the filling of this cavity with cheesy pus. (From

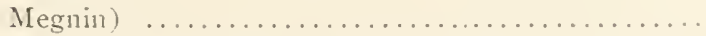

Fig. 18. Head of a fowl 22 days after inoculation with a culture of the roup bacillus. (From Harrison and Streit) 
IFig. I1. Throat and buttum of motuth with false membrane

PACi: (iil) If days after jurneulation. (brom Harrison

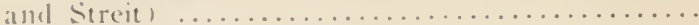

lijg. 20. I section of a filse membrame of a rump iowl. (lirom

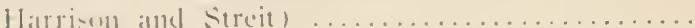

lög. 21. Heat uf a hurel with diphtheritic roup affecting the month and tongue. (liom Megnin) ..........

Fing. 22. Aspervillus fumigatus. Greatly enlarged. (. Witer

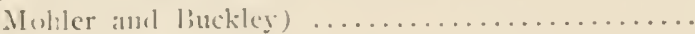

Fig. 23. Cytodifes nudus. The air sac mite. (Aiter Theo-

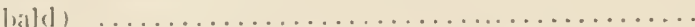

ling. 24. The common hen lonse (Mcnopon pallidum). Greatly

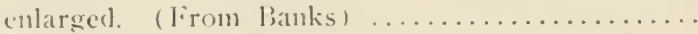

I 26

Fig. 25. Lifenrus a ariabilis. A louec that infests poultry. Much ('nlargerl. (lirom Bankis atter Demuy ) .........

Fig. 26. Coniodes dissimilis. I lonse that infests poultry Mrch enlareel. (From Banks after Dennyy)......

ligr. 27. lieathers slowing eggs or "nits" of the common hen fouse. lislarged. (O) riginal) $\ldots \ldots \ldots \ldots \ldots \ldots \ldots$

I0ig. 2s. The common "red mite" of poultry, Dermanyssus gal-

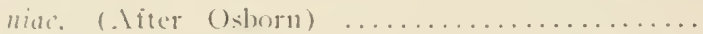

Fig. 29. I. Nirmal leg of lien. B. Leg nf hen affecterl with scaly leg. (. Ifter Megnin)

Fig. 30. Photograph of the leg of a hen affected with scaly leg. (. Ifter Haiduk)

Fig. 31. Photograph of the adult female of the mite Knemidocoptes (Dermatoryctes) mutans. After Haiduk)..

Fig. 32. Photograph of the six-legged larvae of Knemidocoptes

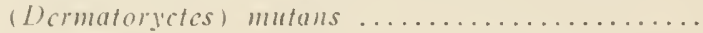

Fig. 33. Section of the skin of the leg of a fowl affected with scaly leg. linlarged. (After Haiduk) .........

Fig. 34. ligg containing female Sarcoptes lacitis var. gallinac. (From Theobald) ......................

Fig. 35. Symplectoptes cysticola. Comnective tissue mite.

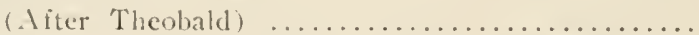

Fig. 36. "Harvest bug." Tctranychus (Leptus) autumnalis, lar-

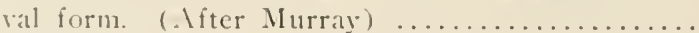

Fig. 37. Head and neck of a fowl affected with generalized

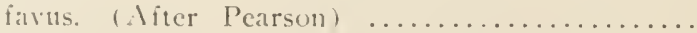

Fig. 38. The fungus . lichrion schonlcinii which causes farus

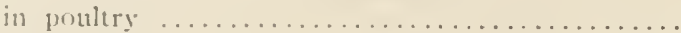

Fig. 39. Sore-head crusts on comb, eye-liels and skin. ( $\lambda \mathrm{fter}$ Cary)

Fig. to. The reproductive or egg-producing organs of a hen. (. Ifter Duval)

Fig. fI. Sluwing shapes of abnormal eggs sometimes found. (From won Durski after I andois) .......... I6I

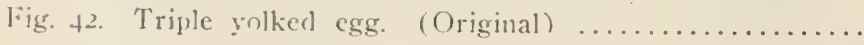


Fig. 43 Showing shapes of abnomal eggs sometimes found.

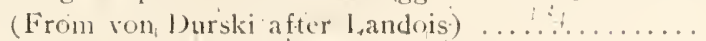

PAGE

Fig: 44. Diagrammatic representation of the life history of a
Coccidium. (Ifter Cole and Hadley) $\ldots \ldots \ldots \ldots$.

Fig: 44. Diagrammatic representation of the life history of a
Coccidiun. (Nfter Cole and Hadley) $\ldots \ldots \ldots \ldots$. I 84

Fig. 45. Ten-day White Leghorn chichs phowing symptoms of bacillary white diarrhea. (Xfter Rettger and

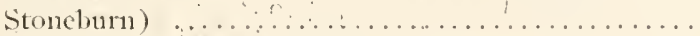

Fig. 46. Normal ten-day White Leghorn-chicks. (After Rett-

Fig. 47. Trachea (windpe) of a pheasant, showing gape I 89 worms (Syngamus trachealis) attached to the nu-

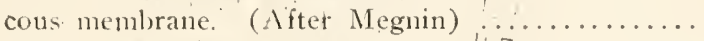

Fig. 48. A pair of Syngamus tractucalis attached. (After Meg-

Fig. 49. A pair of Syngamus trachealis (After Megnin) ... 196

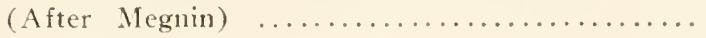



PULITRI DISEASES AND THEIR TREATMENT.

\section{INTRODUCTION.}

It is probably safe to say that considerably more than 50 per cent of the correspondence of those engaged in ponltry work in the agricultural colleges and experiment stations in this country relates to poultry diseases. The poultryman or farmer sees that some, or perlaps all, of his birds are ill, and he straightway writes to the nearest college or station to know what the discase is, and what to do for it. The Maine Station has for many ycars been the recipient of a great number of such inquiries. It is an unfortmuate, but in the nature of the case an unavoidable fact, that in many instances it is quite impossible to make any really satisfactory reply to these inquiries. In the vast majority of cases the person who writes the letter is cuite untrained in pathology and either describes no symptoms at all or cnly those very general ones which are common to nearly all the ills of poultry. To one who has not handled this class of correspondence it would seem almost incredible that there should be so many letters of the following type: "I have lost about a third of my chickens in the last few days. They seen a little dumpish for a while and then die. What is the tronble and what shall I do for it ?" To diagnose and prescribe on such a basis of information is impossible. Yet the hard fact remains that the correspondent's chickens were ill and did die, and he necds help to get ont of the trouble.

To meet this need so far as possible, and in response to a definite request on the part of the organized agricultural interests of the State the present work has been prepared. What it aims to do is to give a clear and reasonably complete compilation and digest of the information now existing in the literature regarding the commoner diseases of poultry. their diagnosis, ctiology, treatment and prognosis. It should be clearly unclerstood that the book is essentially a compilation. The Maine Station has never conducted any special investigations regarling poultry diseases, and does not propose to in the imme- 
diate future at least. No one connected with the Station at the pesent tince has any expert, fist hand knowleclge of pumltry pathology: 'This locing the case, the Station assumes no responsibility for the contents of this book beyond that involved in the compilation and exliting. That is to say the Station does not guarantec that any of the renerlies or treatments herein proposerl will cure any diseased condition. It merely puts before the public what appears to be the best and most reliable information now existing regarding these matters. If this information is incomplete, or fails in the attainment of the desired end, the fatlt lies with the original anthority not with the compiler. Firtlue it should be said that no attempt has been made to discuss all the detailed technical accounts of the scientific sturly of avian pathology, appearing in technical journals in this comntry and Enrope, and the work is, therefore, not complete in this sense. This material is primarily of interest only to the profescional sturlent of pathology. 'This book is not written for him at all, but for the practical poultryman.

It is not intended that this hook should displace any of the stanclard works on diseases in the ponltryman's library. On the contrary it is intended merely to supplement these. In fact the writers would most urgently arlvise that every poultry keper buy either one or both of the following books:

"The Common Sene Poultry Doctor" by John H. Robinson. Farm I'oultry Publishing Co., 232 Summer St., Boston, Mass. Price 5oc. This secms to the writers to be, on the whole, the best existing book on diseases for the practical poultryman.

"'The Diseases of Poultry:" By Dr. D. E. Salmon. For sale by Schmid's Rird \& l'et Stock Emporimm, 712 Twelfth St., N. IV., Washington, D. C. Price 5oc. This book gives a more thorough treatment of the subject, but is written rather more from the standpoint of the veterinary practitioner than from the standpoint of the practical poultryman.

In writing this work free use has been made of the standard anthorities on the subject. including the books cited above, as well as the following:-

"Diseases of l'oultry," by Lconard Pearson.

"Farm Poultry Doctor," by N. IV. Samborn.

"Reliable T'oultry Remedies." pulblished by the Reliable Publishing Co.. Quincy, Illinois. 
"Die Krankheiten des Ilansgeflügels," by F. A. Züru.

"Nannal of Ponltry Diseases." by Tale.

"Diseases of Poultry." by Fi. Wiodroffe Hill.

. Mso use has been made of the portions of standarel works on poultry husbandry. which deal with disease.

In every case acknowledgement is made to the authorities cited. 


\section{CHAP'TER I.}

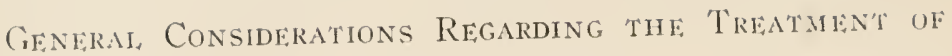

\section{POUltiry DISLASES.}

There is general agreement on the part of authorities on poultry pathology and practical poultrymen of long experience that in general. "doctoring" poultry is not advisable. The reasons for this attitude are primarily the following:

I. The unit of production with poultry (i. e., the individual bird) is of relatively small value, and if a man's time is worth anything it is too valuable to spend treating sick chickens individually unless they are show specimens of great individual value.

2. The "cured" chicken is a menace to the owner, because its identity is likely to be overlooked or forgotten, with the result that it goes into the breeding pen and perpetuates through its offspring the constitutional weakness which was one fundamental factor in bringing about the result that it, rather than some oi its fellows, was ill.

This point of view has been well stated by Mright in the following words:

"In a large proportion of cases of risease, the birds ought to die or be killed. Even where there is no constitutional taint, the fact that they have succumbed to circumstances which have not affected others, marks them out as the weakest, which nnaided Nature would assuredly weed out, and which if we preserve and breed from, perpetuate some amount of that weakness in the progeny. Rhemmatism, for instance, can be cured; of that there is no doubt. But the vast majority who have had such success, agree that the effects are either neicr recovered from as regards strength and vigor, or else that the original weakness continues; and the same may be said of some severe contagions diseases, such as diphtheritic roup, which may affect the strongest. On the other hand, many diseases also apparently contagious, and so attacking healthy birds nnder certain predisposing conditions of exposure or other coincident strain upon the system, do not ap- 
pear to leave serious results behind them, and are tolerably definite in symptoms and character. It is these which may be most successfully treated, and in which treatment is most worth while where fowls of value are concerned. But it is significant that nearly all breeders who rear really large numbers of poultry, gradually come to the conclusion that, except in special cases, with valuable biris, the most economical treatment of serious disease occurring in a yard is-execution. Concerning this matter each must judge for himself."

In the case of the utility poultryman, keeping poultry solely for the eggs and meat they produce, practically the only diseased conditions which it will pay him to treat at all are those in which the treatment can be applied to the flock as a whole, without the necessity of handling individual birds. Thus, for example. in cases where the flock "goes off its feed," or has simple indigestion or a simple cold, the birds can be treated successfully as a flock. On the other hand, in the case of the fancier. who has individual birds of considerable value there will be a much wider range of diseases which he will feel that it is profitable for him to treat. There are, of course, certain diseased conditions which demand individual treatment, but in which the treatment is so simple and the ontcone is almost certain to be so good, as to justify its employment even in the case of birds of ordinary value. An example of such a condition is found in a crop bound bircl. Robinson sums the matter up very well in the following basic rule for poultry doctoring:

"Give treatment when it can be applied to a flock conveniently and with reasonable expectation of beneficial results, and treat individuals, if necessary, when treatment is simple, easy, and needi to be administered but very few times."

\section{Prointion Rather Than Cure the Idcal.}

The aim of every poultry keeper, whether his interest is in the fancy or the utility end of the business, should be to breed and manage his birds so as to prevent entirely, or reduce to a minimum, the occurrence of discase. In other words, the attitude should be that the end to be sought is to prevent the occurrence of clisease. rather than to rely on a rather (lubious ability to cure it after it is there. Sucl a standpoint is sound from erery point of view; it is in line with the whole development of modern medicine. The poultry doctor should regard his function 
as the sance as that of the Chinese plysician, who is primarily cmployed to keep the patient from lecoming ill, only secondarily to clire hints.

Now there are fundamentally two factors involved in the continterl maintenance of good health in potnltry (or, for the matter of that, in any other animal). These are:

1. A sound and aigorous constitution, which if present. is something innate and "bred in the bone," and which, if absent, must be bred into the stock.

2. A system of poultry management (including fecding, housing. itc.) which is thoroughly and absolutely hygicnic.

Let us consider each of these factors separately in some detail.

Brecding for Health, Tigor, and Sound Constitution.

To have a high degree of constitutional vigor in the foundation stock is one of the most certain assurances that the poultryman will not be trombled with disease. This is of primary importance. In order to breed constitutional vigor into the flock the poultryman must train himself to recognize at a glance the condition of his birds. Are they in good condition or not? Regarding the aspect of fowls in health and disease Salmon has the following to say:

"Ile say that a bird is in good health when it appears lively. has a clear cye, a bright red comb, is quick and active in its morements, lias a good appetite and when the various organs perform their functions in the manner in which they are observed to act in all birds that are vigorons and thriving. On the other hand. we say a bird is diseased when some function or functions of its body are not performed as they are the great majority of individuals, or when some organ presents an unusual form or appearance. Disease has, therefore, been defined as a life the manifestations of which deviate more or less from the normal. Practically, we say a bird is diseased when we observe that one or more of its functions are not carried on in a normal manner. or when we find unusual growths, injuries, or parasites affecting any of its organs."

In a recent article Dr. P. 'T. Woods (Amer. Ponlt. World. lol. 1, Jan. 1910) gives sonne excellent advice in regard to breeding for health and vigor. This is, in many respects, the hest brief stmmary of this inportant subject which we have been able to find in the literature. He says:- 
"The Health Type-For all practical purposes, the type of health and strength and the type of weakness, of lacking bodily vigor, are easily differentiated. Do not mistake the purely nervons energy of closely bred thoromghbreds for an indication of vigor. This may be simply the mettlesome spirit of the thoronghbred ancl alone is of no great value as a guide to health : combined with satisfactory physical qualities it is a desirable asset."

"Choosing the Male Bird.-Always hear in mind that the male bird is for all practical purposes half of the flock. The male shonld be fully matured, well developed specimen, neither too youmg nor too old. Male birks from twelve months to two and one-half years old usually make the best breeders. He slould be the son of sound healthy parents and should, so far as possible, inherit from then the qualities which are desired for clicks of his get. He should be particularly strong in all points or physical vigor, and Standard repurements, where his mates show any traces of weakness. [fave him as nearly perfect in Standarel shape as possible, and of medimm size and weight for the variety. Too heavy males often serionsly injure their mates and are not clesirable in the breeding pen."

".'The hearl should he rather large, hroad and of good shape. well carried. The cye should be bright, romel and full with $n$ irregularities in shape of pupil. The comb, face and wattles shoukl be a good healthy color, neither too pate nor too dark. The beak should be rather short, stont and set well at the base. The long. flattened beak of 'crow hearled' birds or the misshapen "hawk bill are almost certain signs of physical weakness. The neck should be of medium length for the variety and rather full; the long. thin, 'scrawny' neck goes with the "crow hearl.'

"The boxly should be well filled ont and carried in the wellset-11) manner indicative of a well orecered system of nutrition,a genod eligestion. The plumage should be bright. lustrous and casticel rather dosely for the variety."

"Mopey, cloper, loosely feathered birds with dull plumage and a listless "don't care for life" manner are too short on gool health to he of value as breeling stock."

"The legs slould be medium short for the variety, strong and rather large bened and set well apart. The keel bone should be firm and straight. There should be no deformities." 
"Leggy birds, knock-kneed and with crooked breast bones are always lacking in physical vigor even if it does not show on the surface."

"The male shonlel be attentive and gallant to lis mates, should have a clear lusty crow, free from any ratte at the end. He should be sound in wind and able to fight or rum without shortness of breath or livid appearance of face and comb."

"A good breeder will have a good appetite and will usually be of a rather 'scrappy' disposition, disposed to resent any interference with his mates by other fowls or by the attendant."

"Choosing the Female.-The female should be a well-grown, well-dereloped, full;-1natured pullet or somel and vigorous yearling or two year olel. The health type will be active, alert and inclined to be talkative, 'singing' cheerfully, and rlisposed to scratch and forage. She is usually the first off the roost in the morning and the last to go to berl at night. Head, eye, conclition of plumage and leg requirements are practically the same as those called for under 'Choosing the Male Jird,' making lue allowance for sex."

"îhe body should be broad, deep, well filled out and medium large for the variety. The breast should be broad, full and well meated; the back should be broad and the tail well spread at the base. IVry tails, crooked backs or keels, or pinched tails should disyualify for the breerling pen. The abdomen should be well carried and rather full, but should not 'bag down.". 


\section{CHAP'TER II.}

\section{POLLTRY HYGIFNE.}

Seconcl in importance only to high constitutional vigor and health is attention to the basic rules of hygiene and sanitation in the management of poultry. In view of the prevalent misunclerstanding or lack of mulerstanding of these principles it seems wise to devote one chapter to an outline of the more important points which neel to be looked after in hygienic poultry keeping. Attention to the rules and principles here set forth will go a great ways towards preventing the occurrence of discase. This does not mean that if these rules are not followed discase and destruction will forthwith result. Everyone knows of plenty of instances of more or less successful poultry keeping under the most insanitary and mhygienic of conditions. So similarly human beings are able when forced to do so to live under unhygienic conditions. Int every civilized country in the worlel believes that the most economical insurance against the steady loss of national wealth which the prevalence of disease involves is the enforement of sanitary regulations throughout its domain. Again, many men who do not carry fire insurance on their buildings go through life without having any of them burn town. Fut this is no argument against the fact that it is a sound econonic policy to carry fire insurance. In poutry kecping many may be successful for a time in managing their loirts in defiance of the laws of sanitation and hygiene: a e'ery fea may be successful in this practice for a long tince, but in the long run the vast majority will find that thorough. careful, and intelligent attention to these laws will be one of the best guarantees of permanent sticcess that they can find.

I'oultry hygience and sanitation will be consirfered here under 7 main heads, as follows: I. Housing. 2. Feeding. 3. The Lancl. +. Exercise. 5. External Parasites. 6. Disposal of the Dearl. 7 . Isolation of Sickness. What is sairl muler all of these hearls is intencled to apply (unless a specific statement to the contrary is made) both to adult birds and to chicks. No 
di-cusion of the hygiene of inculation, or of the relative merits of artificially and naturally hatched chickens will be undertaken here, hecause there are special subjects falling outside the field of exencral poultry hegiene.

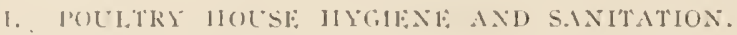

1. Cliculiniss.-'llhe thing of paramount importance in the hygienic lousing of poultry is cleanliness. By this is meant not merely plain, ordinary cleaning up, in the houscwife sense, but also bacteriological cleaning up; that is, disinfection. All buildings or structures of whatever kind in which poultry are housed during any part of their lives should be subjected to a most thorough and searching cleaning and disinfection-at least once every year. 'This cleaning up should naturally conc for each different structure (i. c., laying, colony or brooder house, indiviclual brooler, incubator, etc.) at a time which just precedes the putting of new stock into this structure.

Hoa to dian a poultry housc: Not every poultryman of experience even, knows how really to clean up a poultry house. The first thing to do is to remore all the litter and loose clirt which ean be shovelled out. Then give the house-floor, walls and ceiling - a thorough sweeping and showel ont the accumnlated debris. Then play a garden hose, with the maximum water pressure which can be obtained, upon floor, roosting boards. walls and ceiling, wntil all the dirt which washes down easily is dispoced of. Then take a heavy hoe or roost board scraper and proceed to serape the floor and roosting boards. clean of the trampled, and caked dressing and dirt. Then shovel out what has been accumnlated and get the hose into action once more and wash the whole place down again thoroughly and follow this with another scraping. With a stiff bristled broon thoroughly serub walls, floors, nest boxes, roost boards, ete. Then after another rinsing down and cleaning out of accumulated dirt, let the house dry ont for a day or two. Then make a searching inspection to see if any dirt can be discovered. If so apply the appropriate treatment as outlined above. If, however, everything appears to be clean, the time has come to make it really clean hy disinfection. To do this it is necessary to spray or thorumghly wash with a scrub brush wet in the solution used all parts of the house with a good disinfectant at least taice, allowing time between for it to clry. For this prrpose 3 per cent 
cresol solution is recommencled. 'l'he chicf thing is to trise an effective lisinfectant and plenty of it, ancl apply it at least twice. A discussion of disinfectants immediately follows this section. To complete the cleaning of the house, after the second spraying of disinfectant is diy apply a liquidel lice killer (made by putting 1 part crucle carbolic acid or cresol with 3 parts kerosene) liberally to nests and roxsts and nearlyy walls. After all this is fone the honse will be clem. In honses cleaned anmally in this way the first step is taken towards hygienic poultry keeping.

'the same principles which have been here brotghlit out should be applied in cleaning broolers, brooker houses, and other things on the plant with which the birds conne in contact.

What has been said has reference primatily to the annual or semi-annual cleaning. It should not be nunlerstoon by this that no cleaning is to be done at any other time. On the contrary the rule shomlal be to keep the potultry house clean at all times. never allowing filth of any kind to accumulate and 11sing plenty of disinfectant.

Disinfertion.--In the matter of disinfection there are several options open to the poultryman. Te may make his own disinfectant, or he may purchase proprietary componuds like Zenoleum. Carlulincum or a host of other "enms" which confrout him at erery turn in his reading of poultry periodicals, or he may buy a plain disinfectant like furmalehyle, or carbolic acicl.

The Experiment station has tried various disinfectants with a riew to finding the most nseful, when the factors of efficiency, ease of application and low cost, are considered. 'There is probably no more effective disinfectant than formaldehycle, but after trying it out it was necessary to abandon it as a yeneral poultry house disinfectant. The difficulty was that a man condel not stand the fumes long enough to spray and scrub out thoronghly a pen. Formaldehyele is very gool where it can be nsed. and there is no cheaper disinfectant, efficiency considered. I) 1 . P. 'I. Woods has recently allocated the formaldehyle gas methor for disinfecting poultry houses, nsing the permanganate method of generating. This, however, is indicated only for romens which can easily he closed n1) air tight. It costs two much in time and trouble to make any form of "fresh air" pentery honse even moderately air tight. The formalehyele gas methor is well arlapted to disinfecting and fumbsating feed roums. incuba- 
tor cellars. brooker houses and all houses which can be readily marle air tight. For the benefit of those who wish to use the method for such purposes the following directions are given. This will give a rery strong funigation and disinfection but such is inclicated about poultry establishments.

"Formaldelyde Gas Disinfection: First make the room as tight as possible ly stopping cracks, key-holes, etc., with pieces of cloth or sinilar substance. Open drawers and cloors of bureans, wardrobes, and closets to allow free access of the gas. Use a metal or earthern dish for a generator, of sufficient size so that the liquid will not spatter or boil over on the floor, since the permanganate will stain. The temperature of the room shonlel not lic below $50^{\circ} \mathrm{F}$. and more effective disinfection will be obtained if the temperature is $80^{\circ} \mathrm{F}$. or above at the beginning. Sprinkle boiling water on the floor or place a liettle of boiling water in the room to create a moist atmosphere. Spread the permanganate evenly over the bottom of the dish and quickly pour in the formaldehyde (fo per cent strength as purchased). Leave and tightly close the room at once and allow to remain closed for $f^{-6}$ hours or longer, then air thoroughly." Use 23 ounces of permanganate and 3 pints of formaldelyde to cach 1000 cubic fect of space.

For general disinfectant purposes about a poultry plant the Station has found the cheapest and most effective disinfectant to be compound cresol solution. This is used here for spraying and disinfecting the houses after they are cleaned, disinfecting brooders, brooder houses, incubators. nests and everything else abont the plant which can be disinfected with a liquid substance. Any person can easily make this disinfectant. The following revised rirections for its manufacture are quoted from Bulletin I 79 of this Station.

Cresol Disinfectunt.-W'he actire base of cresol soap disinfecting solution is commercial cresol. This is a thick, sirupy fluid varying in color in different lots from a nearly colorless fluid to a dark brown. It does not mix readily with water, and, therefore, in order to make satisfactory a dilute solution, it is necessary first to incorporate the cresol with some substance like soap which will mix with water and will cary the cresol over into the mixture. The commercial cresol as it is obtained, is a corrosive substance, being in this respect not unlike carbolic acid. 
It should, of course, be handled with great care and the pure cresol should not be allowed to come in contact with the skin. If it does so accidentally the spot should be immediately washed off with plenty of clean water. The price of commercial cresol varies with the clrng market. It can be obtained throngh any druggist. On the day that this was written the quotation on cresol in the New York market is $2+$ cents per pound. In p11rchasing this article one should order simply "commercial cresol."

Measure out 3 I-5 quarts of raw linseed oil in a 4 or 5 gallon stone crock: then weigh ont in a dish I $\mathrm{lb} .6 \mathrm{oz}$. of commercial lye or "Babbit's potash." Dissolve this lye in as little water as will completely dissolve it. Start with $1 / 2$ pint of water, and if this will not dissolve all the lye, add more water slowly. Let this stand for at least 3 homr's mintil the lye is completely dissolverl and the solution is cold; then arld the cold lye solution very slow1y. to the linseed oil, stirring constantly. Not less than 5 minntes: should be taken for the adding of this solntion of lye to the oil. After the lye is added continue the stirring until the mixture is: in the condition and has the textnre of a smooth homogeneons liquirl soap. This onght not to take more than a half hour. Then while the soap is in this liquid state. and before it has a chance to harden add, with constant stirring. $8 \mathrm{I} / 2$ quarts of commercial cresol. The cresol will blend perfectly with the soap solution and make a clear, dark brown fluid. The resulting solution will mix in any proportion with water and yield a clear solution.

Cresol soap is an extrencly powerful disinfectant. In the Station pontry plant for general purposes of disinfecting the houses, brooder houses, incubators, nests, and other wood work. it should be used in a 3 per cent solution with water. Two or 3 tablespoons full of the cresol soap to each gallon of water will make a satisfactory solution. This solution may be applierl through any kind of spray pump or with a brush. Being al clear watery fluid it can be used in any spray pump withont difficulty. For rlisinfecting brooders or incubators which there is reason to believe have been particularly liable to infection with the germs of white diarrhea or other diseases the cresol may be used in double the strength given above and applied with a scrub brush in addition to the spray. 


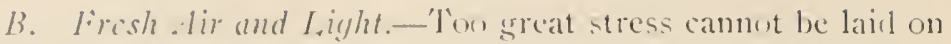
the importance of plenty of fresh are in the poultry house if the birds are to keep in goos condition. Ans it must be rementbered in thin connection that "iresh" air, and cold stagnant air are two very different things. Ton many of the types of curtain front and se-called "fresh air" houses now in we are withont any prevision other than an obliging southerly wind, to insure the circulation or changing of air within the house. Eren with an open front house it is wise to provide for a circulation of air in such way that direct drafts cannot strike the bircls. Thi applie's not only to the housing of atult birds in laying honses. but also to the case of young stock in colony houses on the range.* Further a circulation of fresh air under the hover in artificial rearing is greatly to be desired and will have a marked effect on the health and vigor of the chicks.

Not only slould the poultry house be such as to furnish plenty of fresh air, lout it should also be light. The prime importance of smulight in samitation is muversally recognized by medical authorities. Discase germs cannot stand prolonged exposure to the direct rays of the sum. Sunlight is Nature's great disinfectant. Its importance is no less in poultry than in human sanitation. The following statement made some years ago (I9O4) by a writer signing himself " $\mathrm{M}$ " in Farm Poultry (Vol. I5) brings lome in a few words the importance of having plenty of light in the poultry house.

"Light in the poultry house has been found by a writer a great help in kecping the house clcan and keeping the forts healthy'. I'robably there is no greater assistance to the diseases of poultry than dark and damp houses, and dark houses are frequently damp). In recent years I have had both. kinds of (xperience, those with the hens confmed in a large, dry and light house, and with hens confined in a dark house in which a single window looking towards the setting sum furnished the only light. Being forced to use the latter building for an entire winter I found it impossible to get it thoroughly dried out after a rain had rendered the walls lamp. By spring some of the fowls that had been confined there began to die of a mysterions

\footnotetext{
* See in this connection the modification of the Maine Siation colony house to insure circulation of air, as giren in U. S. Dept. Agr. Farmers' Bulletin 357.
} 
disease and a pust-mortem examination showed it to he liver disease. Later the roup broke out in the same house and this dread disease continued with the flock for months exacting a heary toll in laying hens."

(. Lioid lampness. Of all untarorable envirommental conclitions into which poultry may, by bad management. be brought, a lan1p louse is probably the worst. Nuthing will diminish the prorluctivity of a flock so quickly and surely as will clampmess in the honse, and unthing is so certain an: speely an excitant to roup and kindred ills. 'The place ahere poultry' are housed must be kept dry if the flock is to be productiac and frec from discasc.

D. Prozide Clean and Pry Litter. Experience has demmstrated that the best way in which to give fowls exercise during the winter months in which, in northern climates at least, they must he housed the greater part if not all of the time, is by jorovicling a deep litter in which the birds scratch for their try grain ration. For this litter the Experiment Station uses pine planer shavings. With a layer of straw on top. Whatever the litter it should be changed as often as it gets (lamp or dirty.

\section{HYGIENIC FEEDING.}

Along with housing as a prime factor in ponltry sanitation goes feeding. This is not the place to enter 11 pen a detailed disenssion of the compounding of rations and such topics but there are certain basic principles of hygienic feeding which must always be lonkerl after if one is to avoid diseases. There are:

1. Purity. It should be a rule of every poultrynan never to feel any material which is not clean and wholesome. Musty and mouldy grain, tainted meat scraps or cut bone, table scraps which have spoiled, and decayed fruits or regetables shmel never be ferl. If this consideration were always kept in mind many cases of undiagnosed sickness and reathis and how condition in the stock woulsl be avoiderl. Keep all utensils in which forl is placed clinn.

B. Aroid Oierficaling. Intensive poultry keeping involves of necesity heary feecling, but one should constantly he on the lonkout to gruard against orerfeeding. Which puts the hirel into a state of lowered vitality in which its natural puwer- wf resistance to all forms of infections and other diseases are resluced. The feeding of high protein oncentrate like lineed or 
cotton secd meal needs to be particularly carefully watched in this respect.

C. Prozide Plenty of Grecn Food. Under natural conditions poultry are free caters of green grass and other plants. Such green food supplies a lefinite need in metabolism, the place of which can be taken by no other sort of food material. It is not enough merely to supply succulcnec in the ration. Fowls need a certain amount of succulent food, but they also need fresit groon food. The Station has found green sprouted oats, when properly prepared, to be an excellent source of winter green food. Finll dircctions for sprouting oats are given in Bulletin 179 of the Maine Station, a copy of which may be had upon application to the Director of the Station.

D. Prozide Fresh and Clcan Drinking IVater. The most sure and rapid method by which infections diseases of all kinds are transmitted through a flock of birds is by means of the water pail from which they all drink in common. Furthermore the water itself may come from a contaminated source and be the origin of infection to the flock. Finally it is difficult to derise any satisfactory drinking fountain in which the water is unt liable to contamination from litter, manure, etc. All these considerations indicate the advisability of adding to all drinking water which is given to poultry some substance which shall act as a harmless antiseptic. The best of all such substances yet discovered for use with poultry is potassium permanganate. 'This is a clark reddish-purple crystalline substance which can be bought of any druggist. It ought never to cost more than 2OC-3OC per pound and a pound will last for a long time. It should be used in the following way: In the bottom of a large mouthed jar, bottle or can, put a layer of potassium permanganate crystals an inch thick. Fill up the receptacle with water. This water will dissolve all of the erystals that it is able to. This will make a stock saturated solution. Is this solution is lised add more water and more crystals as needed, always aiming to keep a layer of undissolved crystals at the bottom. Keep a dish of stock solution like this alongside the faucet or pump where the water is drawn for the poultry. Whoncocr any acater is dracon for cither chicks or adult fouls add cnough of the, stock solution to give the water a rather decp wine color. This means I to 2 teaspoons of the stock solution to to quarts of 
water. At the same time one shotld clean and clisinfect the drinking pails and fountains regularly, just as he would if he were not using potasium permanganate. At the Station plant for some 2 years past no birch has ever lasi a drink of water from the time it was hatched which dicl not contain potassium permanganate. except stich water as it got from mud puddles and the like.

Dr. (. B. Norse. the well known authority on poultry diseases of the Department of Agriculture, had the following to say regarding this point in a recent arldress (Rel. Ponlt. Jour. Oct. 1910\%. After describing the potassium permanganate method. as well as two others, directed to the same end, but in the opinion of the present writers not so desirable as this, he goes on to say: "Water-borne diseases are frequent in the ponltry yarel. Clean and disinfect your drinking-fountains (and ron must) ever so well. if you are permitting. conscionsly or unwittingly, to rm at large one bird sick with any of the contagious discases of the head parts or with bowel diseases, you may cotnt on that water supply being contaninated in less than wne hour's time. In the ease of a large flock affected with flagellate diarthoea I have myelf found the flagellates in less than nne lon ${ }^{\circ}$ s time in the drinking water which had been sterilized and placed in thoroughly disinfected fountains. Do you not see where such a conclition as this fores you? Right up against the principle of the incliviclual drinking cup. Risliculots. (h) you say? Not a bit. I did not say the individual drinking cup, 'but the 'principle of the individual drinking cup.' Boark of health are recognizing that by means of the common, public drinking-cup foul and terrible diseases are being spread anong people. It is just so with your poultry, and while you cannot adopt the indivilual cip you can incerporate the principle of it in yotre hygicnic methods by adding * * * * * one of the antiseptics namerl. It is true, in the proportions namerl. these remedies do not disinfect the water. only act as antiseptic. that is, act to hinder the developement of bacteria and other microbes. The water itself should be changed frequently. This hindering of microbian growth occurs not only in the fountain but is kept up in the intestinal tract." 


\section{THE 1,AND.}

One of the nost important considerations in poultry sanitation is to keep the ground on which the birds are to live both as chicks and as adults from becoming foul and contaminated. This is not a very difficult thing to do if one has enough land and practices a definite and systematic crop rotation in which poultry form one element. On the open range where chicks are raised a 3 year rotation is entirely feasible and serves its purpose well. Such a system of cropping would be something as follows: First year, chickens; second year, a hoed crop. like beets. cabbage, mangels or corn, the ground to be seeled down to timothy and clover after the crop is taken off; third year, in grass; fourtl year, chickens again. Other cropping systems to serve the same purpose can easily be levised.

To maintain the runs connected with a permanent poultry house where adult birds are kept in a sweet and clean condition is a more difficult problem. Abont the best that one can do here is to arrange alternate sets of rums so that one set may be used one year and the other set the next, purifying the soil so far as may be by plowing and harrowing thoroughly annually, and planting exhaustive crops. Failing the possibility of alternating in this way, disinfection and frequent plowing are the only resources left.

The following excellent advice on this subject is given by the English poultry expert Mr. E. T. Brown (Farm Poultry, Vol. I8, p. 294): "Tainted gronnd is responsible for many of the diseases from which fowls suffer, and yet it is a question that rarely receives the attention it deserves. The chief danger of tainted soil arises when fowls are kept in confinement, but still we often find that even with those at liberty the land over which they are rumning is far from pure. So long as the grass can be kept growing strongly and vigorously there is small fear of foul ground, as the growth absorbs the manure; it is when the grass becomes worn away that the chief danger arises. The manure constantly falling upon the same small area, and there being nothing to use it up, the land is bound in a short space of time to become so permeated as to be thoroughly unfit for fowls. The question is very often asked in connection with this subject as to how many fowls a certain sized piece of land will acconmodate the whole year through. Occasionally one may see in 
some of the agricultural or poultry journals this question answered, but as a matter of fact to give any stated number is nonst mislearling. It depends very largely upon the class of soil, as some can carry twice as many birds as others; it repends npon the breed of poultry. some being much more active than others. and thus requiring more space; it depends, too, upon the time of year. because during the spring and summer. when there is an abundance of regetable growth in the soil, a considerably larger number of birds can be maintained than during the autumn or winter. 'The number must be varied according to these ciremustances, and no hard and fast rule is applicable."

"The results of tainted ground are generally quickly noticeable, as the fowls have a sickly appearance, the feathers lose their brilliant lustre, and the wings begin to droop. Roup, gapes, and other ailments speedily show themselves, causing, if not leath itself, considerable loss and unpleasantness. One of the greatest adrantages to be derived from portable hnuses is that they so greatly reduce the risk of tainted ground, as they are being constantly moved from one place to another, thus evenly distributing the manure. When it is remembered that each adult fowl drops nearly a hundred weight of manure in the comse of a year, the importance of this question will be immediately realized. It is quite possible, however. provided that suitable precautions are taken, to keep a comparatively small run pure for a long time. If the grass is short it should be occasionally swept, in this manner remoring a good deal of the manure. Another important point is to always have around the house a space of gravel. upon which the birds should be fed, and if swept nuce or twice a week this will have a wonderful effect in preserving the purity of the grass portion. Anyone who has observed poultry will know how fond they are of constantly being near the house, and thus the greater portion of their droppings falls within its immediate vicinity. The shape of the run also has a great bearing upon the length of time it will remain untainted, a long narrow run being much superior to a square one. I have proved by my own experience how true this is, and probably a long and narrow run, containing the same amount of space will remain pure twice as long. It is unnecessary here to go into a full explanation of why this is so, but I may state the fact, which I am confident is quite correct. If the space at one's clisposal 
in rery liniter it is a gaoud plan to divide it into two equal parth. placings the honse in the micllle. During one year one-half womld te avaliable for the fowls, the other being planted with sone guickly growing vegetables, the orter being reversecl the vear following. The regetable growth has the effect of quickly insing 11] the nuanure, and in this manner quite a small plot of land can be hearily stocked with ponltry for an unlinited number of rears. If the soil becomes at all foul it is a goorl plan to water it with a 1 per cent solution of sulphuric acid. or to apply a light dressing of gas lime."

\section{EXIERCISE.}

If poultry are to be in good comelition, and maintain their 1urmal resistance to disease they must erercise. As chicks they will do this on the range. As adults (in climates like that of Naine, the most feasible way to bring this about is to provicle litter and make the bircls seratch for their feed.

\section{EATERNAL, PARASITES.}

In hygienic poultry keeping the birds must be kept reasonably free at all times of lice, mites, and all other forms of external parasites. Directions for dealing with this matter are given in retail farther on in this book in the chapter on External Parasites. It is desired here merely to call attention to the matter as one of the general principles of hygienic ponltry management.

\section{DISIOSAI, OF DEAD BIRDS.}

The ponltry plant which dues not have some dead birds to dispose of from time to time has yet to be started. Inst in connection with the disposal of such clearl birds is one of the weakest points in poultry sanitation as too commonly practicerl. The number of poultry keepers who throw dead birds on the manure pile or ont on a temporary unused field is much too large. This is a short sighted ant dangerous procelure. Anyone who contintes for a long enough time to dispose of his dead bircts in such a way is tolerably sure, sooner or later. to be wiperl out of husines ly an epidemic. with a thoroughness and clespatch which will leave him wondering what in the world has happened.

The most sanitary method of disposal of clearl bodies is cremation. Wherever it is possible erery ciead bird should be burned 
just as sorn as may he after death has oceurred. In many casehowever, a farmer or poultryman is not so situaterl as to be able to burn elead animals without too great an expenditure of time or labor. In this event burial is about the only alternative, ant here, as in the song. it is wise to dig the grave "both wide and deep," especially deep. Otherwise. through the aid of foxes. clogs. skunks, or other creatures, the dearl may "rise again" in a literal and most insanitary manner.

\section{ISOLATHON OF SICKNTSS.}

Whether one expects to treat the bird or to kill it, coery indiridual that shon's signs of sickness should be removed from the sencrul flock. When the bird has been isolated a decision as to what will be done about the case can be reacher at leisure, and in the meantime the flock is not subjected to the langer of infection. This is an important matter with young chickens as well as with adult stock.

\section{The Essextills Of Polltri Hygiene.}

To summarize this discussion of poultry hygiene and sanitation it may be said that the essentials in the hrgienic and sanitary management of poultry are

\section{Clean Houses.}

2. Clean Air.

3. Clean Food.

4. Clean Water.

5. Clean Yards and Clean Range.

6. Clean Incubators and BRoOders.

7. Clean Birds, Outside and INSIde. 


\section{CHAP'TER III.}

Tine Diagnosis of the Diseases of POUltri.

The first thing that the poultry keeper whose hirds are ill wants to know is: "What ails my chickens?" Before he can use this or any other book on poultry diseases effectively in getting advice for the treatment of disease he must diagnose the trouble. It is the purpose of this chapter to help him do this, and in this way make this book more useful to the practical poultryman. At the outstart it should be said that the absolutcly certain differential diagnosis of particular discases of poultry, by the farmer or poultryman, cither on the basis of cortcrial symptoms or post-mortem cramination is in nearly "iery casc impossible. The best that can be done practically is to determine into ahat gencral class of discases a particular trouble falls.

There are two general sources of information upon which to base a diagnosis of clisease. These are:

I. External symptoms.

II. Post-mortem examination.

EXTERNAL SYMPTOMS, WITII A TABLE TO AID IN THE IDENTIFICATION OF THE CIILF CLASSES OF POUI,TRY DISEASES.

There are certain external symptoms which are characteristic in a way of nearly all diseases. These symptoms merely indicate that the bircl is sick; they are of no ialuc for purposes of differential diagnosis.

'These general symptoms of illness may be described as follows: A sick fowl is usually quict, and does not move about unless disturbed. It stands or sits with the neck contracted so that the head is pulled well in to the body, giving the bird a "humperl up" appearance. The eyes are often closed, entirely or partly, giving the birel a sleepy appearance. Often the feathers are roughened and stick out all over the body. The comb and wattles may be dark or, on the other hand, may be rery pale. 
When a hird shows these general symptoms of illness it should be picked up and isolated and an effort made to obtain a more precise diagnosis. In doing this the following table of the chief external simptoms may be found of use.

This tahle aims to direct one to the discussion of general classis of disease. The identification of special individual diseases should be attempted only after reading over the chapters covering the general class involved. In general it should be kept in mind that this table is not intended to tell the readen what the discase hi finds is, but solely to tell him what parts of this book to read in any giren case in order to make a diagnosis.

Table of External Symptoms ahich may be of Some Value in Differential Diagnosis.

The numbers in brackets denote the puges to be consulted.

$-y$ - YPTOM.

Diseases which the symptom named may indicate.

\footnotetext{
Abdemen swollen ........ Peritonitis (i2). Dropsg (73), White diarrher (181).

Belehin! of gas........... Intlagımation of ('roj) (34).

firenthing abnormal (i. c.). Iniseuses of the respiratory system (85).

(ow) raviol, too slow, whe'e\% Arsenic poisoning (44), Pericarditis (112).

ing. Whistling. snoring or tiapes (195), Air-sac nite (110).

in any lifterent from nor-

mal.....................

(\%okin!f................ Arsenic poisoning (44).

Cimmb, pule............. Tubereulosis (5i). Jropsy (73), Air-sae mite (110).

Infectious leuketnia (t14), II hite diarrhea (181).

roml, first [nte, but later Enteritis (39).

rlusk...................

ruml, very durk......... I.iver disease (4i). liackhead (53).

('ongestion of lungs, (10ت), P’urumonia (108).

romb. gellow............ Liver discanes (47), Visceral gom (121).

rumb, with white, fuwdery White eomb (150).

(elurt.....................

('onstiputim............ Simple constipation (-11), Indigestion(12),

Intlamuation of writuet (165).

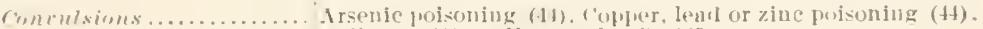
Epilensy (119), "llarvat-bug" (115).

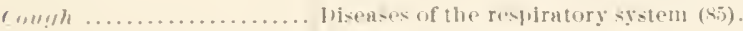

roup. entarged and hard... ('ros, bound (32).

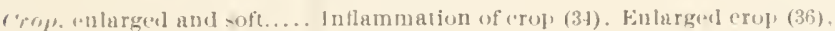

frastritis (36).

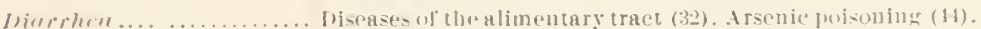

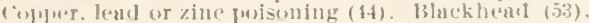

Tulerenlosio (57), rhotera (66). linule (90).

White rliarrhen (181).

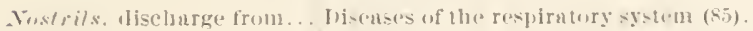

Fincrivtion Tuberculuis (5i). Inpergillosis (114). Vkeral genat (121) Itite- (132). White illarrica (1s1)
} 


\section{Tabli of E.rtermal Simptoms-Concluded.}

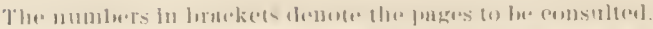

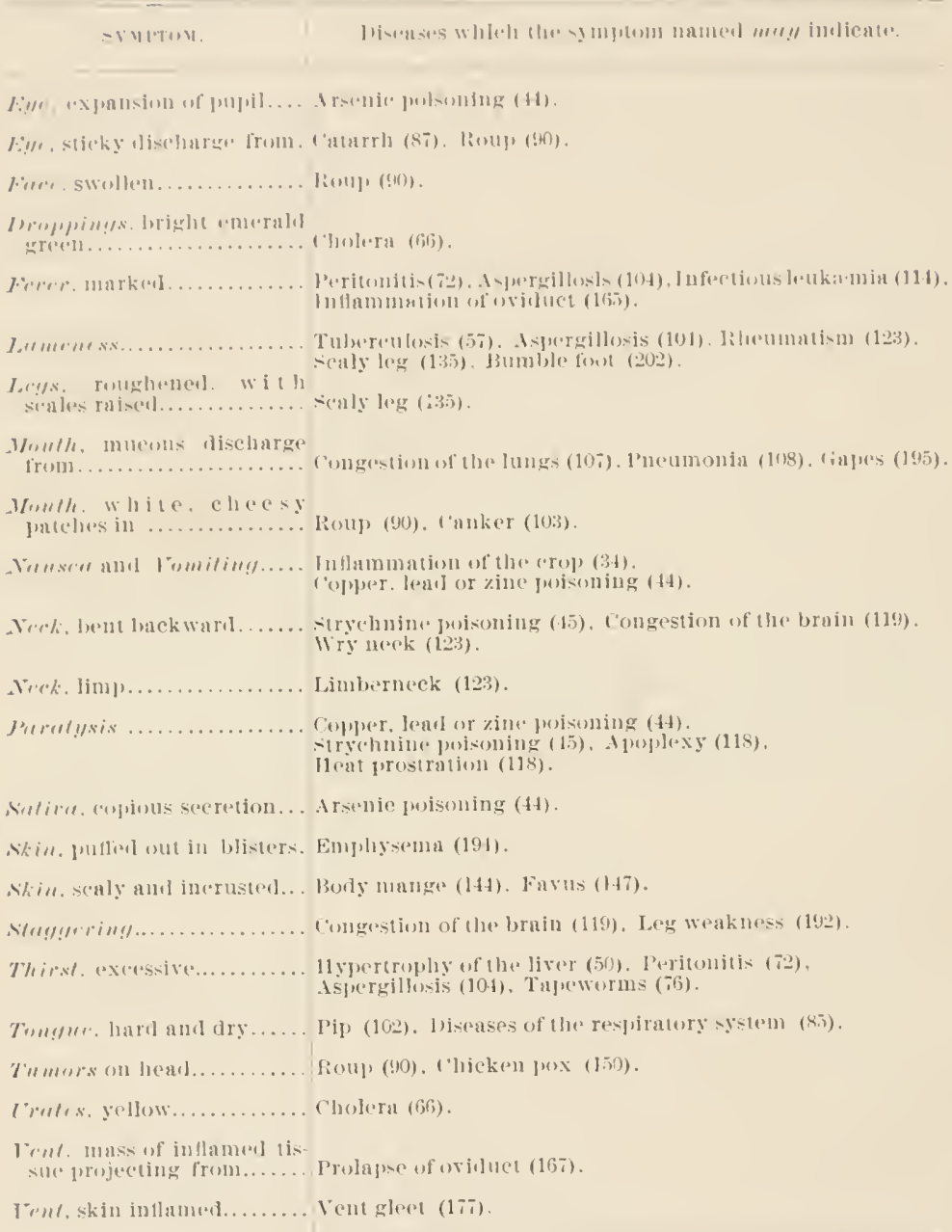

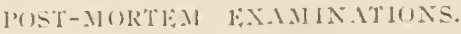

Whencere a bircl dies from a canse not entirely clear to the penltryman a pust-mortem examination should be made in order to learn, if possible, from the conclition of the internal organs what it was that cansed death. The poultryman should familiarize hinself with the appearance of the internal organs in a nor- 
mal state of health. so that be may at once recognize any cleparture irom these normal conditions.

The following directions and general artice regarling the making up of atutopsies is taken from the English pottloy jour11:al "Poultry" :

"Hon'to make a post-mortin cramination, so that these iarious oryans can bi sien and ciramined, and so that a generaí opinion ian be formed as to their condition of halth or otheraisi. Let it be understood that a very large number of poultry which dic ate rictins of sme entirely simple complaint. such as enlaregenent of the livere or tuberetrlosis in the lungs. These complaints are casily reougnizable, and there is no reason at all why ans famer of amatem potulty keeper shomld not be able to form a sencral opinion as to whether his poultry are dying off from some such complaint as one or other of these. Take the dearl bird and lay it on a wooden table or on a piece of strong board. breast mppermost. Spread ont the wings and the legs. putting a small nail through the joint of each wing and through the center of each foot. It is not necessary for the birel to be entirely plucked : it will be enough to pluck the breast. and when this has been dome pinch up the skin at the point of the breast bone, and cut it straight throtigh from the vent to the crop. Haring donc this, dram back the skin on both sicles so as to leare the flesh fully exposed, and then with a sharj knife ent through the Hesh on buth sieles of the breast bone, and with a strong. blunt pointerl pair of seissors. cut ont the center of the breast bone sutirely. taking particular care in loing so not to injure the heart. as a How of blond from the heart will interiere with subseruent operations. When this has been done the principal organs will be seen clearly exposed."

"First wif all examine the liver. 'lis he perfectly healthy. it should lx of a rich cheolate brown color. free from any s]ecks. and free from any disenlonation (althotigh there are sometimes pest-1mortem discolorations at the celges. which are easily recesnizable). If the liver contains any specks it is monealthy, as

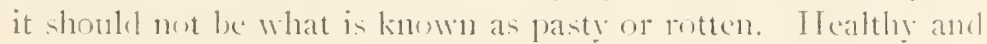
firme to the wuch and of the proper color. is the general deseription to apply to the liver. The heart shombl then be lusliesl at.

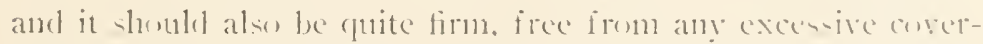
ing of fat. and alse quite free from little no lules af tuberent- 
losis. Another thing about the heart is that it should be even loberl-that is to say, it should not be distended on one side and emuty on the other: if it be so, the probability is that the bird has died from heart failure, and supposing it is known that the biril dicl die suddenly, this can at once be accepted as the causesyncupe, failure of the heart's action, which always ends in very sulden death, the birel simply dropping down dead without any warning. 'The lungs, which will be seen on either side at the lack of the heart, are spongy looking bodies of a pink color. If a piece of one of the lungs can be cut off and be placed in a bowl of water it should float. not sink. or it will be unhealthy. Always look at the lungs for tuberculosis, which is usually to be detected there.* and is indicated by little cheesy nodules in the substance of the lungs. which cannot possibly be mistaken; sometimes the lungs and the heart will all be eaten by these tuberculous masies. If no disease las been found so far, proceed to examine the crop and the gullet. also the windpipe. With regarel to the crop. it might almost be examined first if $i t$ is full of food, and apparently in a state of congestion, to see whether there be a stoppage in the opening from the crop to the proventricle. The gullet and windpipe can also be examined to see if there is anything mulealty about them. Similarly an examination can then be macle of the intestines. and in the case of a hen the egg organs can be carefully dissected to see whether there is a broken egg. or whether any egg substance has escaped into the carity of the abdomen and set up inflammation."

"There is no difficulty about making an examination of the skull, and the amateur with a little practice will rery easily be ab) to to this. The way to set about it is to start at one corner of the mouth, and with a pair of sharp pointed scissors cut aromnd the skull to the other comer of the month; it will then be quite an easy matter to lift up the skull from the back, and the brain will be clearly seen. This shonld be perfectly clear, and if there be any trace of a slight effusion of blood, it will be po-itive eridence of an apoplectic seizure, and will confirm the simptoms of apoplexy, which are delirium, resulting, after a few hours or a few days helplessness, in death. These, then, are

* This is usually not the case (see below p. 62). This writer has probably mistaken aspergillosis lecions of the lungs for those of iuberculosis. Note added by compiler. 
the principal points, and any amateur can make a simple matterof-fact examination such as has been described, very often with considerable satisfaction to himself."

In order to get the benefit of the descriptions given in this book of the post-mortem appearances of organs in varions cliseases, the poultryman should proceed as follows. If the liver, for example, of a dead bird appears to be abnormal, look up in the inclex of this book the entry "Post-mortcm appearance of." Under this will be found a heading "liver," followerl by the page numbers $40,47,49$ to 56,6 I, 68, II3, II5, I2I, I88, I94. This means that on each one of the pages listed will be found a description of the post-mortem condition of the liver in a bird dying of some particular disease. Similar entries are made for other organs. In this way the post-mortem examination may be made to aid directly and quickly in the diagnosis of discase. 


\section{Pothitre Materha Medica.}

It is the purpose of this chapter to give an account of the druse and remerlies which the poultryman will find it well to l.e stuplplerl with; directions for making varions solutions; tables of weights and measures and the like.

\section{MEDICINE CIIEST.}

The following drugs and medicines will be found useful to have at hancl.

Calomel (subchloride of mercury).-."This is a very useful alterative medicine for fowls, I grain pills frequently having a good effect on the liver. When given it should be followed in two hours by a dose of castor oil. Some anthorities oppose the nse of mercury in any form for poultry, but there have been mumerous cases when it has produced good results." (Brarlshaw.)

Caycunc.-. Is considered to be an excellent liver stimulant when given in small quantities. In cases of colds it is also nsefull. and forms one of the ingredients in the spices so much used to stimulate winter laying." (Brallswa.)

Catechu.- "In powder or tincture form, in combination with pow lered chalk. is a good remerly for diarrhea. The average cluse of powdered catechu is from 2 to 5 grains, and of the tincture from 2 to 5 (lrops." (Bradshaw.)

Custor oil.- Although apparently paradoxical. this is one of the best remedies for diarloea. The latter is frequently due to some fretid matter in the intentines: a dose of oil will nsually remove this, and often diminish the diarrhea. It is also used in cases of crop-bound fowls. A teaspoonful poured down the throat, and the mass kneaded with the fingers, and then warm water poured clown will of fen the matter, and frequently effect a clire." (brallhaw.)

lipsom solts (magnesimu sulphate).- "Is one of the simplest. cheapest. a:ul wost effective poultry-yad drugs. It is useful in 
liver disease, diarrhea, and many other complaints. Half a teasponful for a full-grown fowl is a standarl duse. It can be mixed in the soft food. but is more effective ly starving the fowl for a few hours, dissolving the salts in warm water, and pouring it down the birl's throat. Fipsom salts always act bert accompanied with a good quantity of water." (Bradshaw.)

The following talle of doses of Epsom salts for young hircls has been worked ont ly Gage and Opperman:

\begin{tabular}{|c|c|c|}
\hline A1,L: wF lisell. & 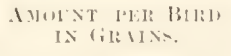 & HoW AMIXITERED. \\
\hline $\begin{array}{l}1 \text { to } 5 \text { weeks } \\
5 \text { to } 10 \text { weeks } . \ldots \ldots \ldots \\
10 \text { to } 15 \text { weeks........ } \\
15 \text { weeks to } 6 \text { momtlis. } \\
6 \text { months lo } 1 \text { your.... } \\
1 \text { year and over....... }\end{array}$ & $\begin{array}{l}10 \text { grains } \\
15 \text { grains } \\
20 \text { gruins } \\
30 \text { grains } \\
35 \text { grains } \\
10-50 \text { grains }\end{array}$ & 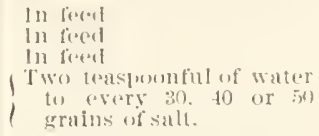 \\
\hline
\end{tabular}

Cotton Secd Oil.-"Olive and salad oils are nseful when hens are egr-bumd, for diarthea, and also for external use in dressing torn combs and other wonnds. In ere tronbles it takes the place of a simple lotion." (Pradshaw.)

Bichloride of mercury. I to Iooo solution.-To make this the simplest way is to buy of the druggist bichloride of merenry tablets, and ask him to label the box to show how much water a tablet must be disishled in to make a 1 to 1000 solution. If one desires to mix it up for himself ask the druggist to make i1) some $I$ gram (15 T/2 grain) powders of lichloricle of mercury. Dissolve I of these powelers in a quart of water. l'ut in enough lamndry bluing so that the color will be deep blue. Then the solution, which is highly poisonous, will never be mistaken for water.

"I to 1000 bichloride" is a germicide and disinfectant for external nse, cleansing womeis and the like.

Medicines in Tublet Form. Cone of the must convenient forms in which medicines may be administeres is in tablets. Wholesale and mail-order drug houses carry extensive lines of these graded as to dosage. They may be arlministered to poultry very easily and conveniently by holding the bircl's mouth open with one hand and with the other thrusting the tablet far enongl lack in the thront so it will be swallowerl.

The following list of tablets will le found useful to the poultryman. They fairly well cover the merlicines recommenterl in 
the boly of this book. Any poultryman may get these either from his local druggist, or if he cannot furnish them, they can be purchased by mail at approximately the prices named from The Frank s. Betz Co., Hammond, Incliana.

Price

per 1000

Salicylic acid, $2 \mathrm{~T} / 2 \mathrm{gr} \ldots \ldots \ldots \ldots \ldots \ldots \ldots$.70

(lior use in rhemmatism.)

Aconite root, I-Io gr.............. .50

(For use in fevers.)

Antiseptic tablets, Bluc, Corrosive sublimate.

7.3 grs.; Ammonimm chloricle. $7.7 \mathrm{gr}$.

I'rice. 35 c. per 100 .

(For making I to Iooo bichloride solution. One tablet dissolved in I pint of water gives a solution of that strength.)

Rismuth subnitrate, I gr............. So

(For intestinal irritation.)

Calomel, $1 / 4$ gr................. to

Iron, Quinine and Strychnine.......... So (For nse as a tonic, dose 3 per day.)

In administering tablets in the manner suggested care should be taken to see that they are swallowed, and not conghed up.

AN ANTISEPTIC OINTAENT FOR LSE ON CUTS AND WOUNDS OF ALL KINDS.

The following ointment may be made up by the poultryman and will be found useful in the treatment of cuts, sores and wounds of all kinds of poultry and stock in general.

Oil of origanum............. I OZ.

Cresol .................

Pine $\operatorname{tar} \ldots \ldots \ldots \ldots \ldots \ldots \ldots \ldots \ldots \ldots \ldots \ldots \ldots \ldots$ I oz.

Resin ................. I oz.

Clcan axle grease $\ldots \ldots \ldots \ldots \ldots \ldots$. 8 oz.

Melt the axle grease and resin and stir in the other ingredients. Pour off in a tin box or can to cool. In making this, clean axle grease from a freshly opened can should be used. 
TAILES OF IPOTHEC.IRIES WEIGHTS IND ME.ISURES AXD THEIR METRIC EQUIVAIENTS.

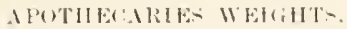

$$
\begin{aligned}
& \text { tomul ounces (Troy) lorelums formples firains dirams. }
\end{aligned}
$$

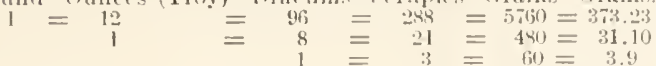

APUTIIETAIES MEASTRE.

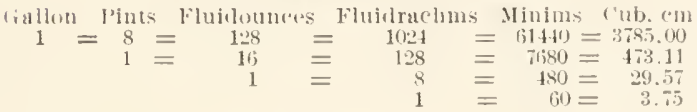

('OMMON MEATIRE.

A fercus is estimated to hold afout f fluidounces, one gill. Ii llineglessis intolitespoun

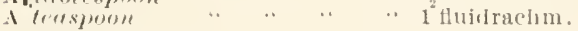




\section{CHAPTIER I.}

\section{DISEASI:S Ol: THF ILIMEXTAR TRACT.}

The arrangement of the digestive organs in birds cliffer from that in other domestic animals $i n$ that the mastication of the foul dees mot take place in the mouth. The food of birds, consisting mainly of grains and seeds, is swallowed whole into the crop. It remains here until it is completely softened by the juices secreted by this organ. The forl then passes into the stonach (proventriculus) where it is mixed with still other juices, and then into the gizzard. The muscular walls of the gizzarl grimel the softened food against the small pebbles (grit) which the bird picks 210 , until it becomes a paste. This paste is then pasiorl into the intestines and mixed with the secretions frum the liver, pancreas and the intestines themselves. The nutritive elements of the food are transferred throngh the intestinal walls, by means of the activity of the cells composing these walls, into the bloot and are carried to various parts of the animal to be userl in building up the tissues.

In the wild state birds are forced to hunt for their own food. They go about gathering in a few seeds here and there but prolially at no time is the crop orerloaded. Under conditions of domestication the bircls are fed only once or twice a day and thus the crop is often gorged with a day's supply of food. Further the lack of sufficient grit, lack of exercise and the feeding of rich, soft mashes cause the bircls to be preclisposed towarkindigestion. Under these conditions poultry are subject to al larese number of disorders of the digestive system.

DISE.LSFS UF THE CROP.

Impactid Crop (Crop Bound).

In general two immediate causes may be given for birds becoming crop bound. ( I) The thin muscular walls may be paralyzerl either through over-alistention with dry grain or through some di-ease, as clolera and diphtheria. (2) The opening into 
the lower portion of the esophagus may become clogged by long straws. feathers or other substances. In either case the crop fails to empty itself while the bird continues to eat until the rop) is greatly distended and packed solicl.

Impacted crop is a common disease of poultry. A large number of things have been assigned as a catise for this tronble. It is probable that the real cause lies in low vitality due to improper feeding and incligestion. On this point Robinson says: "Ne say that the dry hay the fow may take into the crop canses impaction, but the fact is that it is only in occasional instances that it does cause impaction. Far oftener the fowl eats dry hay or corn folder till its crop is bulging, and is never scen to be at all the worse for it. I have seen this so often. that thongh an occasional case of inpacted crop might properly be attributed directly to the orerloading of the crop, the occurrence of a number of such cases in a flock at about the same time, would suggest that the real cause was indigestion, or weak digention. I have repeatedly given fowls, which all their lives had been handled to make and keep digestive organs in first class condition, all other conditions for developing cases of impacted crops, but have never been able to get a case that way."

Treatment.-If a large number of crop bound birds occur in a flock, it shonkl be taken as a sign that something is wrong in the management. Neasures should be taken to correct errors in feeding and thus give the birds a more vigorous digestion. In such epidemics other evidences of indigestion are usually present and the particular treatment of the flock will depend largely on these other symptoms. In general the birds should not be feel too much at any one time and they should be encouraged to take as much exercise as possible, and should have plenty of green food.

When a crop bound bird is found it must be treated indivirlually. 'Treatment in such individual cases is quite often successful. The profitableness of such treatment must be decided by every poultryman for himself. If the crop bound condition is disenvered and treated at the beginning of the trouble the bird will usually recover quickly and may make a profitahle fowl. On the other hand if the condition has become chronic the vitality of the bird is greatly lowered. In this latter case 
is maty recover but it will be a long time before it will repay the owner for his trouble and feed.

If swelled grain is the canse of the impaction the bird may often he successfully treated without an operation. In this case first give the bird a tablespoonful of castor oil. After allowing this a little time to work into the crop begin to knead the hard mass. After this mass has been softened lobld the bird with hearl downward and attempt to work the grain out through the montly. If unsuccessful in this or if the impaction is clue to clogrging with straw or other material it will be necessary to open the crop.

The following method for this operation is griven by Sanborn (Farm Poultry Doctor): "If someone can hold the bird for you it will make the operation easicr. Pluck out a few feathers and then cut through the skin over the crop a line about I inch long. This cut should be in the median line of the body. Then make an incision $3 / 4$ of an inch long through the crop. The (listention of the crop will cause the opening to sape, and the mass will be in plain sight. With toothpicks, blunt pointed scissors, twcezers, or similar tools, take out the contents of the crop. This done run the finger into the crop and make sure that there is nothing remaining to obstruct the outlet to the organ. When sure all is right, take 3 or 4 stitches in the opening in the crop, making each stitch by itself and tying a knot that will not slip. Then (on the same thing to the cut in the skin. For stitches use white silk (or if nothing better can be obtained) common cotton thread, number 60 . Keep the bird by itself for a week, feeding soft foorl."

The above operation is not a difficult one and is usually successful. Care should be exercised to have the hands and instruments thoroughly clean. After the contents of the crop liave leen removed the wound and the empty crop itself should be thoroughly washed out with clean, warm ( $\operatorname{loS}^{\circ}$ to II $^{\circ} \mathrm{F}$.) water. 'The edges of the skin wound should be well greased witls vascline. It is well to feer the bird only milk for the first day or two.

\section{Inflammation of the Crop.}

Inflammation or catarrh of the crop usually accompanies more $n$ less general disturbances of the digestive system. As a result of the irritated condition of the mucous membrane the functions 
of the crop are disturbed or arrested. It is saicl to be catused liy eating indigestible, decayed, or poisonous food. "'Tle foods and substances specially nentionerl as cansing inflammation of the crop are: Decomposed meats and putricl foods of any kind, tnislaked lime, paint skins, rat poison, excessive use of condinents and spices, milled by-prolucts containing too large proportions of hulls or other indigestible fibrous particles. Salmon notes that it may result from the presence of worms in the crop, and that it occurs as a complication with thrush, diphtheria, and cholera. It also oceurs frequently with gastritis." (Robunson.)

Diagnosis.-"The most prominent symptom is distention of the crop, and on examination the swelling is found to be soft and due to accumulated liquid or gas, mixed with more or less foorl. The birds are dull, indisposed to move, and there is belching of gas, loss of appetite and weakness. Sometimes there is nansea and the affected bird attenpts to vomit. I'ressure upon the crop causes the expulsion through the month of liquicl and gas having an offensive odor dne to fermentation." (Salmion.)

Tratmont.-The first step in the treatment of this disease is to empty the crop as completely as possible. This can be lone by lolding the bird head downward and carefully pressing and linealing the crop. After most of the contents have been expelled in this way give the bird several spoonsful of lukewarm water and then empty the crop as before. Cive a slight purgative such as a small teaspoonful of castor oil. 'The bircl shoulil be kept without food for 12 to 20 hours and then fed sparingly on soft, easily digested material. Salmon recommends giving 2 grains of subnitrate of bismuth and $\mathrm{T} / 2$ grain of licarbonate of sola in a teaspoonful of water to relicve irritation and to correct aciclity. Salicylic acil, I grain to an onnce of water, is also recommentecl. 'The dose is 2 to 3 teaspounfuls. Ilill recomments the feeding of mucilagrinons fluids such as barley-water, thin solution of gum, etc. If the inflammation is due to eating poisons anticlotes as given farther on (Chapter VT) should be used.

If inflammation of the crop is at all general throughout the flock an elfort should be made to remove the cause. It is well to change the feed and give the hirels more exercise. The addition of fine charcoal (small chick size) to the masle will ofen be of service, as the bircls eat more of it in this way than when the charcoal is in a box by itself. 


\section{Iinlarged Crop.}

"l'he crop sometimes lecomes very much enlarged and prominent, but langing looscly, not bulging and hard, as in inpaction of the crop. 'This form of permanent enlargenent and displacenient is called culargerl crop, slack crop, or pendulous crop. It may exist with little inconvenience and detriment to the fowl." (Rolinson.)

According to Sanborn the cause of this is irregular feeding resulting in orerloading. Robinson, however, says that while "this may be the cance in a great many cases, yet it can hardly" be the sole caltse, for cases of slack crop are not infrequently found in fowls that have been well and regularly fed. If a fowl is fed heavily, and from any catse (as indigestion) the crop remains full and distended too long, though this condition may in time be relievel in the natural way without interference of the lecper, the effect on the crop is the same as if the overloading had occurred because of irregular feeding. If this condition is repeated several times the walls of the crop become in some degree permanently distended."

An enlarged crop and an enlarged or "baggy" abdomen are frequently associated in the same bird. These are probably due to too heavy feeding withont sufficient intervals between meals and without sufficient exercise.

Treatment.-As stated above, a "baggy" crop often gives little or no apparent inconvenience to the fowl. In the case of a very valuable birel it night be worth while to operate. Samborn states that this clefect can be remedied by cutting ont of the enlarged portion of the crop a diamond or oval shaped picec of tissue about 2 inches long and I inch wide. The edges should be sewerl together and treated as directed for impacted crop. (Cf. p. 34). The general surgical methods described in the chapter on l'oultry Surgery (Chapter XX) should be followed.

\section{DISEASES OF TIEE STOMACII (PROYENTRICLLLS).}

Inflammation of the Stomach-Gastritis.

The stomach or proventriculus in fowls is a rather small organ. It is a thick, slandular walled section of the alimentary canal lying between the crop and the gizzard. Inflammation of this organ is ustally associated with a similar disturbance of the 
crop. In a few cases there appears to be inflammation of the stomach alone. Diagnosis in this case is very difficult.

The cause of gastritis is usually regarded as the same as that of inflanation of the crop (cf. p. 34).

Diagnosis.-In general the symptoms are very similar to those in cases of inflamation of the crop (see p. 34). 'The birds present the general appearance of lecing sick, viz., loss of appetite, indisposition to move and roughness of plumage. Constipation quite often accompanies gastritis. However, if the inflammation extends to the intestines there may be diarrhea.

Treatment. - "If the disease is identified in its early stages, seck for its canse and endeavor to overcome it by removing the canse. Change the ration and give more easily digested food with some meat. Feed regularly, often, and a small quantity at a time. Give some cooked food with harley water or milk for drink, or put 20 grains of bicarbonate of soda to a quart of drinking water. In severe cases give 2 grains of subnitrate of bismutll 3 times a day in a teaspoonful of water. Counteract constipation with Epsom salts (20 grains) or castor oil (one teaspoonful) once a day as long as may be necessary." (Salmon.)

"Give rice water for drink, soft mash made with the water in which clover hay has been cooked. Arsenite of copper, 1/4 grain to each quart of the rice water (drink) will do for medicinal treatment." (Sanborn.)

As Robinson points ont the inportant thing in treating this disease is to change the food in so far at least as to remove the canse of the tromble. Medical treatment withont the removal of the original cause will be of little avail. The adclition of fine (chick size) charcoal to the mash and the generous use of good green foorl are recommended.

DISEASES OI* TIE INTESTINFS.

Simple Diarrhea.

In many fowls a condition of mild diarrhea is chronic throughout the life time of the birel. Again birds often acruire a slight diarrhea which will last for a longer or shorter time, hut never becoming severe. In either of these cases the bird shows no symptoms of disease other than the watery droppings. No doubt such attacks are in some degree detrimental to the best 
health of the bircl. In most cases of this simple diarrhea the bircl will recoser withont any treatment. Nevertheless the careful punltrinan will watch his dropping boards for signs of "lowseness." When snch are found in any equantity the methods of fecding and housing should be carefully exannined to see if the catlse dees not lie in them.

Concerning the normal droppings of fowls, Rolninson says: "Normally the droppings of fowls are rather dry, retain the slape in which they are voided, and may readily he removed, kaving the spot on which they had fallen either slightly stained. or 110 at all."

linther, about $\mathrm{I}-3$ of the normal lroppings consists of a whitisls substance. This is the uric acid and urates cxcreted by the killners and is removed from the cloaca along with the feces.

"Ir ithout marked departure from the normal, droppings may be wet-watery-with a tendency to flatten on the surface on which they rest. On boarls they moisten the surface for some distance aromel them. *** $*$ It is perhaps most appropriately described as "looseness." It is not cliarrhea, though fowls having it are probably more susceptible to intestinal discases than others. Mere looseness of the bowels is not accompanied by any offensive odor.

"When the excrement becomes soft and pasty or liquid in consistency and whitish, yellowish, greenish or brownish in color, and has a more or less marked offensive odlor, the condition is properly described as diarrhea. The evacuations in diarrhea are often of such consistency that the water in them is not readily taken up by absorbents with which they come in contact, and they are deciledly nasty, not only adhering to utensils used in removing them, and making ordinary cleaning difficult, but soiling the feathers of the fowls and sticking to roosts, nests and feed troughs." (Robinson.)

Diarrhea may result simply from an upsetting of the digestive organs due to improper feeling or it may be a symptom of some more serious disease. Simple diarrliea may arise from the presence of indigestible matter in the alimentary canal, it may be due to exposure to heavy rains or to draughts in the roosting house. In the latter cases a cold derelops which affects the bowels rather than the head and lungs. Diarrhea from colds occurs much more frequently than is generally supposed. This 
form of cliarthea can often be recognized by the greater amount of frothy mucus in the excrement. Young stock are much more susceptible to diarrhea from colds than are adult bircls.

Among other common canses of simple diarrhea may be mentioned soured or decomposing food, too much green food at irregular times, too free use of animal food, allowing the birds access to water which has become soiled with excrement and allowed to stand in the hot sm until about putricl. Whatever nua be the inducing factor the immediate cause is excessive bacterial fermentation in the alimentary canal.

Treutment-Simple diarthea will usually require no treatment other than removing the original cause. 'This latter is by far the more important thing to be done. If neglected the condition may become chronic and may result in more serious disturbances of the alimentary system. It is often beneficial to replace part of the bran in the mash with midellings or low grade flour. Where in aldition medical treatment seems desirable the first thing to do is to remove the fermenting material from the intestinal canal. This can be done with Epsom salts, nsing a small half teaspoonful to each birch. This should be dissolved in water and used to mix the mash. If more convenient a teaspoonful of castor oil may be giren eaclu bird. If the diarrhea is persistent 1 iill recommends 3 to 6 drops of chlorodyne as an mnfailing cure.

\section{Entcritis-Dyscutcry.}

For practical purposes we may associate most of the severer forms of diarthea with the above names. Simple diarrhea was defined as either a temporary or chronic affection of the intestines from which the bircl appeared to suffer but little. Practically its only symptom is the watery or discolored discharge. Lnele the names of enteritis, dysentery or severe diarrhea there are listed several of the more serions infections of the intestines. lirom the medical standpoint enteritis is the name given to affections of the small intestines while dysentery is applied to the lisease in the larege intestine. The latter is usually acempanied by mucous and bloody discharges. In the diseases of poultry. however, it is hardly necessary for anyone other than a pathologist to distingtish betwen these different forms.

Eitiology.-. A variety of causes are responsible for these more acute forms of intestinal trouble. It may be a bacterial infec- 
tion coming from filthy conditions. Foul drinking water, putrid meat or decaying food of any sort may be predisposing causes. 'T'oxic enteritis or poisoning is caused by the birds eating such things as paint skins, lye, nnslaked lime, salt, ergot of rye, arsenic and copper (in spraying mixtures) (cf. p. 44). Further simple diarrhea may develop into the more acute form. This latter is due to improper food, water or housing, and is probably closely associated with bacterial enteritis. Varions intcstinal parasites may canse severe diarrhea.

Diagnosis.-It is often very difficult to distinguish between the different infections of the intestines in the living birds. IVoods (Reliable Ponltry Journal) gives the following symptoms of enteritis: "The affected bird is inactive and (lumpish. The comb is at first pale and limp, and later becomes clark and purplish. There is an abundant dark or greenish diarrhea. Diarrhea may become bloody. The bird appears slecpy and unwilling to walk around. The bird may be sick a week or several weeks before death takes place. Some birds recover without treatment. The appetite may be voracious, or the birds may refuse to take food. The crop may be full of food, or may contain only a little slimy fluid. When the bird dies, the comb is always dark. Often the bird may appear dumpish and sleepy, and show a bad diarrhea; the owner, picking the bird (1) to examine it, finds it has lost weight; holding it head downward, a stringy, dirty liquid rums from the mouth, and death of the bird soon follows. In such cases, the bird has been sick several weeks before it was noticed. Examination of the body after death shows the liver enlarged or shrunken, according to the duration of the disease. If of long duration the liver is shrunken. The spleen is usually enlarged. The intestines are inflamed and are full of mucus."

"The evacuations may show any or all of the color conditions commonly observed in cases of severe diarrhea, watery, mixed watery and solid, whitish, greenish, bluish green, brown, red, bloody. Particular colors or conditions may represent the degree to which different organs are affected, or indicate to an experienced eye the progress of the disease, but to the layman they have no special significance." (Robinson.)

Treatment.-If possible the catuse of the trouble should be ascertained and removed. This is by all means the first and 
most important step to take. It is uscless to spend valuable time in doctoring sick birds while the conditions which gave rise to the trouble are still present. In bacterial enteritis sick birds should be removed from the flock as soon as noticerl. Houses and runs should be cleaned up and disinfected. Drinking ressels and food troughs should be scalded daily. Potassimm permanganate should be used in the drinking water (cf. p. I6). Mix powdered charcoal with the mash. Feed less bran and more middlings in the mash. Do not feed too heavily.

After attending to the above hygienic measures the bircls should be given a good physic. A teaspoonful of Epsom salts to each fowl, dissolved in water and mixed in the mash, is the most convenient way of treating a large number of birds. For medical treatment Salmon recommends one of the following:

"Subnitrate of bismuth, 3 grains; powdered cinnamon or cloves. I grain; powdered willow charcoal, 3 grains. Give twice a day mixed with food or made into pills with flour and water.

"Subnitrate of bismuth, 3 grains; bicarbonate of soda, I grain; powdered cinchona bark, 2 grains; mix and give 3 times a day in a paste made with rice flour. When diarrhea is arrested, bismuth and soda are no longer neederl. Give as a tonic: Powdered fennel, anisc, coriander, and cinchona-each 30 grains; powdered gentian and ginger each I dram, powdered sulphate of iron, 15 grains. Mix and give in the feed so that each fowl will get 2 to I grains twice a day."

\section{Constipation.}

Constipation occurs in adult fowls far less often than diarrhea. It frequently passes unnoticed unless very severe. This trouble is much more common in young stock than in grown birds. In adult forls it often occurs in comection with indigestion, gastritis, or peritonitis. "A not infrequent canse is obstruction of the rent by accumtilations of excrement on the feathers about it This is especially apt to occur following looseness of the bowcls in fowls, which do not roost. Intestinal worms also may canse constipation by accumulating until their mass blocks the passage." (Robinson.)

Lack of exercise, or lack of green foorl are also occasional cansics of constipation. 
'lle slmntoms are painful and ineffective efforts to eracuate the bowels. In the worst cases the vent becomes completely plugereel with dry, hard feces. 'The birds ajpear dull, listless ancl without appetite.

Triatmint.-." Nelult fowls having constipation without obstruction of the intestines, that is merely diffenlt movements, should not require any treatment further than in correcting conditions and cliet. When the passage is obstructerl the treatment is: according to the location of the obstruction. If it is at the rent with hard accunnulation abont the rent as well as in the intestinc, the external accumulation must be removerl first. This $i=$ accomplished by soaking in warm water. which loosens the attachment of the mass to the skin, and separates it enough to allow clipping the feathers about the vent to which the mass alheres. If the obstruction has filler the lower part of the intestine, there must be more soaking with warm water or softening with olive or sweet oil. Oil is applied between the accumulated excrement and the skin by 11 sing a small syringe or an oil ean with very small nozzle. The process is a tedions one, and where the poultryman's time is valuable is umprofitable except in cases of valuable birls."

"When the obstruction cannot be reached in this way purgatives must be given. Those ustlally recommended for fowls, are castor oil, Epsom salts, and calonel." (Robinson.)

\section{INDIGESTION.}

lirids frequently suffer from disorders of the digestive system which are not easily classified under any of the liseases so far treated. Simple indigestion or dyspepsia most frequently results from overfecling and the feeding of ground grains and meat withont sufficient green food, are some of the canses 11sually given.

Symptoms.-The birds are dull and listless. They are inclined to sit on the roosts, and usually have but little appetite. Occasionally birds suffering from indigestion have an abuormal appetite and will eat ravenously quantities of foods which furnish lnut little nourishment,. g., grit. Indigestion is often accompanied loy either constipation or diarrhea. In the latter case the symptoms are similar to those described under simple diarrhea $($ p. 37). 
Treatment.-In treating indigestion it is important to observe the general rules of hygiene (ci. Chapter II). 'The house should he clean and as free from dust as possible. Sunshine should be able to reach every comer of the pens. The water dishes should be kept thoronghly clean and the supply of water should be kept pure and fresh. Use potassimm permanganate in the drinking water as directed on p. 16 . Use well balanced rations and feed at regular hours. Put fine (chick size) charcoal into the mash in consiclerable quantity. Enough shonld be used to make the mash decidedly black. This is a very inportant measure for the treatment of indigestion. Give the birds plenty of exercise. A small amount of a good stock tonic may help to bring the birds back into proper vigor. The following formula (irom Me. Agr. Eixpt. Stat. Ann. Rpt. I 896 ) has frequently been used with good success.

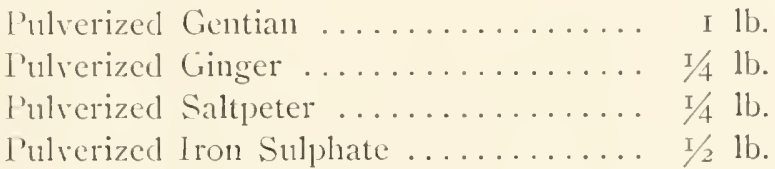

'These substances can be procured from any drug store and mixed by the poultryman. Use 2 to 3 tablespoonsful of the tonic to 10 quarts of dry mash.

Dr. ‥ W. Sanborn (Reliable Poultry Remedies) recommends the following treatment for indigestion: "If for I week at the beginning of the improved care you will add I teaspoonful of sulplate of magnesia to every quart of drinking water, and follow this for 2 weeks with $1 / 8$ of a grain of stryclunine to each quart of water. you will hasten the time when the bircle will be well." 


\section{CHAP'TER VI.}

\section{PoIsons.}

Poultry on free range about farms and especially on small city lots of ten obtain poisonous stubtances. Most of the poisons obtained by fowls are the so-called mineral poisons. The chief symptom of poisuning by these substances is actute inflammation of the digestive tract. The narcotic or vegetable poisons on the other hand cause severe congestion of the blood vessels in the spinal cord and brain.

Among the principal poisons likely to affect ponltry may be mentioner the following:

Common Salt, Nitrate of Soda, Concentrated Lycs.-Common salt is most frequently obtained in excessive amount from eating salt meat or fish. Ziim says that $15-30$ ( $1 / 2$ to $I$ oz.) grams of common salt will kill a healthy hen in from $S$ to I2 lours. Nitrate of sorla is used as a fertilizer and is eaten by hens along with worms, etc., which they scratch up. Lye is obtained only when carelessly left abont the grounds. The treatment for such poisons according to Salmon is to give "abumclant mucilaginous drinks such as infusion of flaxseed, together with stimulants, strong coffce and brandy being particularly usefull,"

Arscnic may be obtained either from rat poison or from various arsenical sprays used to kill insects. Copper is used in such spraying mixtures as Bordeaux. Where spraying has been done properly there should be no danger of the birds getting enough of the poison to injure them. Sometimes, however, the vessels containing the mixtures are emptied within range of the fowls or the substances are handled carelessly in other ways.

The symptoms of arsenic poisoning are given by Beeck (Die Fiedervichzucht igo 8, p. S28) as follows: "Secretion of large quantities of saliva, choking. hiccoughing, great anxiety and nerronsness, little or no appetite, thin, often bloody feces, slow and difficult breathing, unsteady walk, trembling and convulsions, expansion of the pupils. Death ordinarily occurs in a 
very short time." Treatment should be with sulphate of iron, calcined magnesia, or large quantities of milk. Salmon alsn recommends white of egg and flaxseed mucilage.

The special symptoms of copper poisoning are vomiting and diarrhea, the copper giving a bluc or green color to the vomited matter and the feces. Evidence of violent pain may follow with collapse, convulsions or paralysis. The circulation and respiration are weak. Usually fatal in a few hours. I arge quantities of milk, white of egg, mucilage, and sugar water are recommended.

L.cad and sinc poisoning occur chicfly from eating paint skins. The symptoms so far as they have been observed in poultry do not differ greatly from those seen in copper poisoning. The treatment recommended by Salmon is the same as for copper. With lead poisoning the sulphates of soda, potash or magnesia are recommended with the object of forming insoluble sulphate of lead.

Phosphorus may be obtained from rat poisons or from heads of matches. If large quantities of phosphorus are eaten by the bird severe inflammation of the stomach and intestine occurs and death results in from I to 2 hours. If only a small quantity is caten the symptoms, according to Beeck, are weakness, languror, ruffled feathers, lack of appetite.

Strychninc is nsually obtained by poultry from rat poisons. The distinctive symptoms here, according to Peeck, is the twisting of the spinal colmm and paralysis. The neck is twisted backwarl so that the head is often held over the rump. The treatment recommended by Beeck is to give "inhalations of chloroform or intermally i to 3 grains of chloral hydrate dissolved in 2 tablespoonsful of water. The amount to be given depends on the size of the bird.

Eirgot of $R y^{\prime}$ is one of the regetable poisons which sometimes catres serious troulble among poultry. This is especially true in European countries. In this country so little rye is raised and fed to poultry that there is little chance for poisoning. The canse of the poisoning is a fungus which attacks the rye plants. The symptons of ergot poisoning are trembling. intorication, great weakness and gangrene of the comb, beak and tongue. The treatment is to give strong stimulants such as "brandy, coffec. camphor or ruinine." 
Fowlis are oceasionally injured by cating the leares of proisonons plants. The sense of taste, howerer, protects the birds in most cases. Mr. H. B. Green (Illus. Poultry Record, Vol. I, p. $\left.68_{9}\right)$ says in this connection: "Woodlands and fied ls abound in prisonons plants, and yet it is seldom, except in the case of birls that have been starved of green food and have become ravenous for it. that forls ever stecumb to regetable poisons as thus obtaincel. Protection apparently lies in the fact that undesirable plants have repulsive flavors. Especially in suburban ponltry kecping. danger arises when flower borders are wecled, scedlings thimed out, and plant rubbish swept up, if the resulting collection is thonghtlessly giren to fowls in confined runs. Such birds are generally always ready for green fool in any form and in their eagerness to satiate the craving the barl is often taken in with the good."

TREATMENT FOR POISONS IN GENERAL.

'The above paragraphs have dealt with poisons rather more fully than is nsual in treatises on poultry discases. In the great majority of cases a poisoned birel is not discovered until too late for treatment. Exen if found in time it is nsually not worth the poultrymans time to treat individual birds. The symptoms of the different poisons have been given in some detail with the hope that they may enable the ponltryman to distinguish the kind of poisoning which they may encounter and may thus be able to remove the source of the trouble before other birds are affecterl. 


\section{CHAP'TER VII.}

\section{DISEASES OF TIIE LIVER.}

"The anmual losses of poultry the to liver trouble in various forms are nlumerous. 'l'hese diseases seem to occur chiefly among arlult fowls, and to be more prevalent in the latter part of the winter and through the spring. The reasons for their frequency then are easily found. The common forms of liver trouble result from improper feeding and lack of exercise. 'These causes operate most extensively during the winter, and they ustrally operate slowly, and the symptoms of liver troubles are generally obscure and not recognized until a post-mortem of fowls dying without special outward symptoms shows a diseased condition of the liver. Hence liver trouble may become gencral and reach advanced stages in a flock before their presence is suspected. Meantime, the conditions which cause them may be continued, the owner of a flock not infrequently supposing that the absence of sickness in it contradicts the teachings of those who advise methods designed to preserve health, while as a matter of fact many of his fowls are in a quite advanced stage of some liver complaint." (Robinson.)

A large number of diseases of the liver are described loy writers on this sulpject. In the great majority of these diseases there are no external symptoms by which one can be told from another. The most common diseases which affect the liver may. for the moment, be divided into two rough classes which it is highly important for the poultryman to distinguish. These again can only be distinguisherl in dearl birds, lut the nectrrence of cases of either kind in any number gives the penttryman a clue as to what the trouble may be and a clanee to correct it. In the first of these two classes a post-mortem examination shows the liver covered with nodules of a cheesy-like appearance when openerl. These nodules ocenr not only in the liver but also in the splecn, intestine and other organs and sometimes in these latter regions without affecting the liver at all. With such symptoms 
we maly lu farly certain that the trouble is tuberculosis and for a further discussion of this the reater is refered to Chapter vill.

In the second class of these discates the liver shows great enlargennent and this is often accompanied or followed by fatty degencration. This hypertrophy of the liver is what is gencrally spolicu of by poultrymen as "liver discase." "Liver disease" as popularly interpreted inclucles a number of different discases distinguished ly the pathologist. Of these the ones nus commonly treated in the diseases of poultry are Congestion of the Liver, Inflammation of the Liver, Atroplyy of the Liver, Iypertrophy or Enlargement of the Liver, Fatty Degencration of the Liver and Jaundice.

The diagnosis of these different diseases is based entirely on the post-mortem appearances. In no one of them are there any outward symptoms which distinguish it from the others. "Vale says it is impossible for the most scientific observer to cliagnose cither inflammation or congestion of the liver with positive certainty. The symptoms are much the same and outwardly are the general symptoms of (lisease." (Rol)inson.)

Further not only the symptoms but also the causes and the treatments of these sereral discases are essentially the same. The names of the diseases themselves indicate in a general way the post-mortem appearances.

For these reasons it seculs best to give a brief discussion of the general causes of "liver disease" and the usual treatment. 'This will be followed by a brief accomnt of each discase and its special symptoms and treatment, if any.

Callsi of Liz'cr Discasc.-Lack of exercise and overfeeding. especially with rich albuminous foods, are the nost common causes of discases of the liver. In addition to these Salmon mentions the obstruction of the circulation of the blood by disease of the heart and lungs. Sanborn says that congestion of the liver may be cansed by any disease of the crop, gizzard or bowcls that obstructs the circulation of the blood. Robinson says: "By far the larger proportion of the cases of liver trouble coming to my notice are accounted for by bad feeding conditions."

Diagnosis of Lizer Discase.-There are no special external symptoms. Sanlorn mentions as early symptoms: "Rough plumage. watery diarrhea, first brownish, then yellow; lack of appe- 
tite and indisposition to more. 'The comb may be purplish at first, becoming dark and then quite black." These, bowerer. are all merely srmptoms of disease in general that might apply to any one of a fozen or more ailments. The only certain method of recognizing the discase is by post-morten examination. Fivery poultyman should be familiar cnongh with the normal appearance of the more inuputant intermal organs of a fowl to recosnize abnomal appearances. In general, when post-mortem exanination shows the liver larger or smaller than normal or congested with blood or marluled or spotted, we may assume that the bird probably had some form of liver discase. Of contre, at discased condition of the liver is often associated whith other diseases. especially of the alimentary canal. Other organs shotld be cxamined in all cases to see if they are normal. Special care should be taken to distinguish tuberculosis from other discased conditions of the liver and intestines.

Treatment.- Since it is not possible to recognize discases of the liver by external symptoms, the treatment of inclividual birds is ont of the question. If, however, post-mortem examinations show that a number of the birds are lying with liver trouble it is necessary to take some remedial measures regarling the entire flock. In this connection Rolninson gives the following remarks and advice:

"Just as soon as it is suspected that there is liver trouble in the flock one or more indisposed birels slould be killed and cxaminerl. If examination confirms the suspicion prompt measures should be taken to counteract bad tendencies. These shonld lnok first to good diet. Nake the mash, if mash is 11sed, light and bulky; feed green and vegetable foods liberally; compel cxercise in scratching for food. Then get the fowls ont a little every clay, and if sanitary conditions in the house are at all objectionable correct thenn. When the ennelitions wo which a flock has been subjecterl are strch that a number of bad cases of liver tromble develop, it camnot be expected that corrective measures will arest development and restore to health in erery case. On the contrary, a fell cases may revelop in spite of remerlial measures, and the fowls exposed to the rliscatse are likely to give a much larger proportion of cases of sickness of various kinels afterwarls than fow that as a fleck hat always been healthy. 
'Thi- being the case, it is generally good policy to dispone of a flock that has been throngl such an experience as this as soon as it can be rone to advantage, and replace with always healthy stock."

With regard to the special discases already mentioned the one most commonly net with on intensive plants at least is

\section{Hypertrophy or Enlargement of the Lia'er.}

The cause of this trouble is chiefly concerned with food. In our climate it occurs most frequently towards the encl of the winter. The birds have been confined to their houses most or all of the winter months. Very often they are overcrowded. The rich winter ration is continued after the weather begins to get warm and less heating food is needed. This combined with too little excrcise and not enough green food favor indigestion and the accompanying sluggish action of gizzard and intestines. These are the immediate causes of trouble with the liver. It is said that feeding too much corn and barley is also responsible for much liver trouble.

Symptoms.-Mr. H. B. Green, M. R. C. S., gives the following symptoms of hypertrophy of the liver. He believes this to be only a stage in the fatty degeneration of this organ. (Illustrated Poultry Record I909, p. 69I.) "The first sign that a fowl is tending towards fatty disease of the liver is increase in weight. The comb wattles and face remain a bright red or take on a clull bluish tinge from congestion. 'This sign of slnggish circulation tells of full blood vessels, and explains how it is that apoplexy so frequently supervenes at this period. The excrement is an important symptom to note. It is generally at first semi-liquid. of a dark yellow color, and evacuations are frequent. Thirst is noticeable and a large quantity of water is lrunk, especially after feeding. The appetite remains good, although the bird is capricious in what it eats. A post-morten examination of a fowl in this phase of the disease will show a liver considerably enlarged, of a deep red color, engorged with blood, shining and greasy as though it had been soaked in oil, but fairly firm under the knife. The intestines are laden with masses of fat, so also are the mesentery-or as it is termed by butchers, 'the leaf.'the ovary and oviduct."

In the next stage "Diarrhoa increases, the excrement being 
perhaps bloodstaned or blackened by congealed clots; the face, comb and wattles become a darker hue or if jaundice supervenes they may be pale or tinged with yellow lite; more fat is laid rn internally and the liver will prove to be greatly enlarged. So large may this become by the deposit of fat globules between and in the substance of its cells that on one occasion I have removerl from an Orpington cock a liver that tumed the scale at a pound and a half. This stage is seldom passerl and death usually takes place from syncope, or an accilental rupture of the softened liver."

Treatment.-Green says further: "Part of the treatment consists of a plentiful allowance of green food. Nothing in this way is better than freshly gathered dandelion leaves when procurable, for the taraxacum they contain is a valuable liver stimulant. It is not generally known that the sliced roots of the plants can be steeped in boiling water to make an infusion equally effective when the leares are no longer obtainable. The roots should be gathered and stored in dry boxes. The infusion is conveniently mixed with the morning soft food and is always beneficial to birds in confinement as an occasional liver tonic."

\section{Fatty Degeneration.}

As noted in the above paragraphs. Green regards this disease as a later stage in the hypertrophy of the liver. Salmon, on the other hand, believes it to be a quite different discase. The latter author says: "On post-mortem examination the liver is found shrunken, hardened and marbled or spotted with areas of grayish or yellowish tissue. A microscopic cxamination shows the liver cells to contain droplets of fat and the liver tissue degenerated and largely replaced by yellow fat globules.

As the discase is not recognized during life, treatment is out of the question. If a number of cases occur in the same flock. give greater variety of food and a rum on the grass. In addition, bicarbonate of soda may be given in the drinking water to the amount of I or 2 grains a rlay for each bircl." 


\section{Arophy or II asting of the livitr.}

'This is very sinilar in many respects to the discase described hy Salmom as fatty degeneration and probably arises from the sance cause, $i$. $c$. lack of variety in the food, especially lack of green fond.

Symptoms.-Rolinson says: "'There are no special external slmptrms. An examination of the fowl after deatl shows the liver shrumken and somewhat gramular and sometimes of a yellowish cast."

Tratmont.-See Salmon's treatment of fatty degeneration above. The flock should be given frequent (weekly) doses of Ejsom salts.

\section{Comgestion and Inflammation of the Liver.}

'l'hese are probably different stages of the same disease. 'The poultrynan will find difficulty in distinguishing between this risease and that known as hypertrophy of the liver (cf. p. 50). The chici post-mortem difference is that in the latter disease the liver is more solid, not so easily torn or ruptured.

I) iagnosis.-There are no external symptoms other than those of dullness and the general symptoms of disease. Salmon says: "It is difficult to make a diagnosis during the life of the bird. Post-mortem examination reveals a greatly enlarged liver engorged with blood, tender and easily torn or crushed."

Tratment.-Treatment of these diseases in individual birds is rery rarely sucessful. The general treatment of the flock as recommended on p. 49 should be attended to. The chief medicinal treatment should probably be frequent doses of Epsom salts. Various authors recommend different medicinal treatments. For these see Robinson (pp. 7r to 74 ).

\section{Jaundice.}

Jamulice or libliary repletion is said by Megnin (Merlicine des ()iseanx) to be due to long continued but moderate congestion of the liver. This leads to increased activity of this organ and is followerl ly the accumulation of a large quantity of bile in the gall bladder and ducts of the bird. This bile is alosorbed by the bloxd ressels and causes poisoning which may lead to the leath of the bird.

Diagnosis.-There are no specific external symptoms other 
than that the wattles and comb nay be yellowish. 'This also occurs in other liver diseases. I'ust-mortem examination shows the gall bladker greatly distended with bile.

Treatmint.-Cive greater variety of fool, especially more gareen food. Give Ejsom salts frequently. Megnin recommends ${ }^{1} / 2$ to I srain of aloes.

'This completes the list of the liver diseases most commonly treated as such by poultry reterinarians. There are a number of other discases which especially affect the liver or are caused by deranged function of this organ. These may most conveniently be mentioned at this place.

\section{Blackhcad (Infections Intero-Hcpatitis).}

Blackhead is essentially a disease of turkeys. It is not the intention of this work to treat discases of poultry other than fowls. Conseqnently little will be said abont this disease except as it applies to fowls. If further information is desired the reader is referred to the Rhode Island Experiment Station. Kingston. R. I., for bulletins relating to this disease. That station has been and still is stndying this disease in a most thorongl way.

Blackhead is a contagious disease affecting the liver and intcitines. especially the blind ponches or ceca of the latter. The disease is rery quickly fatal among turkeys. The turkey is apparently more suseeptible than any other birel to this disease. In certain portions of this comntry where once turkey raising was a promising industry it has been practically annihilated. The disease is not usually as fatal to adult chickens but may cause very serious loses at times. It is now believerl by several prominent investigators of this disease that white diarrhea, so destructive to young chicks, is cansed by the same organism as blacklearl. For further discussion of this see Chapter XIX.

The canse of blacklearl disease accorling to Dr. Theobald Smith (Bur. An. Incl. Bu1. No. S) is a minnte parasitic protozoan known as Amoiba meleagridis. More recently Drs. Cole and I Iadley of the Rhode Tsland Experiment Station have claimed that the cancative organism leelongs to another gronp of protozoa known as Coccidia. Dr. Smitl. howerer, still maintains that the former organism is concened in the disease. The point to this cliscussion lies in the fact that the Coccidium has 
a rery different life history from the smocba, consequently it probably has a different method of dispersal and different means mutst be need in combatting it.

Diaynosis.-There are 110 special external symptoms of this disease nntil in an arlvanced stage. 'The victim then begins to mope, loses its appetite and is inclined to sit apart with drooped wings. The head and comb take on a dark color from which the di-case takes its name "blackhead." One of the most conspiculons symptoms is the diarrhea. Post-mortem examination show: the liver enlarged and disfigured with whitish or yellowish spents. The ceca are inflamed and often clogged with pus and fecal matter.

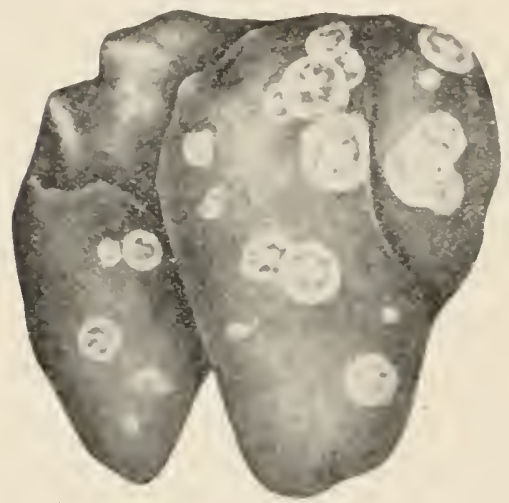

Fig. I. Showing condition of liver in "blackhead." (Modified after Noore).

Treatment.-Medical treatment of turkeys affecter with blacklicad is of little avail, at least in the present state of our knowledge. Cole and Hadley (Rhode Island Expt. Stat. Bul. I 4 I) recommend the following: ( I) Isolate the sick bird from the flock and place it in a dry, well lighted location free from cold and draughts. (2) Feed sparingly on soft, light, easily assimilable food, with little grain, especially corn." The chief preventative measures are to keep the lirels on fresh gromul; to isolate any birds showing the least sign of disease, to destroy all dead birds and to protect the turkeys from contamination carried either by new stock or by other poultry or by wild birds as sparrows, crows, etc. Dr. Morse (1). \. I. Circ. I 28 ) recommends for turkeys under 3 months old $1 / 2$ grain copperas in the morning and a $2 \mathrm{~T} / 2$ grain pill of salicylate of sorla in the evening. Give Epsom salts every 3 or + (lays and keep the gronuds and floors well sprinkled with lime.

With fowls the discase is not so virulent but it is still well to protect the flock from introduction of this disease. In this comnection Dr. Cole (American Poultry World, I9Io) says: "It is 110 uncommon thing for adult chickens and other poultry 
to die with all the pathological appearances of blackhear, which diagnosis has been confirmed with the microscope. Furthermore, infection there with this organism appears to be one of the principal causes of death of broorler chicks, which exhibit the symptoms of one form of the poultryman's greatest scourge, white diarrliea.' It has often been saicl of late: If you want to raise turkeys keep them away from chickens; it might be sidil with even greater emphasis: If you want to raise chickens. keep turkey's away from them."

Dr. G. B. Morse of the U. S. Department of Agriculture sives (Reliahle Poultry Journ., Sept.. 1910) a number of other discases which affect the liver. Some of these which are not treated elsewhere in this circtular will be mentioned in the following paragraphs.

\section{Cercomonicisis.}

This is irequently called "spotted liver." It, like many other liver discases, is associated with intestinal trouble. especially severe diarrhea. that attacks poultry during the summer months. The disease is caused by a flagellate micro-organism known as . Wonocercomonas gallinarm. The post-mortem appearance of the liver in this disease show's usually slightly depressed yellowish necrotic areas or spots. This fact usually distinguished this discase from tuberculosis where there are prominent rounded cluesy nodules. In pigeons, however, this cercomonad is said to cauce rounderl prominent nodules about the size of a pea.

T'his same organism (.Monoccromonas gullinarum) is also saicl to be responsible for other discases. The most important of these is one form of roup. Canker in squabs and intestinal riarrhea in poultry are other diseases attributed to this parasite.

'This dicease can he held in cleck, it is said. by keeping the poultry plant well cleaned and disinfected and by giving the hires an occasional purgative, $c$. g.. Epsom salts.

In asfergillosis, the liver often presents the appearance of being "studled all over with minute, whitish or yellowish spots." This disease is discussed in Chapter XIX.

\section{Sarcomatosis and Carcinomatosis.}

In some cases the liver is affected with tumors or cancers. These are usually found in connection with sinilar derelopments on the ovaries. 
Gout.

In casen of visceral sout the liver and arljoining organs are covered with a line chalky serliment. This substance consists of crystals of urate of soda. See Chapter $\mathrm{Xl}$. for detailed description. 


\section{CHAP'TER V'HI.}

THIBRCLIRSIS.

Tuberculosis in fowls has long been a serious pest in Enrope. Zïrn in his "Krankheiten des Hansgeflïgels," published in I8S2. derotes several pages to the description of this disease as it ocenred in Cermany. Its aplearance in this conntry, howerer. scems to have been much more recent.

Saltuon, whose look was publisherl about 1888 , says that the diseace "is by no means rare in the Lnited States if the statements of onr professional men are to be accepted." Thowever. at that time very little had been done in the way of bacteriological diagnosis and no douth many of the early reports were unroliable.

The disease was first reported on the basis of bacteriological cxamination in 1900 by Pernot (Oregon Agr. Fixpt. Stat. Pull. 64). In 1903 . Nowe and Warel reported investigations on avian tuberculosis in California (l'roc. An. Vet. Med. Assoc. 1903). 'They foumd "a number of flocks in which the mortality from the disease was yery high." Fowl tuberculosis was reporterl from western and central Canada in $190+$ by Dr. C. II. Higgins (Dept. of Agr. Canada, 1905). In 1906 it was reported from New York and in 1907 from sonthern Michigan. The discase has been reported in many other places within the last few rears. It thus seems certain that the disease is widesprearl throughout the United States and Canarla and in the future must be reckoned with by Anerican puntrymen.

Tulerenlosis may exist extensively anong fowls. especially in large flocks, and yet not kill enough bires to attract attention to it. Reports show that farmers often lose 1 or 2 bircls a year from what appears to be tuberculosis. In many places the loss secms to be gradually increasing. The existence of the disease in the flock fails to attract the attention of the owner hecause the loseces are se evenly distributed throughout the year. Noore and Whard report a flock of 1,400 birels from which 250 had died dering the first year. Another man ling zoo birels ont 
of a flock of 1 foo. Microscopic exannination proved that these were lying of tuberculosis.

'luberculosis is confined chiefly to adult or nearly adult fowls. Only very rately, if erer, is it fomml in growing chicks. Further it is much nuore common in fowls than in other kinds of ponltry. Pwe cases in wild geese were reported at the Ontario Agricultural College. Avian tuberculosis is said to be found in turkeys, pheasants, and especially in pigeons. Cage bircls are particularly susceptible to this disease.

litiology-CTuberculosis is caused by a minute germ, the Bacillus tuberculosis of birds. These bacteria gain entrance to certain portions of the body and there multiply in vast numbers, cansing the formation of small nodules or tubercles. The disease is highly contagions and is spread through the flock by the contact of healthy birds with the cliseased ones, or with their discliarges.

The relation of avian tuberculosis to that of man and other animals has attracted a great deal of attention. It is a subject of rery great importance to the poultryman, not only on account of his flock but also on account of its relation to the health of himscif and his fanily. In this connection, writing some years ago Salmon says: "Many outbreaks (of fowl tuberculosis) have been attributed to infection from eating the sputum of persons affected with consumption. The possibility of such infection is admitted by some authorities and denied by others. It is certain that poultry and pigeons are not easily infected experimentally with the tuberculosis of people, cattle and other animals which are classed together as mammals." On the other land, "The bird or avian tuberculosis spreads rapidly from bird to bird and is easily transmitted experimentally to birds but it has little effect upon most mammals which are very susceptible to human tuberculosis. There is, consequently, a marked difference between avian and mammalian tuberculosis. The discase in the two cases cloes not appear to be absolutely distinct. but should rather be regarded as two varictics of the same malady."

In the last few years a great deal has been found out about tuberculosis in both bircls and manmmals. The results have been summarized and extended by Drs. Koch and Rabinowitsch in an extensive paper clealing with avian tuberculosis anel its 


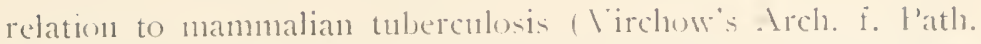
Anat. 11. I'hys... cte. Bicl. 190, pp. 2f(1-541, 1907). Their restlltmay be brietly stated as follows: Attempts to infect fow with mammalian tuberculosis, like the earlier negative results of other anthors, have been fruitles. Howerer, fuwls are very easily infected with avian tuberculosis ly feeding them parts of discaserl birds. On the other hand. methods of infecting forls other than feeding are not always successful even with arian tubereulosis. Other birds, especially cage hirds, are very rearlily infected in various ways. Parrots, in particular, are susceptible not only to avian tuberculosis but also to mammalian and human tuberculosis. Also canary birds, sparrows, and rarious bircls of prey were proven to be susceptible to both arian and mammalian tuberculosis. In these respects such birds differ materially from the domestic fowls.

On the other hand their later researches have made it apparent that a lare number of mammals are susceptible to avian tuberculosis. These include not only the small laboratory animals as rabbits, mice and guinea pigs. but also cattle, hogs. horees, goats, and donkeys. Also avian tubercle bacilli have been found in caces of human tuberculosis. On the basis of such experiments and observations it appears that arian and manmalian tuberculosis are not caused by different species of bacteria but by different varieties of the same species. These varieties have fleveloper hecause the bacilli have grown for a long period of time under different conditions. 'They are not so different, however, but that they may grow in the environment best suited to the other one.

It thus appears that ahile fowls are not ary likely to contract tubcrulosis from domestic animals or from man. y't foals that hai's the discases are a serions menace to the other animals on the farm as a'cll as to the pouliryman and his family. ( $C f$. further on this point p. $\sigma_{+}$below).

Diugnosis. 'luberculosis in mankind is so serious a disease chiefly because it is so difficult to recognize it in its earliest stages. The same is true with the discase in fowls. There are positively no external symptoms by which the disease can le recognized in fowls before the adranced stages. Morse (R. P. I. Sept. 1910) says on this point: "There is a combination of symptrms that might serve to arouse your inspicions: iteadily. 


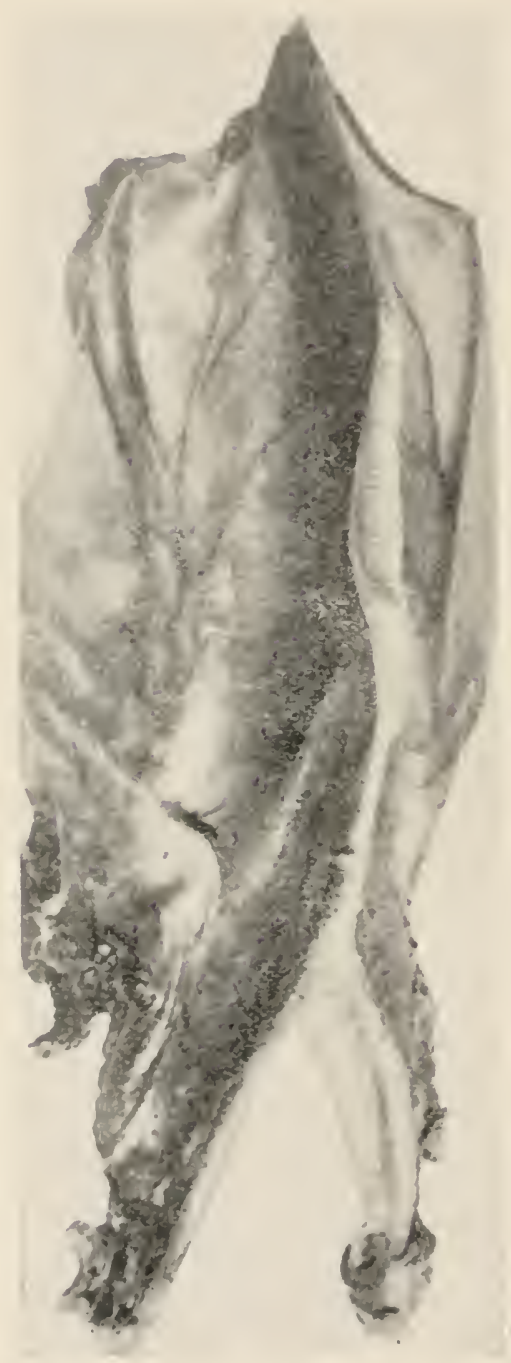

Fig. 2. Breast hone oi a fowl showing excessive cmaciation in tulerculosis. (After Ward). allancins enaciation: anemia, sluown by pallor of comls wattles and the skin about the licarl: general weakness : lanseness, ruflings of the feathers anci in matus: cases diarthea. 11 hen combined with the foresoing you notice a lorigint eye and a ravcnous appotite you may have vory strong suspicions."

Fnnaciation is one of the best symptoms anci in the last stages of the ilisease becomes very marked. Pernot cites the case of a Plymonth Rock hen weighing 4 pounds that was reduced to 22 ounces. 'ine emaciation is very marked mine thuscles covering the breast bone. Fig. 2 shows the breast bone of a tuberculous hen from which the skin only las bean remored.

Lameness is another simptom often shown in the later stages of tine disease. This is cansed iy tuberculosis of the joints as inas been proven in many cases. Such cases aro often ca!led "rheumatism" by pouitrymen. Tuberculosis may also form tumors or mlecrs or various outgrouths on the liearl and limbs of birds. Such forms of the
discase are compatatively rare in poultry, however. Parrots are particularly affected with those external tubercles.

None of these srmptoms, howerer, is more than an indication 
of the posibible presence of the diecase. Morse salys: "It the post-mortem examination gen maly haw your suspicions strengthened by finding liver. splecen, intestince and membranc uniting the intestinal folds (mesenteries) studeler with yellowish white cheesy noslules of various sizes." Ontside of the bacteriolenical test these post-murtem findings are the best proof of the disease we have. The liver is atfected in nearly every case of fowl tuberculosis. However, as has been pointed out many times in tinese pages. a spotted condition of the liver is no sure sign of tuberculosis. Mlost of the other liver cliseases of fowls camse a simple blotehing of the tissue in which the center of each spot is usually depressed or at least only slighty raised. (Ct. Fig. I, p). 54). In tuberemlosis the liver is covered

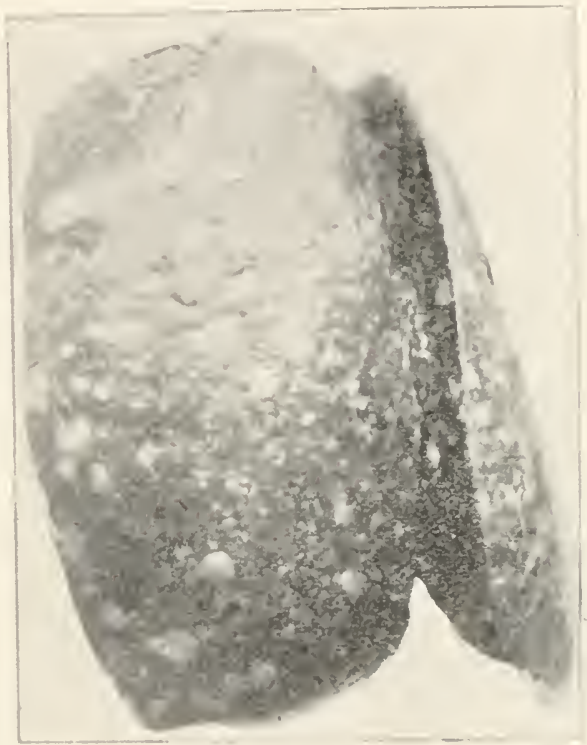

Fig. 3. Liver of fowl alfected with tuberculosic (.Ifter Ward). with numerous raised nodules varying greatly in number and size as shown in fig. 3. I section of the liver shows these morlules or tubercles distributed throughout the tissue.

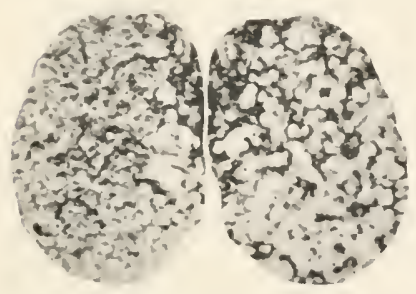

Fig. f. Spleen from tuberculous fowl cut through the midlle. (. Ifter Krich and Rabinowitsch).

Still mone eonclusive cridence is formel if the spleen is onvered with these same kind of notules. The splecu in health is a small roumeleel

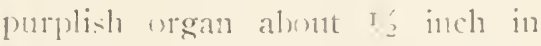
dianueter. It lies pust aloove the liver in the regiom wi the gall bladder. In eases of tubereulosis it is very fresuently greatly enlareser and is studeled througlent with the yellowi-h-white tubercles as shown iil lig. $t$. 
Still another very important piece of post-morten evielence is formel if the interines and the mesenteries are rlotterl with there rommeled noxlules as shown in fig. 5 .

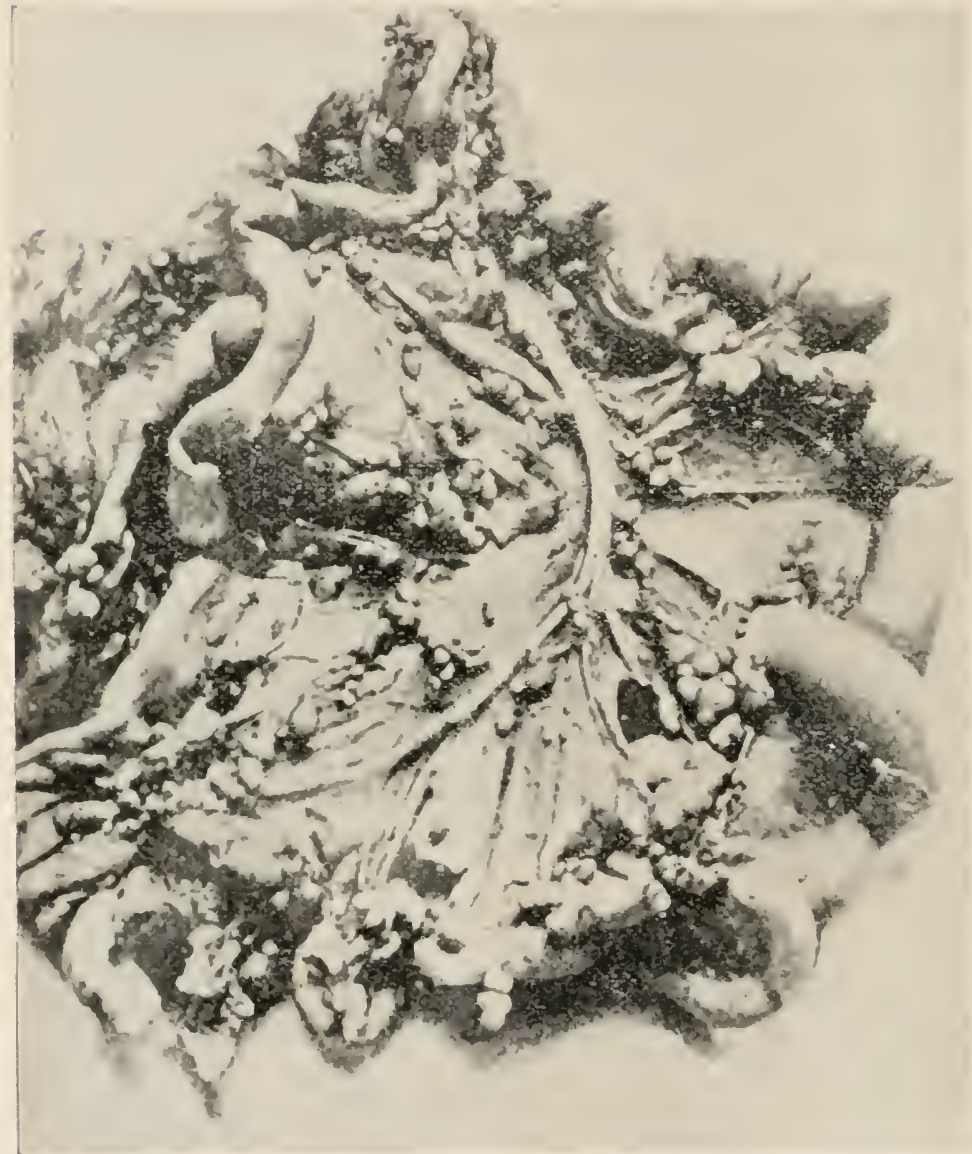

Fig. 5. Intestine and mesenteries of a fowl affected with tuberculosis. (After Ward).

The lungs are iory rarcly affected and then usually by the infection spreading from the liver on to the adjoining lung tissue. All this agrees with the fact previously stated that fowls are most easily infected through the digestive tract. Alteration wif the bones. joints or other organs occur much more rarely and 11sually only in the most adranced stages of the disease. 
If the post-mortem findings agree in essentials with those given in the preceding paragraphs we may he practically cortain that we are dealing with tubereulosis. It should not be forgotten. howerer, that the pathologist would not be willing to prononnce the disease tuberenlosis nuti] he had taken a small particle of the cheesy material and after staining this in a particular way had demonstrated by microscopical examination that the twbercle bacilli were present.

Moore and Mard have carried on some experiments in the use of tuberculin in detecting this disease. Ward (loc cit.) gives the results of trials on 2 t hens affected with tuberculosis. In very few cases did the tests give positive results and these were so slight and irregular as to be useless as a method of diagnosis. Apparently there is little hope of success in this direction with fowl tuberculosis.

Methods of Contagion. The spread of tuberculosis from fowl to fowl takes place only when the living bacteria are transferred from the diseased to the healthy birds. From the fact that tuberculons lesions are most commonly found in the internal organs of the digestive system we may conclucle that the bacteria 11s11ally enter the body along with the food. Examination of the tubercles situated along the intestine shows that in many cases these communicate directly with the interior of the digestive tract. These are constantly emptying cnormons numbers of bacteria which are carried to the ontside by the feces of the bird. Without doubt the droppings of tuberculous fowls are the most important factor in the spread of this disease. This is especially true when in addition the bircls are fed upon gromud which is partly covered with these droppings. liesides. the infections material may very easily be carried by the feet and thiss mixed with the food.

Ward states that there is no evidence to indicate that tuberculosis is spread through the egg. He cites in support of this the fact that badly diseased birds do not lay and second the absence of tuberculosis anong young stock. Koch and Ralinowitsch. however, on the basis of later and more thorough work nuake the following statement (p. 431): "The possibility of the congenital origin of tuberculosis of fowls through the infection of the fertilized egg with bird tuberculosis is slown by onl results. It is also demonstrated by our inoculation experimenti on 
egres." Finther they have given experimental proof of the transice of the hacteria of mammalian tulereulosis from the inculatid ay to the chick. As noterl before it was very difficult (1) de this by feeding the lens food infected with mammalian tuberculesis.

In this comnection it is of interest to mentions a case of the apparent transfer of fowl tuberenlosis to man. In the lleclical liecord (Vol. 31. Is85) there is recorded a case of human tulereculosis in liance which apparently came from eating tuberculous fowls which "were cookecl very little before being eaten." T'he case occurred "in a little hamlet of 10 cottages imlated in the mirlst of a large forest." No other source of infection enul: be liscovered.

Treathint. Fowl tuberculosis when it reaches the stage at which it can be diagnusel cannot be cured mncler our present linowledge. Treatment of individual cases slonld not be attemptecl. After it has been ascertained by post-mortem (and if possible bacteriological) examination that the disease exists in the flock all suspected birds should be remored at once. If the disease is to be controlled it must be by kecping the healthy and the affected birds apart. 'The most serious thing about tuberculosis is that there may be many birch in the flock that are in early stages of the lisease but do not betray their condition. Long before these birds show recognizable symptoms they are throwing out millions of bacteria which become a menace to the remaincler of the flock.

If only one or two cases of tuberculosis are fomel it may be sufficient to simply disinfect the houses, yards, feeding troughs and drinking ressels. This should be done with some good disinfectant. (Sce Chap. II). Morse recomments also the liberal application of lime referring to the fact that "lime workers seldom suffer with tubereulosis." 'The runs shomll be cultivated and the houses should be open to the stum shine and fresh air at all times.

If. howerer. the number of birch clying of tuberculosis in the flock is increasing eren thongh the increase is very gratual. more strenuous meatsures munt be taken. Luder these eonditions Dr. Morse says: "Kill everything in sight, lisinfect. allow the ponltry plant to lic fallow for several months, disinfect again and buy fresh stock that is known to be healthỵ." 'This no 
doubt is the surest way to get rid of the disease and wherever possible it slould be done. However, where the disease is found in large flocks of birds such measures would bankrupt the covner. Or a man may have a very fine strain of birds which he has spent many years in perfecting and which it would be impossible to replace. In such cases Morse proposes "Banging" out the tuberculosis according to the methods of new-her(l-building in dairy cattle as proposed by Prof. Bang of Copenhagen. Morse's directions for "Banging" ont tuberculosis are as follows: "Secure new or thoroughly disinfected grouncl, keeping it absolutely free from contact with the ground unsed by the infected flock. Erect new houses on this ground. Collect the eggs from the infected birds and wash them in 95 per cent alcohol or in a 4 per cent solution of some good coal tat disinfectant. Incubate these disinfected eggs in new incubators. When hatched, remove chicks to new brooder houses on the new gronud. These growing chicks should be cared for by new men, that is to say, either different men from those that care for the old flock or if you are compelled to use the same men they should disinfect their hands and shoes and put on fresh overalls before handling the new stock. Have different feed bins and different pails for distributing it. As soon as you have built $11 \mathrm{p}$ a clean flock destroy the old and disinfect the ground occupied by them by the method ontlined above."

This method is, no doubt, excellent in theory and if carried out with complete and never-failing attention to details might work. It is doubtful, however, whether in actual practice a poultryman would ever be able to carry it through successfully or profitably. 


\section{CHAP'TER IA.}

\section{CHOI.ER.1.}

Fonl cholera is a virulent, usually fatal and highly infectious discase. It is entirely distinct from the ordinary forms of enteritis with which it is often confused by poultrymen. Fowl typhoid and infections leukaemia are also often mistaken for cholera. Genume fowl cholera is rather rare in this comtry but is much more common in Europe. This disease was first reported in this conntry about isfo by Salmon (Rept. U. S. Commo of Agric.). Owing to the lack of proper bacteriological methods at that time Salmon was not able with certainty to identify this disease with the European cholera. From certain experimental work he concluded that some of the symptoms: exhibited by the disease in this country were different from those lescribed by European writers. Abont risgt Moore ( $\mathrm{C}$. S. Bur. An. Incl., Bul. \&) obtained material from several ontbreaks of supposed cholera but found this disease to differ in several important respects from the European trouble. Nore recently Curtice (R. I. Expt. Stat. Bul. 8j) has described a disease similar to that of Moore's muler the name of fowl typhoicl. What appears to be the genuine European fowl cholera has been reported sereral times within the last few years.

Fowl cholera attacks all varieties of poultry; also caged bircts and many species of wild birds. "The infection generally occurs by taking food or drink contaminated with the excrement of sick birds. It is also possible for birds to be infected through wounds of the skin or by inhalation of the germs in the form of clust snspended in the air. They often take the germs into their bodies by consuming particles of flesh or blood from the carcasses of affected birds that have died or have been killerl."

"The disease is generally introdnced upon a farm or in a locality, with new birds, purchased for improving the flocks or 
with eggs for hatehing. When it exists in a district it may be diseminated by wild animals or wild birkls." (Salmon).

Diagnosis: Salmon gives the following as external symptoms:

"The earliest indication of the disease is a yellow coloration of the urates, or that part of the excrement which is exereted by the kidneys. This in health is a pure white, though it is frequently tinted with yellow as a result of other disorders than cholera. While therefore this yellowish coloration of the urates is not an absolutely certain proof of cholera, it is a valnable inclication when the disease lus appeared in a flock and an effort is being made to check its conrse by isolating bircls as scon as affected. In a few cases the first symptom is diarrhea in which the excrement is passed in large quantities. and consists almost entirely of white urates mixed with colorless mucus. Generally the diarrhea is a prominent symptom. The excrement is voided frequently. and consists largely of urates stspended in a thin, transparent. sometimes frothy mucus. The urates have a deep yellow color, which in the later stages of the discase may change to greenish or even a deep green."

"V ery soon after these first symptoms appear the bird separates itself from the flock. it no longer stands erect, the feathers are roughened or stand on end, the wings (lroop, the head is drawn down towards the body and the general ontline of the bird becomes spherical or ball shaperl. At this periorl there i. great weakness, the affected bird becomes drowsy and may sink into a deep sleep which lasts during the last day or two of its life and from which it is almost imposible to aronse it. The crop is nearly always distended with food and apparently paralyzed. There is in most cases intense thirst. If the bircls are aroused and cansed to walk there is at first an abundant discharge of excrement followeel at short intervals by scanty evacuations."

In regarel to the yellow or green excreta Hadley* says:

"'This is a very characteristic symptem. The excrement of normal fowls is not yellow: and when it is green it is a dark green, approaching black. In cholera both fellow and green are bright; the green is often an emerald green. These different colors may occur either alone or separately and both are

\footnotetext{
*Bulletin r 44 R. I. Agr. Expt. Stat. (In press.) The manuscript of this bulletin was very kindly loaned by Dr. Hadley.
} 
nswally accompanied by diarrhea and thick mucus. In case it is known that cholera is in the neighborhood, it is well for a poultryman to examine, from day to day, the cluaracter of the droppings on the dropping board."

"The course of the discase may be rapid or slow in its progress through the flock. It may take all within a few days, or the fowls may drop off by twos and threes through a period of several weeks. After the first symptoms appear the development in individual cases is usually rapid. Forty cases investigated by Salmon averaged 3 days, but many birds die within a few hours after the diarrhea sets in. The time required to develop the disease after exposure or inoculation is given by Salmon as + to 20 days." (Robinson).

Examination of the dead birds shows inflammation of the digestive organs, kidneys and mesenteries in nearly all cases. According to Ward (Calif. Expt. Stat. Bul. I 56) "punctiform hemorrhages are found upon the heart with almost absolute miniformity. The liver is very frequently marked with punctiform whitish areas." Sections show that the areas of necrotic tissue are present throughout the liver tissue. The blood vessels of the liver are congested. According to WVard the next most striking lesions are found in the reddened and bleeding mucosa of the first and second folds of the small intestine (next to the gizzar(l). These reddened areas can even be seen from the outside of the intestine. The intestinal contents are of either a cream colored pasty mass or may be brownish or even green in color. "Lesions are very rarely observed in other portions of the intestine. The ureters are noticeable in practically all cases by reason of the yellow-colored urates that they contain. The nasal cavity, pharynx and oral cavity frequently contain a viscous mucous fluid, probably regurgitated from the crop."

Etiology. Fowl cholera is caused by a bacterium known as Bacterium bipolaris septicus. It is closely related to the bacillus of rabbit septicaemia and the bacillus of swine plague. " Under the microscope the bacterium presents either a circular or oval outlinc. It is about I 50-thousandth of an inch broad and 2 or 3 times as long. It grows best at from $85^{\circ}$ to $105^{\circ} \mathrm{F}$. It has no power of movement, does not form spores, and is easily destroyed by drying, by the ordinary disinfectants and by a temperature of $132^{\circ} \mathrm{F}$. for 15 minutes." (Salmon). 
Fowl cholera cannot be recognized with certainty except by a bacteriological examination. Practically, however, this makes but little difference to the ponltryman. The methods of combatting cholera are not radically different from those used against similar infections diseases. The occurrence of a number of sudden deaths in a flock indicate the presence of an infectious disease and call for the inauguration of sanitary and remedial measures at once. At the same time a letter describing the symptoms should be sent to the Division of Pathology, Bureau of Animal Industry, Washington, D. C. In this way the name of the particular disease can be determined and adrice as to any specific treatment will be received.

Treatment. "The best authorities on the subject regard genuine cholera as practically incurable. It is said that none of the alleged remedies have proved effective in cases known to be true cholera, and the presumption is that the persons supposing they had cured cholera with them were treating some other disease. While treatment of affected individuals is regarded as futile, the spread of the disease may be linited and the discase stamped out by disinfection to destroy the germs on the prenises, and by proper measures to prevent their further distribution." (Robinson).

Dr. P. T. Woods, who several years ago while manager of a poultry ranch in New Jersey, had considerable experience with cholera gives the following method of dealing with the disease. (Reliable Poultry Remedies).

"As snon as the disease is discovered, establish a pest house remote from the other poultry buildings, a place that can be easily and thoroughly disinfected. Isolate all suspected cases in the pest house as soon as you can find them. Give these birds a few drops of creolin in their drinking water (just enough to turn it faintly milky), or give them drinking water in which has been dissolved one one-tenth of a grain tablet of corrosive sublimate to the quart of water. All birds which show marked symptoms of the disease had better be killed and cremated at once. This is safest and best. Kill them by strangling or by a sharp blow with a blunt club, breaking the neck. Do not draw blood, as the blood is infections, and you do not want to spill it. If they bleed, scrape up all the blood and burn with the body, and disinfect the place where it fell. Rake 
11p) and burn all litter used in houses or runs occupied by infected birds. Spray the runs and all parts of the buildings with a strong solution of creolin, or a 1 per cent solution of sulphuric acicl in water. Do not use any litter until you are sure that the disease is eradicater. Thoroughly disinfect everything that conld possibly be contaminated by the infected fowls, ancl repeat this as often as you find a new case. The rums or yarls should be thoroughly disinfected and shoutd be ploughed ip often."

In connection with his work on an ontbreak of fowl cholera in California, Ward points out the following important conclusion: "Cholera and other infections diseases may exist in a fowl in a sort of inactive chronic condition and there is no doubt concerning the agency of such a case in spreading the disease. Thus, fowls not suspected of being diseased may have the discase smouldering among them. The fact that occasionally a single fowl dies of cholera means that a severe loss may occur at any time."

The practical recommenuation for an outbreak of fowl cholera then is to kill and destroy all sick birds. confine all well birds to small rums. Disinfect these runs and the houses daily. After the outbreak is over and the birds have ceased dying it is best to market all flocks in which the cholera appeared. This latter precaution will often prevent a second outbreak some months later.

Methods of prevention are always the most satisfactory. The careful poultryman will guard his flock against all infections diseases by methods of quarantine, disinfection and general cleanliness. At the same time the birds should be fed to keep them in the best of health. On these points read Chapter II.

Through the kindness of Dr. Philip B. Hadley the writers have had the opportunity to read the manuscript of Bulletin Itt of the Rlode Island Experiment station dealing with fowl cholera. On the basis of his experimental work Dr. Harley recommends subcutaneons injections of 5 per cent carbolic acid as a treatment for individual bircls. In the summary of this bulletin Dr. Hadley says: "At the Rhode Island Station attempts have been made to prevent the development in fowls of chulera artificially produced by inoculation with the fow cholera organism. The protective inoculations have involved 
subentancous inoculations with a 5 per cent solution of carbolic acid in amounts of from 2 to + c. c. claily."

"The results thus far secured slow that the inoculations as given protected artificially infected birds. and did no harm to birds that were in normal health. 'They therefore suggest that subcutancons inoculations with carbolic acil have a protective and perhaps a therapeutic value in fowl cholera." 


\section{CHAPTER X.}

\section{Diseases of the Amdominal Cavity.}

\section{Peritonitis.}

The thin serous membrane which lines the abdominal cavity and covers the internal organs is called the peritoneum. Inflammation of this membranc may occur in connection with the inflammation of certain internal organs such as the intestines, liver, kilneys, etc. In these cases the inflammation extends from the diseased organs on to the wall of the body cavity. Teritonitis may also be caused by the entrance of foreign bodies into the abdominal cavity. It may further be caused by severe bruises or injuries of the abdominal wall.

Foreign bodies enter the abdominal cavity chiefly through perforation of the intestine. This may occur through severe inflammation, by sharp-pointed objects pushing through the intestinal wall or by parasitic round worms or other parasites puncturing the wall. In many cases mature eggs separate from the ovary but fail to enter the oviduct. Or, owing to rupture of the oviduct or a reversal of its peristalsis, the egg substance may enter the abelominal cavity. Usually these eggs are absorbed or walled off without very serious annoyance to the birl. In other cases they may cause severe peritonitis. Finaly forcign bodies may enter the abdomen through such operations as caponizing.

Diagnosis.-The sick birds appear restless and lose their appetite. There is a high fever. The abdomen is swollen. hot and tender. Pressure on the abdomen produces evidence of sharp pain. Usually, but not always, a severe thirst accompanies peritonitis. As the disease progresses the bird becomes weaker, is mable to stand and the legs are drawn up cloce to the body often with convulsive morements.

Post-mortem examination shows the peritoneal membrane to be deep red in color (provided the bird has just ciied or has been freshly killed without bleeding). This membrane is ustl- 
ally covered with a thick opaque yellowish cxulate. This gives it the appearance of being much thicker than ustual. In some cases small lumps of whitish matter (pus) are found. The abdomen may contain more or less liquid which is usually yellowish and turbicl and may have an offensive odor. If a miscarried egg is the cause of the trouble portions of this will usually be found.

Treatment and Prognosis.-Only very scldom is treatment for peritonitis suceessful. The disease is not usually recognized until in an advanced age. Zürn recommends wrapping parts of the bird in wet cloths and to give internally tincture of aconite. 2 drops (at the most) with a teaspoonful of water 2 or 3 times a day. Sauborn recommends I grain opium pills twice a clay to reliere pain, and warm liquid foods such as meat juice and milk in equal parts.

\section{Abdominal Dropsy or Ascites.}

Etiology.-This disease is sometimes called chronic peritonitis. It is characterized by the accumulation of a large quantity of liquid in the abdominal carity. In some cases the abdomen becomes so distended that it nearly or quite tonches the ground when the bircl is standing. Salmon says: "If examined by slight pressure of the hand the swelling is found to be soft and fluctuating; it will yield in one place and canse greater distension at another. 'That is, it gires the sensation of a sac filled with liquid."

Abrominal dropsy may begin with a mild case of peritonitis which has continucd for a long time without becoming serions. In foung chicks it is said to be due to an ansmic condition producel by bed feeding and insanitary conditions. In ofler bircls it may also result from this same canse or may be due to some olstruction of the venous circulation either by a tumor or by some structural disease of the abdominal organs.

Diagnosis.-The most marked symptom, of course, is the cularged. flabby abdomen. Salmon says: "Fowls affected in this way are dull. disinclined to move, generally feeble with pale comb and diminished appetite."

Treatment.- "Treatment of this condition is not profitable. but in special cases, stimulating diet with consinlerable animal food, tonics and diuretics, may be tried. Iodide of putassium 
or iorlicle of iron in closes of I grain is particularly inclicated." (salment.) Tapping with a hollow needle or trocar through the skin and muscles of the ablomen and allowing the fluid to escape is also recommended. It will usually be found more profitable to kill the bird. 


\section{CHAP'ER XI.}

\section{INTERNAL, PARASITES.}

Fowls are often seriously infested with internal parasites. The most important of these are various worms living in the alimentary canal. In popular usage these are spoken of simply as "worms." Various other internal parasites as the gape worm, the air sac mite, etc., are described in other sections of this book. The present discussion will be confined to intestinal worms.

Regarding these Robinson says: "Worms in small quantitics inllabit the digestive organs of all fowls and animals without cansing them serions inconvenience. It is even maintained by some authorities that in limited numbers these parasites are beneficial, though in just what way they are beneficial I have never seen stated, and it seems more reasonable, in the present state of knowledge of the subject, to claim no more than that when not too numerous they do no perceptible harm. Worms are contagious in that they are transmitted from fowl to fowl. probably ahways indirectly by being deposited on the ground by one fowl and taken from it by another; but if it is true as stated that worms in small numbers are always present. contagion is not required to accomnt for their increase to tronblesome numbers in many members of a flock simultaneonsly. The more reasonable assumption in the premises is that all these fowls alike were in a condition favorable to an excessive development of the parasites. 'lhis is a phase of the question on which the literature of the subject has done nothing-yet it seens to be the all-important point to determinc."

Diugnosis of Horms in Gencrul.-Accurate diagnosis of worms in the intestines can be marle only by finding the worms. in the droppings of the fowls. Fowls affected with worms to any great extent frequently show the general symptoms of clullness and depression. Birds that are suspecter of being affecterl with worms should be shut up in a conp and given a dose of 
some vermifuge or a purgative dose of Epsom salts. If careful observation of the droppings are made at frequent intervals the worms, if present, can usually be letected in this way. This is not, however, an infallible test. Regarding further measures kobinson says: "If efforts to secure evidence from the living fowls of the presence of worms fail, and the poultryman is at a loss to account for the trouble with his fowls, a suspected fowl slould be killed and examined, and if this is still insufficient, the case should be taken to a competent veterinary. It is of greatest importance that the facts in such cases be learned and proper treatment given, for whether the worms cause the trouble or conditions exist which favor their increase, the situation is full of danger to the keeper of a flock in which serious trouble is associaterl with worms; and while I do not wish to unnecessarily alarm anyone, the fact that in recent years worms in epidemic form have put a number of poultry plants out of business, should be stated as a warning to poultrymen troubled with unidentified diseases presenting symptoms which might be associated with worms."

The principal parasitic worms which affect the digestive tract of fowls may be grouped into three classes as follows: Tape worms, round worms and flukes.

\section{Tape Horms.}

Tape worms have long been known to infest domestic poultry. Occasionally serions ontbreaks of the tape worm disease occur in various parts of the country. These outbreaks are usually confined to comparatively small areas and are perhaps more common in the southern states.

Eitiology- The tape worms of poultry, like those which infest man and the domestic animals, are long, flat, segmonted worms. (fig. 6.) The anterior end of the animal possesses a number of honks or suckers by which it attaches itself to the walls of the intestine. Back of this head the entire animal consists of a long series of segments or proglottids. The segments nearest the head are the smallest and it is at this region that new segments are constantly being formed. 'The farther from the head they get the larger the segments become. Towards the posterior end of the worm the segments develop sexual organs and later become filled with eggs. As soon as the eggs are 


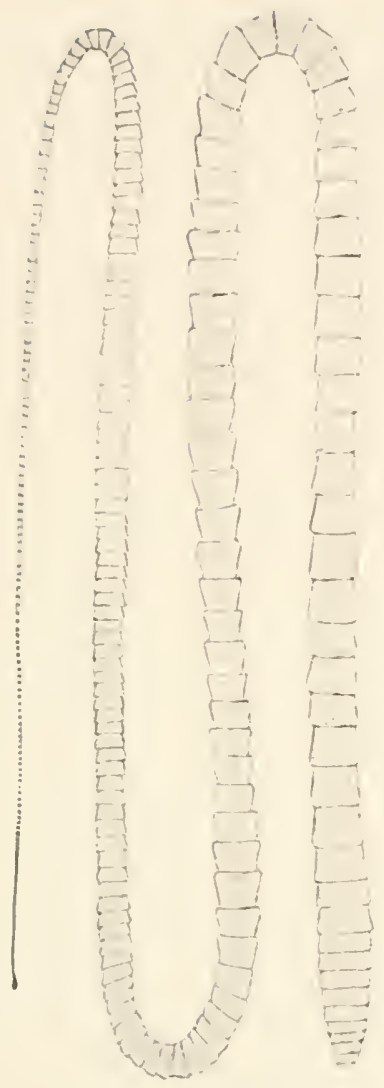

Fig. 6. Drepanidotacnia in fundibuliformis a tape worm of the fowl. ( $\mathrm{Ai}$ ter S(iles).

fertilized and mature the segrment containing them drops off and passes to the exterior with the feces of the lrost. Each segment of this kind contains thousands of eggs.

If these eggs are to develop tarther they must be swallowed by some internediate host (as a worm, snail or insect). The egg then hatches into a 6-hooked embryo which bores its way from the intestine into the body cavity of the intermediate host. It here develops into a larval form known as a cysticercoid. When the intermediate host (worm. smail. etc.) is eaten by a chicken this larva continnes its development and forms an adult tape worm. Thus there are two stages in the life cycle of a tape worm: that in the adult host and that in the intermediate host. Each species of tape worm, of which there are a great many, has its particular host, both intermediate and final.

According to Stiles (Bur. An. Ind. Piul. I 2) there were up to Iso6. 33 species of tape worms recorded for poultry. OÁ these I I are rocorlerl as occurring in chickens. The complete life history is known for only a few of these. Regarding the tape wormi of clickens. Stiles (loc. cit.) says. p. I 3 : "(They) are know'n to becume infected with one tapo worm througl eating slugs (Limax). They are supposed to beconne infected with a second through eating snails (Helix) : by a third through eating flies and by a fourth througl eating earth worms."

There seems but little need to give a lescription of the different species of tape worms found in chickens. The characters by which they are distinguished from each other are ton minute and imvolved to be of use to the poultryman or farmer. If anyone is having trouble with tape worms in poultry the lest thing 
to do is to send a portion of the intestine containing the worms to the \%eological Division, Bureau of Animal Industry. U. S. Department of Agriculture, Mashington, D. C. In this way the worns will be islentified and any specific remedies will be recommended.

\section{Nodular Touiusis.}

Stiles says. P. 15: "At least one specie, of tape worm ( $\mathrm{Da}$ f'anca tetrayona) causes a serious nodular disease of the intestine of chickens which upon superficial examination may be easily mistaken for tuberculosis." Moore says (Bur. An. Ind. Circ. No. 3. 1895):

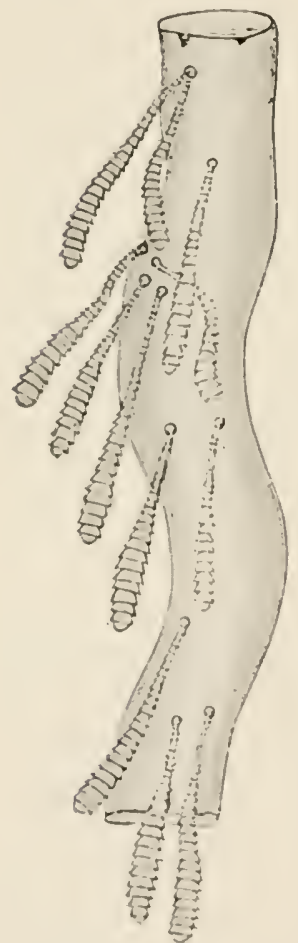

Fig. 7. Intestine of a fowl turned wrong side out to show tape worms in nodular taeniasis. After Pearson and Warren).
"Tuberculosis is the only known disease for which this affection is liable to be mistaken, and it is of much importance that the two diseases should not be confounded. 'The diagnosis has not in my experience been difficult, as in every case the attacherl tape worms were readily detected upon a close examination of the intestinal contents, or of the mucous membrane of the infected portion of the intestine. However, the worms are quite small and could easily be overlooked in a hurried or cursory exannination. In case of dombt, if the affected intestine is opened and the nuncons surface washed carefully in a gentle stream of water, the small worms will be observed hanging to the nuncous membrane. This discovery, in the absence of lesions in the liver or other organs. would warrant the diagnosis of the tape worm disease."

Diagnosis._The symptons of tape worn disease are not specific. The gencral symuptoms are similar to those of other worms (cf. p. 75). Regarding the symptoms of tape worms Stiles quotes the following from \%ürn: "If numerous tape worms are present in the intestine of young or old fowls a more or less extensive intestinal catarrh develops. corresponding to the greater or less number of parasites present." 
"The intestinal catarth shows itself, especially in chickens and geese, as follows: The sick animals become emaciated, although the appetite is not especially disturber. At times the appetite is even increased. The droppings are thin, contain consilerable yellow slime, and are passed in small quantities but at short intervals. The poultry raiser must direct his attention to these thin, sliny, and often bloody droppings, for if any treatment against the tape worn is to be mulertaken, this must be lone as early as possible. In observing the droppings it should be noticed whether tape worm segments or eggs are present. The eggs can be seen, of course, only with the microscope."

"After a time other symptoms develop. 'The sick animals become dinll and listless, remain apart from the rest of the flock -the feathers are ruffled and the wings droop, the appetite is lost and the birds allow themselves to be easily caught. Although it was stated that in the beginning of the trouble the appetite is not disturbed, the sick animals develop an intense thirst for cold water. When it rains they run under the eaves in orler to catch water, and in winter are eager for ice water."

Since the examination of the feces for tape worm segments is rather unsatisfactory for the farmer or poultryman, Stiles says that "The best method for the farmer to follow is to kill one of the sick clickens when he suspects tape worms and to cut out the intestine. He should then open the intestinal tract from gizzard to anns in a bowl of warm water, and look for the parasites," (Cf. fig. 7 ). Finrling the worms in the alimentary canal is the only certain diagnosis of the clisease.

Treatment.-The chief dings used for tape worms in fowls are: Extract of male ferm, turpentine, area nut, powered kanala, pumpkin seed, pomegranate root bark and Epsom salts. The following extract from Salmon gives the principal methorls of treatment and the doses: "One of the best methols of treating tape worms in fowls is to mix in the feed a teasponful of powdered pomegranate root bark for every 50 head of bircls. In treating a few bircls at a time it is well to follow this medicine with a purgative dose of castor oil ( 2 or 3 teaspoonsful). According to Zürn, powelered arecal nut is the best tape worm remedy for fowls, but he states that turkeys are unfarorably affected by it. It may be given in closes of 30 to 45 grains mixerl with butter and mafle into pills. Nale fern is also a very effectual remedy and may be used in the form of powder (dose 
30 grain- 10 , dram) or of liquid extract (dose is to 30 drops). It shomla be given in the morning and evening, before feeding. Oil of turpentine is an excellent remedy for all worms which inlabit the digestive canal. It may be given in the lose of $\mathrm{I}$ to 3 teasponninls, and is best arministered by foreing it through a smill flexible catheter that has been oiled and passerl through the mouth and resophagus to the crop). This medicine is less serere in its effects if cliluted with an equal bulk of olive oil, but, if it fails to destroy the parasites when so diluted, it may be given pure. The method of administering medicine by depositing it directly in the crop can be advantageonsly used with many other liquid remedies, and should be adopted in all cases where it is important to have the full dose in the stomach in a short time. It cloes away with the uncertainty attending the giving of medicine in the feed or drinking water. and with a little practice is more expeditious than making and giving pills. The open end of the catheter may be inserted into a rubber bulb having one opening. Just sufficient air should be expelled from the bulb, so that the dose of medicine will be suckerl up without

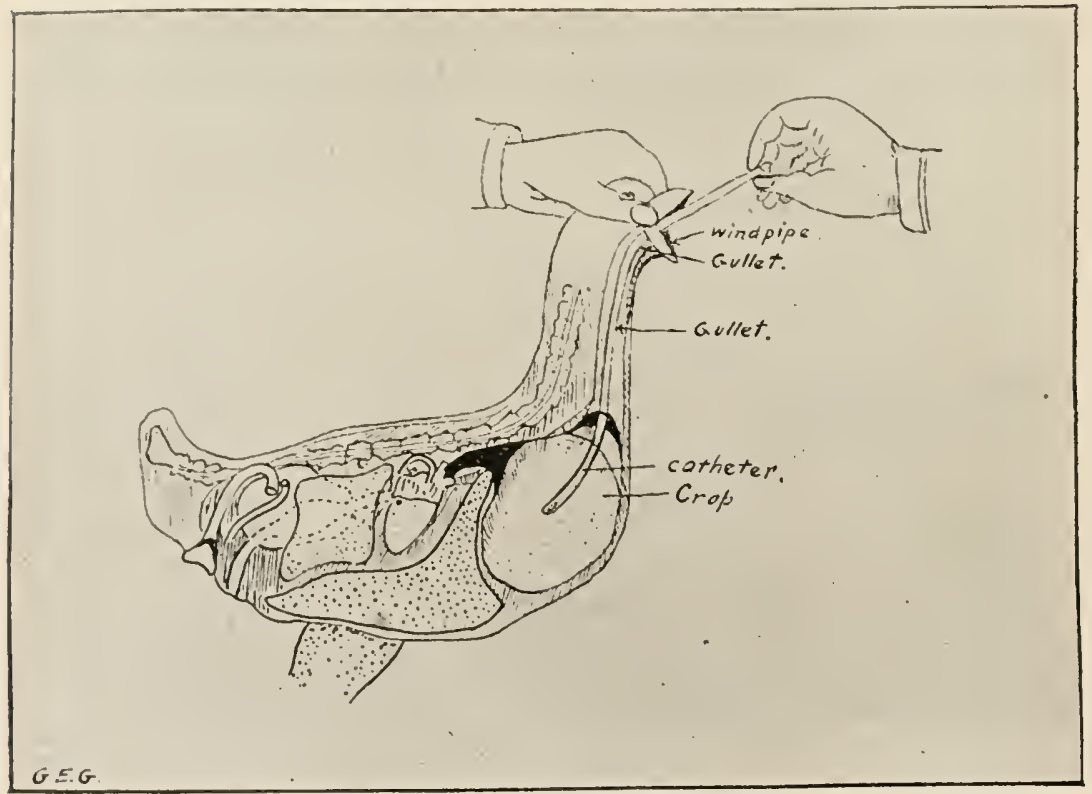

Fig. 8. Sketch showing method of introducing turpentine directly into crop. (From Gage and Opperman). 
being followed by much air. The birit's head is then lorenght in a line with the neck, which is extended, the eatheter is parent earefully to the erop, when a slight pressure on the bulb forces ont the medicine, and the instrument is withdrawn. The operator shonld be stre that he avoids the trachea."

Nore recently Gage and Opperman* have found Epsom salt and turpentine a very effective rencely for Nodular 'Treniasis. After careful consideration of the data they conclucle that "fo to 50 grains of Epsom salts is sufficient for an adult fowl in order to clean ont the intestinal tract so that the bircls may take food. Then the turpentine should be introduced" as directed above. For younger birds the dose of salts should be proportionately less. In fowls from 6 months to 2 years old the salts are best given by dissolving in water and giving each fow this liquid. For younger chicks the saits may be dissolved in warn water and used to moisten the mash or feed.

Preicution.-The following statement by Salmon gives some of the chief prerentative measures: "Parasitic infestation of the digestive tract should be guarded against by hygienic measures so far as possible. One of the most important of these measures is to move the fowls mpon fresh ground every 2 or 3 years, or certainly in all cases where such parasites are frequently observed in the intestines of the birds. Another practical measure. which may be adopted at the same time, is to remove the excrement daily from the houses and destroy any parasites or their eggs which may be in it, by mixing it with quick lime or saturating it with a to per cent solution of sulphuric acicl. The acid is cheap. but requires that great care be taken in diluting it, owing to danger of its splashing upon the clothing and flesh and causing severe burns. It should always be poured slowly into the water used for dilution, but on no accomnt should water be poured into the acid as it will cause explosions and splashing."

"When treating diseased birds these shonld always le isolated and confined, and their droppings should either be burned or treated with lime or sulphuric aciel as just recommended. Withont these hygienic measures, medical treatment can only be partially successful."

Stiles says: "An extermination of slugs will insure immunnity against Davainca proglottina, but no precise directions can be

*MId. Agric. Expt. Stat. Bul. I39. 1909. 
given ts prevent chickens from becoming infected with other tape lormes luntil the life history of these parasites is better understond. It will be well, however, to keep the chickens houserl in the morning until the sum is well up and the ground is (liy. for they will thus be less likely to meet with the supposalile intemediate hosts of other worms."

\section{Round Horms.}

Rumnd worms can be found in the intestine and especially the ceca of almost any fowl. They are much more common than the tape worms. Normally the round worms cause no serious trouble to fowls. Under certain conditions, however, they may become so numerous as to

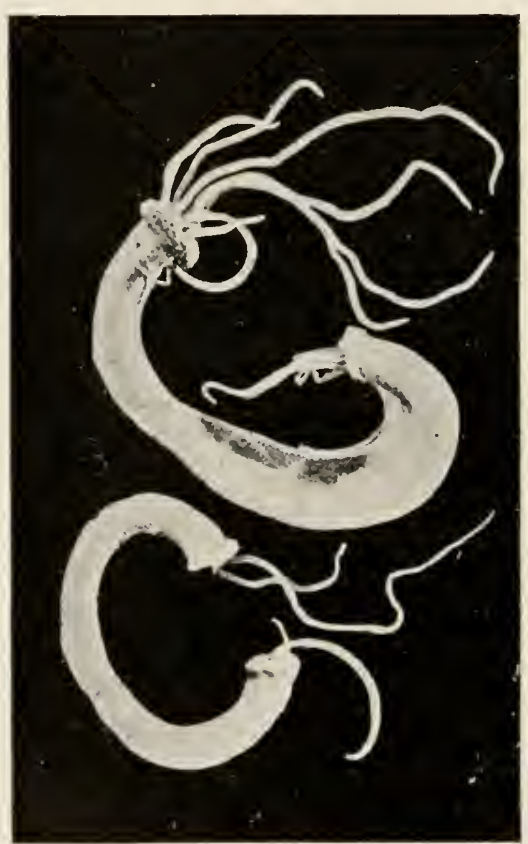

Jiig. 9. Worms protruding from a section of the intestine of a fowl. (After Bradshaw). be a serions menace to the flock. At such times they have a decided effect on the digestion; the irritation of ten causes diarrhea. When in large numbers, they sometimes become rolled and matted into a ball which may cause complete stoppage of the intestine.

The round worms are white in color and vary in length from $\mathrm{I}-3$ inch to 5 inches. The head end is sharp pointed, while the tail end is more blunt. Round worms are seldom passed in the feces unless present in very large numbers. When a worm is passed it soon dies in the droppings or is eaten by another fowl.

Dispharagus spiralis, a small worm about $\mathrm{I}-3$ inch in length, is often fotmd in the oesophagus and occasionally in the crop or intestine. 
Dispharayus nasutus, about $1 / 4$ inch long. occurs in the walls of the gizzard of fowls. It sometimes becones so numerous as to cause serious loss.

Hitrakis perspicillum. from $\mathrm{I} / 2$ to 3 inches long. is very common in the intestines of fowls. They sometimes become very numerous and may become rolled into rather large balls which obstruct the passage of the food.

Several other species of the genus Heterakis also infest fowls and other poultry.

Diagnosis.-The symptoms of round worms are similar to those of all worms (cf. p. 75). There is evidence of indigestion. The comb becomes pale and there may be diarrhea.

Treatment.-The remedies mentioned on p. 79 for tape worms are also useful for round worms. The remedy most commonly advised is to give 2 grains santonine for each bird. Dissolve this in water and use to mix the wash. As recommended on p. 79, all droppings should be collected and examined, also put ont of reach of the bircls.

Vale recommends the following: "Beat a new laid egg with I tablespoonful of oil of turpentine and mix thoroughly by shaking. Give a teaspoonful of the mixture

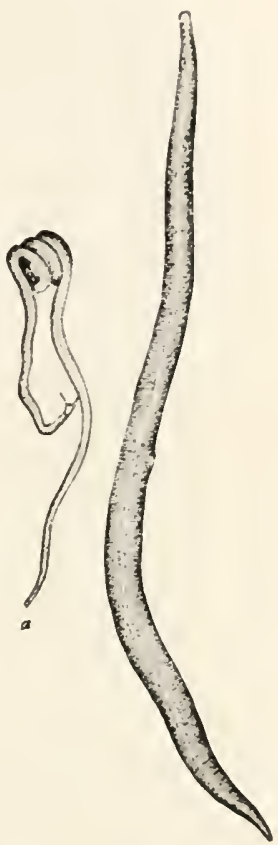

Fig. Io. Heterakis porspicillum.

a, male. b, iemale. x2. (From Salmon). night and morning for a few days; or divide $1 / 4$ of an ounce of areca nut in powder, into 4 parts, and give I part each morning, fasting. with a dessertsponful of sweet oil 2 hours after each powcler."

\section{Flukes.}

Flukes or trematode worms are small, flat and usually ovalshaped. Fig. I gives a fair idea of the appearance of these parasites. 


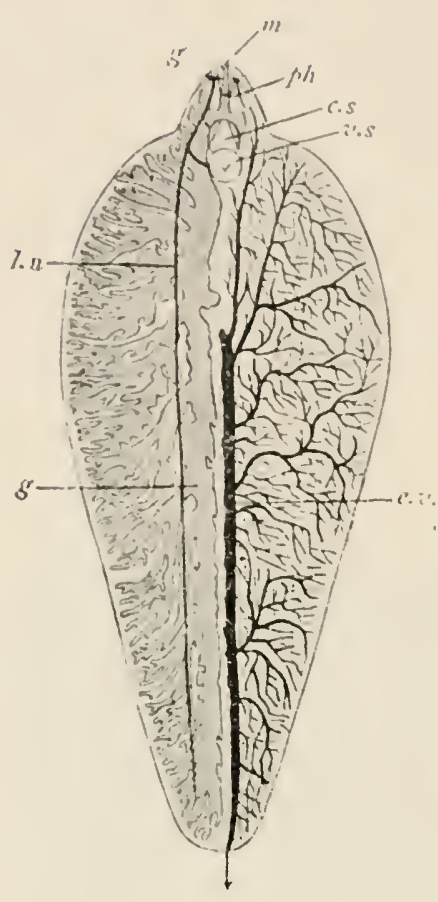

Fig. II. Trematode worm or fluke showing internal structure. (From Thompson after Sommer).

Regarding these parasites in ponitry, 'Theobald (Parasitic Discases of Ponltry. London) says: "The Trematode worms or Filukes found in the fowl are 3 in number. One is found in the egg (Distoma oratum), the others in the resophagus and intestines."

"The Fluke found in the oesophagus of the fowl is known as Cephalogonimus pellucidus, a transparent redlish fluke about 9 mm. long. These were found by Von Linstow and Railliet. In the intestines Netunann cnumerates 7 species, namely, Notocotyle triscrialis Distome o.rycephalum, Rud., D. dilatatum, Miriam, $D$. lincarc, Zeder, $D$. ozatum, D. armatum, Molin, and Mesogonimus commutatus, Sons. These, however, are not all distinct; dilatatum is undoubtedly the same as ory'cephalum; armatum is also probably the same."

"None of these Trematode worms are of any pathological importance, although, as is well known, they often cause serious malarlies in other animals. All the Flukes that have two hosts underg, a complicated metamorphosis, the early stages always taking place in some water-molluse. Those found in Gallus domesticus have not had their life-histories worker out." 


\section{CHAPTER NII.}

\section{DISLASES OF THE RESPIRITORY SYSTTM.}

Anatomy and Physiology.

The respiratury organs of birds are the nasal passages, the pharynx, larynx, trachea, lungs and air sacs. The form and general appearance of the lungs and trachea are shown in fig. I 2.
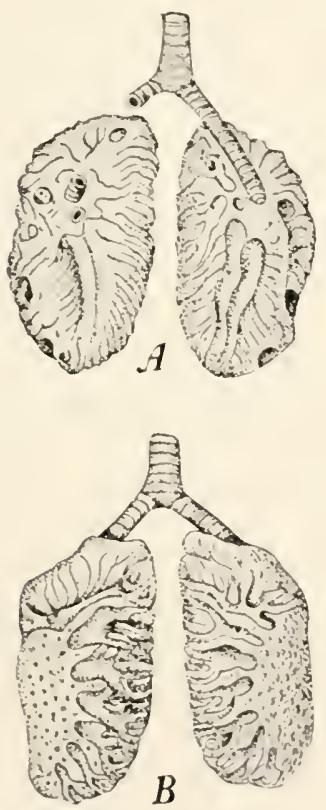

Fig. 12. Lungs of a bird. A, lower surface. B, upper surface. (After Salmon).

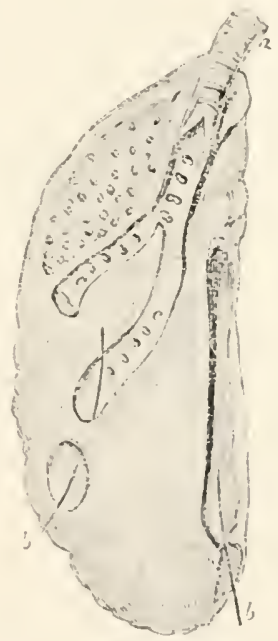

Fig. I3. Right lung of a groose. $t$, primary branches. $\mathrm{b}$, and $\mathrm{b}^{\prime}$, openings into abdominal and thoracic air sacs. c, c, secon d a ry bronchi. (After Owen1).

The respiratory apparatus differs somewhat in structure and function from that of mammals. As in manmals the trachea (wind-pipe) divides into the primary bronchi, cile passing to cach lung. In birds these bronchi do not divide aird subdivide 
as in mammals but each passes to the posterior end of its lung and where it opens into the abdominal air sac. This relation is shown in fig. 13.

In the lung the primary bronchus gives off branches (secondary bronchi) some of which end blindly (cf. fig. 13). The secondary branches give off branches (tertiary bronchi) all of which encl blindly (cf. fig. If). This tubular system makes up the air-containing portion of the lungs. It is imbeded in a net-work of almost naked blood ressels which make up the spongy tissue of the lungs (cf. fig. 14). The aeration of the blood takes place through the walls of these ressels. The relations of this tubular system of the lungs are shown in fig. It.

The air sacs are very large, thin-walled sacs which open into the bronchial tubes as clescribed. They function chicfly as reservoirs of air so that fresh air is supplied to the lungs twice during each breath. The air passes through the lungs into them during inspiration and during expiration the lungs are filled with the air forced back from the sacs. Some aeration of blood takes place in the sacs and they also help to reduce the relative weight of the body. In addition to aeration of the blood, the respiratory apparatus eliminates most of the waste moisture of the body and is, therefore, the temperature regulator. In mammals this function is performed by the sweat glands and the secretion of the kidneys. Birds have no sweat glands and the secretion of the kidneys contains relatively little moisture.

The air passages are lined with mucous membranc and this membrane is the seat of several diseases. Diseases are easily transferred from one part of the respiratory system to another, since the passages and also the lining membranes are continuous from the nostrils to the air sacs. There are also diseases of the vascular part of the lungs. Some of these diseases are caused by unfarorable conditions as exposure to cold, draughts of air, or moist air or to improper food. Others are due to specific organisms. Most of the latter are contagions. Exposure to unfarorable conditions also reduces the ability of the birds to resist infectious diseases. 
Catarrh-(Simple Catarrh; Non-contagious (atarrh; (Cold.)

One of the most common diseases of the air passages is catarrh $(\operatorname{col} l)$. It is often hard to distinguish this discase from early stages of roup and diphtheria. The characteristic symptoms of the latter disease should be carefully looked for. lest the flock become infected with a dangerous contagious discase. In cases where there is a suspicion of either of these diseases it is better to isolate the sick birds. Catarrh is non-contagious. It usually affects only a few individtals in the flock. but in cases of exposure of the flock to the unfavorable conditions which cause the discase it may occur in quite a number of birds at the same time.

Diagnosis. Salmon gives the following description of the symptoms of this disease: " In simple, non-contagions catarrh, the affected birds are more or less (hull, they are disinclined to move, their appetites are climinisherl, they sneeze and the mucous membrane is thickened. causing some obstruction to breathing through the nostrils. There soon appears a thin, water discharge which later becomes thicker and glutinous, the eyes are often watery, the eyclisk swollen and sometimes held together hy a thick, viscid secretion. In very severe cases, the birds are somnolent, the plumage is erect and roughened, the nostrils are completely obstructed by the thick secretion, the breathing is entirely through the mouth and is accompanied by a wheezing or snoring somnd, the appetite is entirely lost. a thin liquid escapes from the month and the bird soon becomes exhatrsted and dies." 
Etiology. The catuse of catarth is exposure to cold, to (lratughts of air, to damp) atmorphere due to improper housing comlitions, or to wet weather. Weak stock or improperly nonrished birds are more likely to le affected by these conditions than strong, vigorous and well fed individuals.

Treatment. With strong, healthy stock it is usually only necessary to remove the cause. It is a good practice, lowever, to sive rel pepper (capsicum) with the food. Salmon gives the formula and dose of a tonic recommended by Megnin.

"Gentian root $\ldots \ldots \ldots \ldots \ldots \ldots+$ drams
Cinger $\ldots \ldots \ldots \ldots \ldots \ldots \ldots+$ drams
Sulphate of iron $\ldots \ldots \ldots \ldots \ldots$ drams
Iyposulphite of sodium $\ldots \ldots \ldots$ I dram
Salicylate of sodium $\ldots \ldots \ldots \ldots$ I dram

'These substances are to be pulverized and then thoroughly mixed. The dose is 3 to + grains a day for a medium-sized fowl. Its effects are stimulating and tonic."

In severe cases, the eyes, month, and nostrils may be washed once or twice a day with one of the following solutions which are given in order of preference:

I. Boracic acid 3 per cent solution.

2. Creolin I per cent solution.

3. Hydrogen dioxide mixed with equal parts of water.

4. Carbolic acid, 2 per cent solution.

Prognosis. A great majority of the birds recover in a few days if the catte is immediately removed. If the catise continues to act they may become worse and die, or the disease may become chronic and persist for a long time.

\section{Bronchitis, Croup.}

This clisease may follow catarrh as a direct extension of the inflammatory processes in the membrane of the nasal cavities and throat to the mucous membrane of bronchial tubes.

Diagnosis. 'The symptoms of bronchitis are the symptoms of a hard coll (severe catarrh) with rapid breathing and congh. It may be distinguished from a cold by the peculiar sounds made in breathing. In the early stages of the disease this is a whistling somnd made ly the passage of the air over the dry, thickened menbrane. As the disease advances mucus collects in the tubes and the breathing is accompanied by a rattling or bubbling sound. Under favorable conditions the symptoms do not tustally pass 
beyond this stage bnt soon disappear. In very severe cases the birds becone very sleepy and refuse to eat. The wings droop. The feathers are roughened and breathing becomes more and more difficult, until finally the birt dies. The less severe forms of the discase may become chronic while the symptoms of rattling breath and coughing up mucus may persist for a long time. In this form of the disease the birds appear well except for the above symptoms.

Etiology. When it follows a hard cold, bronchitis may be caused by an extension of the inflammation of the mucosa of the throat to the mucosa of the bronchial tubes. It may also be caused directly by exposure to cold, draughts, and dampness; or it may result from irritation of the mucous membrane cansed by inhaling irritating vapors, dust or foreign particles.

Treatment. Place the patient in a warm, dry. well ventilated but not dranghty rooms. Feed bread or midllings moistened with milk, and add to this food 2 grains of black antimony twice a day. A demulcent drink is often beneficial. A very good one is made by steeping a little flax seed in water. Other demulcent drinks are made by dissolving honey or gum arabic in water. This treatment is sufficient for mild cases. Salmon recommends the following treatment for severe attacks: "If the attack promises to be severe, it may sometimes be checked in the early stages by giving to drops of spirits of turpentine in a teaspoonful of castor oil and repeating this close after 5 or 6 hours. It should not be continued after there are signs of purging. for fear of exhausting the strength of the patient. In the very actute cases, where the whistling or snoring sounds with the respiration indicate a croupous form of inflammation, and where the gasping sh ms great obstruction of the air passage, relief may be obtained hy giving from 3 to 6 rrops of either the syrup or the wine of ipecac."

"Medicines should be administered very carefully in diseases affecting the trachea and bronchi, as otherwise they may enter the air passages and increase the irritation."

Prognosis. In the ordinary and chronic forms the birds usually recover. In the more severe forms a large per cent of the affected birds clic.

Influcusa (Epizootic, Gripte, Distemper).

This disease is mentioned by Woods as "a contagions germ 
discase checly association with roup." Robinson gives a brief statement of the diagnosis. treatment and prognosis of this disease as follows: "Priefly" stated, the srmptoms are of a sudden and serere cold, with high ferer, generally diarthea, and extreme debility. In very severe cases death may ensue within a few hours after the fowl is observel to be sick. Ustially the bad cases linger for a lay or two, while those that recover run for a week or Io days. Treatment the same as for bad colds."

Quite possibly this is not a separate clisease but is cither a severe form of cold occurring in many individuals of a flock which has been exposed to unfarorable, insanitary conditions, or is a mild form of roup.

Roup (Contagious Catarh. Diphthcria, Diphthcritic Roup, Canker).

Veterinarians have distinguished two diseases belonging to this general class of trombles as follows: (a) romp or contagions catarh when only catarrhal symptoms are present, and (b) diphtheria, diphtheritic roup and canker when diphtherial patches and false membranes are formed. The bacteriologists Moore. Harrison and Streit, consider these different stages of the same disease. Cary not only considers these as one disease but also believes that sorehead, chicken pox or cpithclioma contagiosum is also a form of this discase. These questions cannot be settled with the present knowledge of the causes of these discases. The evidence for considering roup and diphtheria as successive stages in the same disease seem much better than the eridence that sore-head is a form of this disease. In the present work sore-head is treated separately.

Roup is a disease of very great economic importance. It is widely distributed causing a large annual death rate, and also reducing the value and production of affected flocks since many birds contract the disease in a chronic form and become worthless for egg production or breeding. Such birds preserve the germs of the disease and this leads to fresh outbreaks when ever the flock is exposed to unfarorable conditions.

Diagnosis. Harrison and Streit* give a very good descrip.

\footnotetext{
*Harrison, F. C., and Streit, H., Roup. Ont. Agr. Coll. \& Exp'. Farm. Bulletin 125. Dec. I902, pp. I-I6.
} 
tion of the srmptoms of romp from carly to late stages. The following acconnt is quoted from their bulletin:

"The general condition of rotpy birch varies very much. After the first symptoms of the disease, which is ustrally a putrid catarrh from the nostrils, the affecter fowl is generally restless. separates from other members of the flock, becomes dull, cowers in the conner of the conp or mopes in the corner of the pen, with its head drawn close to its body and often covered with its wings."

"If there is a severe discharge from the nostrils or eyes. then the feathers upon the wings or back are likely to be smeared with it, stuck together. and after some time fall out; and the eyes often shut, the lids being glued together by the sticky discharge from them."

"A fowl in a slcepy condition, or moping as described, frequently arouses itself for a time, takes food, and especially water, and then gradually returns to the apathetic condition."

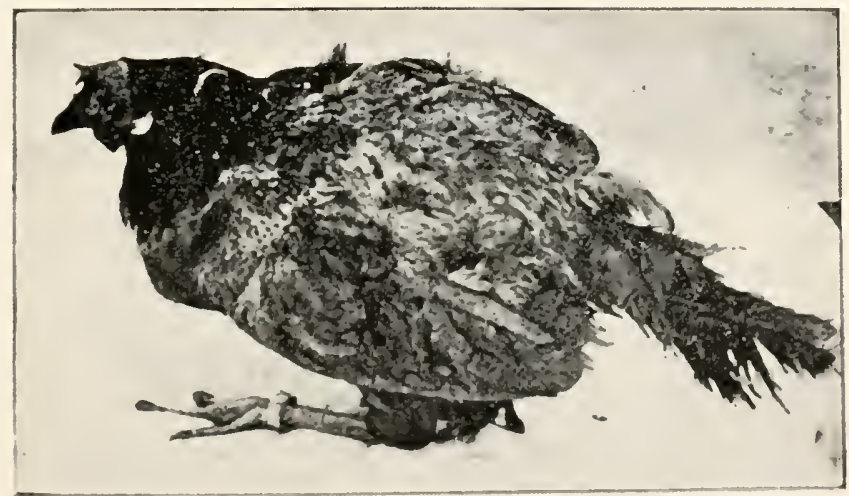

Fig. 15. Showing appearance of a hen a day before dath from roup. (From Harriso: and Streit).

"Many fowls having the disease in a chronic form keep their normal appetite for a long time, and seem very little disturbed physically. whilst others, especially when the face or eyes become swollen, lose their appetite, grow thinner and thinner, and fully become too weak to stand or walk around, when they lie down and die in a few days. During the last stage diarrhoea. with offensive yellow or green discharge, often sets in and canses death in a short time." 
"Many poultry keepers assert that roupy bircls show ferer" and it is certain that the head is often very hot. but the body temperature is normal, or only very slighty ligher than normal."

"Special Symptoms of Roup. liy the term roup we generally" anderstand a nure or less putriel discharge from the nostrils, which lasts for weeks or eren months. The disease often follows a common colkl, to which fowls, especially young fowls and those of the more delicate breeds, are much predisposed."

"In the first stages of roup, the birds often congh or sneeze, and the breathing is noisy, cansed by the partial closing of the air passages, which become blocked with the discharge from the nostrils. When the air passages are entirely closed by the discharged products, the fowl has to open its beak in order to breathe."

"Sometimes a yell wish cheese-like mass forms in the nostrils, growing quickly and pressing the upper walls of the nose npwards: and if this mass is removed, an meven bleeding surface is left, which forms a new cheesy mass in from 24 to 48 hours."

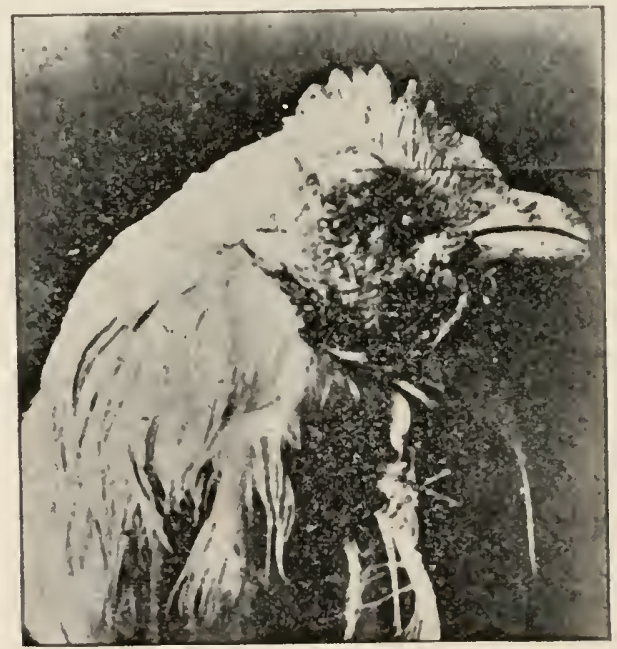

Fig. 15. Showing swelling of head in severe roup. (From Harrison and Streit).

"Whilst many roupy birds show only the above mentioned symptoms, others become more serionsly diseased. The face of roupy bircls is very often swollen, especially between the 
eyes and the nostrils; and this swelling. which is hot and sore, sometimes grows into a tumor as large as a walnut-generally firm and hard. (See fig. 16). A bird in this condition is frequently fonnd scratching at the tumor with its claws or wings, as if endeavoring to remove it. If the tumor grows on the inner side. towards the nasal passage, it forces the roof of the month downward, and the upper and lower beak are slowly pressed out of their normal position, so that the bird cannot close its mouth."

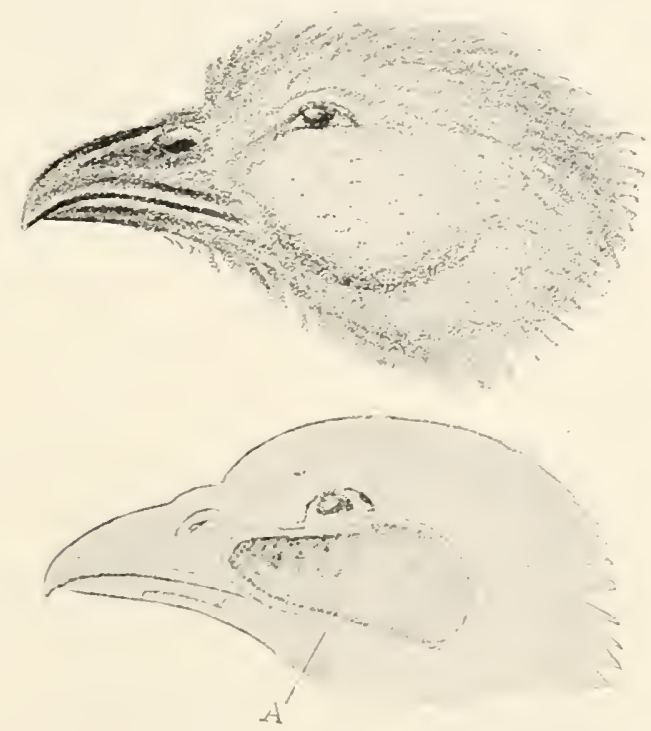

Fig. 17. Head of a bird. The lower figure shows the maxillo-ocular sinus, which opens into the socket of the eye and communicates with the masal cavities. The upper figure slows the roup tumor on the head caused by the filling of this casity with cheesy. pus. (From Megnin).

"On making an incision into the tumor, we find a solid, cheesy. yellowish matter, which may be puller ont like the root of a plant; but it usually has to be broken into small pieces in order to get it out. Around this mass, there is a more or less smooth. grey or brownish membrane that is capable of again forming a cheesy mass similar to what has been remored."

"The mass itself, when not attended to, often grows into the nasal canals, and blocks them up completely. Cienerally com- 
bined with the formation of the tmmor on the face, there is an affection of the eyes; or the eyes become discased without the preliminary discharge from the nose, in which case ponltry keepers speak of fowls as suffering from "roup of the eyes."

"Roup of the liyes. The first symptom of the eyes is generally an inflanmation of the eye-lids. These become red, swollen and hot: then the mucous membrane and glands of eres become inflamed and begin to secrete a liquicl-at first clear, and then of a grey, slimy, putrid character. which dries on the feathers at the side of the head, causing them to stick together or fall out. If the secretion is retained in the eye socket, it undergoes a change. becoming a yellowish, solid, cheesy mass of the same appearance as that foumd in the nasal tumor. 'This cheesy mass either forces the eye out of its socket, or the inflammation entirely destroys it. These cheese-like masses form in one or two days, and may reappear after many daily removals."

"All these affections, described above. may be localized on one side; but often both nasal passages and both eyes are affected at the same time."

"Combined with the symptoms of roup abore described, there often are patches of a greyish yellow exudation firmly adherent tc the month, throat, etc. These patches are called "false membranes," and on accomnt of their somewhat close resemblance to the membrane which is formed in human diphtheria, it has been thought by sone writers that the avian and human diseases are the same. Here, however, let it suffice to say that the weight of evidence is against this contention." 


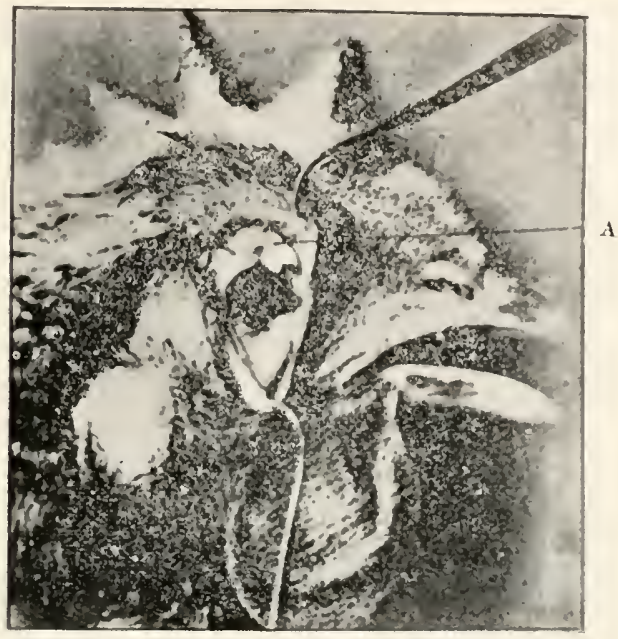

Fig. I8. Head of a fowl 22 days after inoculation with a culture of the roup bacillus. A.-False membrane. (From Harrison and Streit).

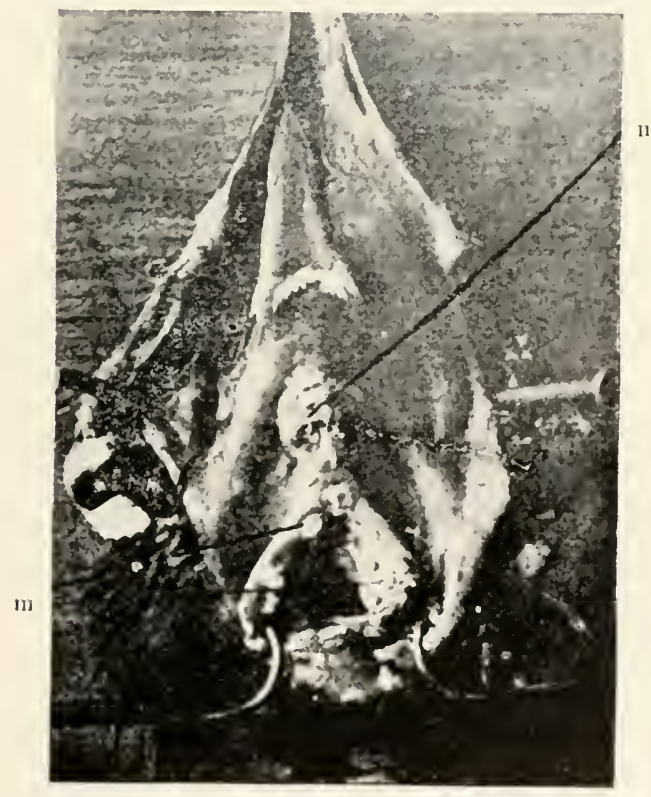

Fig. I9. 'Throat and botton of mouth with false nembrane $(m)$ I4 days after inoculation. (From Harrison and Streit). 


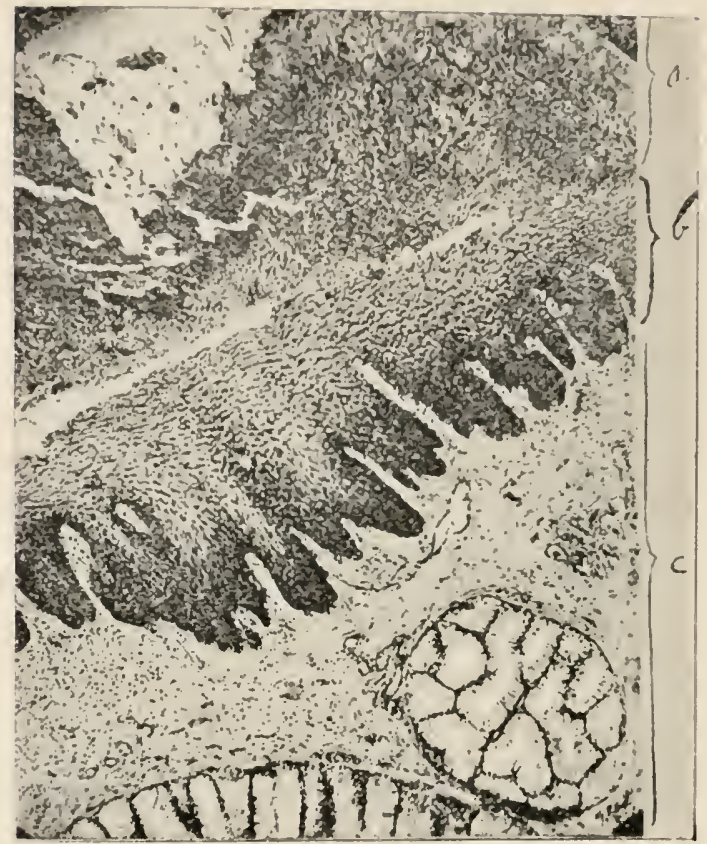

Fig. 20. A section of a false membrane of a roupy fowl. (a)-ialse membrane: (b), epithelitm: (c), sul) mucosa. (Firom Ifarrison and Streit).

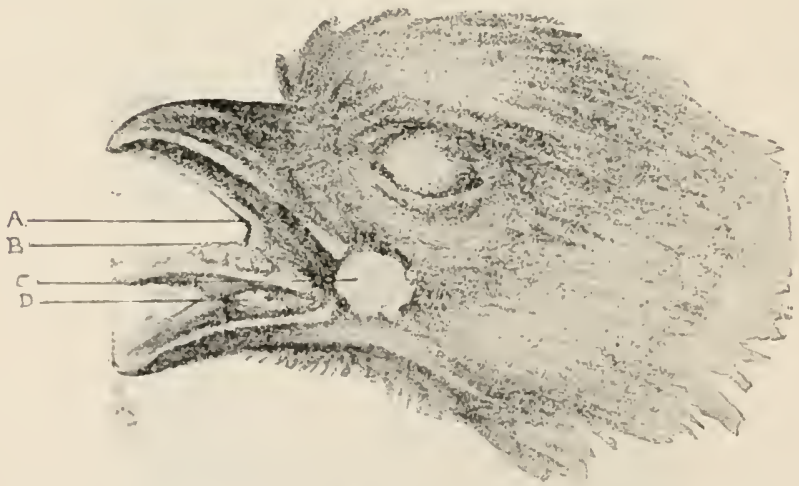

Fig. 21. Head of a bird with diptheritic roup affecting the mouth and tongue. A, B, C and D.-False membranes. (From Megnin).

"No may also point out that many poultry keepers who notice the false membrane on the throat and mouth of their fowls, 
regard the disease as quite different from the atarrhal form, and call it "canker," which is probably a popular form of the word "cancer."

"Whether the disease is characterized by false membranes, offensive discharges, or cheesy masses, the cause is the same, as we have many times experimentally demonstrated."

"At onc or several places in the month or throat, these yellowish, smooth or uneren membranes appear, and either remain small and disappear after a few clays or grow thicker, spread, and become firmly attached to the mucons membrane: and if they (the false membranes) are remored, an uneven, blecting surface is exposed, which looks like a true cancer."

"After the appearance of the membranes the adjacent submucous tissue sometimes becomes inflamed, and finally the growths are fonnd to be similar to those so often seen at the sicle of the face-containing solid cheesy matter in the center."

"Tilen the throat is blocked by these false membranes, the animal's breathing becomes abnormal, and the air passing through the throat produces loud noises. Gradually, the visible mucous membrane and the comb turn blue. and the fowl finally dies from suffocation."

"The Course of the Disease. The conrse of roup is usually of long duration. A simple, putricl discharge from the nose may stop in 3 or + weeks, and similarly false membranes may soon disappear; but generally the symptoms last for months. When the erelids become swollen and tumots appear, the case i: usually chronic. Affected birds may be better for a few days or weeks, and then become very weak again. Damp, colu weather nstrally intensifics the disease.

"It is well knnwn that fowls may be more or less sick from ronp for one or even several years and these birds should have the greatest care and attention. for they are generally the cause $n t$ new ontbreaks. Once introduced, roup may remain in a flock for many years. The first cold and moist niglits of the fall and early winter canse all kinds of catarrhs, which in many instances are followed by roup. Roup spreads rapidly in the winter time and may attack from to to 90 per cent of the fowls in a flock. Towards spring, the dicease grarlually disappears: during the summer months, a few bircli remain chronically affected; and then the first cold nights give the disease a fresh start." 
"Young fowls and fowts of the fine lneerls are especially liable to roup. While sone poultrymen mantain that birds once having suffered from roup never take the disease again, most of the experimental evidence tends to show that no acquired inmunnity exists, as sometines happens after other diseases. Some fowls are, however, naturally immme, and never take the discase. In the course of om own experiments, a white chicken which had never harl roup, was inoculated with repeated and large (loses of the roup germ, but without effect."

Eitiology. Several organisms have been isolated from the lesions of birds suffering from roup. Four of these have some claim to be considered the cause of the disease. These include 3 species of bacteria and one protozoan. There is also some evidence that the cause of the disease is an invisible virus. While the specific organism or organisms which cause the clisease are not certainly known its infections nature is well establisherl. It is probably carried from one individual to another in a Hock. by the particles of dried secretion in the air or possibly by the food and drink contaninated by the diseased birds. It may be introduced into a flock by the bringing in of birds from an infected flock, or by birds that have contracted the disease at shows. Possibly it is sometimes carried on the shoes or clothing of persons coning from infected yards or houses. While a source of infection i: necessary for the production of the discase it does not appear to attack bircls when the mucons membrane is in a healthy condition. It is most apt to attack birds that are suffering with catarrh. When a flock once becomes infected the birds which develop a mild chronic form of the disease serve as sonres of infection whenever expostue to cold and dampness causes catarrh in the unaffected birds. 'Thus in infected flocks an outbreak of roup usually follows catarrh caused by exposure and this fact has led some poultrymen to think that the disease may be caused directly ly exposure. In some flocks it appears annually with the cold damp weather of late autumm and breaks out again at every radical change of temperature and moisture conditions throughout the winter. Vigorous and properly nourished birds are better able to resist catarrh and consequently roup than those that are delicate and improperly ferl.

Treatment. The best treatment is prevention. The disease can be preventerl by stopping all sources of infection. Some things to keep in mind are: 
1. In introducing new birds always procure them from uninfected tlocks.

2. Isolate all new birds and all birds that have been exhibiterl at shows for 2 or 3 weeks to make sure that they do not develop the disease.

3. Exclude from uninfected house and yards poultry ancl all other animals. including men, coming from those that are infecterl.

4. Do not wse implements as hoes. shovels, etc. that have been used on infected prenises.

5. Keep the birds in a good hygienic condition, well nonrished and in dry well rentilated houses and roomy yards.

When the disease has been introduced into the flock careful precaution may prevent its spread.

I. Inmmediately separate from the flock any bird that shows symptoms of the disease.

2. Disinfect the yards and houses. A 5 per cent solution of carbolic acid may be used on the yards. Remove the litter from the houses and disinfect freely. This 5 per cent carbolic solution may also be followed by whitewash, or better use the cresol solution described in Chap. II.

3. Use potassimm permanganate in all drinking water. (See Chap. II.)

4. Keep watch of the flock so that any new cases may be isolated at once.

5. Burn or bury diep all birds that dic.

The disease is amenable to treatment but this treatment must be individual and requires a great deal of time. It must be contimued once or twice a day for quite a long time. It is therefore, very expensive and consecuently impracticable for ordinary stock. Moreover bircls apparently cured are likely to becume the source of infection for later ontbreaks.

Robinson well says: "I have cured many very barl cases, lut quit treating them years ago, hecause I found that as long as I cured roup I had nore roup to cure." No better adrice than is implied in this could be given. If the stock is only of orlinary value it is better to kill all birds that develop the disease. If the flock is barlly infected and the disease appears again and again when conditions faror its development, it is lectter to dispose of the flock and disinfect thoroughly, nsing new rnns when 
starting again. New stock may be obtained from minfected flocks or from incubator chickens raiserl on a fresh range.

In the case of valuable show hirds treatment may perhaps be arlvisalile.

IIarrison and Streit give the following methods of treating rollp:

"The germs of roup are not very resistant; they can easily" be destroyed when present in cultures, or somewhere outside the animal; but in the animal tissue, they are very difficult to kill. becanse they penetrate into the tissue; and unless this too is: killed, the germs continue living for a long time."

"Romp may be cured by remedies, if the treatment is careful and juclicions. Obstinately reappearing false membranes can be successfully treated by burning the diseased tissue with a strong acid (hyclrochloric acid 50 per cent to 75 per cent) or other caustic, such as silver nitrate. If the eyes and nose are attackerl. they have to be carefully washed, at least twice a day, with an antiscptic solution, such as 2 per cent boracic acid in a decoction of channmile flowers, or $1 / 2$ per cent solution (of corrosive sul)limate. Thus the micro-organisms are killer or at least, the cliseased products which are discharged are removed, and the irritation causer loy them; also the transformation into large cheesy masses is prevented."

"We had chickens badly" affected with roup of the eyes, which were cured with boracic acid and chamomile. On acconnt of the smallness of the nostrils and nasal canals, it is very difficult to get the antiseptic solutions into the nose and nasal carities; but it can be done with a small syringe. If this treatment is ton troublesome, then the nostrils, at least, should be washed and opened several times a day, to allow the secretions to pass away. WTe have treated chickens for 14 days by daily washing with a $2 \frac{T}{2}$ per cent solution of creolin and glycerine. After the washings, small plugs of cotton wool, filled with mixture, were placed in the nostrils and lachrymal duets. This remedy did not cure the roup), althongh the same mixture readily kills the roup bacillus in cultures in from 2 to 3 minutes. The greatest hindrance to a sure cure by remedies which have been used locally, is the ability of the germ to penctrate into the tissue and the many sccondary cavities of the nostrils which cannot be reached by the antiseptic."

"Another method of treatment which gives excellent results, 
especially in the early stages of roup, is the use of I to 2 per cent of permanganate of potash. Fowls are treated in the following manner: The nostrils are pressed together between thumb and forefinger in the direction of the beak two or three times. l'ressure should also be applied between nostrils and eres in an upward direction. 'This massage helps to loosen the discharge in the nostrils and eyes. 'The bird's head is then plunged into the solution of permanganate of potash for 20 or 30 seconds, in fact the head may be kept under the solution as long as the bird can tolerate it. 'The solution is thus distributed through the nostrils and other canals and has an astringent and slight disinfecting action. 'This treatment should be given twice a day and continued until all symptoms have disappeared."

"If there are solid tumors in the eyclids, they should be opened so that the skin may bleed freely. The cheesy matter should be removed and the surrounding membrane touched with a 5 per cent carbolic acid or silver nitrate solution. and then a cotton plug put in again to prevent the cavity from healing too quickly. We have cured chickens in this way in about a fortnight."

"As all these methods of treatment demand a good deal of time and care, they cannot well be used for whole flocks. but the more valuable fowls may be treated in this manner. Farmers and poultrymen should first try the permanganate of potash method of treatment as it is the easiest to employ."

"Food remedies infuence roup only by strengthening the fowls and assisting nature to throw off or conquer the discase."

Sanborn (Reliable Poultry Remedies) recommends the use of an atomizer to apply the disinfecting solutions to the nasal passages and moutl.

Je recommends the following solution for a spray for all the mucous surfaces:

lixtract of witch hazel, + tablespoons,

I iquicl carbolic acid. 3 (lrops.

Wrater. 2 tablespoons.

He applies the spray twice a day squeczing the bulb 5 times for each nostril and twice for the mouth.

Salmon recommends washing the carities of the nose and throat with peroxide of hyclogen, diluter 1 to 3 times with water. 
The birels which are being treated slowlel be kept in a dry, warm, well rentilated room with good nourishing food. The drinking water should be frequently changed.

Promnosis. In infected flocks this discase cansed a direct anmul lose of 10 to 15 per cent of the flock. Also many birds contract a chronic form of the disease which affects them for months or years. Careful individual treatment will save the lives of many hirds, but such treatment is economically inadvisalle execpt in case of very valuable birds.

\section{"Pip" (Inflammation of the Mouth).}

Robinson describes "pip" as follows: "Pip' is a term in very common use among poultry keepers, and applied chicfly to a symptom occurring in many cases of cold or fever when the nostrils being olstructed and the fowls breathing through the mouth the skin of the mouth and tongue become hard and dry, and a bony tip may form on the tongue by the hardening and drying of the skin of that member, this conclition being aggravated when catarrhal discharges adhere to the skin and dry and accumulate."

Fitiology. It would appear to be the case that the symptoms above described originated from different canses in different cases. The trouble may be due to specific infection, though a particular organism has not yet been definitely isolated as the cause. In some cases the symptom is apparently purely physiological, arising from a failure of the mucus-secreting glanels to function properly, owing to a lowered physiological condition.

Treatmont. The essential points in the treatment of this diseased conclition is first to treat the primary cause (cold. catarrh, etc.). In removing the scale or "pip)" gentle measures are to be followed, otherwise a raw surface likcly to ulcerate, will be left.

The following arlvice as to treatment, given by salmon, is execllent.

"In case of simply drying of the mouth, it is sufficient to moisten the tongue with a few drops of a mixture of equal partis of glycerine and water. In case there is redness of the membrane, or if the epithelium is leginning to separate, or if a deposit has formed, add 20 grains of chlorate of potash to each ounce of this mixtme. An excellent remerly for such cases is marle by dissolving 15 grains of boric acid in an ounce of 
water. linth of these solutions are harmless and may be frecly and frequently applied. When the epithelimm is separating, it should be kept moistened with the glycerine mixture and its detachnent may be somewhat facilitated by loosening it with a pin or the point of a penknife, but great care should be exercised, the sensitive tissues should not be totrhed and no blood should be drawn."

Prognosis. In and of itself "pip" is not a serions matter. It is, however, usually associated with other disorders of the respiratory system, which may be very serious. Regarding this matter Salmon says: "The exaggerated idea prevalent as to the langerous character of "pip," probably arises from its being associated with serious diseases of the respiratory organs and from the fatal results which follow the forcible tearing away of the (ried epithelium, leaving a blecting and ulecrating surface."

\section{Canker.}

Nembranes formed in diphtheritic roup are sometimes called canker, but there are frequently found cheesy patches on the mucous membrane of the month or tongue which are not associated with roup. These growths are frequently, at least, the result of a traumatic injury to the membrane. Male birds freanently have canker where they have been picked in the mouth wo other males when fighting. 'The growths are macle up almost cutircly of pus germs. These growths should probably be consiclered as suppurating wommels. An mhealthy condition of the mucons membrane of the mouth clue to digestive disorders is sometines accompanied by spots of canker.

$\triangle$ good treatment for canker is muliluted creolin applied with a cotton swal). The swab should be held against each sore for a short time. The whole surface of each patch should be treated. Another good treatment is to wash the sores with hydrogen peroxicle I part ancl water i part.

\section{Thrush.}

This term is also sometimes incorrectly applied to the false membranes of diphtheria lut there are at least two cases of true thrush on record. That is, in two cases microscopic exanination has shown that the patches, which in both these cases were in the lower part of the oesophagus and crop. were male up of spores and filaments of the fungus Succharomyces albicans. 
'This fungus causes thrush in chiltren and calves. This disease may also occasionally affect the month. It is impossible to distinguish it from other diseases caltsing similar formations except by microscopic examination. The treatment is the same ats for canker.

\section{Aspergillosis (Mycosis of the Lir Passages).}

This is a very common (liscase of poultry, often mistaken for tuberculosis. In adult fowls it is frequent cause of the condition known as "going light," while in young chickens it probably ranks next to white diarhoea as a lethal agent.

The discussion of this discase here relates primarily to adult fowls. Aspergillosis in young chicks is treated in Chap. XIX.

Diagnosis. Salmon gives the following account of the symptoms of this disease. "In the carly stages of the disease 110 symptoms are noticel, and it is only after it las progressed considerably that these become apparent. The affected birds (lo not follow the flock; they are very weak, scarcely able to stan 1, and consequently remain by themsclves and move about rery little. 'T'hey remain in a recumbent position, resting upon the sternum, are sleepy, and, if forced to rum, soon fall from exlianstion. The plumage is dull and rough, the wings are pendant, the colicls partly closed, the head tepressed. The respiraton is accelerated and accompanied by a rattling or snoring somel. particularly during the expiration, and becomes difficult and lalforecl, the bird opening its beak from time to time, in orcier to take a long inspiration. The temperature of the body is cievated, the thirst increased and the appetite is diminished or disappears. 'l'here is more or less eatarth of the trachea and bronchi, with enaciation and diarthea leading to death from exhaustion in from I to $S$ weeks. When the lisease is limited to the air-sacs of the interior of the body, emaciation may be the only smptom; lut when it extends to the bones there may be lanneness with swollen and painful joints."

"In examining the birds after death, the seat of the disease may be found in the trachea, bronchi, lungs, and various airsacs, and other internal organs. It is sometimes, though rarely, found in the nostrils and in the air-sacs of the interior of the bones. 'Two kinds of lesions are found. There nuy be tubercles resembling thos of tuberculosis. These are whitish or yel- 
lowish nodules varying from the size of a pinhead to that of a pea. They may be isolated or joined together in masses of considerable proportions. These tubereles are generally found in the depth of the tisstes, and eren in the marrow of the bones. On the mucons membrane lining the air-tubes and air-sacs, the secont form of cliscase prucess is seen. This consists of a nembranots formation, $1 / 8$ of an inch or more in thickness, which bears upon its surface a growth of the fungus. These nembranous patches are at first soft, but become firmer with age, and are yellowish or greenish in color. resembling a fibrinopurulent exuclate. 'They adhere closely to the mucous membrane which is there thickened and inflaned. 'The air-sacs are sometimes obstructed by these growths which may in time become cascons or even calcarcons. These changes may also be seen in the intestines, the mesentery, the liver and in other organs."

"The membrane lining the air-passages may, also, be found ulcerated, and the nlecrs may be either naked or covered with a growtl of the fungus."

"In the very acute and rapid cases, the lungs may simply show inflammation, or there may be formation of pus or abscesses in the lungs. kidneys, liver and spleen as in pyaemia or septic infection. In some of these cases there may be extensire hemorrhages, either locally or throughout the body, and these may constitute the only apparent alterations."

"I microscopic cxamination reveals the spores of filaments of the fungus in most of the lesions. Whether these are acute or chronic. The nature of the discase may consecpuently be determined by a post-mortem examination, lut the diagnosis is nuncertain and lificult during the life of the bircl."

Iitiology. The disease is caused by moulds of the genus Asfergillus which grow on the mucons membrane of the air passage. The funr parasitic species in orcler of their importance are Asperyillus fumigatus, Asporgillus nigrescens, Aspergillus glaucus. Aspergillus candidus. The appearance of one of these monluk, when greatly magnified is shown in fig. 22. 


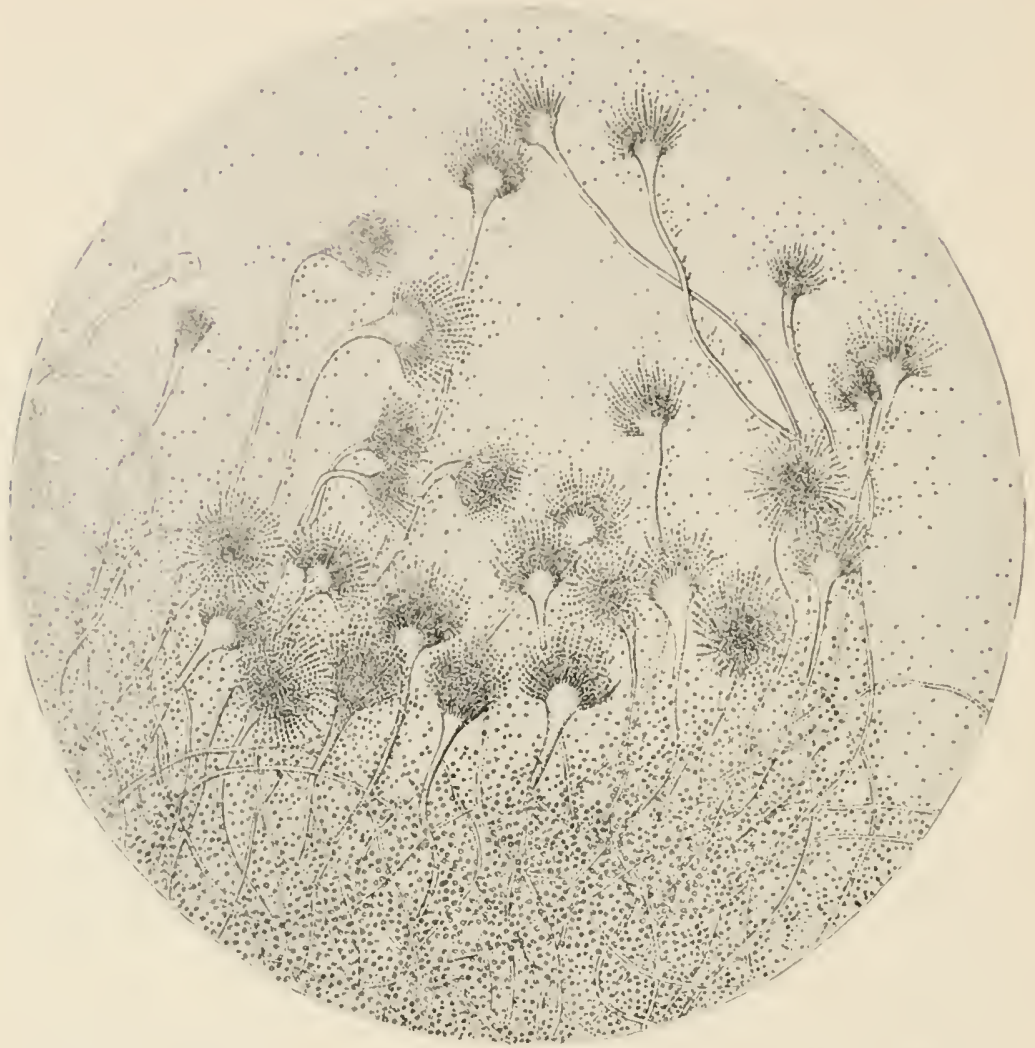

Fig. 22. Isporgillus jumigatus. Creatly enlarged. (After Mohler and Buckley).

These mondes an:l their spores ocenr on dearl organic material like straw, grain, ete. They are inhaled in breathing or swallowerl with the foxl. This leing the case the inportance of avo; ding musty litter, and monldy or musty grain of all kinds i. apparent. is with most other diseases the resistance of the incliviclual against infection is here an important matter. Some fowls will be able to stand musty litter and grain without any harm. While others will promptly develop aspergillosis. When once present in a llock aspergillosis is probably transmitted from generation to generation through the egress.

Troatmont. The discase is prevented by having clean, dry. well ventilated honses and avoilling the nse of monldy litter or grain. ligrous birds under sanitary conditions are fairly re- 
sistant. No medical treatment is known to be effective. Salmon gives a list of treatments which have been suggested and says "No form of treatment yet suggested, howerer, is very promising and the effort should be to prevent rather than cure." All birds that dic should be burmed or buriesl.

Prognosis. 'The disease in achult fowls is ordinarily not recognized as such until an affected bird comes to post-mortem at which time the prognosis is certainly extremely unfavorable. So far as concerns ridling a poultry plant of the disease, however, the outlook is favorable if energetic sanitary measures along the lines inclicated above are applied.

\section{Congestion of the Lungs.}

Congestion of the lungs is a distension of the blood vessels which make up the rascular portion of those organs. The pressure of these distended ressels may close the smaller air passages, or a vessel may burst, filling the bronchi. In either case the patient soon suffocates.

Diagnosis._The simptoms of this disease are difficult rapirl breathing. sleepiness and an indisposition to move. A blondy mucus sometimes flows from the mouth. The comb is lark red or bluish from lack of oxygen in the blood. Symptoms appear surleluly and death occurs within a few hours.

Etiology.-This clisease is caused by chilling the surface of the boly. This contracts the surface vessels and a larger volume of blod is sont to the internal orgais. 'The pressure on the small clastic ressels of the lungs is ton great and they either close the ar passages by pressing against them or the ressel walls are riptured by the internal pressure and the air passages become filled with blool. This disease most often occurs in demuder birds (lens during moulting or young birds which have failed to feather wut ) or small chicks which have been exposed to colit or allowed to run out in cold. wet weather.

Treutment.- The rapid course of the disease makes treatment inpracticable. Provention is the only cure. Pirds sbould le well nonrisherl with plenty of grcen food and shoulit be especially protected from cold and wet when monlting. Also (hicks which are in a stage betwcen (lown (chick) and jurenal feather need special protection. This disease often attacks broo? ch chicks and inclicates something wrong with the brooding. The cate should be immerliately sought out and remored. 
of consiclerable loss will follow from continued exposure of the flock.

I'rognosis.- This disease is ustually fatal in a few minutes or lenms after its srmptoms are noted. According to salnon the patient sometines rlevelops pnemmonia.

\section{I'ncumonia.}

This disease is a step beyond congestion of the lungs. The ressels are not only distended but liquid escapes through their walls and coagrulates in the air spaces. The lung of a chick dead of pnemmonia is lark colored and firm and heavier than water. I normal lung floats but a lung filled with this coagulated scrum sinks.

Diaynosis.- l'le symptoms resemble those of congestion of the linns. Salmon gires the following symptoms: "The breathing is rapicl, clifficult and painful. 'There may be conghing with discharge from the mouth or nostrils of thick, adhesive mucus, grayish or yellowish in color or tinger with blood. The bird stancls with ruffled plumage, drooping wings, head drawn in, and every appearance of severe illness. There is loss of appetite from the first, with thirst and constipation.

On examination of the lungs after death one or both of these wrgans are fotnd dark in color, engorged with blood and solidifiecl. The pnemonia may take either one of two forms. There may be what is known as broncho-pnemonia, in which case the irifammation affects more particularly the bronchi and the lung is not much soliclifierl. 'The bronchial tubes in this ease are more or less filled with thick mucus and exudate. In the other form, called cronpous pnetmonnia, the tissue of the lung is principally affected. It is then that the lung is soliclified by the filling up of the air-cells. A piece of lung so affected, if dropped intu a bucket of water, sinks to the bottom, while healthy lung tisste will float. The bronchial tubes and air-sacs are also in sr ne caces fillerl with a thick, yellowish fibrinous exuclate which litecki up thee alir-passages and becomes partly soliclified."

litiolong.- 'llue cause of pnemnonia in birds is not. known. calnum sus gests that it may be caused in bircls as the smilar drsate is known to be in some of the manmmals and man. Robinnen liriefy stmmarizes Salmon's statement as follows: "Te ats it is supposed that to proluce pnemmonia there must be II the the calleses that produce congestion of the lungs the agency 
of a germ, a species of bacteria, harmless when the lung is in normal condition, but harmful when conditions which causc congestion are present."

Treatment.-Ordinarily it will not be adrisable to treat this disease. A cure is unusual and incolic's such an anount of care and nursing as to make it a most unprofitable proposition. The following treatments have been advised by different persolls.

"1.- Keep the bird in a room of abont 70 degrees, with stean from boiling water if possible. Give erery 6 hours I grain phenacetin. and I grain sulpho-carbolate of zinc, mixed with bread crumbs enongh to make a pill. Feed on raw eggs and milk. Tincture aconite in the drinking water, or I drop every 2 hours in the egg and milk, will help control the hard breathing. If successful in saving the bird, build up its strength with tonics such as nux vomica or quinine. (Samborn.)

"2. - The bird should be immediately housed and kept warm. Counter irritation must be applied over the region of the lungs by wetting the skin under the feathers on the back with tincture of iodine. Stimulants should be administered 3 or + times a day-2 drops of spirits of camplior and to drops of brandy in a teasponnful of warm milk. Soft, mutritious cliet. especially clopped beef. is necessary. lieaten cogg and port wine is also useful. Three or + drops of chlorodyne may be given in a teaspoonful of linseed tea to relieve the more distressing symptoms; and ultimately. if the case progresses farorably, mineral tonics and cocl liver oil are favorable in establishing convalescence.' (Hill.)

"3.- Place bird in a warm room and cover with a piece of blanket, leaving the head uncovered that it may have plenty of air. Give linseed tea frequently in small quantities. To make this tea: Pour a pint of boiling water on an ounce of flaxsecd. and keep hot. but not boiling, for two hours. Strain to remore the seeds. The liquid may then be used as a drink. or medicines may be given in it. Dissolve enough nitrate of potash in the drink to give the bird about I grain 3 times a day. If the bircl $i=$ failing and becomes sleepy, with comb turning dark, mix ij drops of tincture of digitalis with I ounce of water. and sive Io drops of the mixture crery 2 hours. To give medicine use a medicine clropper. and be careful to avoid getting it into the 
air pamages. I: hen the bird begins to improve, grive a grain of yminime. or 10 drops of corl liver oil twice a ray. (Salmum. I "

\section{Tubirculosis.}

"This disease in birls does not usually affect the respiratory sintem. but is more commonly confined to the abdominal viscera, and is discussed with the diseases of the organs of alinentary tract (Chap. ${ }^{\circ}$ ).

$$
\text { The tir-Sac lite. }
$$

$\therefore$ species of mite (Cytodites mudus) infects the air-sacs and bionchi of poultry.

Diaynosis.- When the birds are not badly infested there are no extermal symptoms. If badly infested the bird may become ancmic and listless and finally die of exhaustion. Or. if the air passages are seriously obstructed by the collection of parasites and mucus there will be a rattling in the throat and coughing, ancl rleath may result from suffocation. The presence of the parasites is often found only on examination of rearl bircts. 'They appear as a yellow or white dust, each particle of which is a mite. If closely watehed the particles may be seen to move.

Etiology.-The mite probably enters the air-sacs by crawling in the nostrils and finding its way down the trachea and bronchi to the sacs. The parasites are able to live only a short time nutsirle the birl's borly. The mouth parts of these mites are modified into sucking tubes. 'They attack the mucous membranc of the air-sacs and bronclii. When the number of parasites is small they cause no serions inconvenience to the bird. When there are a large number

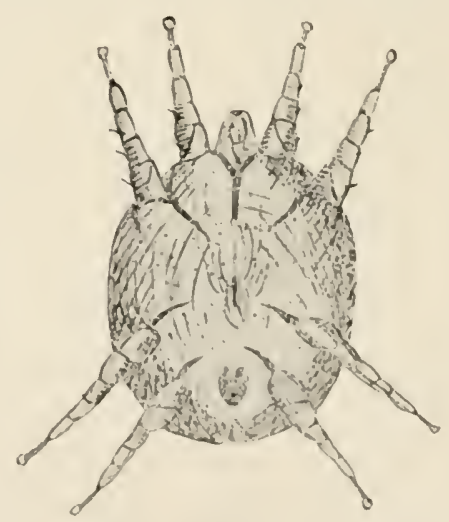

Fig. 23. Cytodites mudus. The air sic mite. (ircatly enlarged. (After Theobald). present they may cause inflammation of the membranc and secretiom of mucus or they may seriously olstruct the air passages. Troatment.-Treatment of infested birels is probably useless. Feeding sulphur with the foorl or compelling the birds to inhale 
the fumes of burning sulphur or burning tar or the steam of boiling tar water has been recommended.

If a flock is infested with this parasite it is best when posibible to start a new flock with incubator chicks ratical on a new range and carefully protected from infection from the old flock. ()r stock may be purchased from an munfested flock. birds with this parasite should not be bought or sold for breeding or laying purposes, as the Hock into which they are introduced will become infested from them. Since this parasite can not live long outside the birl's body, the houses, runs, ete. do not remain infested long after all the diseased birds have been remorecl.

I'rognosis.-I birel once infected is probalsly never free from the parasite but may live a long time little harmed by its presence. 


\section{1)ISEASES OI: THE: CIRCUHATORY SISTEM.}

Pericarditis Inflammation of the Pircardium, Dropsy of the lleart Sac).

This discase is often found associater with other diseases of the circulatory system and with discases of the lungs and airsacs and also with soreness of the joints.

Diagnosis.-A differential diagnosis of this discase during life i.s not usually possible. Salmon gives the following symptoms: "There is great weakness, difficult breathing. the head being thrown backwarls, and the breath drawn through the month in order to olitain sufficicint air. If forced to run the bird soon falls. In a case obeerved by Hill there was tumultuous action of the heart and occasional spasms." Examination of a bird dead from this disease show's the heart sac full of serous liquicl and sometimes the carity is divided by false membranes which may attach to the heart as well as to the pericardium.

Fitiology.- The causes of this inflammation are not known. It may result from exposure to cold or dampness.

Triatmint.-Treatment is impossible since the disease can not be diagnosed until after death. Successive cases in the same flock indicate exposure of the flock to cold or wet weather or to confining the birds in insanitary houses. These conditions should be remedied. Salmon also recommends in such cases $" 2$ to + grains of bicarbonate of sodla to cach bird laily in the lrinking watcr."

\section{lindocarditis (Inflanmation of the Internal Membrancs of the Heart).}

In the examination of dead birds it is sometimes found that the membrane lining the heart is reddened and coagulated lymph may allhere to it. Little is known of this clisease in fowls. It camnot be distinguished from pericarditis except by an examination of the heart. The canse and treatment suggested for that disease probalsly apply equally in these cases. 


\section{Myocarditis diptheritica.}

Accorling to 7.ürn. Bollinger has described a bacterial disease of the heart and blood vessels of fowls and pigeons. 'The disease is caused by a bacterinu which resembles the bacterium of roup. The discase attacks the lining nembrane of the heart and blood ressels, cansing inflammation and the breaking down of the tissue. It especially affects the valves of the heart and aorta, where romul or oval colonies of the bacteria are found on the membrane. In these patches fibrin and red and white corpuscles are mingle: with the organisms. The walls of the small vessels of the lungs, liver. spleen, kidneys and intestines are also affected. The liver. spleen. and kidneys are enlarged. The bacteria are numerous in these organs as well as in the blood.

Little is known of the frequence of the occurrence of this disease an:1 nothing of methods of treatment.

\section{Enlargement of the Heart (Hypertrophy').}

The heart of a fow is sometimes enlarged. According to Cadeac this enlargement most frequently affects the right side of the heart. The muscle may be fatty and degenerate.

Diagnosis. - The distinctive symptom of this disease is a very rapid beating of the heart.

Eitiology.- The cause of this hypertrophy of the heart muscle is not known, but it is probably due to some derangement in the nutrition of the muscle. The palpitations are increased by excitement or fright.

Treatment.-The disease is not usually recognized while the bird is alive. Treatment is therefore not possible.

Prognosis.- I hypertrophied heart may function for a long time. The violent beating may cause rupture of a blood vessel; sometimes several vessels are rupturerl at the same time.

Rupture of the Heart and Large Blood I'csscls.

Internal hemorrhage due to the rupture of the heart or large blood ressels often occurs in full blooded fowls.

Diagnosis-The bird becones weak and drowsy, passes into a comatose condition and dies with the characteristic appearance associated with bleeding to death.

Etiology.-In full blooded fowls any excitement or over-exertion which canses an increase in the rate of heart beat and an 
increased blood pressure may result in a rupture of the heart or one of the large vessels.

Treatment.- The accident can not he preclicterl and treatment is impossible.

Prognosis.- The birrl dies in a short time.

\section{DISLASES OF TIIE BLOOD.}

Varions cases of an alteration in the number of white corpuscles in the blood of fowls have becn described. Most of these descriptions are based on from one to three cases, and from the descriptions it appears that the investigators have found several different blood diseases. Most of these diseases when tested dicl not prove infections. They are impossible to distinguish except by microscopic examination and most of them are probably quite rare. Only one of these diseases seems to be of any conomic importance. This is Infectious Leukcmia, first described by Moore (Ann. Rep. Bur. An. Ind. I895-1896).

\section{Infectious Lcukcmia.}

This is a bacterial disease often mistaken for fowl cholera but caused by a different species of bacteria and the lesions produced are somewhat different.

Diagnosis.-The following symptomatology is quoted from Moore: "From the statement of the owners of the fowls in the different ontbreaks and from the appearance of those in which the disease was artificially produced, little can be positively recorded concerning the distinctive or characteristic symptoms. The only fowl examined ante-mortem from the natural outbreaks was first seen only a few hours before death, when it was unable to stand. If held in an upright position, the head hung down. There was a marked anemic condition of the mucosa of the head. It had an elevation of nearly 3 clegrees of temperaturc. An examination of the blood showed a marked diminution in the number of red corpuscles and an increase in the number of white ones. In the disease produced artificially by feeding cultures of the specific organism there was in most cases a marked drowsiness and general debility manifested from I to 4 days before death occurred. The period during which the prostration was complete varied from a few hours to two days. The mucous mcmbranes and skin about the head became pale. There was 
an elevation of from I to 4 degrees of temperature. The fever was of a contintous type."

"Although the course of the disease in the different fowls was usually constant, there were many variations. In a few individuals the time required for fatal results was from 2 to 3 weeks, but ordinarily death occurred in about $S$ days after feeding the virus, the rise in temperature being detected about the third day and external symptoms about the fifth or sixth, occasionally not until a few hours before death. 'The symptoms observed in the cases produced by fecding correspond with those described by the owners of affected flocks."

Dr. Noore found the only constant lesions to be in the blood and liver. The change in the blood as noted above was a decrease in the number of white cells. The change in the liver is described by Moore as follows:

"The liver was somewhat enlarged and dark colored, excepting in a few cases in which the disease was produced by intravenous injections. A close inspection showed the surface to be sprinkled with minute grayish areas. The microscopic examination showed the blood spaces to be distended. The hepatic cells were frequently changed, so that they stained very feebly, and not infrequently the cells were observed in which the liver cells appeared to be dead and the intervening spaces infiltrated with round cells. The changes in the hepatic tissue are presumably secondary to the engorgement of the organ with blood."

Dawson's diagnosis of the disease (An. Rep. Bur. An. Ind. I 898, p. 350) differs somewhat from the one given by Moore.

It is very difficult to distinguish this disease from fowl cholera except by identifying the bacteria which produce the diseases. Moore contrasts the characteristic lesions in the appended columns :

\section{Foul cholera}

I. Duration of the disease from a few hours to several days.

2. Elevation of temperature.

3. Diarrhea.

4. Intestines deeply reddened.

5. Intestinal contents liquid, muco-purulent, or blood stained.

6. Heart dotted with ecchymoses.

\section{Infectious leukacmia.}

1. Duration of the disease from a few hours to several days.

2. Elevation of temperature.

3. Diarrhea very rare.

4. Intestines pale.

5. Intestinal contents normal in consistency.

6. Heart usually pale and dotted with grayish points, due to cell infiltration. 


\section{Find cholere}

7. 1,ungs affected, hyperaemic or puenuonic.

S. Specific organisms appear in large numbers in the blood and organs.

9. Blood pale (cause not determined).

10. Condition of leucocytes not determined.

\section{Infectious leuka'mia}

7. Lungs normal , excepting in modified cases.

8. Specific organisms comparatively few in the blood and organs.

9. Blood pale, marked diminution in the number of red corpuscles.

10. Increase in the number of leucocytes.

Attention should be called to the fact that as yet there seems not to have been a careful study of the condition of the blood in fowl cholera. Dr. Salmon observed many changes in this fluid which may have been similar to or identical with those herein recorted.

On p. 2OI of Dr. Moore's paper he gives the method of differentiating the two bacteria. This is, of course, dependent on microscopic examination and cultural tests. A full description of Bactirium sunguinarium is given by Moore on pp. ISS-I9I of the paper cited above.

Etiology.- I'he disease is caused by a non-motile, rod-shaped bacterimm (Bactorimm sangumarimm.) 'This bacterium causes the disease when injected into the blood or when fed. In a few cases fowls are known to have contracted the disease by picking i1j the droppings of infected fowls.

Wore recent work* indicates that there is at least one sort of transmissible fowl lenkannia which is dependent upon a filterable virus, rather than upon a visible organism.

Moore says: "This disease of fowls has not been found in flocks where a good sanitary regime has been enforced. It is highly probable that it is a filth disease, being dependent upon unfavorable environments quite as much as the specific organism for the ability to run a rapidly fatal course and of spreading to the entire flock."

Treatment.-Prevention is the only known treatment. A maintenance of gencrally sanitary conditions and the avoidance of the introduction of diseased birds are effectual. If the dis-

*Ellerman, V., and Bang. O., Cent. f. Bakt., Orig., I908 xlvi, p. 595 ; Ztschr f. Hyg. u. inf .Krnkh., I909, 1xiii, p. 231.

Hirchfield, II., and Jacoby, M., Ztschr f. klin. Med. I909-Io, Ixix, p. 107. 
ease appears in the flock separate the diseased birds, disinfect the premises, and place the flock under sanitary conditions. The discase will probably disappear, as it is difficult experimentally to maintain an infection when the birds are kept under sanitary conditions.

Prognosis.-Diseased birds usually die in from a few hours to two weeks, but they may recover. 


\section{CHAP'TER TIV.}

\section{Diseases of the Nervous System. \\ Apoplery (Hemorrhage of the Brain).}

In this discase the bird usually drops dead or paralyzed with out showing any previous sign of illness. The only abnormality found on examination of the dead bird is clotted blood on the brain.

Etiology.-The cause of this disease is the rupture of a blood ressel in the brain and the pressure on the brain due to the blood which cscapes. The cause of this rupture may be an unhealthy condition (usually a fatty degeneration) of the walls of the brain bloorl ressels. The immediate cause of the rupture is increased blood pressure due to fright, over-exertion, or strain in laying (hens often die on the nest). This disease is more apt to attack rery fat birds and the degeneration of the vessels is supposed to be due to too rich food or to overfeeding.

Trcatmont.- Treatment of the affected birds is useless. Socalled "apoplexy cures," of which there are some on the market, should be left strictly alone by the poultryman. Only ecry rarely" can apoplexy be recognized till after the bird is dead, and then all the pills or potions ever invented for the purpose of swindling a gullible public will be of no avail. If scieral successive deaths from apoplexy occur, modify the ration, giving more green food and less meat and corn. See that the birds have plenty of range.

Prognosis.-The bird is usually found dead or dies in a little while.

\section{Heat Prostrations.}

In very warm weather heat prostrations may occur, cspecially among heary fowls. This is sometimes considered to be the same thing as apoplexy. The birds suddenly drop insensible or paralyzed. 
Etiology:--The cause is pressure on the brain, due to heat, but the blood ressels are not ruptured as in apoplexy.

Treatmont.-Mild cases may be treated by applying cold water to the head and leeping the bird in a cool, quiet place.

Prognosis.-Nild cases may recover. Others usually result fatally in a short time. As a preventative avoid overcrowding in hot weather. If the range is not provided with natural shade, supply artificially shaded places in which the birds may find protection from the hot sun during the middle of the day.

Congestion of the Brain (Vertigo, Cercbral Hypcramia).

A number of alonormal physiological conditions may lead to a congestion of blood in the brain. This is usually associated with a diseased condition of other organs, and hence often occurs as a complication with other diseases. It is sometimes due to injury of the head.

Diagnosis.-Pearson (Diseases of Poultry) gives the following diagnosis of this disease: "It is characterized by staggering, stupor, unusual movements such as walking backward or walking in a circle, unusual and irregular movements with the wings and feet and twisting the head backward or to the side. Sometimes the bird will fall on its side and make peculiar movements with its feet and wings as though attempting to run or fly."

Etiology.-The congestion of the brain is sometimes due to blows on the head or to fright or other intense excitement. Often it is associated witl acute indigestion or with the presence of parasitic intestinal worms.

Treatmont.-Apply cold water to the head. Administer a laxative ( 2 teaspoorsful of castor oil. or 30 grains of Epsom salts given in water or $1 \mathrm{~T} / 2$ grains of calomel). Keep the fowl in a copl. quict place. If this treatment is not efficient Salmon recommends I to 5 grains of bromide of potassium dissolved in I tallesponful of water 3 times a day. If intestinal worms are foumd in the droppings after the laxative, treat for the removal of these parasites (P. 79).

Prognosis.-'The bird may recover if the canse is removed.

$$
\text { Eipilipsy. }
$$

This somewhat rare disease is characterized hy occasional fits. between these the birds appear nomal. 
Diagnosis. - Pearson (Diseases of Puntury) describes the belavior of the hird during the fit as follows: "The fowl will make beating movements with its wings, its legs will draw up and it will fall down, sometines turn over on its back, or it may stand upright with its legs apart, head turned backward and month and eyes opening and closing spasmodically."

'l'his spasm passes away' after a time and leaves the bird in a normal condition.

I:tiology:-lt is often imponsible to discover any cause of the discase. It is said to be sometimes caused by tumors on the brain and sometimes by intestinal worms.

Troutmont.-The only cases that can be treated are those cansed ly the presence of intestinal worms. An affected bird shoukl be put up and given a laxative and if intestinal worms are passed treat the patient for the removal of these parasites (p. 79).

The birds may live some time with occasional fits and may recover. Cases caused by intestinal worms are definitely cured by remoring the parasites. 


\section{CIIPTER NI"}

DISHALS UF THE LUDESS. RHELMATSM AND LIMHERAECK. Gout.

Gout is a rather common clisease anong fowls. It is due to a failure of the kidneys to elininate the mates. 'The uric acid content of the blout is greatly increased and the urates are fleposited on the surface of the visceral organs. in the tissues of the nrinary apparatus and aromed the joints in the form of crystals of urate of soda. In fowls two forms of the disease cecur: the visceral. and the articular.

\section{liscoral Gout.}

In visceral gout the only simptoms shown by an affected bird are a hos in weight or "going light" and a slight yellowish tinge to the sin. cons and wattles. The bird has a good and often alnornal appetite. Death occurs sudelenly. An examination of the abclominal carity shows that all the organs and serons membranes are covered with a chalky or talcmm-like powder. Thi- powder has a mother-of-pearl luster and on microscopic examination is secu to be composed of small needle-dike crystals. These are crystats of mate of sorla. These crystals are also frumel in the minary organs. The weter and collecting tubules are often filled with a mass of these crytals. Drs. Hebrant and Antrine give the following test for the wrate of sorla.

Dissolice the crytals in nitric acid and evaporate in a watch slass. This gives a reel onion peel mass which tmrne purplish blte on the addition oi a solution of caustic potash.

\section{Articular Gout.}

In this form of the disease the erystals of wrate of sola are in nodules around the joints especially of the feet and toes. These nolules sometimes appear like strings of beart w the uncle sicle of the toes. They contain a white or creany thick

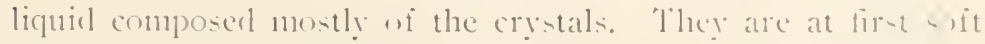
but later become very firm. The presence of the 1 s tule cause stiffuess and soreness of the joints and the birels bec mee in li-- 
poserl to stand or walk. Sometimes the nodules nlecrate, discharging a stringy pus and exposing the cavities of the joints to the air. 'The development of fistulas eause the death of the bones. The disease is slow in its derelopment and advanced stages are secu only in old birels. 'The birds lose weight and in adranced stages diarrhea sets in and death from exhaustion follows.

Early stages of this disease are often mistaken for rheuma. tism on account of the stiffness and soreness of the joints.

litiology.-The canse of this disease is a disturbance of the normal plysiology of excretion so that the uric acid which should be excreted by the kidneys is first retained in the blood and then deposited within the body as crystals of urate of soda. 'The disturlbance is probably due to a diet which is too rich in proteirls.

Treatinint.-In case of articular gout Salmon recommends rubling the affected joints with camphorated or carbolic ointment. In well developed cases it is more profitable to kill the bircls than to treat them. I isceral gout is not usually recognized while the bird is alive. Prevention is the only reliable treatment for either form of gout. Birds should be liept under santary conditions and given plenty of green food. When sevcral birds derclop the disease it is well to give the whole flock Epsom salts ( $1 / 4$ to $1 / 2$ teaspoonful per bird) and to reduce the amount of meat scrap and increase the quantity of green food.

Prognosis. - 'The disease, especially the articular form, is chronic and adranced cases are only found in old birds. Patly discased birds may live a long time. Mild cases may recover on corrected clict.

\section{Other Discused Conditions of the Kidneys.}

In the examination of dead hirds cases are often observed where the kidncys are diseased. They are often enlarged. Sometimes they contain clark points causer by the rupture of small bloorl vessels, and in other cases they may contain abscesscs. Micro-organisns have been obtained from some cases of diceased kidneys. Nothing is yet known of the canses of these specific discased conditions in poultry. Some of the cases of under-development, especially of pullets, are apparently due tr) enlargerl kidneys. In such cases the birds nswally lose their appetite, beenne emaciated and their feathers are roughened. Si) dependable diagnosis of discased kirlneys can be made on 
the living fowl. When several cases oceur care should be taken to see that the flock receives a balanced ration with plenty of green foorl, as diseased killneys may occur from too much protein in the foorl.

\section{Rhoumatism.}

A lameness or stiffness is usually considered rheumatism. Many such cases are due to tuberculosis of the joints (p. 6o), and others to articular gout (p. I2I), but there are muscular and joint inflammations caused by exposure which are properly considered rlicumatism. This discase is an inflammation of the connective tissues of the muscles and joints.

Eitiology.-It is caused by exposure to cold or clampness. 'The occurrence of sereral cases in the flock indicates something wrong in the housing conditions.

Treatmont.- The disease is prevented by keeping the fowls in dry, warm, well ventilated honses with well drained runs.

Prognosis.-Fowls protected from further exposure and given a good ration with plenty of green food ustrally recover.

\section{Limberneck.}

This is not properly a discase but a symptom which accompanies several diseased conditions. A fowl is said to have limberneck when partial or entire nervous control of the neck muscles is lost. The neck may hang limp so that the head falls on the gromel between the fect. Sometimes the bircl is able to raise the head from the grommel by making a great effort.

A bird is sonctimes said to have limberneck when the dorsal or lateral neck muscles are tense, the heal drawn convulsively backward. but this is more often called "wry-neck."

Both limberneck and wry-neck are due to nervous disorders which arice from several different causes. "Wry-neck" is usually associated with direct brain or nerve irritation and occurs in epileptic spasms, but also sometimes occurs in rhemmatism. Limberneck is usnally associated with colic, acute indigestion, intestinal parasites, or ptontaine poisoning.

No treatnent for limberneck as such can be advised. Eiffort should be made to ascertain and cure the diseased condition which i.s responsible for this symptom.

Cases due to rhemmatism, colic, indigestion, intestinal parasites, and some of those due to poisoning may recover, if the real canse can be ascertained and treated sonn enough. 


\section{CIAI'ER NII.}

\section{EATERNAL PARASITTS.}

$\checkmark$ igilant and continuous attention is necessary to keep fowls free from external parasites. At least 32 species of arachnids and insects are known to be parasitic on fowls. Some of these like the red mites visit their host only to take food and spend the rest of the time on the under sicle of the roosts, in cracks and crevices and varions other places of seclusion. Others like the lice normally stay on the birds, although occasionally some individuals crawl off, especially into the nest. Some of these parasites live upon the surface of the skin and upon the feathers. deriving their nourishment either by sucking the blood like the red mite, or by chewing the skin and feathers like the lice and some of the mites. Some of the mites, however, bore under the skin. catlsing skin discases known as scabies or psoric diseases. The most common of these discases are scabby or scaly leg and repluming scabies.

The comomic importance of these external parasites is rery great. Fowls infested with one or several of these species of parasites are not profitable. They make a smaller growth in the same time with the same food and their egg production is not eprual to similar birds not so infested. Not only are they constantly robbed of sone of their tissue and blood but their rest is disturbed. Sleep is as important to the normal physiolngy of a lirel as it is to that of a man.

Kecping a Poultry Plant Free from External Parasites.

It is not necessary for a poultryman to be able to distinguish the 32 species of parasites or to know their life histories in order to kecep his plant free from them. It is only necessary to know that some of them stay on the bircls and can only be exterminatud ly trating the bircls (usually with a powder) while others spend most of their time on the under sides of the roosts in cracks an l can bent be externinated by contact sprays containing cresul or lieruene. A single application is not efficient in 
either case but treatment must be repeated 2 or 3 times at intervals of a few days to destroy those that hatch after the treatment or are concealed beyond its reach. A routine procerlure by which a poultry plant can be kept free from parasites is very useful. The following method has proven rery successful at the Maine Experiment Station and is described in Circular 352 of that Station:

"'The routine method which the Station uses in handling its. stock with reference to the lice problem is as follows:

"All hatching and rearing of chickens is dome in incubators and brooders. The growing chickens are never allowerl to come into any contact whatever with old hens. 'Therefore. when the pullets are ready to go into the laying houses in the fall they are iree from lice. Sometime in the later summer, ustrally in August or early in September, the laying houses are given a thorough cleaning. They are first scraped, sconred and washed out with water thrown on the walls and floor with as much pressure as possible from a hose. They are then given two thorough sprayings, with an interval of several days interrening, with a solution of cresol such as is described in Cliap. 1I. Then the roosting boards, nests, floors and walls to a height of about 5 feet are thoroughly sprayed with the lice paint (kerosene oil and crude carbolic acid described on p. I35). Finally, any yearling. or older birds, whether male or female, which are to be kept over for the next year's work are given 2 or 3 successive dustings, at intervals of several days to a week between each application, with the lice powder described on p. I3o, before they are put into the cleaned houses.

"As a result of these methods the Station's poultry plant is at all times of the year practically free of lice."

This method keeps the flock free from lice and the mites which live upon the surface of the skin, but would not destroy those mites which penetrate the skin and cause scabies. These and other more rare parasites should be destroyed when present by special methods. The description of, and treatment for each class of external parasite is given below.

\section{A. LICE (MALIOPHAGA).}

Lice are probably the most widely distributed parasite of poultry. They are so common that flocks of fowls that have not been treated to remove lice for a long time are almost sure 
to have nue or more species present. At least $S$ species of hen lice have feen found and 5 of these are common. Bird lice are quite different from those which affect man and mammals.

'lo pepmlar nution that lice may be transmitted from poultry w other animals is quite erroneous. Theobalel (Parasitic Discases of Poultry) says: "So particular are bircl-lice that it is quite the exception to find one species upon two distinct kinds of birils. Fowl-lice will not even attack the duck nor duck-lice the fowl. Nearly every bird has its own particular Mallophasan parasite or parasites. They may possibly pass to some strange host for a short time, but they will not live and breed. Morover. . . . particular species attack restricted areas on the same host and are seldom found in other positions." Some of these lice are sliggish, nearly stationary, and confined to a restricted area of the body, while others are active and crawl over the entire body. The 8 known species are described in Thecobald's "Parasitic Diseases of Poultry," pp. 23-29.

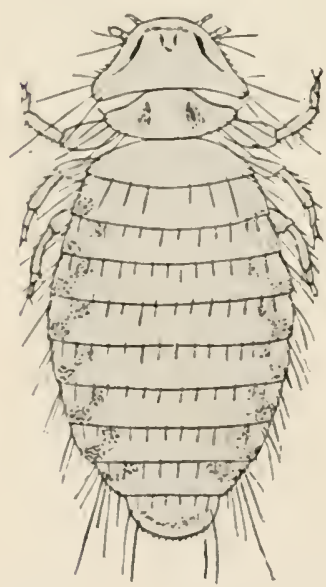

Fig. 24. The common

hen louse (Menopon fallid:min) Greatly cnlarged. (From Banks).

The most common and widely distributed hen louse found in this country is Menopon pallidum. This louse is shown in fig. 24.

Another species of this genus (Menofon biscriatum), which closely resembles M. pallidum, is also sometimes found. These are active lice living on all parts of the body. They often crawl on to the hands when handling or plucking birds. and may sometimes be found in the nests.

There are several other lice which sometimes infest poultry. Each of these species is confined to a special region of the host. Although capable of crawling about, the lice of these species for the most part remain nearly stationary, often with their heads buried in the skin and their bodies erect. Two species, Lipcurus z'ariabilis and Lipenrus hetcrographus, live among the barbs of the wing and tail feathers. Goniodes dissimilis is found under the wings and on the rump. The appearance of two of the species mentioned, viz., 
Lifcurus idriabilis and Goniodes dissimilis, is shown in figs. 25 and 26 respectively.

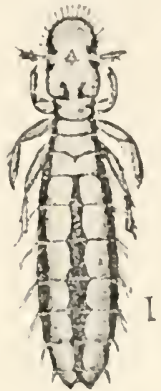

Fig. 25. Lipcurus i'ariabilis. A louse that infests poultry. Much enlarged. (From Banks after Denuy).

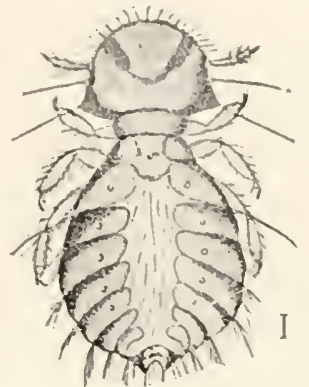

Fig. 25. Goniodes iissimilis, a louse that infests poultry. Nuch enlarged. (Fron Banks after Denny).

A short account of the mode of life; the conditions which faror their presence; their effect upon the birds; and the generalized life history of hen lice are given in Leaflet No. 57 of the English Board of Agriculture, pp. 3 and 4 . Firom this source the following is quoted:

"These Mallophaga have not a piercing mouth, their mouth is simply used for biting. They subsist upon the productions of the skin and fragments of feathers. They cause violent itching. and bite sharply, and must produce considerable pain when present in large numbers, as is too often the case. The feathers, especially the saddle hackle, generally show notched edges with lice infestation. Eight distinct species of lice attack fowls. The presence of these lice is generally ascribed to too uniform or insufficient mutrition, or else to lamp, dark, and dirty rums, especially those badly ventilated. Food, either when uniform or insufficient, has no effect upon their presence. Dark, damp places, however, when dirty, are sure to harbor all these pests. especially when badly ventilated. It is also saicl that breed affects their presence, but observation tends to show that all breeds are more or less subjected to infestation. In every case they set up severe irritation and inflammation of the skin, which often leads to stunted growth, and even death. Lice and nther parasites flourish on unhealthy birds." 


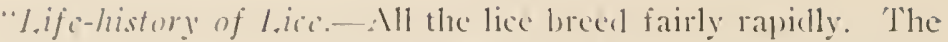
(xys or nits are laid mon the down feathers, ats a rule; they are niten leatutifully seulpturerl objects. oval in form. In about 6 t) 10 days they hatch into small, pale, active lice, which at once commence to irritate the bircls. 'The arbults are occasionally finul in the nests. Some species are foumd copulating in the nests, whers always on the birls. 'They live a considerable time. Jenopon pallidum (Fig. 24) has been kept alive for monthi mpon iresh feathers, the quill cpiclermis being especially catcu. liefore reaching the full-grown state as many as or or 1 2 moults apparently take place, there being little lifference in (ach stage, execpt the gradual larkening of the markings."

the eggs or nits of hen lice are shown in fig. 27.

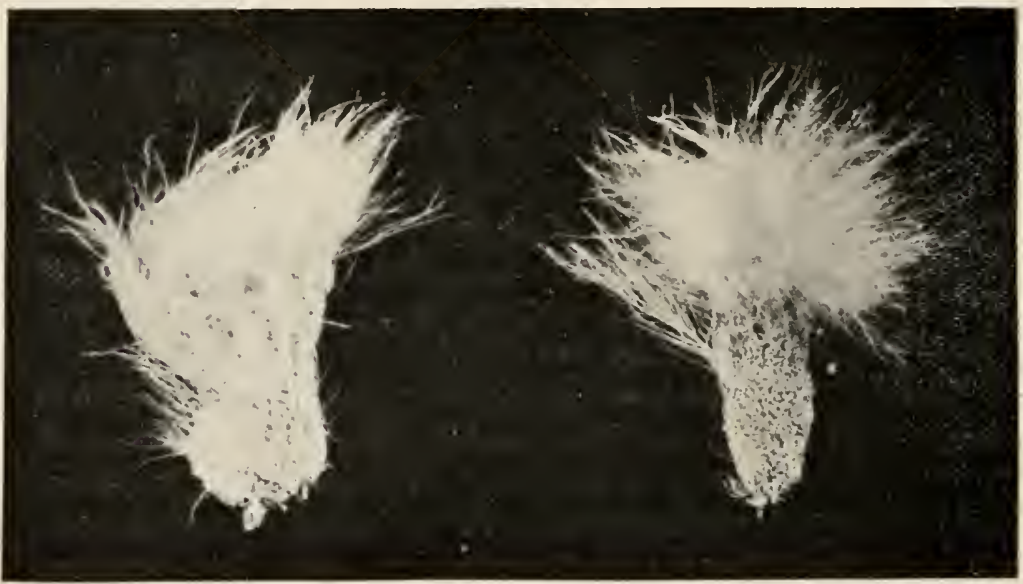

Fig. 27. Feathers thowing eggs or "nits" of the common hen louse. Enlarged (Original).

Mcthods of Introduction and Infestation.-It is generally agreed that lice and other parasites flomrish best in insanitary surroundings. There must, however, be a source of infestation. I ice are bronght to a new place by introducing infested hirels. They spread from bircl to bircl (a) directly during copulation (an infested cock often infests the whole flock), or (b) when two hens occupy a nest together, or (c) from mother to chick. 'They' also pass indirectly from bird to bird by crawling off one hirel first on to the nesting material and later on to another bird which uses the same nest. Doctor Sharp has also 


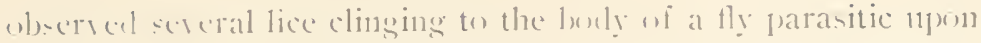
clickens. Lice are $\rightarrow$ much more common than the parasitic Hy that it in probable that this insect is of little real importance in the distrilution of the lice.

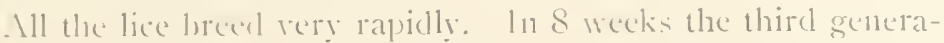
tion is nuature and in this generation the estimated number of the wfirpring wi a ringle pair is 125.000 imelividuals. It secms important to cralicate an infestation it ponible as soon as dis-

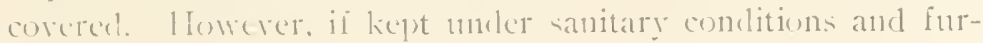
nished with plenty of attractive dust, vigorous birds will hold extermal parasites in check. With sone attention to sick birels. setting liens and romug chick- the para-ites will give little trotilsle w a plant comelucterl with clue regarel to the principles of luegic ne and -anitition (cf. Chajs. 11$)$.

Dianmosis.-." It slunild he remenulereel at all times that the coternal animal para-ites are the most (ommon and frequent cance of tronlile in the yndtry-yare and pigeon-cote. If the birls are 1ust thriving and conducting themselves satisfactorily, look fur these gest - take neastures to repress them. and in most cases the rewelti will be surprising and gratifying. When anything is the matter with a horse the maxim is eramine his feet. and when anything is fontul wrong with poultry wr other domesticated bird . the maxim should be look for lice." (Salmon.)

Alult hem may harlor (fuite a mumler of thene parasites withnut -huming any -ymptom which inclicate their presence. If they are unthrifty anrl broudy hens leare their nests they should le exannere for lice. 'Tlhe biting and ligging of the claws of the lice may canne sores and the nerrous irritation and lose of sleep maty catu-e wencral debility and bowel trotidele. Little chickchl are rery -triceptible and often dic. I,ice are frequently Inumd in larpe numbers on bircls sufiering from roup. gapes, ete. In sume cases their presence has remblererl the hirels more susceptilsle to thler (lineare. While in others it is probable that the hirel- lack sufficient energy to dust themselves.

The sure te-t for the presence of lice is, of course. finding the lice. I'art the fathers uncler the wing. on the back and around the vent and examine the exposed skin. Examine the hearl and neck feathers and lowk between the large ieathers of the wing.

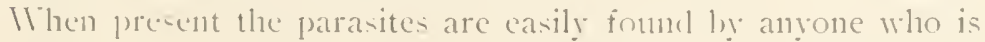
familiar witl them. It seems increalible that serions infestations can esape the cye of any junltrynan. 
Treatmint.-Sinitary surromulings and liberal range help the birls in their attempts to keep themselves free from lice. The dust lath is very efficiont in lonlling the pests in check. It is dembtful, huwerer, whether the dist boxes which used to be almost minersally liept in the poultry house are of any real value. It is a noticeable fact that dust hoxes are much less used now than formerly. 'Ihis Station has not made use of them for a n11mber of years. As commonly made these boxes are too small, and too shallow, and are not filled with the proper kind of material. Hens will use them, in most cases, only as a last resort if at all.

When possible, birds should be given access to dry, sandy ground, and they will provide their own dist bath. Some attthors advise adding insect powder to the earth in dust boxes for bad infestations. It is doulbtful whether under the best of circumstances this does anything but waste the insect powder. It is better to apply the powder directly to the bird and furnish clean earth for the dist bath.

When hens are used for incubating and brooding it is necessary to give some individual treatment to brooding hens and young chicks. It is also necessary to treat sick hens which are not able to nse the dust bath. While it is theoretically possible to exterminate the pests and keep the flock free from them by avoiding the introduction of infected birds, this ideal condition prevails in very few poultry plants. In almost all flocks there are enough lice present to cause trouble if conditions favor their development. Robinson gives a very good method for preventing tronblesone ontlureaks in the following words:

"Treat with insect powder every sick fowl, every fowl that has heen cooped for some days where it could not dust itself, cvery sitting hen when set, and at least twice again during the periorl of incubation, the last time just before the eggs are due to pip; treat the young chicks and hen when a brood is taken from the nest, and at intervals of a week until 3 weeks old."

\section{How to Make an Effectice and Very Cheap Lice Powder.}

When the treatment of individual birds for lice becomes necessary some kind of powder dusted into the feathers thoroughly, scems to le, on the whole, the most effective and advisable remedy. 'The powder used must be of such nature, however, that it will be effectice. There are so-called "lice powders" on 
the market which are no more effective than an equal quantity of any inert powilerel substance wonly be. It is not only a waste of money but of time as well to use such powders. At the Maine Station no lice powder has been found that is so satisfactory as that originally invented by $1 \mathrm{r}$. R. C. Lawry. formerly of the poultry department of Corncll University. The follnwing matter regarding this powrler (which can be made at a cost of 5 cents per pound) is quoted from a circular issued by the Maine Station:

"In using any kind of lice powder on poultry, whether the one described in this circular or some other, it should always be remembered that a single application of powder is not sufficient. When there are lice present on a bird there are always unhatched eggs of lice ("nits") present too. The proper procedure is to follow up a first application of powder with a second at an interval of + days to a week. If the birds are badly infested at the beginning it may be necessary to make still a third application.

"The lice poidder which the Station uses is made at a cost of only' a foi' conts a pound in the following way:

"Take 3 parts of gasoline,

"I part of crude carbolic acid:

"To get the proper results only the $00-95 \mathrm{per}$ cent. carbolic acid should be used for making lice poider. Weaker acicls are ineffective."

"Owing to the difficulty in getting the strong crude carbolic acid locally in this State at reasonable prices, the Station has experimented to see whether some other more readily obtainable substance could not be substituted for it. It has been found that cresol gives as good results as the highest grade crucle carbolic."

"The directions for making the powder are now, therefore, modified as follows:

"Take ? parts of gasolinc, and

I part of crude carbolic acid. $00-95 \mathrm{per}$ cent. strength, or, if the $90^{-9} 9 \mathrm{fer}$ cont. strength crude carbolic acid cannot be obtaincd take

$$
\begin{aligned}
& 3 \text { parts of gasolinc and } \\
& \text { I part of cresol." }
\end{aligned}
$$

"Mix these together and add gradually with stirring. enough plaster of paris to take up all the moisture. As a general rule if will take alout + quarts of plaster of paris to I quart of 
the linfuicl. The exact ammunt, lowerer, must be determined hy the condition of the powrer in eated case. 'The liquid and dry plister slomlel be thoroughly mixed and stirred so that the liquicl will be miformly distributed through the mass of plaster. When enemsh planter has been adcled the resulting mix-

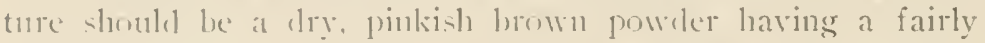
strung carbolic orlor and a rather less pronounces sasoline oclor."

"1)( net use more plaster in mixing than is necessary to blot up the liepuicl. This poweler is to le worked into the feathers of the birk affected with vermin. The bulk of the application should be in the lluff around the rent and on the ventral sicle of the boly and in the fluft muler the wings. Its efficiency, which is wreater than that of any other lice powrler known to the writer, can be very easily (lemonstrated by anyone to his own satisfaction. 'lake a birl that is covered with lice and apply the powrler in the mamuer just elescribed. After a lapse of about a minute. shake the bircl. loosening its feathers with the fingers at the sime time, over a clean piece of paper. Dead and dying lice will rlop on the paper in great numbers. Anyone who will try this experiment will have no further doubt of the wonteriul efficiency and value of this powder."

Next to the I awry power probably pure prethrum or Persian insect poweler is as cheap and effective as anything to be l.at.

I time-honored and effective treatment for lice. especially for young chicks. is greasing. The grease most often used is lard or sometimes lard and sulphur. 'The latter should not he nised for yomng chicks. 'lhe lard is applied with the funger to the hearl, neck, uncler the wings and around the vent. Creasing is a somewhat teclious but very effective treatment for lice. especially on young chicks, since lice usually attack them on the head and neck.

Frof. II. R. Graham, in conversation with one of the writers, has strongly recommenterl the use of blue ointment (Ungucu-. tum hydrargyri, U. S. P.) to rid birds of lice in cases where individual treatuncut was demanderl.

\section{MITES-ICARINA.}

Fighteen species of mites are parasitic upon fowls. Only 4 of these are sufficiently injurious and widely distributed to be 
of great econemic importance. Occasionally one or another of the other species becomes sufficiently abundant to be of local impurtance. The mites are small S-legged animals related to the spiders. Some of the mites parasitic on the fowl visit their host only to feerl, as the common red mite; others remain on the surface of the skin or on the feathers, as in the case of repluming seabies. Others live under the skin, cansing deep-seated skin diseases like scaly leg; still others find their way into the internal regions of the budy. living either on mucous membranes like the air sac mite (p. I Io) or upon the connective tissue like the enmective tissue mite.
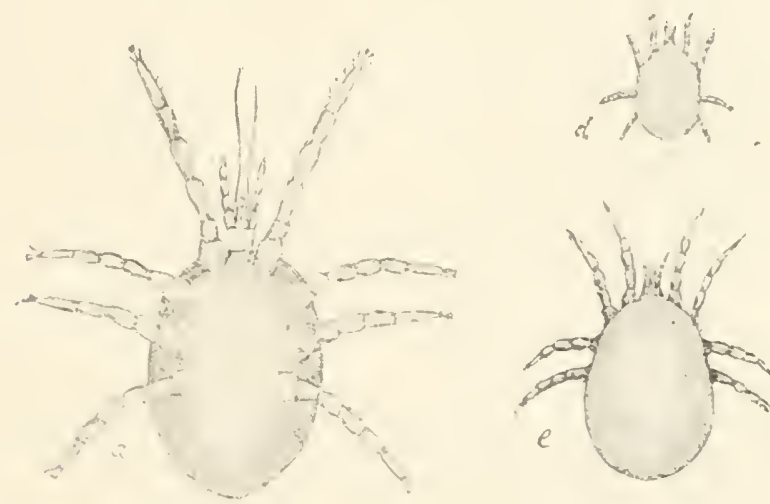

Fig. 28. The common "red mite" of poultry, Dermanyssus gallinat, a, arlult. $\mathrm{d}$ and e, young. (After Osborn).

The most common and most injurious mite parasitic on fowls is the common fowl mite or red mite. Dermanyssus gallina. 'These mites are present in almost every poultry house that is not kept very dean. When they are present in large numbers they are a serions pest. 'This mite is a little more than $\mathrm{T} / 2$ millimeter long. The female is a little larger than the male. When empty they are gray with dark spots. but ustally they appear some sharke from yellow to dark red according to the amount of fowl's blowel they contain. They risit the fowls only to feed and spend the rest of the time on the under sides of the roosts, in cracks and crevices, under collections of droppings or other fith and in the nesting material, especially if such material is dirty straw. The mites breet in these places. They reprodnce very rapidly, especially in spring and stmmer. The eggs are laid in con- 
ceileal places, usmally in crates containing filth or in dirty nesting material. 'The young mites are white and have only 6 legs. 'lleir lirst food is probably filth or decayed wood. 'They moult screral times and their cast skins are often seen as a white powiter on the perches. Ifter the first moult the larve have s legrs. 'The mite's are able to live and reproduce for months at kast without animal food, but when they are associated with forls the older larve and adults depend upon the bloorl of the fowls for food. They usually attack the bircls at night but sonetimes are found feeding on laying or brooling hens during the day. They pieree the skin with their needle-like jaws and suck the blood. The irritation due to the biting of a number of these creatures disturbs the rest of the bircl and the loss of blowd may be considerable. The mites thrive best in dark, (lamp, dirty houses and may be found in such houses for months after all fuwls have been removed. 'They will bite man or other mammals, causing severe irritation, but do not remain on strange hosts for any length of time. Fowls should not be allowed to roost in sheds with other animals, as the sheds may become infested with the mites which will disturb the other animals as well as the fowls.

Diagnosis.- If the birds are not doing well, especially if they appear cmaciated and dejected, they should be examined at night for mites. In the day time the ends and under sides of the roosts and the cracks in them should be examined. Numbers of the mites are often found by prying up a loose cleat or splitting off a wide loose sliver. They may often be found in old straw nests.

Treatment.-Clean, dry, well ventilated houses which get plenty of sunlight are seldom badly infested. The first step in cradicating or controlling the pest is thoroughly to clean the louses. Kemove the droppings and all the old nesting material. Clean and when possible scrub or wash with a stream from the hose all the perches, nests, floors and walls. Spray or paint the perches, nests, walls and floors with a 5 per cent solution of cresol (sce Cliap. II for directions for making this). Prof. $\mathrm{H}$. C. l'ierce has tested various remedies for mites and finds none so effective as this. Use plenty of solution and make the spraying thorough. Every crack and crevice should be flooded. 
Another spray successfully used is: 3 parts kerosene and I part crucle carbolic acid. Still a thircl. kerosene emulsion is recommended by the Lnited States Department of Agriculture. Their methor of making this spray as given in Circular No. 92 is as follows: "'l'o make this, shave $1 / 2$ pound of hard soap into I gallon of soft water and boil the mixtme until the soap is dissolvesl. Then rennove it to a safe distance from the fire and stir into it at once, while still hot, 2 gallons of kerosene or coal oil. 'The result is a thick, creamy enn11sion. Dilute this stock mixture with 10 parts of soft water, and apply as a spray or with a brush, being careful to work it into all cracks, crevices, and juints of the builkling."

Witl any of these sprays it is necessary to make two or more applications at intervals of a few days to destroy the mites which hatch after the first application. The liquid may be put on with a hand spray pump or witl a brusl. Cleanliness, fresh air and sunlight are cheap and effective preventatives.

$$
\text { Scaly Leg. }
$$

A minute mite. Kmomidocoptes (Dermatoryctes) (Sarcoptcs) miutans, is the cause of a contagious clisease affecting the legs of fowls, turkeys, pheasants, partridges and cage birds. According to some authorities it sometimes affects the comb and bcak also. 'The nites excavate places nuder the skin where they live and breed. The most thorough study yet made of this parasite and its effect on lirds is that of Haichk.*

Diagnosis.-This very common disease is easily recognized by the enlarged ronglened appearance it gives the foot and shank. This appearance is shown in fig. 29. with a normal leg for comparison.

The disease is present in most flocks unless especial care has been taken to exchude it. It is slightly contagious, but usually only a few bircls in a nock appear to be infected. The scales on the foot ard leg of an affected bird are raised by a crusty substance xposited beneath thenl. The lesions nswally appear first near the joints between the toes and font. The parts affected first appear to be enlarged and then the scales are raised, giving the romghened appearance shown in B fig. 29. In carly

*IIaiduk, T. I)ie Fussränder des Geflügels. Inaug. Diss. Giessen, Ic09. PP. I-58, Taf. I-V'I. 

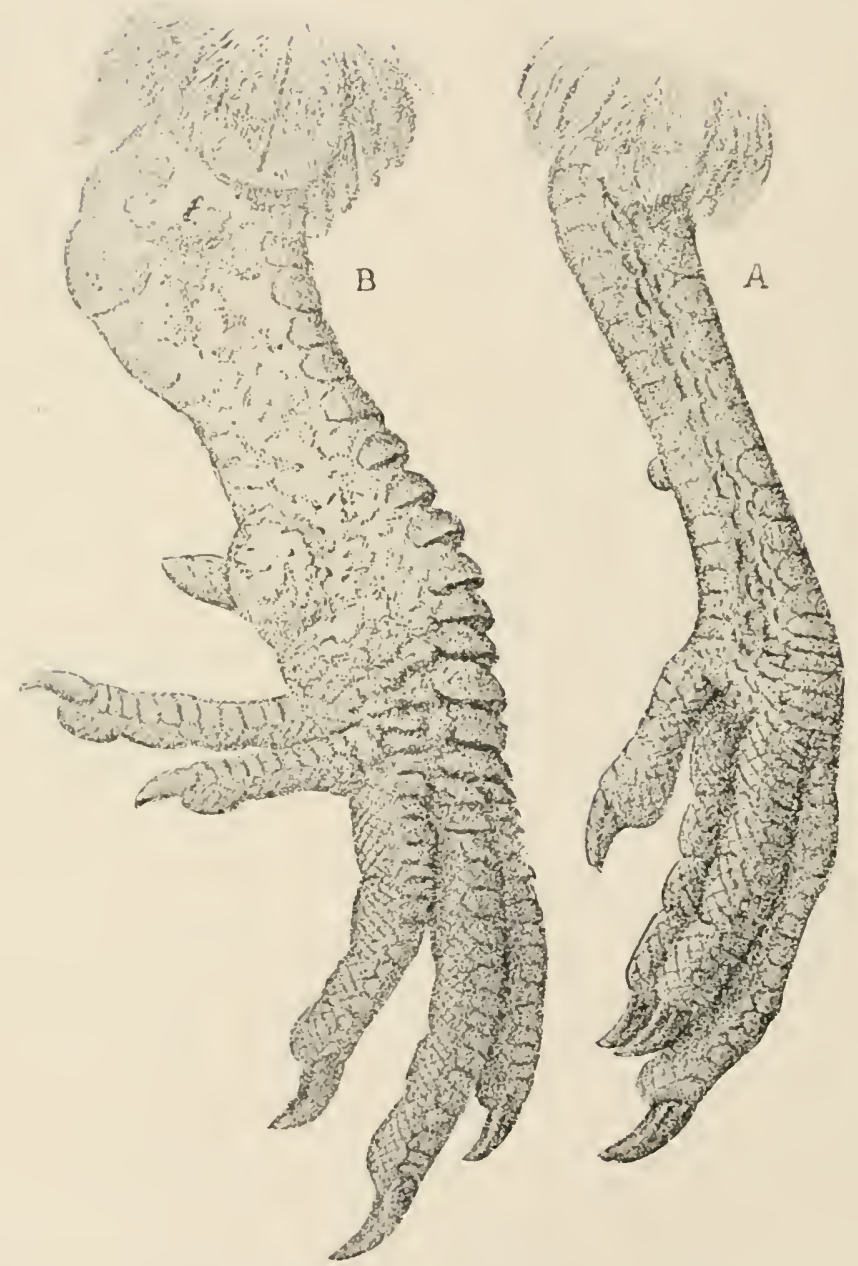

Fig. 29. A. Nommal leg of hen. B. I.eg of hen affected with scaly leg. (Aiter Megnin). 


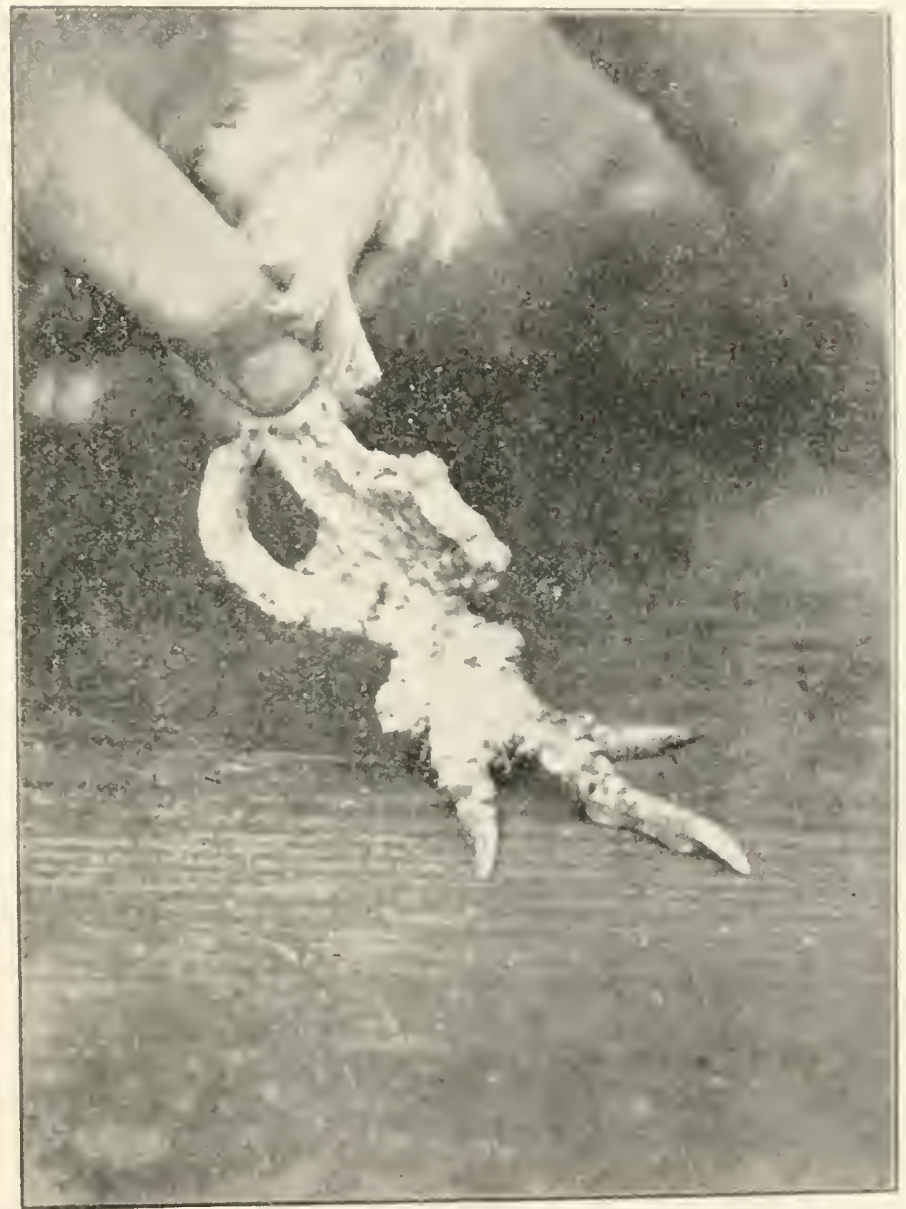

Fig. 30. Photograph of the leg of a hen affected with scaly leg. (After Ilaiduk). 
stages the discase does not appear to disturb the general health of the fonl. As it progresses the birds become lame and sometimes the foot becomes so badly diseaser that joints or even whole toes drop off. The photograph of a barlly affected leg is shomn in fie. 30. The two legs are nstrally aftected equally.

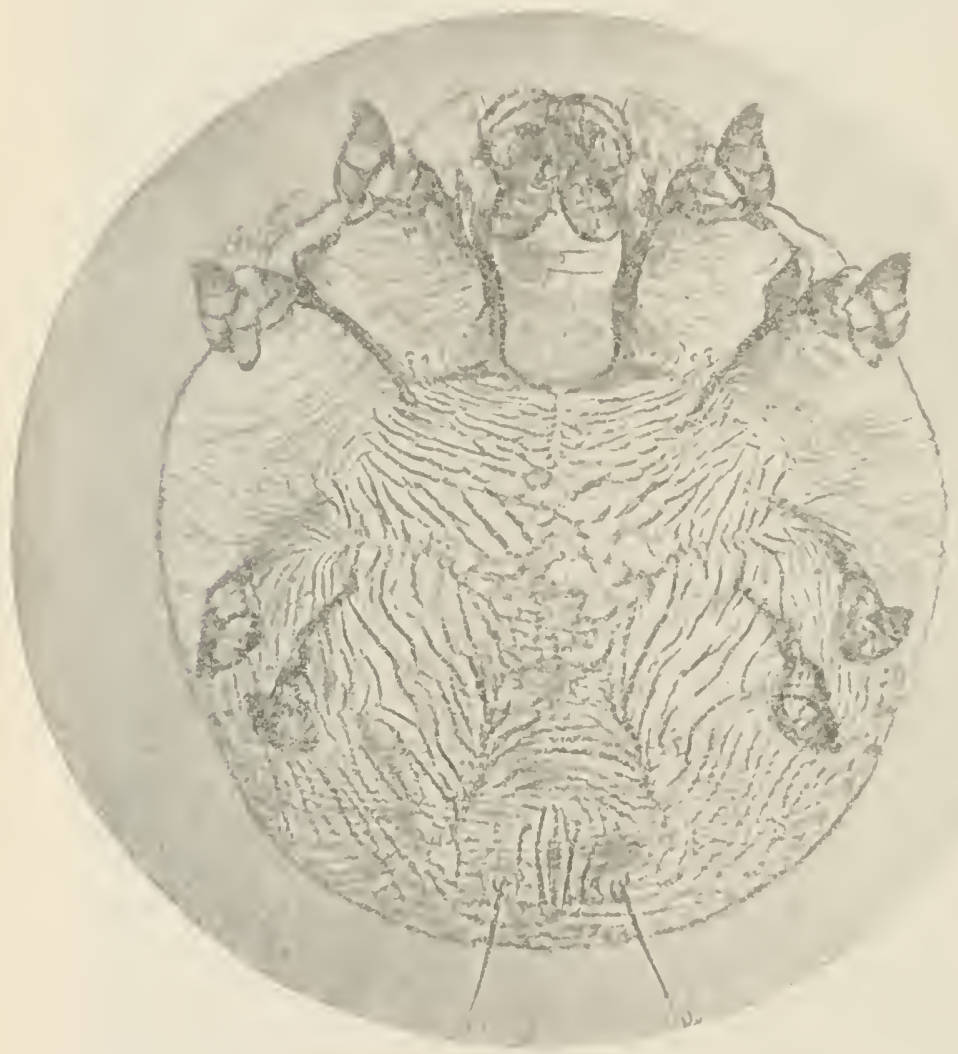

Fig. 3r. Plotograph of the adnit female of the mite Knemidocoptes (Dermatoryctes) mutans. (After Haiduk).

litiology.- 'The disease is caused by the minute parasitic mite Knemidocoptes mutans (figs. 3 I and 32). 


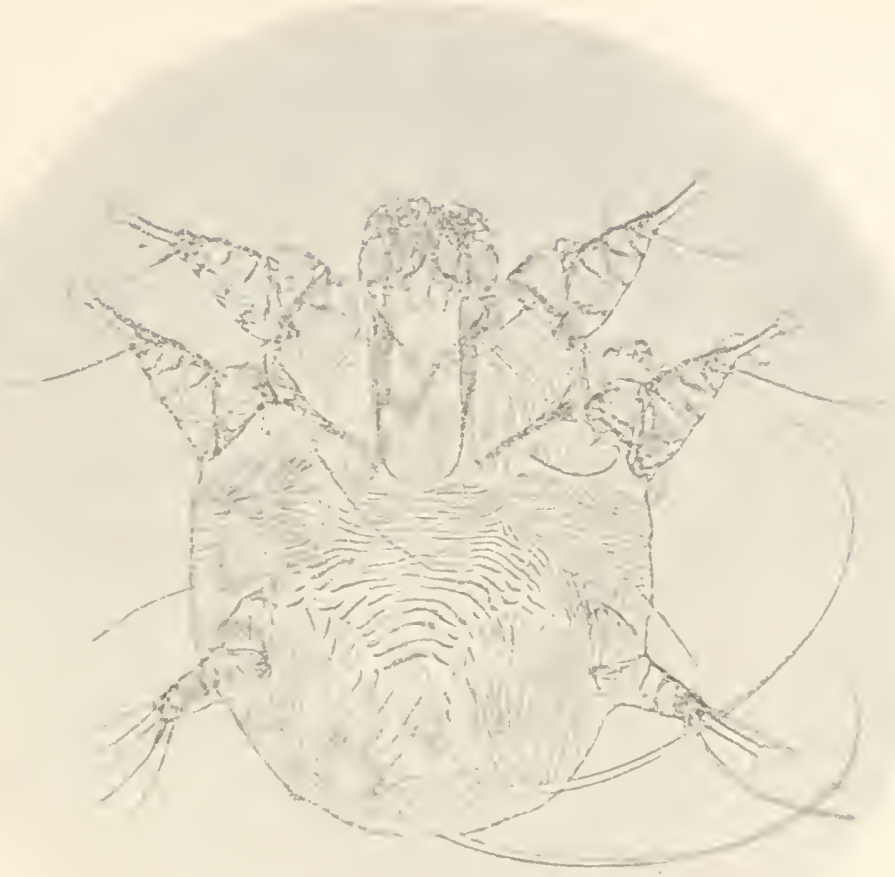

Fig. 32. Photograph of the six-legged larva of Knemidocoptes (Dimutorgites) mutans. (.Ifter Haiduk).

The mites bore under the scales of the foot and leg and burrow leeper and deeper into the tissue. 'They set up an irritation which leads to multiplication of cells and the exulation of serum. This accumulation forms crusty deposits beneath the scales. These crusts contain many depressions in which are imbedded fonle mites containing eggs. The larve and the males are usually found bencath the crusts. The relations just described are shown in fig. 33. Which is a picture of a section of the skin of a "scaly" leg. 


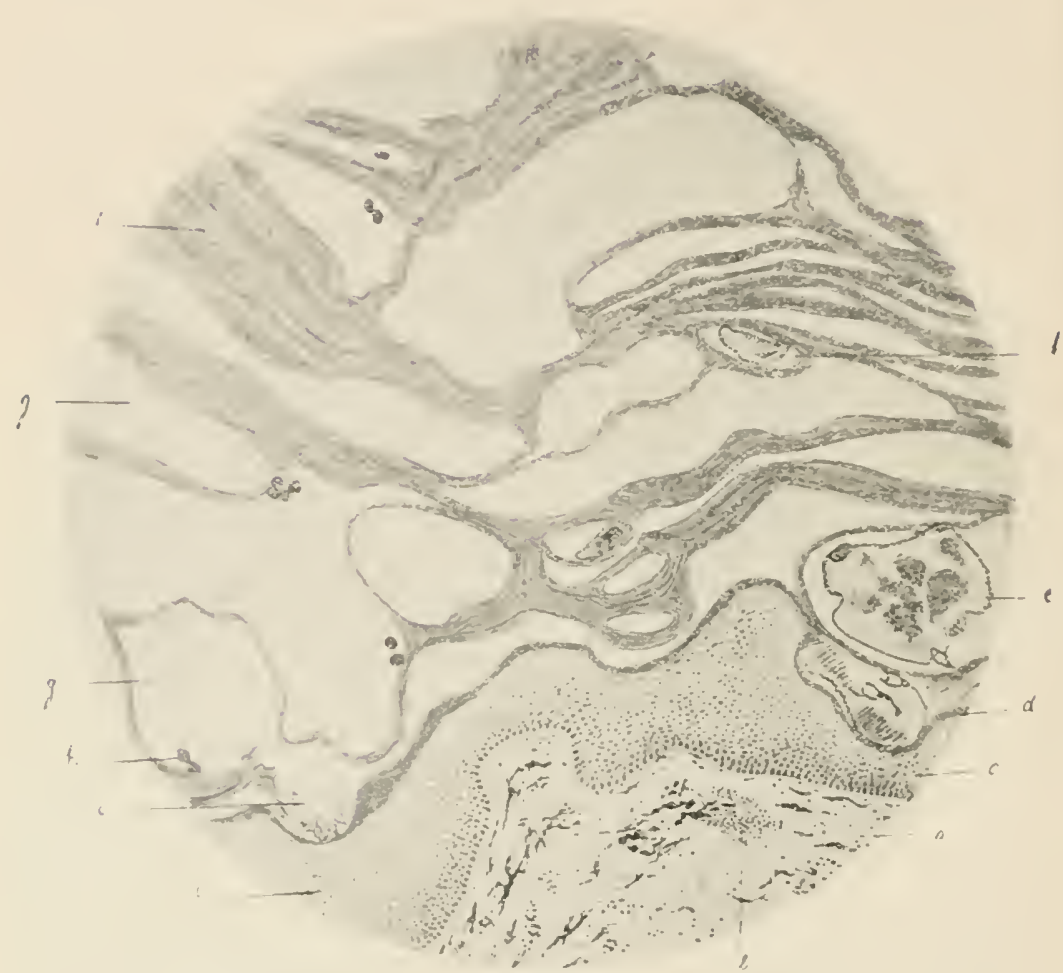

Fig. 33. Section of the skin of the leg of a fowl affected with scaly leg.
a. Papilla with pigment cells.
1). Lymphatic tissue in the papilla.
c. Epidermis: stratum profundum.
d. Epidermis: stratum corneum.
c. Section through a mite.
é. Section throngh a mite showing head and 2 pairs of legs.
f. Young mite.
g. Cavity excavated by mites.
h. Excrement of mite.
i. Horny layer between the mite excavations.
(From Haiduk, after Olt). 
As the discase progresses the mites which are becoming onnstantly nore numerons penetrate rery deep into the tissues. cansing lanneness and sometimes the loss of some of the toes.

The infection from bird to birel probalily takes place on the roosts or from mother to chick. Robinson believes that the birds mest likely to be infected are those with a deficient supply of oil in the skin. The conclitions which favor its spread in a flock are dry, harren rins, especially on alkaline soils or in yards filled with ashes or cinders. Foul roosting places also favor the spread of the discasc. The discase is easily cured and it is worth the tromble of any poultryman to cure all the affecterl bircls ancl to examine any birds purchased that infected ones may be treated hefore they are introdiced into the flock.

Treatment.- Individual treatment is necessary to cure the disease. This treatment consists in the application of some penetrating oil to the discased parts. I large number of oils and ointments have been used siccessfully. If the case is not far atvancerl and if there is no especial hurry abont bringing about the cure the application of the oils or ointments at intervals of 2 or 3 days will soon do the work. If the birds munst be cured quickly for show or sale prirposes the cure is hastened by remoring the scales and crust- before applying the medicine. This may be done by brushing with a stiff toothbrush before each treatment. Or the ieet may be soaked for a few moments in warm soapy water and then brished. When the lisease is far adrancel it is best $t$ o begin the treatment by the removal of the scales.

Haikhts's experinents show that one of the very best cures for scaly leg is oil of caraciay. This is best applicd in an ointment made of I part of oil of cararay to 5 parts of white a'aseline. Oil of caraway is very penctrating and is not nearly as irritating as some of the treatments more usually advised. This ointment should be rubbed into the les and foot every few clays until signs of the discase disappear.

Hill recommends daily application of an ointment made of equal parts of vascline and zinc ointment, or in serere cases of one marle of 1 omuce of sulphine, I/2 ounce of oxide of zinc, I dram $n i$ oil of tar and 2 ommes of whale oil mixed together.

'There are two common remedies used successfully by poultrymen. These are irritating and should be nsed with some caution. They have the advantage of heing quickly applied. 'The best of these is probaldy a mixtme of a part of coal nil or kero- 
sene and 2 parts of raw linsecel oil. If a quick cure is imperative a half-ant-half mixture may be nsed. Robinson in Farm Poultry, May, 1907. recommends a quick and easy method of apjolying this. It is to take a tall cuart measure of the liquicl to the hen house at night and dip both legs of each infected bird into the measure of (ill, holding them there for a moment and then allowing them to drip for a moment more and then replacing the hen on the roost. With any treatment which involves the use of kerosene care nust be taken not to wet the feathers of the leg. as this causes irritation and sometimes burns the skin much as the human skin is burned when it is rubbed with kerosene and covered with flannel.

$\Lambda$ second method of applying kerosene is to put a teaspoonful of the oil in a quart measure of water and treat the birds by the method given above The same care should be taken not to wet the feathers.

The adrantage of these treatments is their easy and rapid application to a number of birds.

\section{Dcpluming Scabics.}

'The mite Sarcoptes laits var. gallina (fig. 34 ) is the cause

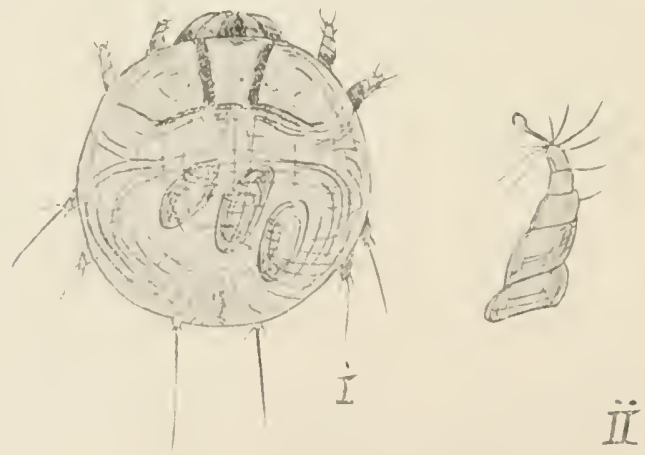

Fig. 34. Figg containing female Sarcoptes

Jacis var. gallinac. (After Theobald).

of a kind of scabics in fowls which canses the feathers to break off at the surface of the slin.

Symptoms.-This disease usually appears in spring and summer and is characterized by the dropping off of patches of 
feathers on clifferent parts of the body. It usually begins at the rump and spreals to the hearl and neck, back, thighs and breast. The large wing and tail feathers are not usually lost. The exposed slin is normal in appearance. Around the stumps of the lost feathers and at the encl of the quills of feathers near the bare spots are masies of epidernal scales. On microscopic examination these scales are foumd to be composed of mumerous mites and their debris. The irritation of the mites of ten causes the biris to pull their own feathers. Birds affected of ten pull cach uthers feathers. Some of the so-called feather cating is due to the presence of this parasite. but fowls sometimes pull each other' feathers when the parasite is not present. Salmon says this disease does not affect the general health of the bird anrl cloes not appear to (listurl) gain in flesh or egg production, but Theobald says that the discase checks egg laying in hens and affected cocks become emaciated and sometimes die.

Etiology.-The nite Sarcoptes lar is which causes this disease is smaller than the one which canses scaly leg. They live at the base of the feathers in the epidermal debris referred to above. A flock becomes infected by the introduction of one or more birds carring the mites. The nintes are spread from bird to bird by the male in copulation. The distribution is often very rapid so that the whole flock is soon affected.

Treatment.-'The disease should be prevented by taking care not to introduce infested birds. If it appears all affected birds should at once be isolated. 'The mites yield easily to treatment. The infesterl areas may be rubbed with some of the less irritating ointments recommended for scaly legs (see p. I4I).

The following list gives some ointments in the order of their desirability for use on the body.

Oil of caraway ointment ( $\mathrm{I}$ to $\mathbf{5}$ ).

Palsam of Peru.

Creolin treatment ( $\mathrm{I}$ to IO).

Helmerich's ointment.

Salmon gives a modification of the latter ointment which he considers an imporement for use in depluning scabies.

Flowers of sulphur. I dran.

Carbonate of potash, 20 grains.

I arel of raseline, $\mathrm{I} / 2$ ounce.

Scabies may also be cured by liquirl applications. The two following preparations are recommended by Salmon: A solu- 


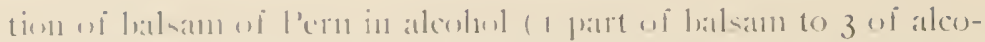

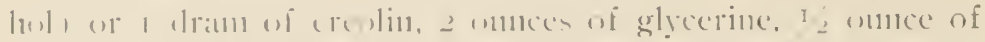

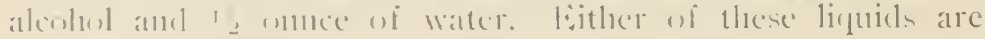

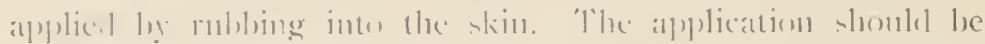

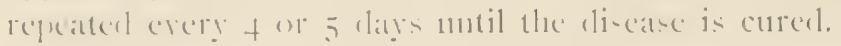

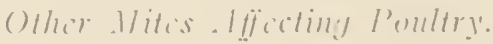

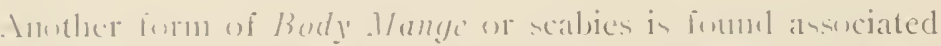
"ith the mites Epidermoples bilubelus amel lipidermoptes bifurcatus, but it lias not been certainly alemomstrated that they are

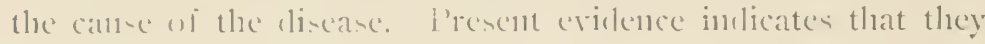
are.

'The discase closely resembles farus (p. i47) but usually does mot atiect the heacl. 'llie regions commonly attackel are the neck, luean, the wings and the bofly muler the wings. It semetime affects the entire luxly. inclucling the heat. The skin be-

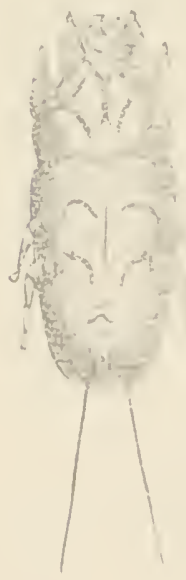
(n)mes irritated and sluws an accummlation of scales or crusti especially at the base of the featiners.

The mites live on the skin at the hase of the feathers. Since the mites are sonnetines found (n) birle which show wo signs of scabics and since the discane so closely resembles fartus, which is known (o) be callued ly a fungus, it is sometimes sup)po:(ul that this mange is also the tu a fungus and that the mites are inoffensive.

Five suecies of mites have been recorder which live mon the feathers of fowls. 'These are fairly abmuklant but rlo ne hawn.

Two mites live within the bonly of fowls. One Iiig. 35. Symp-of these, the air sac mite. is tescribed elsewhere tcituptes iss-(1). IIO). "The other the comnective tissue mite, ticola. Con-Simplectoptes cysticola, js found in the connective lissuenective tissue of the fowls. They produce local mitc. ( Wferirritations giving rise to tubereles lunt apparently 'Tlicobald). 1) 100 affect the licalth of the bird.

'The larvae of the so-caller] "larvest-buge" (which is not a bug at all) Telranlchus (Thrombidium) (I-cptus) autumnalis sometimes attacks ponltry. 'Jhe appearance of this mite is shown in fig. 36. 
This small brick red mite, rarely visible

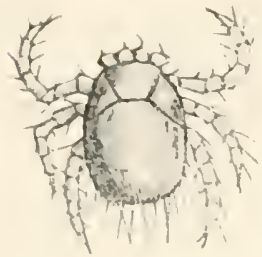
to the naked eye. is bred upon berry and currant bushes, vegetables and grain, but when opportmnity offers it bites almost any animal, often attacking man. It sometimes causes considerable mortality among late hatched chickens which frequent its breeciing places. The parasites fasten Fig. 36. "Harvest themselves so firmly by their claws and (I.eptus) autumn-palpi that they can only be detached by alis, larval form. force. They produce intense irritation (After Murray). Which often learls to epileptiform symptoms and death follows in a few days.

Theobald suggests dusting flowers of sulphur among the feathers when the parasites are present. Probably the Lawry lice powder (p. I3o) would be more effective. When these parasites are abunclant chickens should be kept away from the places where the mites breed.

\section{Other Eirternal Parasites.}

The dor'e cot bug or "bed-bug" of poultrymen, foumd in pigeon lofts, sometimes invacles neighboring hen roosts. It probably sometimes attacks fowls. It resembles closely the bed bug fombl in dwetling houses and like this pest is hard to exterminate as it can live almost indefinitely on clearl organic matter. This tick hicles in cracks during the day and attacks its host only at night. Persistent repetition of the sprays recommenderl for hen roosts infected with red mites (p. 134) will destroy these parasites.

Leaflet No. 57 of the English Board of Agriculture gives the following brief account of the hen flea, Pule.r gallinas for arium):

"The fleas, which are true insects, belong to the order of flies (Diptera). 'They feed upon the blood. One species only lives upon the fowl, namely the bird flea (P'ule gallinat or arium) which attacks also most other bircls. The hen fleat, ats it is generally called, is abundant in clirty fow rums, and especially in the nests where straw is used. The adult flea is lark in colour, ancl, as in all fleas, is devoid of wings. The fleas are provided with very sharp piercing mouths. They are what 
are termed 'partial parasites'-parasites that only go to their losts to feed. The fleas are not noticed on the birds because they senerally attack them at night; then, however, they do much harm, causing constant irritation and loss of blood, and (lepriving them of rest."

"Lifi-history of Hon Flca.-The female flea lays her eggs (nits) chiefly in the nests amongst dust and dirt and in the crevices of the walls and floor. These nits give rise to pearly white nlaggots, with brown horny heads, which can often be founcl in the bottom of the nests amongst the dust. These larvae are mature in 2 or 3 weeks, then they reach about I- 6 of an incti in lens, In. In warm weather they may be full fed in even 10 days. They then spin a pale cocuon amongst the dirt, in which they pupate. The pupa is at first pale brown, then dark chestmut brown. In this condition the flea remains io to 2I days, when the pupa hatches into the adult. They breed all the year round, but chicfly in warm weather. It is well to remember that, whenever there are dark and dirty hen roosts. there are sure to be a number of Pulc.x gallinac."

Treatmint. These parasites do not usually occur under sanitary housing conditions. When they occur the houses should be cleaned and sprayed as for red mites (p. I34). Theobald recommends the use of excelsior or shavings instead of straw for nesting material as the fleas do not breed as readily in this material. 


\section{DISEASES OF TIIE SKIN.}

\section{Fains (Buldness or White Comb).}

This disease of the skin attacks poultry as well as man and the domestic mammalia. In mammals it is called tinca favosa or faz'us.

Diagnosis. The disease usually appears first as small gray white spots on the comb, wattles, eye lids and around the ears, that is, on the unfeathered parts of the head. 'The spots enlarge and rum together forming a scaly crust which becomes thicker until in 3 or 4 weeks it may be as much as 8 millimeters (I-3 inch) thick. The scales which make up the crust are often formed in concentric rings, the margins raised and the centers depressed, so that the scale is somewhat cup shaped. When the crust is removed the skin appears irritated and in places the surface is somewhat raw. The disease spreads to the feathered parts of the head, the neck, and the region around the vent. The base of the feathers becomes surrounded by concentric rings of the scaly material. The feathers become dry, erect, and brittle and finally break off or fall out leaving a disc-shaped scale with a depression at the bottom where the base of the feather was locaterl. 'The bird's head and neck and patclies around the vent become bare of feathers. The exposed skin is covered with the cup-sliaped scales. Sometimes the rlisease sprearls orer the whole body until the lirrl becomes nearly rakerl. The rliseased bird has a peculiar disagreeable odor. sometimes likened to the orlor of a musty grain or to mouldy

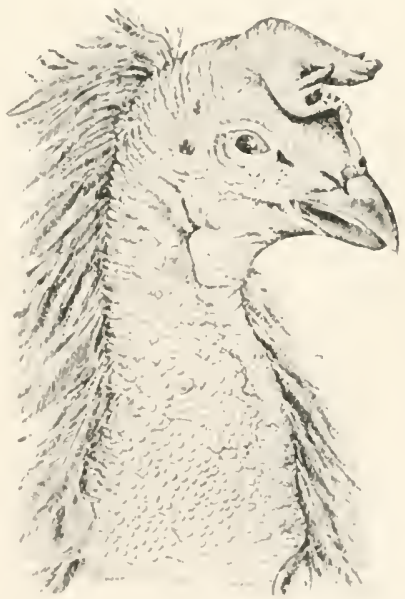

Fig. 37. Head and neck of a fowl affected with gencralized fav s. ( $\backslash \mathrm{fter}$ Pearson). 
cheese and sometimes to cat's urine or to macerating animal material. In early stages the general health does not appear to be affected but as the disease arlvances the bird loses its appetite, becomes poor and exhausted, and finally dies.

litiology. The discase is catused by the fungus Achorion schonlinii

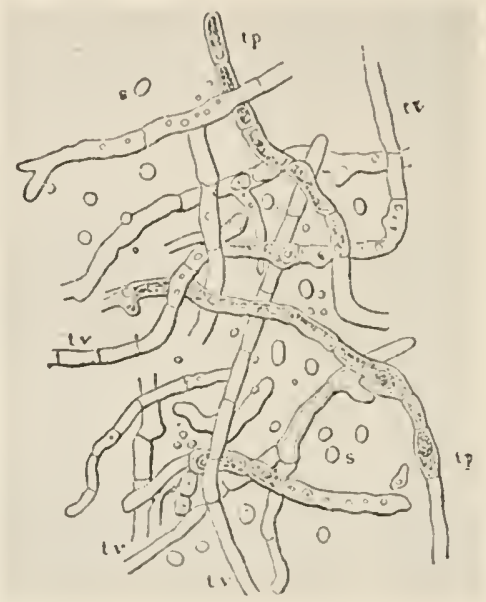

Fig. 38. The fungus Achorion schon-

leinii which causes favus in poultry. tr.-Empty tubes of nycelium. tp.-Tubes of the mycelium containing protoplasm and spores.

This fungus is found in the cup like scales on the skin and in the quills of the feathers of the diseased parts. If the favic cups or scales are moistened with weak acetic acid and cxamined under the microscope it will be seen that they are formed of branching, thread-like mycelial tubes of the fungus closely interwoven with one another, spores of the fungus, and epithelial scales from the skin of the host inlsedkled in a viscid substance secreted by the fungus. Some of the tubes of the mycelium contain spores. Many of the spores are found free among the filaments. They are usually found in groups of 3,4 or 8 .

Both the meclium and spores of the fungus are found in the quills of the feathers of the discased parts. The fungus sometimes penetrates even the barlos of the feathers.

Fatus is a contagrious disease and gets into a flock by the in- 
troduction of an affected bircl. It is less likely to attack strong, vigorous birds than those in poor conclition. It usually starts at a point where the skin is broken. Young birds are more susceptible than old ones. The large Asiatic breeds are specially liable to take the risease. No breed is entirely immune.

Megnin and some other anthors consider this disease distinct from the farus of man and other animals, but numerous recorded observations indicate that it is the same disease and may be communicated to man. In handling affected birds, therefore, care should be exercised to prevent infection of ents or seratches.

Treatment. Diseased birds should not he introduced into a flock. If the disease has been accirlentally introduced the affected birds should be isolated as soon as possible. The flocks should be watched in order to disenver and isolate any new cases that appear.

In early stages the disease yields readily to treatment. Ziirn considers treatment conomically advisable only before the feathered parts of the body are attacked. The disease may sometimes be cured at a later stage. The value of the affected bird must determine whether or not it is worth treating.

As much of the crust as possible should be removed. This is best clone by first softening the seabs with warm water or with oil or glycerine. Robinson recomments seraping with the back of a knife or a spoon hanclle. The parts should then be painted with tincture of iodine or should be bathed with corrosive sublimate solution, I part of the sublimate to rooo parts of water, and then rubling with the sintment described on p. 3o. In using the corrosive sublimate solution it shonld be borne in mind that this solution which unless colored with some dye looks exactly like water is extremely poisonons to men and animals when taken internally. Dishes or bottles of corrosive sublimate should never be left where they can be acciclentally mistaken for water.

Lard and sulphur are often used successfully in the treatment of farus. Use nearly as much sulphur as lard and work them into a smooth salve. In early stages the disease usually yiclds to application of lare or oil alone.

Prognosis. In early stages the farus may be cured at the expense of a small amount of attention. After the feathered parts lecome affected a cure requires considerable labor as the fungus is better protected from the applications. 


\section{IThite Comb.}

This name is often userl for farus, but some authorities (e. g., Vale) use it to designate a condition of the comb characterized by a white powrlery scurf of the surface. 'T'he comb is light colored and the white scales or flakes are particles detached from the epidermis. This condition is thought to be due to ancmia. Wright says that it "appears generally clue to dirt, or overcrowling in small space, or want of green food." 'The only treatment advised is to place the birds under sanitary conditions and give them a good balanced ration.

Chicken Po.r (Sore Hcad or Epithclioma Contagiosum).

'This contagious discase of poultry, althongh widely distributed in the northern states, is less common and serious here than in the Gulf States and Ilawaiian Islands. It is impossible at present to decide whether this is a distinct disease or a form of roup which affects the skin of the head. This can only be determined when further investigations have revealed the real canse of these diseases.

Diagnosis. The disease usually appears as warty nodules on the unfeathered parts of the head. They look like the tumors in the nasal passages and eye sockets of birds affected with roup.

Freidberger and Frohner* give a good description of these nodules on the skin of the head, as follows:

"Their farorite seats are those parts of the head that are not covered with feathers; root of the beak, neighborhood of the nostrils, angles of the mouth, lobes of the ear, parts adjacent to the auclitory meatus, wattles, surface of the face, edges of the cye-lids, intermaxillary space, and especially the comb. They sometimes spread over the feathered parts of the head, throat and neck, and may occur on the outer surface of the thighs, abdomen, under the wings and in the vicinity of the cloaca. At first these epitheliomata appear in the skin, as flat nodules. which soon become prominent, and which vary in size from a poppy seed to a millet seed. Later on, they usually attain the size of a hemp seed. They are of a reddish-gray or yellowishgray color, often show distinctly in their earlier stages of development a peculiar greasy, nacreous lustre; and are rather firm

*Freidberger and Frohner. Veterinary Pathology (Vol. I. Hayes trans ). Quoted from Cary. 
to the touch. Their surface soon becomes corered w ith a dirtygray, yellowish-brown or rel-brown crust. 'They are liscrete and discminated in considerable numbers on the erectile tis-

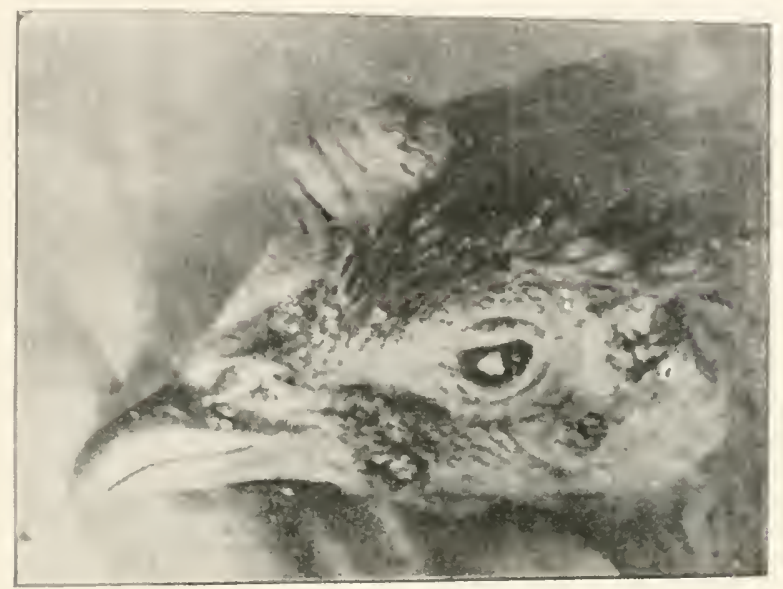

Fig. 39. Sore-head crusts on comb, eye-lids and skin (. Ifter (ary).

sues. cte. They vary in size accorling to their age: and frequently lic rather $\mathrm{cl}$, ee to one another, so that the affected parts look as if coarscly stantlated; or they are croweled together in such a manner as to give the appearance of large warts with divisions through them, or mulberry-like hypertrophies. Even single nodules, to say nothing of the groups, may attain the size of a lentil, pea, cherry-stone, broad bean or larger olject. The older they become the rougher. and more covered with knolss will be their incrusted surface."

"If the edges of the eye-lids be affected by these tumors, the lids will become norlular, swollen and closel. The conjunctiva in this case also suffers; it projects outwards because catarrhally inflaned; assumes a yellowish color at the seat of eruption; and its surface becomes covered with crusts. Purulent conjunctivitis may appear and the inflammation may spread to the sclerotic and cornea, with keratitis and panophthalmia as the result. If, as sometimes happens with pigeons, the eruption of nodules extends over the whole of the skin of the eye-lids and its neighborhood, the entire cye will become covered with mulherry-like proliferations of varions sizes." 
The presence of these molules on the epithelimm of the head is often (hut apparently not always) accompanied with characteristic roup lesions of the nasal cavities, moth and throat. As long as the disease is confmed to the skin of the hearl the general health of the bircl cloes not secm to be affected. Recovery may take place without treatment in from to to 20 days. The norlules in such cases dry ty and fall off. Ustally, however, the discase is not self-hiniterl. but advances. The eyes may become closed so that the birds camnot see to eat. 'They get fout and die from exhaustion. When the mucous membrane of the month developes diphtheritic membranes death occurs earlier than in other forms.

Etiology'. The lesions of this disease resemble the lesions of roup and many of the sane micro-organisms are found in the two cases. The organisms isolated from the lesions of soreliead inclurle several bacteria, a coccilimm, a yeast and several moulds. The coccidium, one of the moulds, and one of the hacteria have each been considered the cause of the disease by different workers. The real canse of the disease and its rela(ion to romp nust be determined by further investigations. 'The following discussion of the etiolugy of sore-head is given by Cary (Chicken-Pox or Sore Ilead in Poultry. Alabama Agric. Expt. Stat. Bulletin I 36 ) :

"Transmission and Disscmination. It is evidently infections; because the disease in all its forms. spreads rather rapilly. froul one chicken or pigeon to another. Warcl. Harrison and others have transmitted, in some cases quite readily by carrying small anount of diseased material (exulate and blood), from a sore-head chicken to healthy chickens. It is also quite certain that chicken pox and pigeon pox are identical or one and the same disease."

"Mosquitoes, guat flies, chicken mites (ticks), chicken lice, clicken foot mites (Sarcoptes mutans) and possibly cock-roaches may sometimes be carriers of the real virus. It seems quite certain that mosquitoes can transmit the virus from water or some wher sonrce, under certain conditions. Warm and wet weather seem to increase the virulency of the virus and favor the rapid transulission of the disease. It is not impossible that ants may have a rolc to play in the transuission or cause of sore-heat."

"Pathological Anatomy. On the skin the small, greasy-like modules, or hypertrophied nodules of the skin, contain epithelial 
cells that have in them "greasy" refractive bodies that stain yellow with picro-carmine and the nutele of the epithelial cells becone 'reldish hrown' in color. Nearly all the epithelial cells in the nolule appear larger than normal and contain the refractive bodies. In the younger epithelial cells these botlies (young coccidia ) are relatively small and occupy $1 / 4$ to $1-3$ of the epithelial cavity. In the olker or outer or cast-off epithelial cells these refractive bolies are said by Freidloerger and Frolner to occupy the entire cavities of the epithelial cells. The invaded or infested epithelial cells are unusually larger than the epidermal cells of the healthy neighboring skin. Among the cast-off mass of epithelial cells are found romml refractive bodies and numerous nuclei of leucocytes or pus cells. The subeutaneous connective tissue is hyperatemic (congested) and is infiltrated with cells (lencocytes and nuclei of disintegrated cells). Pussibly some of the small nuclei-like borlies among the cells in the subcutis may represent one stage in the development of coccilia. Many observers have, also, foumel various bacteria in the nofule and subentis."

"In the rliphtheritic membranes on the mucons surfaces of the moutl, pharynx, larymx and oesophagus, the epithelial cells are sometimes invaded by refractive borlies in the same manner as the epithelial cells of the skin and in the mass of cliphtheritic exuclate and cast-off cells on the mucous surface may be foumd the well formed coccidia $* * * *$. But the refractive bollies are not fonnd in the epithelial cells of mucons exulates uf skin nodules in every case. I luave found them only in the early development of the nodule and the diphtheritic exulate. and have never found the mature coccidium in the nodules of the skin."

"When the exuclate on the mucous surface or the crust of the nodule of the skin is torn off the raw surface bleeds rather frecly and a fresh mount of this blood contains a short oral bacillus. numerous round bodies nsually said to be nuclei of lencocytes; and a few polynuclear lencocytes. Repeated inoculations in the comb, wattles, skin and conjunctiva and oral mucosa of healthy chickens of various ages, with this blood. fresh from under a nodule or a diphtheritic exudate, has failed to produce positive infective results. I have also tester it on pigeons with like negative results." 
"'lhe exuclates on the mucons menbrane of the throat, month or larynx appear to be very much alike in all forms of the discase."

"The period of incubation is said to vary all the way from 2 to 20 days. In December I placed a newly-purchased barred Plymonth Rock cock ( 18 mos. old) in a yard with my chickens, many of which were recovering from sore-head, and in 24 hours this cock developed a good case of sore-head on the wattles, comb) and eyc-lids. There were mosquitoes in the roosting house. The period of incubation varies with mode of transmission, virulency of the virus, the weather (rapid in (lamp warm weather and slower in cool and (lry weather), and the age and condition of the chicken or pigeon. Chicks from broiling size up to 7 or $S$ months old seem to be most susceptible. Chickens with large combs scem to be more susceptible than birds with small combs and wattles."

Treatment. The introduction of diseased birds into healthy flocks shonld be avoided. The same precautions should be practised in the isolation of sick birds and disinfecting the houses as is advised for roup (p. 99). When the disease is localizerl a small amount of indiviclual treatment cures many cases. The crust or nodules shoukl be removed and the places treate? with crenlin ( 2 per cent solution) or corrosive sublimate (I-IOOO) (p. 29) and dusted with iodoform. The iodoform nuy be put into the eye. When the disease is not far arlvanced one such treatment may be followed by daily greasing with the ointment recommended on p. 30 or with vaseline or larrl. In bad cases the iorloform should be used daily for a few clays and then the ointment. When cases have roup or diphtheritic symptoms treat as recommended for roup (p. 100). Prognosis. "The mortality is saicl to vary from 50 to 70 per cent of the affected birls. I judge this a low per cent of losses ii bircls are left to themselves with proper care or treatment. But if individual treatment is patiently and regularly applied the mortality can be cut down to less than 20 per cent. If only the skin of the head, and the comb and wattles are involved, one should lose less than io per cent. If the month and pharynx are also involved, less than o per cent should die. But if the nasal passages and trachea are iurolved, or the intestines become involved,-good care and treatment may save 50 to so per cent." (Cary). 
Distases of the Reprodective Organs.

The direct economic importance of poultry lies in the production of two things, viz., meat and eggs. For the production of the latter the poultryman is dependent upon the activity of the reproductive system of the hen. Under natural conditions in the wild state, the progenitors of the domestic fowl laid relatively few eggs. Judging by other species of wild birds of the present day, however, it is highly probable that the wild progenitors of poultry possessed the potential ability to lay much more than the usual number of eggs provided they were removed from the nest as fast as laid. Under domestication this practice of removing the eggs as fast as laid, together with the feeding of rich foods, and still other factors, lays heavy demands upon the reproductive system. It is not remarkable that an organ system which under conditions of nature produced from I2 to perhaps 30 units per annum, frequently breaks down under the strain of producing from 100 to 250 per annum of the same kind of units. It could only be expected that, as is actually the case, the egg producing organs would be particularly liable to disease.

\section{ANATOMY AND PIIYSIOLOGY.}

In order that the discussion of the diseases of the reproductive organs may be intelligible it is desirable to preface it with a bricf account of the anatomy and physiology of the organs of reproduction in the hen. Because of the fact that the corresponding organs in the male are less subject to disease, on the one hand. and are perhaps better understood by the poultryman, becanse of the prevalence of the practice of caponizing. on the other hand, it will not be necessary to discuss the male in detail in this connection.

The organs concerned in egg production in the hen are shown graphically in fig. fo. This picture and the accompanying ex- 


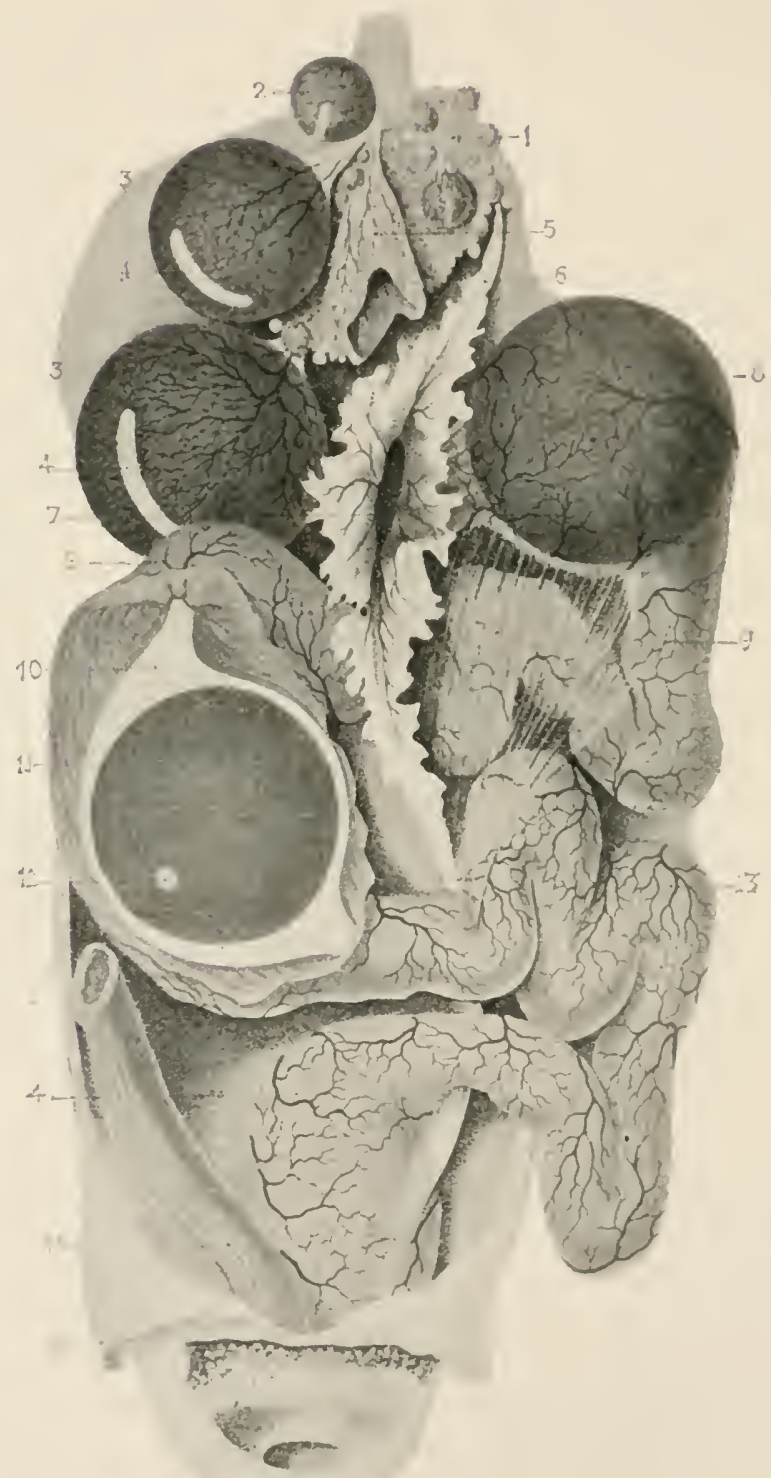

Fig. to. The reproductive or egg producing organs of a hen. See text for explanation of figures. (After Duval). 
planation of it will make clear the rarious parts of this organ system. All of the points shown in the figure may easily be demonstrated on a hen, killed during a period of laying activity. It should be noted that this picture is somewhat diagrammatic and not in accord with normal conditions in respect to at least two points. These are: ( 1 ) there are two eggs in the upper portion of the oviduct. Normally there would be but one there at a time. (2) The proportionate lengths of allumen portion, isthmus and uterus are not correctly indicated.

In this figure the varions numerals have the following significance:

I. 'The orary"; region in which the ovules (later to become yolks) are still small in size.

2. An orule in an intermediate stage of development, larger than those at $I$, but still not ready to pass into the oviduct to be laid. It is contained in a very vascular capsule, known technically as the follicle.

3. 3. Ovules still larger and containing more yolk. The lower one is nearly ready to leave the ovary and pass down the oviduct.

4. It will be noted that on all the larger follicles there is one region (forming a line) in which there are no blood vessels. This region $(4,4)$ is known as the stigma. Here the follicle wall breaks and allows the ovule (yolk) to leave the ovary preparatory to laying.

5. An empty follicle in which the stigma has openerl and the yolk passed out.

6. Anterior end of the margin of the funncl (or infundibulum) of the oziduct or egg-tule. When an ovule is abont to be discharged from the ovary these funnel lips or margins wrap around that portion of the ovary, so that the ovule may certainly pass into the oviduct and not into the abominal carity.

7. Opening of the funnel. Through this opening the yolk passes into the oviduct.

8. A yolk which has just passed through the funnel opening into the upper portion of the oviduct.

9. 9. Albumen secreting portion of the oviluct in which the greater portion of the allumen or white of the egge. is secreter by glands in the walls of the oviduct in this region.

IO. First layer of albumen, or white, secreterl about the yolk. 
From this layer are formed the chalanac, or cords of twisted. thickened allumen, at each pole of the sulk.

11. Jolk, around which albumen is being secreted.

12. The germinal disc. This is the living portion of the egg, from which the future chick develops, the main mass of yolk serving as food material for the developing embryo during the process.

13. Anterior end of the isthmus of the oviduct. The primary function of the isthmus is to secrete about the egg the sholl mombranc, the dense white membrane closely adherent to the insicle of the shell of an egg.

14. The utcrus, or shcll gland, in which the shell is put on the egg.

15. The rectum.

16. The walls of the abdomen cut and folded back.

17. External opening of the cloaca, or common space into which open (a) the rectum, (b) the oviduct and (c) the ureters, or kidney ducts.

The processes concerned in the formation of an egg are thus summarized by Lillic (The Development of the Chick, New Jork, I9o8, pp. 23-25):

"The formation of an egg takes place as follows: The yolk, or ovum proper, escaped by rupture of the follicle along a preformed band, the stigma (fig. 40), into the infundibulum, which swallows it, so to speak, and it is passed down by peristaltic contractions of the oviduct. The escape of the orum from the follicle is known as the process of orulation. During its passage down the oviduct it becomes surrounded by layers of albumen secreted by the oviducal glands. The shell-membrane is secreted in the istlmus and the shell in the uterus (fig. 40). The orum is fertilized in the uppermost part of the oriduct and the cleavage and early stages of formation of the germ-layers take place before the egg is laid. The time occupied by the ovm in traversing the various sections of the oriduct is estimated by Kölliker as follows: Upper two-thirds of the oviduct about 3 hours (formation of albumen), isthmus about 3 hours (secretion of shell-membranc), uterus 12 to 24 hours (formation of shell and laying). These figures are only approximate and it is obvions that they are likely to vary considerably in different breeds of hens." 
"Some of the details of these remarkal)le processes deserve attention: The observations of sereral naturalists demonstrate that the ripe follicle is embraced by the fumnel of the oviduct before its rupture so that the ortum does not escape into the body-cavity, but into the oviduct itself. Coste describes the process in the following way: 'In hens killed 17 to 20 hours after laying I have observed all the stages of this remarkable process. In some the follicle, still intact and enclosing its egg, had already been swallowed, and the mouth of the oviduct, contracted around the stalk of the capsule, seemed to exert some pressure on it, in other cases the ruptured capsule still partly enclosed the egg which projected from the opening; in others finally the empty capsule had just deposited the egg in the entrance of the oviduct.',

"The existence of double-yolked eggs renders it probable that the oviduct can pick up eggs that have escaped into the bodycavity. Lut in some cases ora that escape into the body-cavity undergo resorption there."

"Immediately after the ovum is received by the oviduct it appears to become softer and more flexible (Coste). The uppermost portion of the oviduct then secretes a special layer of albumen which adheres ciosely to the vitelline membrane and is prolonged in two strands, one extending up and the other lown the oriduct: these strands become the chalazac; the layer to which they are attached may, therefore, be called the chalaziferous layer (Coste) of the albumen. The ovum then passes down the oviduct, rotating on the chalazal axis, and thus describing a spiral path; the albumen which is secreted abundantly in atvance of the ovtum is therefore wrapped around the chalaziferous layer and chalazae in successive spiral layers and the chalazac are revolved in spiral turns. The main factor in propulsion of the orum along the oviduct appears to be the peristaltic movements of the latter; it is probable that the cilia which line the carity have something to do with the rotation of the orum on its chalazal axis."

With this account of the anatomy and physiology of the female organs of reproduction in hand we may proceed to a considerations of their discases. These diseases fall at once into two classes: (a) those affecting the orary and (b) those affecting the oriduct. 
DHSH.ASFS OH THY (M.IKS.

Atrophy of the Ociely.

By "atrophy" of the ovary is meant a diminution in size of that orean accompanied with a cessation of its physiological activity. It may shrink to the size and appearance which it has in a very young bird. 'The following sorts of atrophy of the ovary may be distinguished. 'The different sorts are separater from each other, not because of any difference in the end result. but because of the different etiological factors concerned.

I. Phỵsiological atrophỵ.

a. 'Temporary.

b. Permanent.

2. Congenital atrophy (Psendo-hermaphoditism).

3. "lilack atrophy."

A physiological climinution in size or partial atrophy of the ovary occurs normally in fowls when after a period of laying they go into a more or less prolonged resting period. The condition of the ovary is uswally (in fowls under 2 years old) only temporary. The organ resumes its normal size and activity after a time. In old birds (3 to 6 or more years of age) it not infrequently happens that the ovary passes into an atrophicel condition, and remains permanently in that condition thereafter. In such cases the bird as a whole, and the ovary in particular. may be perfectly healthy, showing no sign of discase. Cases of permanent physiological atrophy of the orary have been observer at this Station as follows:

One case in a White Crested Black Polish.

One case in a Comish Indian Game.

Several cases in Barred Plymouth Rocks. All of the latter were birds of very high fecundity (200 or more eggs per anmum) in their pullet years.

It should be noted that in what is here called permanent physiology atrophy of the ovary there is no associated change of the secomdary sexual characters. That is, the hen does not assume cock plumage, spurs. enlarged comb and wattles, nor any other of the secomdary sexual characters normal to the male. 'This indicates that in permanent physiological atrophy (just as is known to be the case in temporary) the only function of the ovary which is clisturled is that which is involyed in egg formation. 'The activity of the organ in regard to producing an 
internal secretion which in some way controls the secondary sexwal characters remains unchanged.

As congenital atroplyy of the ozary are to be classerl cases of psenilo-hermaphroditism in fowls. In such cases a true. functioning ovary never develops. 'There may be a boty which in gross features resembles an ovary, but it is inactive and does not take eren the first steps in oogenesis ( $\mathrm{egg}$ formation).

There may or may not be a testis like body present in these cases. Not only is the egg producing activity absent in such cases, but also in many of them at least, the internal secretion normally produced by the ovary is lacking also. The bird then takes on some or all of the secondary sexual characters of the male. The appearance of such a lird is shown in fig. 41.

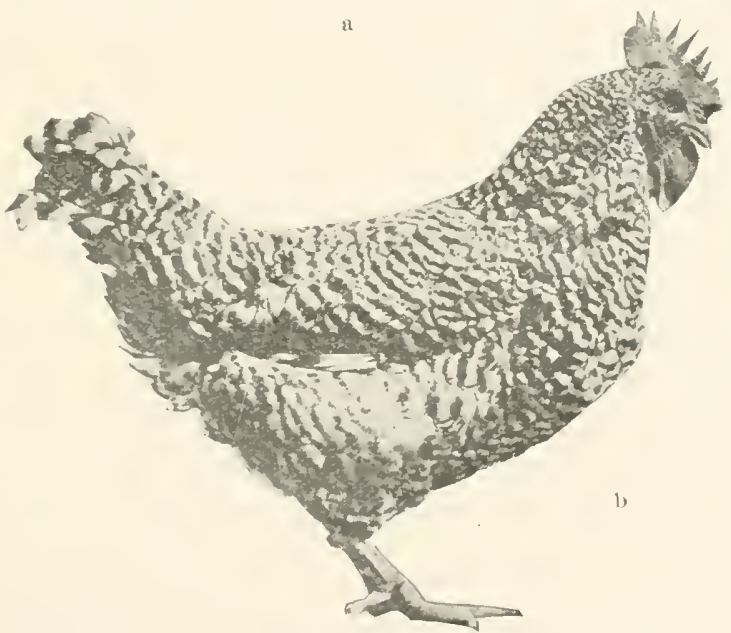

Fig. fI. Showing a case of incomplete hermaphroditisn. In front $n$ the line $a-b$ the bird has the characters of the male, behind it the characters of the female. The orary was not functional in this bird. (Original).

As "black atrophy" of the ovary is here designated the peculiar disease of the orary first observed more than a century ago in England as occurring in pheasants. The striking feature of the discase is that under its influence the bird assumes the plumage appropriate to the male. The change in the ovary and oviduct induced by the disease appears to be an atrophy accompanied by a blackening which is probably a true melanosis. The following account of an outbreak of this disease about 50 
rear ago. written by llanilton (1'roc. \%ool. Sioc.. L.onchon, 1862, P. 24) is of interest: "In the years 1858.1859 , ant 1860 this peculiar alteration of structure in the female organs of generation in the l'leasants was particularly prevalent in some parts of finglancl. I had the opportminty of examining many specimens, and was able completely to confrom .1tr. Yarrell's views on this sulject. Indeed, the majority of the birds were young females, many of them being birls of the year, some being in their lirst monlt. I found also that the plumage varied and approacherl that of the male, not in accorlance with the age of the birl. but with the amount of clisease of the generative organs. The greater the destruction of the ovarium and oviduct. the nearer the plumage assimilated that of the male."

"For example, in birds with the hen-plnmage predominating, the orarium and oviduct exist as in the fecundating hen, the small ova lying in considerable nmmbers in the ovarimm, the ovarinm and oviduct showing dark lead-colonred masses of discasc."

"In birls with the plumage of the male in a measure exceeding that of the female, the ovarimm is considerably diminished in size, dark-coloured, and containing only a few blackened ova; the oviduct is spotted with elark patches. and considerably contractell."

"And thirdly, in birds with the male plumage predominating nver that of the female, the ovarimm is reduced to a small dark amorphous mass, resembling the coagulated bloorl, the presence of ova cannot be detected, and the oviduct is almost entirely obliterated at its junction with the ovarimm. Thus it seems that there are 3 distinct phases in this peculiar abnormal state of the gencrative functions."

"I have also noticel that, in most cases where the male plumage is in excess of the female, the tail-feathers are particularly long, sone being ats much as 19 inches in length."

"Although Mr. Yarrell states that this condition of the female generative organs is not confined to the Phasiandac, and that it has occurred in the gold and silver pheasants, partridges, peafowls, common-fowl, common pigcon, king-fisher, and common duck, and that other classes of animals are liable to an influence similar in kincl, particularly among insects and Crustacea, yet this disorganization is rarely olserved except among the Phasianidac, and particularly when these birds are produced in a do- 
mestic state, i. e., on the present system of breeling pheasants in preserves. Very few battucs take place in which some of these birds (exenerally designated males) are not killed and mixed indiscriminately with the heaps of the slain."

. As to the cause of this disorganization, if it occurred only in the old female, or if it were a common occurrence among birts either of different genera or of the same genns, it conlel be easily acconnted for: but when it is generally found existing annong a class of birds which are bred in vast numbers in a particularly artificial manner. it leads one to suppose that the canse must be connected with this condition."

In regard to all sorts of atrophy of the ovaly it should be said that there is no known way to treat them. Such cases when they appear must be accepted by the poultryman as one of the vicisitules of the business.

\section{Gangrene of the Oiary.}

Salnon and other writers on poultry diseases following him have designated as gangrene a condition of the ovary relatively often found at post-mortem. Salmon's discussion of the matter is as follows: ".This disease is quite common with all varieties of ponltry. On examination of the ovary after death, the ora are found in different stages of derelopment, but instead of being yellowish-pink in color, with the blood ressels well defmed, they are brown or black, easily crusherl and the contents broken (lown into a putrid liquid. Death is caused partly by peritonitis and partly by the absorption of the protucts of decomposition."

"The cause of this trouble is not well unclerstorl. It has been attributed to the birds being too fat thus compressing the ovary and hinclering the evolution of the ora. Is it may occur in birds which are not fat and as it is evidently accompanied by the penetration and multiplication of bacteria, it is possibly an infectous disease."

We have unt been able to find anywhere in the literature that there has been a thorough investigation of this clisease.

\section{Oiarian Tumors.}

Tumors and cancerous growths on the oyary are not uncommon. These include several sorts of interest to the pathologist. but not to the practical poultryman. From the literature it ap- 
pears that at least the following (and probably other) kinds of new srowthe are fomel to occur on the ovary with greater or less frequency.

1. Penign tumors, of several types, including yolk tumors.

2. Carcinoma.

3. Dermoid cysts.

"Treatment is, of course, impossible in these cases as the nature of the discase is not determined until after the bircl's cleath. If such abmormal conditions are frequently found, it is an indication that there is a preclisposition in that direction in the strain of lirels. The only way to correct this is to kill off the flock and olstain different blood." (Salmon).

$$
\text { Abortion of Eggs. }
$$

Regarling this matter Wright (New Book of Poultry. p. 574) has the following to say: "This is not to be confounded with the laying of soft eggs. These last are laid when mature, and usually by fat bircls; but when violently driven or startled, or subject to violence of any lind, or even if suddenly and great1y terrified, immature yolks are sometimes detached from the ovary and expelled. This is most likely to happen with pullets not yet laying but about to lay, and being a real miscarriage or abortion, may wreck the constitution of a valuals]e bircl unless attender to. It is distinguished from the other by not occurring as a rule in fat birds; by the immature and small size of the yolk or yolks; generally also by hemorrhage; and always by signs of illness of chicks afterwards. Any such bird shonld be placed for a few days in a quiet and comfortable but rather dark pen, witl a nest in ease of neecl, and feel on a little bread and milk. Quict rest is the main thing. but 20 grains bromide of potassium may be clissolved in half a pint of clrinking water. With such care the event may be entirely recovered from."

Yolk Hypertrophy.

There are a number of cases on record where the yolks formed by the ovary lave been very mucl larger than normal. These "giant yolks" are due to a diseased condition of the organ, possibly contingent upon too much forcing for egg production. Such cases have been described by Gurlt (Mag. f. d. ges. Tierheilk, 18.49) and more recently by ron Durski (Die pathol. 
Verändernngen des Eies und Eileiters bei den Vogeln. Berlin, 1907). When yolks become very large in this way they may break loose from the ovary withont any rupture of the follicle wall along the stigma but a breaking or tearing loose of the stalk or perlicle of the follicle.

\section{Failure of Follicle II all to Rupture.}

Closely connected with the last discased conclition is one discussed by ron Durski in which the follicle wall fails to rupture and rclease the yolk. In consequence of this, in the case described by ron Durski, the follicle wall became stretched and pulled ont into a long and very much tristed stalk. 'T'his stalk helel the hard, and decayed yolk fast to the ovary. In cases of this kind the stalk sometime's breaks, and the yolk enclosed in the follicle and with the end of the stalk attached, passes down the oriluct acquiring allumen. membranes and shell. In still other instances the stalk breaks and the follicle and contained yolk drops into the abdominal cavity.

\section{DISEASES OF THE OVIDLC'T.}

Diseases of the oriduct are relatively common and cause a steady: and probably in the aggregate rather large loss to the poultryman. Fortunately some of the diseases of the oviduct are more amenable to treatment than are those of the ovary. Further these discases in many cases show plain external symptoms at a relatively early stage. Then they may be recognized and treated while it is till possible to effect a cure. This is nsually not the case with ovarian diseases.

The general external symptoms of the commoner diseases of the ovi.huct are very much like those of constipation. The poultryman watching his birds is incled rather likely to confuse the tivo. lint if so no harm is done. The thorough cleaning out of the alimentary tract, and stimulation of the liver indicated in the treatment of constipation is the very best thing to be done in cases of inflammation and similar disorders of the oriduct.

\section{Inflammation of Oriduct.}

This is one of the most important and common diseases of the oviduct. It may occur alone or in association with other morbicl conditions of this organ. 


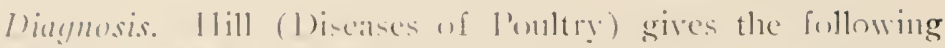
symptoms: *-A hird affected with inflammation of the egres passate suffers ateutely. It lirst there is a continual and riolent straning (sonsetines resulting in apoplexy). The wings are dropperl and the feathers pufferl ont. The vent is usually hot and if a thememeter be inserted the temperature will be fomed high, frepuently 105 to 10 \% legreses. As the inflammation procoels the birel becomes more and more mopish and exhatusted lut does not strain so violently, pain and exhaustion acting as preventatives. Cltimately the temperature becomes lower. the boly colel and with a few, convulsive gasps the sufferer dies."

Th these symptoms salmon athls the following. basing his account largely upon the statements given by Zürn: "lhe bird at first shows inclications of a desire to lay withont being able to profluce egsis or it may lay egge containing more or less bloor or exgs without shells or small and misshaped eggs containing albumen lut no yolk. or fmally the yolk may be dropped without any covering of allumen or shell. As the infammation increases there is high temperature, straining and an effort to rub the abdumen mon the gromul. In later stages the bird becomes (lull, indisposed to more, the comb is pale, the plumage rough and the temperature falls to normal or bekw."

Iitiology'. There are probably to be distinguished three classes of canses which lead to inflammation of the oviduct. These are:

1. I'hysological; from irritation the to too frequent laying or from too stimulating foorls or comliments.

2. 'Tramatic; from irritation lue to tox large eggs, or to the breaking of eggs within the oviduct, or similar causes.

3. Specific infection: it is probally that alome or in combination with the canses classed muler 1 and 2 a specific infection of the linine membranes of the oviduct may ocenr.

In an inflaneel oviluet there very often is a copious sero-fibrinons exulate. This hardens about any foreign body (egg, broken egg. (te.) which may be in the oviduct, and by aceretion cances this foreign body to increase in size. This, of course,

*'There must be some mistakic about this. $105^{\circ}$ to $107^{\circ}$ are $110 t$ at all ligh temperatmres for the domestic fowl. In fact in our experience at this Station ro $5^{\circ}$ would seem to be a slightly subnormal temperature rather than one inclicating ferer. 
makes it still more irritang which in turn provekes further inflammation of the walls of the duct. One sometimes fincls relattively chormuns mases of material in a diseased oviduct. which have heen built "p in this way. There is an extensive literature on these "egge concrements" or "yolk tumors" built 11p either in the oriduct or in the abdominal cavity by hardened fibrons exudate, abont an original basis of a broken, or miscarried. or aborted yolk or yolks. It is not necessary to review this literature here as it is only of interest to the specialist.

Treatment. If this discase is to be lealt with at all the treatment must be inelividual, since it is something which will nerer affect considerable numbers of the flock at the same time. If individual treatment is to be suceessful it must be begun at a relatively early stage of the disease. 'Therefore, it is inuportant that a hirel showing the symptoms which have been described above shonld be isolated at once and as a first step in the treatment given a purgative lose of Epson salts (see p. 29). All stimulating foods sucl as meat, green cut bone, linceed nea! and similar substances, as well as condiments like condition powers, pepper. etc.. should be immediately taken away from the birel. A light ration and plenty of green food shonld be given. Salmon recommencls following the purgative with $\mathrm{I} / 2$ clrop of tincture of aconite root 3 times a day. Equally effective, and much casier to alminister, will be foumd I-IO gr. aconite rot tallets (see p. 30).

\section{Prolapsi of the Oriduct (Eicrsion).}

It not infrequently happens from one cause or another, that the lower portion of the ovieluct becomes everted and projects from the vent as a mass of red or purplish tissue. 'This condition is known as prolapsus of the oviduct

Diagnosis. The diagnosis of this diseased condition is simple and comsists merely in the olservation of the prolansed oviduct. If there is a mass of red or bloody tiscue ; rojecting from the vent one is safe in cliagnosing proliapsus. The only point which neerls particular attention in the diagnosis is as to the degree to whel prolapsus has oceured when the bird is discoveres. The importance of this lies in the fact that on it depencls the treatment which it is arlvisalble to sive. Where the prolapese is only: partial and is discovered early it is advisable to treat it ly the methols outlined below. If, on the other hand, the prolapse is 
(x)ensive and has existed for some tine before the bird is seen $\because$ that the mass of tissue las turned a blue or purplish color or has been pretty extensively pickerl and torn by the other birls in the pen, then it is weless to carry on any treatment and the frroper thinger wo do is to kill the biril at once.

litiology'. P'rolapse of the oviduct may be cansed by a numlue of different things. It is observed not only in old hens, but. in our experience, quite as frequently in pullets. The fundamental cansic of the condition is, of conrse, a weakness of the oviduct walls, and liganents, chiefly in respect to their muscular portions, which makes the oriduct mable to stand the strains put upon it in egg production. The immediate canse may loe cither:

I. Straining to lay a very large (double yolked) egg. This is perhaps the most common canse.

2. Straining to lay when there is an obstruction in the oriduct (egg bound).

3. Constipation. The rectun full of harlened feces stimnlates all organs in that region of the body to expulsive reflexes.

4. Zürn says that often times feees may become lorlged in the cloaca in a sort of blind pocket, and then set up the same expulsive reflexes as an egs in the cloacal or vaginal regions normally does. In the effort to expel this foreign body the oviduct may become everted.

The most serious thing about prolapsus is that if not discovered very shortly after it occurs it is ahnost sure to result fatally, becanse the everted portion will become so badly infected as to catise blood poisoning, or the protruding mass of tissue will be picked and torn by the other birds in the pen until there is 10 hope of repair, whatever the treatment.

Treatment. As stated above, the alvisability of treating prolapsus depends upon its degree and duration before discovery.

In treating this condition the first thing to endeavor to do is to remore the canse. That is, if the bird is constipated give it a rectal enema of warm soapy water, followed by $1 / 4$ teaspoon of Eipsom salts by the mouth. If there is a lmmp of feces lodged in the cloaca this should be carefully removed. The protrucling mass of tissue should be washed with warm I to Iooo bichloride of mercury solution, or a warm $1 / 2$ per cent cresol solution. After the protrucling parts are thoroughly cleansed they should be well greased with vaseline, or with the ointment already recont- 
mended (p. 30). Then with the fingers well greased an effort hould be made to replace the protruling mass in the body. In doing this one shonlel proceed with the greatest gentlenes. In must cases with are and patience it is possible to reduce the prolapsus, that is. to get the extruc!ed tissuc back into the body in approximately its normal position.

After the parts have leen carefilly replaced in mormal position the next point to be considered in the treatment is to insure that they hall tay there. 'That is to say, it is necessary some way $($, bring absut a healthy degree of contraction of the muscular walls of the oriduct so as to h ld the parte in place permanently. In order to lo this Salmon recommends the nse of ergot. Robinson follows Salmon in this recommendation. It should be said, however, that it is doubt ful whether this treatment is arlvisable. Eirgot is a rather violent poisnn for poultry. [t secms likely that the treatment recommended by Salmon and Robinson is based on a theory that the action which ergot has on the mammalian uterus will be duplicated on the fowl's ovidict rather than upon actual experience in administering the drug to poultry. The measure recommenced by Zürn to bring about a healthy contraction of the replaced oriluct in cases of prolapsus would seem to be simpler and on the whole more likely to yield desirable results than the ergot treatment. Zuirn recommenels that a lump of ice be placed in the cloaca after the prolapecl oriduct is returned to its place and that this treatment be followed up for some hours.

The bird shoull le kept in a small coop, partly darkened. where there will be every inducement for it to remain perfectly quict. The success of the treatment depends very much on keeping the bird quict for a few days. It should be fed only a light and unstimulating ration with plenty of green food.

Prognosis. If discovered early enough prolapsus is curable.

Obstruction of the Oriduct ("Fing Bound").

Perhaps the commonest of all diseased conditions of the oriduct is that which leads the poultryman to say that a bird is "ege bound." liy this is meant that there is something in the ovilluct which the bird is not able to pasis to the outside and which in turn prevents the normal passage of eggs. In many cases this is not properly speaking a diseace at all but rather an accilent. Other cases, however, depend npon a true discased enndition of the oviduct. 
Dinenosis. Salumen fencribes the follenting symptoms:

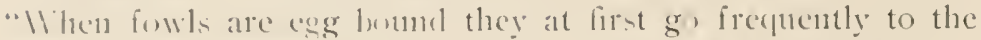
nest. making efforts (o) lay but are muble to acomplish this function. They are restless and eviflently in more or less distress. latter they lecome dull, with rough plumage and are inclinposed to move. On examining the birel by pressure of the finger alunt the vent, the egre ean be distinguished as a harel burly in the posterior part of the aldeminal cavity. In case of prolapsis, the everted oviduct may he easily seen."

In this connection. however, it should be noted that these general symptrms which Salmon describes are observed in mild form in a sreat many catses with birds which sulsecpuently lay the egg without trouble. In many instances the extrusion of an egg which is finally successfully lairl is attenderl with a good deal of difficulty. There are all degrees of grarlation between this sonewhat difficult but still normal laying and the condition of complete obstruction of the ovicluct where the egg cannot be passed at all. The practical consideration to which this leads is that cme should not be too hasty in applying treatment for the ergy-bound condition. A diagnosis of the trouble, in other words, should not be finally settled 11 pon until there remains no (loubt that the hen is not going to pass the egg without help from the ontsile.

It must also be remembered that in many cases of obstruction of the oviduct, the obstruction is so far up that it cannot be felt from the outsicle. In such cases the diagnosis must be made unom the general behavior of the hen, and in particular in regard to going frepuently on the nest without laying.

Etiology: In considering the causes of obstruction of the oviduct it is necessary to distinguish between several clifferent sorts or categories. This may be done as follows:

ı. Simple "egg bound" condition, in which a normal egg is forlesel in the uterus or vagina and cammot be expellect. This inaluility to expel the egg may be clue to any one or a combination of the following catises acting together:

a. Eigg of too large sime, so that it is mechanically difficult or impossible to force it through the natural passage. Robinson regarts this as the most common cause.

1. Fxhaustion (true phrsiological fatigue) of the muscular walls of the oviluct. This conclition results after long continued and musuccessful attempts to expe lthe egg. It leads to 
c. Atony and paraly is of the duet in which the musetilar walls are incapable of making any effective contraction at all.

2. Complicated "egg boume" conclitions in which the funclamental somece of the trouble is not simply mechanical, and in which ustally the portions of the oviduct anterior to the nterus are involver. In this general categery the following sorts of cases are to be incluclecl.

a. Atony and paralysis of the upper portions of the ovifluct. 'This condition may exist for a long time withont heing' recognized.

b. Inllammation of the oriluct learling to tac formation of fibrous exulate which accumulates in the duct, until it may form a mass of relatively enormous size (ustally with one or more rolks as a melens) completely obstructing the duct, and eventvally leasling either to gangrence or rupture of the walls, or both.

c. Volvolus or twisting of the oviduct alout its own long axis, completely obliterating the cavity.

d. Stenosis or stricture of the oviduct. 'This may result from several causes. One frequent one is that in laying a very large egg the oviduct wall becomes torn to greater or less degree, and subsecuently heals. The scar tissue contracts the carity and a stricture is thuts caused.

Tratmont. Whether treatment is or is not likely to he effective depends npon which of the two main categories above defined any given case belongs to. Simple olstruction of the oriduct may be sucesssfully treated. In cases of complicated obstruction treatment is not indicated, for a variety of reasons. These conditions are in the first place difficult to diagnose, and offer little prospect of sncecesful cure eren after a diagnosis has been made.

The best arlvice which has come to our attention for the treatment of the simple egg bound condition was publisherl some years ago in the English Journal "P'oultry" and is here quoted verlotim :

"It is a good plan to watch those birels that are about to lay. Shoukl they visit the nest frepuently during the course of the (lay and leave without depositing an exg. it is almost certain that something is wrong and when a pullet is in such a state there are three good remedies that ma le tried. The first is: T'alie the bird up gently, and holel her so that her stern is over the mouth of a jug of boiling water, that the steam arising there- 
from maly gere to the parts and help) to relax and procure deliv-

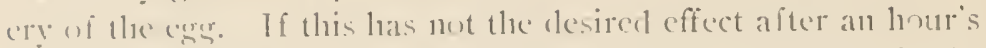
rest in a (puict coop), the vent shemlel he oilerl gently with a feath('1. and the lien siven a puwere composed of I grain of calnmel and 1-1 2 grain of tartar ennetic. 'The powder may le mixed in a bolus of fond, and put into the bird's crop. If it be acting properly a merkerl improvenuent should be noticeable in the lirel a few hums afterwarels, while a second powrler wiven two days subsequently will probably enmplete the cure. It is advisable for a while to feed the fowl sparingly on a somewhat low clict. Withlodding any fat forming food. and giving linc-water to clrink, after the system is rid of the powder. 'The second remedy was adrocated by Dr. H. B. Greene, * * * * * * ancl is best applied when the egg can be felt. It is:- Let an assistant, seated on a chair, hold the hird firmly on his knees on its liack, with the vent directed away from him. Seating yourself opposite, with the finger and thumb of the left liand ontsicle the bird's body. push the egg firmly but carefully towards the vent, until it is plainly visible, and, leeping it in that position, with a bradaw in the right hand puncture the egg shell, cracuate the contents of the egg with an egg-spoon. and afterII ards with a pair of tweezers break down and take ont the shell piece ly piece until assured by passing the finger into the vent, that the cloaca is enpty. Special care must be taken to aroid injuring the bird with the point of the awl; and one s assistant must maintain a steady and firm hold on the fowl. A thiril method of relieving an egg bound hen was recommended by a correspondent in our issue of June IO, ISgS. and has since been irequently tried by several poultry keepers, and found very cfficacious. Then a hen is in that state I hold her over some hot water, hathing the rent at the same time. After this I use a small penknife (blunt) in the following manner:-Placing the eclge of the blatle along the first finger so that the end is level with the funger end, I push the finger with the knife into the vent until they touch the egg: then I begin to scrape until I hear that I have scraped the rind or skin aray from the egg (I mean ontside the egg). The hen is then placed on the nest, and I will gruarantec she will lay in 20 minutes, or in most cases even less than that. I got this arlvice from a man who has kept poultry on a small scale for 5o years. I have tried it several times, and have never known a hen to be egg bound a second 
time. 'l'his method, it would appear, saves the eger. 'The great thing throughout is to keep the bird quict, and in future to avoid extra fat forming food.'"

Prognosis. Cood in cases of simple cobstruction if taken in hand carly; had in all cases of complicated obstruction.

$$
\text { Rupture of the Oiduct. }
$$

In some cases of complicated obstruction, and in cases of serere inflammation the walls of the oviluct may break and allow the contents to escape into the abdominal carity. In such cases death usually cnsues in a relatively short time as a result of peritonitis. These cases are incurable; indeed the trouble is usually not known till after the bird dies. The lower portion of the oviduct (ragina) or the cloaca may be ruptured in passing a very large egg. If the wounds marle in this way are relatively small they will usually heal without any trouble. If, on the other hand, such tears are extensive they may very easily become infected, and unless treated properly in accordance with the general directions given in Chapter XX for the treatment of wounds. the bird will die of blood poisoning. Regarding cases of this kind the following excellent discussion (presumably written by Mr. J. H. Robinson) appeared in Farm Ponltry some 6 years ago (Tol. 16, p. 230). The writer says that this trouble of rupture of the oviduct near the vent he "used to have with Buff Leghorns, and to a lesser extent with other varietics of the Leghorn. Leghorn hens quite generally lay larger eggs in proportion to their size than others. Some of them lay eggs very much larger in proportion to their size than layers of large eggs in the larger breeds. As a result of this the difficulty of laying is correspondingly increased. When a pullet begins to lay she may lay small eggs, which are easily passed. As warm spring weather comes she lays more eggs, and also larger ones. Suppose one day there is a slight tear or a strain on a part of the oviduct in laying. The part is not badly damagerl, but it is sore, a little inflamed, and cannot be stretched as it was before to permit the passage of the egg. Iut the egg is there and must be extruded. A larger tear in the parts is the restult. There may be hlood enough flow to make the egg quite bloody: but the injury be not yet serious. Nith the next egg conditions are still less favorable for a safe extru- 


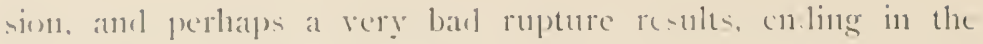
conr:c of a few days fatally."

"I llow't think it profitible to attempt to treat such cases. simuc cures may be effecterl, but it is not always easy to clieck laying without starving the hen, and even that treatment may

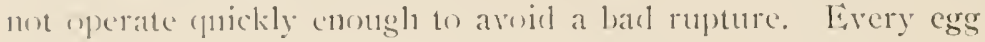
pasicel while the vent and aljacent parts of the passage are not in nomalal conclition is a possible canse of fatal trumble."

"The best way to treat this trouble is to prevent it by selecting medium sized eges for hatching. Select brecelers of good size; select or ood lut wot excessively large egess from these; use males from stuck of the sane claracteristics. and avoid the use of males (and of hens too) that are narrow horlicel."

\section{Gangrenc of Oilduct.}

'l'his may result from severe and complicated obstruction. What is nueant by "gangrene" is that the walls of the ovidnet die, and putrefy. 'l'his causes general blood poisoning from which the bird dies. Ciangrene of the oviluet most frequently follows severe cases of complicated olstruction where there is a matis of filmous crudate deposited in the oriduct. 'There is not the slightest hope of successfully treating such cases.

$$
\text { Brating of ligg in Oilduct. }
$$

It sometines happens that an egg in the mpper portion of the (wirluct, before it has acquired any shell, is hy acciclent broken. There is a belief common anongst poultrymen that this is always immediately fatal. There is but little discussion of the subject in the literature but our experienee here inclicates that two sorts of resilts may follow the breaking of an egg in the ovicluct. 'I'hese are:

I . In inflammatory condition of the oviduct is induced leading to coprous secretion from the glands of the albumen portion of the duct and the istlumus. There is also a copious fibrous exuclate. and the final outcone is a severe case of complicated obstruction of the oviduct. Death in these cases may be delayed for a long time after the original accident. In the absence of inflannution recorery may possibly occur.

2. 1)eath within a slort time ( 2 to 3 hours) after the breaking of the egre, withont visible lesion of any organ of the body. The oviduct is not even infamed. Absolutely the only things 
which are not normal in such cases are (a) the broken egeg in the oriduct, and (1)) the fact that the bird is dead. Ne have hat several such cases come to antopsy. They are very puzzling. In then is to be foumd the basis for the poultryman's belief as to the fatal character of this acciclent. In reality it scems probable that in these cases the thing which cansed the ege to be broken was also the canse of the death of the bircl. That is, a blow, or any sort of sudten shock riolent enongh to break an egg in the oviduct might also very well be the cause of death. Such cases need further study.

\section{Allormal ligys.}

Owing to varions diseased conditions of the oriduct many difierent kinds of abnormal egge are produced by fowls. The explanation of the different types of such egos is usually tolerably clear if one gets definitely in his mind the nomal plyysiology of eger production as outlined above. We shall consiller here only some of the more important general classes of such abmormal egges. Such eggs are very interesting from the scicutific standpoint but are of relatively little practical significance to the poultry leeper becanse of the rarity of their occurrence.

Soft-shelled liggs. These are eggs laid without a sufficient amount of shell substance covering the shell membrane. The innnerliate canse lies in a failure of the uterts to function properly: Regarding this class of abmormal eggis Wright has the following to say: "Soft eggs may be cansed by lack of shellmaterial, which, if discovered, points to the remedy, the most rapid being ponnded raw oyster-shell. Or they may he cansed by the fowls being (liven or frightened, in which case they soon cease. and nothing need he done muless the injury has been so screre as to prematurely detach small and unripe yolks, when the case becomes a real abortion, or they may be caused by condiments and too much animal food, spices in particular learling frequently to all sorts of trouble with the egg-organs, particularly in the Mecliterranean races of poultry. A few small doses of Fpsom salts or jalap, and cessation of the extra stimulus, will remerly this. Put far the most ustual caluse is simple orerferling. A little careful investigation will find which is in fault, and that will indicate the appropriate remedy. Want of shell 
material is far less common than it used to le; over-feceling or over-stimulation probalily more - 0 ."

smoll. Jolkess liggs. These little exgss, varionsly called

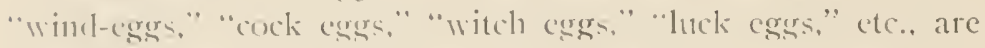
familiar to erery ponltry kecper. 'They contan no definitely formerl yolk. and to the castal observer seem to consist of nothing lut a small shell filled with white. The laying of one of the ece cess is popularly supposed to mark the enrl of a laying periurl. This belief is withent founclation in fact. They may he prolucerl at any time. Lupulblished data collected ner a period of years at this station in regarel to such egge in licate that three factors are funclamentally concerned in their prolnction. These are:-

1. The bird must be in an active laying condition; the more promonneer the alegree of plyysiological activity of the ovieluct the more likely are these eggs to be produced.

2. 'lhere must be some foreign borly, howerer minute, to scrve as the stimulus which slatl start the albumen glanls secreting. This foreign borly may lec either a minute piece of hardened allummen, a bit of coagulated bloot. a small picce of yolk which has escaped from a ruptured yolk. etc.

3. It scens likely, though this is a point not yet rlefinitely settlerl, that ovulation (i. c.. the separation of a yolk from the nvary) must precele the secretion of albumen around the forcign borly to form one of these eggs.

Double and Tripli Yolked Eggs. Egges with two yolks are. of coursc, quite common. They result from a listmilance of the time relations of nvulation, of stch nature that two yolks

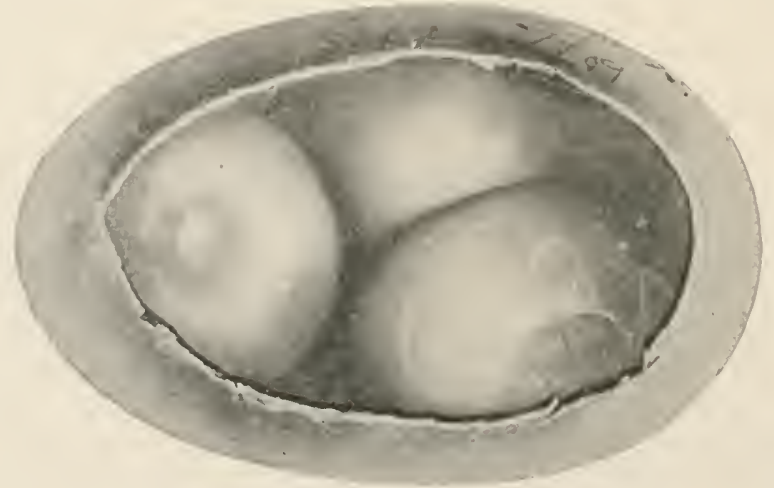

Fig. 42. Triple yolked egg. (Original). 
set into the oviduct at nearly the same time and become surromuled by common layers of albumen.

Eggs with three yolks are very rare. An egg of this kind laid by a prillet at this Station is shown in lig. 42 .

Inchusion in Eggs. The number of different foreign substances which at one time or another have been found enclosed in eggs is great. 'l'he list includes blood streaks or spots, blood ciots of frm consistency and often considerable size, lumps of bacteria, worms, fecal 111atter, etc., etc.

From the practical standpoint the only inclusions which need consideration are blood spots. Nany inquiries are an11ually received at this Station as to what canses these spots and what to do to get eggs which will be free from them. These inquiries are most frequent in the spring months. The only thing which can be done in such cases is to candle the eggs, and sell only those which show no spots. Hens which are perfectly normal often lay eges with blood spots, especially in the spring of the year when laying is heavy. The blood which makes the spot probably comes in most cases from the orarian follicle. When this ruptures a little blood escapes into the oriduct and is caught up in the albumen. The so-called "liver" or "meat" spots in eggs are in nearly every case thoroughly hardened. well packerl together, blood clots. They may be of large size. These inclusions do not represent, as they are sometimes said to, portions of the oriduct wall which have been torn off and enclosed in the egg.

Eggs of Abnormal Shape. There are many other kinds of abnormal eggs besides those here discussed, but as they have no practical significance it is not desirable to devote further space to them. In closing this section we append some figures showing in outline some of the curiously shaperl eggs which have been found.

\section{I'cut Gleet (Cloacitis).}

'This is a true venereal disease of poultry. It usuaily begins with a hen but is transmitted in copulation to the male, and by him to other birds in the flock.

Diagnosis. Salmon gives the following clear account of the symptoms: "The first symptom observed is the frequent passage of excrement which is voided in small quantities almost as rapidly as it reaches the cloaca. Oiten the birl endeavors 


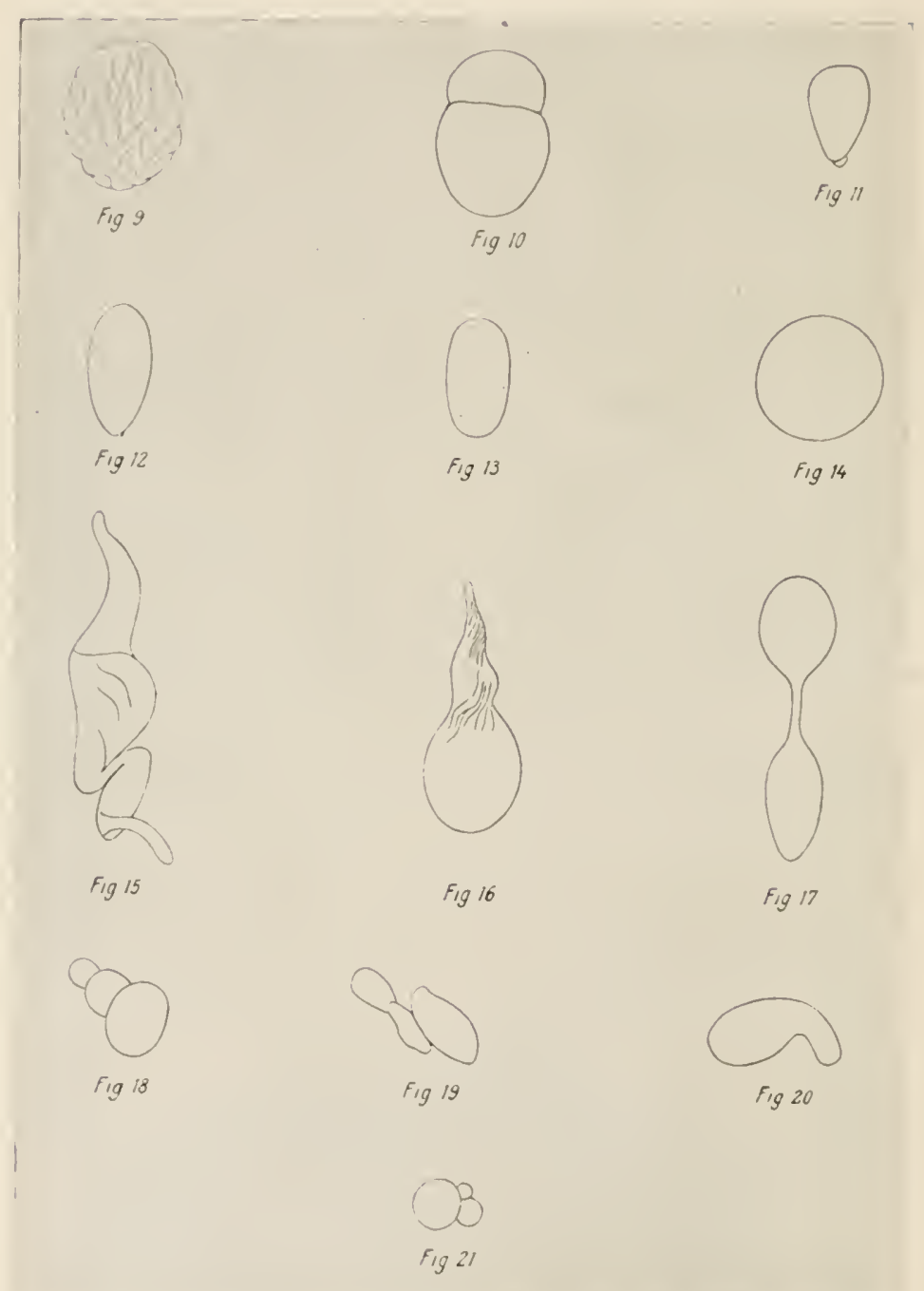

Fig. 43. Showing shapes of abnormal eggs sometimes found. (From von Durski after Landois). 
to drop excrement when cloaca is entirely empty. 'This action is dne to the tenderness and irritability of the cloaca which gives to the bird the sensation of fullness, and prodtuces spasmodic contractions. If an cxamination is made the mucons membrane is found in the early stages to be red, dry, swollen and hot. In a day or two a discharge makes its appearance. It is, at first, thin and watery, but soon becomes white, purulent, and offensive. This discharge collects upon the skin and feathers about the vent, obstructs the passage and irritates the parts with which it comes in contact. The soiled skin becomes red and inflamed, it may be abraded by friction or by the bird picking at it, and thus sores or ulcers are started which may become quite troublesome."

Etiology. The cause of the disease has not yet been thoroughly worked out. Wright suspected it to be identical with human gonorrhea because of the similarity of symptoms, infectiousness, etc. However, he has not been able to isolate the Gonococcus, or specific germ of gonorrhea from affected birds.

Treatment. The following is the treatment outlined by Vright: "Any hen found with it should at once be isolated. and the male bird carefully cxamined, and if necessary also isolated. Give 30 grains Epsom salts, and twice a day inject first a 4 per cent solution of cocaine, and immediately afterwards a solution of nitrate of silver 4 grains to the ounce. The fifth day commence a small copaiba capsule daily, and inject acetate of lead, I drachm to the pint. Feed rather low meanwhile, and dust any sore places ontside with iodoform or aristol. If not well after 2 or 3 weeks, we would kill the bird, as the disease is not quite free from danger; for if the operator should touch his eyes accidentally before he has cleansed his hands, the result might be a most violent inflammation."

\section{"Break Doren."}

Sanborn (Farm Poultry Doctor) gives an account of this trouble, which, while brief, is to the point, and says all that really needs to be said about the matter. Especially to be commended is the last sentence.

"This is the 'baggy condition' often seen in old hens that have had too much corn. The rear part of the abdomen is crowded with fat and hangs down, sometimes to the ground, giving a very unhandsome appearance to the bird. The ceasing to feed corn 
and other fat-producing fools will sometimes remerly this condition, hut a lircl that has been allowed to get into such a shape is spoiled for life both as a layer and breeder. The hatchet and pot should be the fate of such a bird."

\section{Discuses of the Male Reproductice Organs.}

A number of discases of the male reproductive organs have been described but they are all of $n 0$ practical significance, for the reason that no poultryman ought erer to use as a breeder a male bird that ever had any disease of these organs, whether it had been "cured" or not. 


\section{CHAP'TER NIX.}

\section{Diseases of Chickens.}

\section{White Diarrhea.}

Of all the diseases which the poultryman is called upon to fight, there is probably none so destructive, year after year, as the disease (or diseases) known as "white diarrhea." The loss of chicks ascribed to this cause varies in different years and is different places from ro to 90 per cent. It is perlaps not too munch to say that more than 50 per cent of the chicks hatched thronghout the country are lost from white diarrhea in its various forms. The number of inquiries concerning this disease which are annually received, and the amount of space deroted to it by the poultry press, lead one to believe that "white diarrhea" is perhaps the worst enemy with which the ponltryman must contend.

White diarrhea is more common among artificially hatched and brooded chicks than among those which have been hatched ancl cared for by hens. However, it is by no means unknown among the latter. Many poultrymen report as heavy mortality from this disease among hen hatched and reared chicks as from those which were incubated and brooded by artificial methods.

Almost any chick that comes ont of the shell apparently liealthy on the 2 Ist day will live for the first week. If white drarrliea is going to strike the brood they usually begin to show symptons abont the end of the first week or later. 'The heary loss of clicks from this disease occurs between the ages of $\mathrm{I}$ and 3 weeks. Where the brood is badly affected chicks may continne to die mutil the fourth or fiftl week. On the other land if a brood gaes throngh its first 3 weeks of life withont being attacked by this clisease it is practically safe from its ravages. White diarrhea then may be said to be linited to the first 3 weeks of the chick's life so far as serions mortality from it is concerned. The reason for this no doubt is that the digestive 
system of chicks under 3 weeks old is so delicate that eren a slight disturbance makes a very serious handicap for the chick.

Eitiolog!. I Ithin recent years a large number of studies concerning the cause, prevention and cure of white diarrhea lave been conducted. Investigations have been carried on by state and national institutions as well as by many private indrviduals. Consequently a large number of alleged eauses of the disease are given by different writers. Among these may bc mentioned: Debilitated breeding stock, improper incubation, improper brooding, overheating, chilling, poor ventilation, over-crowding, poor or improper food and filth as well as specific bacteria. fungi or other parasitic organisms.

Dr. Geo. B. Morse in the Reliable Poultry Journal for July, 1909. classifies the causes of diarrhea in chicks as follows:

"First among these causes is the class of physical agents. Under this title I would place such agencies as heat or its lack, moisture or its lack. producing what we call in human medicine, the diarrhea of relaxation. Such a condition is produced in the intestinal tract that a large amount of serum is driven through the intestinal wall into the lumen of the intestine, and in doing so the cells are loosened, and thus we have the development of a catarrh. This condition may be brought about by the agencies just mentioned."

"Another class of agencies may be designated foreign bodies. and in this class I place such diarrheas as originate from improper fecding, too early fecding or feeding wrong material. We know, from analogy, that in mammalians whether human or the lower animals, such a condition is possible."

"Then we have another large class of intestinal derangements c1 catarths or inflammatory conditions produced by what we call living agents or parasites. These produce what we may call parasitic inflammations. Now, we must subdivicle this class into two, and we may get rid of one substance at once by placing in it those catarrhs or inflammations produced by the larger parasites, macroscopic parasites, such as worms."

"Thus we come to the other sub-class of parasites causing derangements in the intestines, the microscopic parasites or microorganisms. This sub-class of diarrhoea-producing micro-organisms falls naturally into 3 groups. Haring already referred to the animal kingdom in speaking of worms we shall take our first group of parasitic micro-organisms from that same king- 
dom; these are the protozoa, the lowest animal forms. 'The other two gromps of micro-organismal agents of enteritis are found in the plant kingdom; they are bacteria and molds. Hence, the 3 groups of microscopic agents of intestinal inflammation are protozoa, molds and bacteria."

It is doubt ful if many of the cases of true white diarhea are caused by the physical or mechanical agents mentioned in Dr. Morse's first two classes. In most cases true white diarrhea appears to be an infections disease. Such disease we know is caused by some form of parasitic organism. Without doubt improper incubation, brooding and feeding, resulting in weakened chicks, rery often lay the foundation for the attacks of parasitic organisms. In many cases these fanlty methods of handling the eggs and chicks appear to be the real canse of the disease while they are really only indirect causes.

From this it should not be understood that such things as poor food. poor brooding and weakened breeding stock are of 110 importance in the study of white diarrhea. It is just exactly these predisposing factors which result in chicks with weak constitutions, easily overcome by discase germs. Without doubt the points at which most progress can be made in combatting such diseases are in the methods of incubation and in the care of the chicks for the first 3 weeks of their lives. Nevertheless ii should not be forgotten that the death of the chick is cattsed by the ravages of some minute parasitic organism.

Within recent years several investigators have discovered organisns which they believe to be the specific canse of white diarrhea. 'Three of these may be mentioned at this place: (1) Coccidium toncllum or cuniculi producing the disease called "cuccicliosis." (2) Bactcrium pullormm producing "bactillary white diarrhea" and (3) Aspergillus fumigatus and allied species, producing aspergillosis or brooder puemmonia of chicks. Of these the first two diseases will be considered in some detai! in the following paragraphs. Aspergillosis is treated in a separate section of this chapter (cf. p. I93).

\section{Intestinal Coccidiosis.}

In Circular 128 of the Bureau of Animal Industry, U. S. Department of Agriculture. Dr. G. B. Morse published a preliminary acconnt of some investigations on the canse of white cliarrhea. Microscopic examination of the intestines of clicks lying 


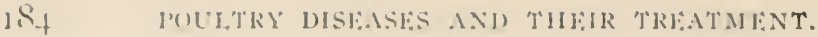

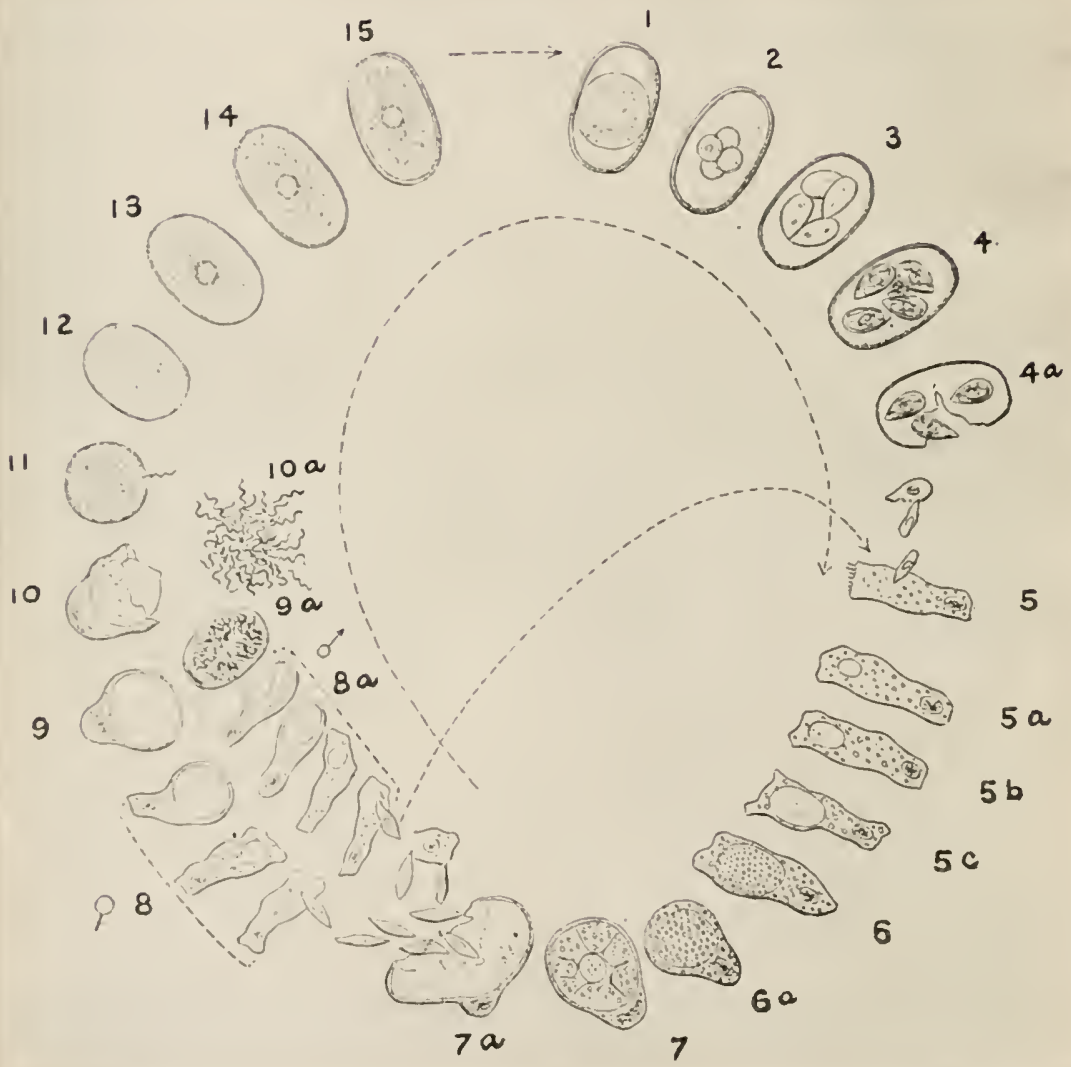

Fig. 44. Diagrammatic representation of the life history of a Coccidium. (After Cole and Hadley). 
with this disease revealed the presence of large numbers of protozoan organisms which he identified as Coccidium tencllum. At practically the same time Drs. Cole and ITadley of the Rhode Island Experiment Station reported finding a sinilar organism in white diarthea chicks. They identified it as Coccidium cuniculi. 'These two species of coccidium are so nearly alike that it is very difficult to distinguish them except ly prolonged study of their life cycles. Varions species of coccidia have long heen known to infest many domestic animals. In all cases that have been studied they produce very serious diseases.

The life listory of a coccidium is very complicaterl yet in order to combat this parasite most successfully it is necessary to know something of its life history. Fig. 44 represents the different stages in the life history of these parasites. If one shonld examine with a microscope the contents of one of the ceca of a chick which died with this form of white diarrlea he would find forms somewliat like No. I in the figure. 'These are the oöcysts or permanent eysts of the coccidimm. The membrane aromd the nutside of this eyst is very tough and will withstand almost all methods of disinfection. It will live and even grow in sulphuric acil. It can be killed, however, by drying. The size of these cysts is about $14-25000$ inch and $21-25000$ inch. If this cyst is placed muder the right conditions for development the first step is for the protoplasm to divide into 4 spherical bodies which are called sporoblasts (fig. 44, 2). Fach of these sporobiasts then divide into two sickle-shaped sporozoids (cf. fig. 44. 3 and 4 ). 'These sporozoids are then set free in the intestinat tract ( $\mathrm{fa}$ ) and each one penetrates with its pointed enil an epithelial cell of the intestine as at No. 5. In the figure 5a, 5b, 5c, 6 and 6 a. represent the succeeding stages of growth of the organism within the intestinal cell. As shown in 6a and 7 the parasite grows so large that it completely fills the cell and finally these eclls are broken down and torn off the intestinal wall. The stage of the parasite shown at 6 a and 7 is known as the schizont. 'The next step is for the schizont to loreak nip into a larger number of sharp pointed borlies as shown at 7 a. These escape and enter other epithelial cells just as the somewhat similar hodies did at 5. At this point the organism may do one of two things. The small sporozoids from za may develop exactly like the sporozoids did from 5 to 7 . 'This part of the life' 
crele, as shown by the shorter arrow from 7 a to 5 may be repeated any number of times.

li. however, the conditions are not very good, i. $c$., the bird is about to die the sporozoids undergo an entirely different development as shown at numbers 7 to 15 (fig. 4.7 ). Here the sporozoids enter the epithelial cells and some (levelop into very large (egg) cells (female element) as shown at 8.9 and 10. Others go through the development shown in Sa, 9a and roa, forming a very large number of minute motile zooids or sperms (male (denent) which unite with one or more of the large egg cells as shown at 11 . After this sexual union there is developed the öncyst like No. I, with which we started. At all stages of this clisease many of these cysts are carried to the ontside with the feces and upon being picked up serve to infect other chicks. 1)eath is carsed by the parasite attacking so many of the intestinal cells that the chick is no longer able to digest its food. There are also secondary effects by which the kidneys are derangerl and throw out a large amount of white urates, hence the name "white diarrhea."

Diagnosis. The symptoms of coccicliosis are similar to those of other forms of white diarrhea. (cf. p. IS9). The only exception is that according to Morse the ceca are always distended with yellowish-white cheesy matter. In other forms of white diarrhea this may or may not be the case. These different forms of white diarrhea have been too little studied yet to permit of an exact differential diagnosis on external symptoms even supposing that ever to be possible. With the aid of a microscope the finding of coccidial cysts in the fecal matter 110ukl indicate that these were causing the disease.

Dr. Hadley has carried out some feeding experiments with these cocciclia and has found that he is able to produce the disease in chicks more than two days old. As will be mentioned later (p. 188) it is said that infection with the bacterium of bacillary white liarrhea cannot take place after the chick is 48 hours old. It is possible that further work will show that these facts are of some importance in distinguiching these two forms of the rlisease.

\section{Bacillary Whitc Diarrhca.}

In May, igo8, Dr. L. F. Rettger and Mr. S. C. Harvey published a paper on "Fatal Septicemia in Young Chickens or 
"White Diarrhea," (Journ. Med. Research). From a large number of observations and experiments they came to the conclusion that white diarrhea was caused by a bacterium. A number of later papers by Dr. Rettger have appeared since then (c. g.. Journ. Med. Research, July, 1909; Am. Ponlt. World. Vol. T. Nos. 3 and 5; also Rettger and Stoncburn, Storrs Agr. Expt. Sta. Pul. 60). In all of these the fact has been clearly brought out that at least one form of white diarrhea is cansed by a bacterium.

Dr. Rettger took chicks which had died with all the symptoms of white diarrhea and by the ordinary bacteriological methods obtained pure cultures of a bacterium which had certain definite reactions and habits of growth. By these methods this bacterium can be distinguished from other kinds. To this species of bacteria he gives the name Bacterium pullorum. Now if entirely healthy chicks were inoculated with the pure culture of this bacterium they almost invariably showed symptoms of white diarrhea and in many cases dierl. To cite only one case; at the Storrs Experiment Station (Bull. 60) 210 IVhite Leghorn chicks were hatched from healthy stock. These were divided into several lots, some of which were infected by fceding boutllon cultures of Bacterium pullorum. Other lots were used as controls. The results were as follows: "During" the first two weeks the comparative mortality was as follows:

Control lots ( $8+$ chicks) 5 deaths or 6 per cent.

Infected lots ( 126 chicks) 22 deaths or i 8 per cent.

At this time the chicks in the control lots averaged is per cent more in weight than those in the infected lots and appear in cvery way greatly superior to them."

In many cases Dr. Rettger was able to find Bacterium pullorum pure in the artificially infected bircls. Further he was able to obtain the same bacterium from a large number of different chicks gathered from widely different localities. Dr. Rettger says (Am. Poult. World, January, 1910): "From the blood of the liver, heart and lungs I have repeatedly found the organisn-Bacterium pullorum. More recently I have been able to obtain the organism without difficulty, from the unabsorbed yolk and in some instances from the crop of the affected chicks. In some chicks that were quite young at the time of death (2 or 3 (lays) the same bacterium may be fotmel in the 
intestines. In olfler birds it is obscured by the common and rapilly growing intestinal organisms, particularly the colon bacilli1s."

Dr. Rettger has also been able to find this same organism "in (a) the ova in the ovaries of the hens, (b) the yolk of fresh laid eggs. (c) eggs incubated for varying lengths of time and (d) yolk sacs of fully developed chicks still within the shell." This, together with the evidence that the organism does produce white diarrhea, shows pretty conchusively that one source of infection is the hen. The feeding experiments with pure cultures of the bacillus apparently show that the infection must begin within the first $4 S$ hours after the chicks are hatched. Several investigators have shown that it is impossible to infect chicks by feeding after they are two days old. It may be said that Dr. Rettger has proven that at least one form of white diarrhea is caused by a lacterium. 'The relation of this form of the disease to that caused by other organisms is still a subject for investigation.

Diagnosis. The external symptoms of bacillary white diarthea are much the same as those given for the disease in general (cf. p. I $8 g$ ). The following post-mortem appearances are reported by Rettger and Stoneburn:-

"Crops-Empty or partially filled with slimy fluid or with foorl."

"Lumgs-Apparently normal. ('Tubercles not observed)."

"Liver-Pale, with streaks and patches of red. These apparently slightly congested areas are usually large in size."

"Kidney and Spleen-Apparently normal."

"Intestines-Pale, and for the greater part empty. A small amount of dark grayish or brownish matter frequently present."

"Ceca-With few exceptions but partially fillerl with a grayish soft material. Only occasionally cheesy or firm contents."

"Unabsorlsed lolk-Ustally present varying in size from a pea to a full-sizerl yolk. The color may vary from yellow to brownish green or nearly black. In consistency there is also much variation. It may appear perfectly normal, distinctly selatinons, or watery. Frequently it is observed in the character of custard and again more or less dry and firm. Unless the click has been dearl for some time the yolk is usually not found putivi, but merely stale." 
"The chick as a whole appears more or less anaenic and emaciated. 'The muscles of the wings, breast and legs may be almost completely wasted away."

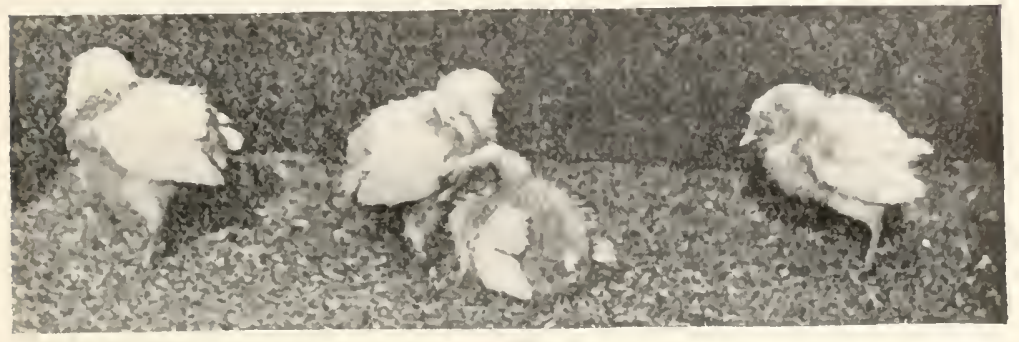

Fig. 45. Ten day White Leghorn chicks showing symptoms of bacillary white diarrhea. (After Rettger and Stoneburn).

The chicf difference between this and coccidiosis appears to be in the contents of the ceca (cf. p. 186).

Diagnosis of White Diarrhea in General. The symptoms of white diarrhea are in general the same for the different forms of the disease. They may be briefly stated as follows: The affected chicks appear stupid and remain under the hover or hen much of the time. They isolate themselves from the rest of the flock and appear indifferent to what goes on about then. Their feathers become rough and the wings droop (cf. fig. 45). There is progressive loss of weight. The birds eat little or

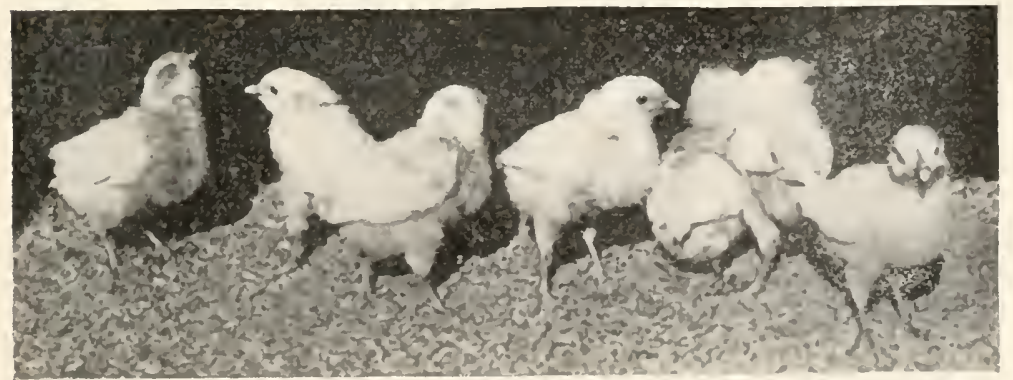

Fig. 46. Normal ten day White Leghon chicks. (After Rettger and Stoneburn).

nothing and appear unable to pick up their food. Their actions in this direction are chiefly mechanical. The characteristic whitish discharge from the vent very soon makes its appearance. The discharged matter may be creamy or sometimes 
nnixel with brown. The discharged matter is nore or less sticky or glairy. In many cases it clings to the down in sufficient quantity to phug up the vent. This conclition is known as "pasting up behind."

Many of the chicks chirp or peep constantly or will utter a shrill cry apparently of pain, when attempting to void the excreta. These sounds are often characteristic of the disease.

In many cases the chicks present the appearance of being "short backed" or "big bellict." Dr. Woots rleseribes this as follows:

"The weakling is almost always big-bellied, the abdomen prounding to the rear so that it bunches out behind, well out of line with the vent, with the result that the chick looks as if the tail piece and backbone has been pushed forward and in just above the rent." (Cf. fig. 45).

In some cases the chicks die with but little warning and show few of the above symptoms. In other cases the sick chick will last a long time showing all the symptoms mentioned.

Post-mortem examination often reveals but few lesions. One of the most striking things is the loss of flesh if the disease has lasted for some time. The alimentary canal is usually nearly empty except for some slimy fluid. The organs are all very palc. The liver may have a few streaks showing congested areas. Some of the unabsorbed yolk nay or may not be prescnt. There is considerable variation in its appearance. It is not usually putrid unless the chick has becn dead for some time.

The ceca are often filled with firm, cheesy or soft grayish material depending apparently to some extent upon the form of the disease (cf. pp. IS6 and I88).

Treatment. The treatment of white diarrhea depends somewhat on the cause. If it is due to improper feeding or brooding of course the only treatment consists in removing the cause. This will prevent the trouble in the later flocks and will help those already affected. A small dose of a goorl purgative such as Epsom salts will probably help in bringing the chicks into better condition. Dr. P. T. Woods recommends giving the chicks scalded sweet milk with a little grated nutmeg 4 times a dlay. He also recommends boiled rice as food. They should have plenty of charcoal before them and in their mash. They should also have green food every day. If green food is not available raw vegetables may be substituted. Some good anti- 
scptic slould be used in the drinking water. Potassium permanganate as recommended on p. I6 may be used. Dr. Morse recommends al bicluloride of mercury, using IO of the $1-1000$ grain tablets to one quart of water. Also 10 grains of iron sulphate to the gallon of water is said by some to be good. It is the opinion of the writers that neither of the latter two is as desirable for use as an antiseptic for the water as permanganate.

These recommendations apply to any case of white diarrhca whatever its cause. In the forms of white diarrhea caused by parasitic organisms specific modes of treatment or of prevention may be recommended. In the case of coccidiosis Dr. Morse says that the eggs should be dipped in 95 per cent alcohol or a 4 per cent solution of a good coal tar disinfectant before they are placed in the incubator. The incubators and brooders shonld all be thoroughly disinfected every time they are used. The treatment of sick chicks should be as recommended above.

In the case of bacillary white diarthea the same recommenclations for disinfection of incubators, brooders and the premises should be followed. Dr. Rettger says that it is only cluring the first 48 hours that the chick can be infected. Consequently the very greatest care should be taken during those first two critical days. However, the fact that the bacterium has been found in the yolk of the unhatched-even of the unlaid egg-indicates very clearly that something more than disinfection is necessary to stamp out the disease. Very great care should be exercised in picking ont breeding stock. It is very likely that the hens which lay the eggs infected with the bacteria were chicks which recovered from white diarrhea. The bacteria still continue to live over in their bodies. Every effort should be marle to locate and remove the source of infection. If there is widespread infection on the farm, eggs for hatching should be obtained from other places where there is little or no white diarrhea.

On methods of preventing and eliminating bacillary white diarrhea Rettger and Stoncburn give the following.

"If the disease makes its appearance among the flocks of chicks every effort should be made to ascertain the source of the infection. This may be (a) breeding stock upon the place. (b) eggs for hatching secured from other breeders, or (c) newly hatched clicks purchased from others." 
"If the breeding stock proves infected there are two courses of procelure open; (a) market the entire flock or refrain from using their eggs for hatehing. or (b) install trap nests in the breeding pens and by means of accurate pedigree records ascertain which individual hens are producing infecterl chicks, and remove such hens from the breeding flock."

"Since infection may be brought upon the place through purchaserl eggrs or stock, such purchases should be made from farms where bacillary white diarrhea is not common."

"If bacillary white diarrhea is known to be present on the place steps should be taken to prevent the spread of the infectiou, and, if possible, to effect a cure. (As to the latter we do not feel justified in offering any suggestions at this time)."

"Preicution. Since the disease cannot, apparently, be transmitted through the food supply after the chicks have reached the age of 3 or 4 days, every means should be pursued to prevent the spread of the infection during this critical period. IVe suggest :

The segregation of the chicks in small lots during this interval.

Ferfect disinfection and cleanliness of brooclers and brooder coops.

Food and water supplied in such a manner as to prevent contamination by the droppings."

"The use in the brooder of a liberal amount of fine, absorptive litter which will quickly cover and seal up the droppings."*

"Raise and maintain the vigor and vitality of the breeding stock and chicks by every reasonable means known to the poultryman."

\section{L.cg Wcakncss.}

The term "leg weakness" is sometines used by poultrymen to inclicate the lameness fue to rheumatism in aduit birds. Regarding this form of the disease see p. 123. The more usual use of the term "leg weakness" is to denote a disease or ailment which is found in growing chicks, from I month to 6 months of age. It is said to be more common among cockerels than pullets and is more frequent in the heavier than the lighter breeds. The chicf cause of the trouble seems to be that in birds growing rapilly and fed heavily the weight sometimes increases faster

\footnotetext{
*For this purpose we have used alfalfa meal with much satisfaction.
} 
than the strength. 'This results in a weak knecd, wobbling bird. The discase is sometimes ascribed to other causes such as overcrowding.. close, muentilated quarters, overheating, etc. Salmon says "It may develop in young chickens kept in lrooders in which the heat is not properly distributed or where there is too much bottom heat, also in those which are kept constantly upon wooden Hoors." Regarding these cases Robinson says "Where such conditions are present the leg weakness is more likely to be an aceompaniment of diseases which plannly show other symptolns."

Diagnosis. The symptoms are indicated in the name of the discase. It first appears as an mnsteadiness in the walk. This may gradually become worse until the bird is unable to stand alone and is constantly tumbling over. The birds are found sitting while eating and are inclined to walk very little. When the trouble first appears there is little else wrong with the bird. The eye and comb are bright and healthy, the appetite is good. Later, however, the bird being weaker than the others gets less grain and becomes thin, feathers out poorly and is a distressed object. It is said that rhemmatism can be distinguished from leg weakness by the swelling of the joints in the former disease.

Tratment. This consists chiefly, of course, in removing the cause. Since the most common cause is the overfeeding with fat producing foods, the amount of these should be reduced. The weak birds should be removed to a pen by themselves. Substitute bran, wheat and oatmeal for the corn and corn meal. Give skim milk, if possible, instead of water. Fecd plenty of green food. This is one of the most important measures. Sanborn recommends rubling the legs with tincture of arnica and arlcling $1 / 2$ teaspoonful of tincture of nux vomica to each quart of drinking water.

\section{Aspergillosis or Pncumomycosis.}

This disease, which is discussed on p. 1 , not only occurs in hens but it is also a very common and fatal disease in young chicks. It often occurs with white diarrhea and the double disease was for a long time consilered as one. Poultrymen designated the cases in which the lesions occurrerl in the lungs as "lungers." Investigation has shown that there are two diseases which may occur separately or together. 
Diannosis. 'This disease is characterized by a dumpish steepy' condition of the chick. The wings are pendulent. Pireathing is rapjicl and sometimes accompanied by snoring somuch. A whitish diarrhea is present. A lifferential diagnosis between this and the cocciclial white diarrhea is only possible by an exanination of the dead birds. In aspergillosis, yellowish tubercles which closely resemble those of tuberculosis occur in the lungs and in the walls of the air sacs and often also in the intestines, mesentery, liver and other organs. In very acute cases the lungs are simply inflamed, death occurring before the formation of the tubercles. The mycelium and spores of the fungus may be found by microscopic examination of the tubercles and this fungus may be obtained by inoculating cultures from these tubercles.

Etiology. The disease is caused by the spores of an Aspergillus usually A. fumigatus, fig. 22. This is a very common fungus and the spores are widely distributed in nature. The spores are often fomnd on the food or on the litter and are inhaled or taken in with the food. Incubator chickens are often infected from the incubators and brooders and hen hatched chickens from the straw or chaff in the nests. Sometimes the chicks get the disease from chick food not properly cared for. It is possible that this disease as well as the coccidial and bacillary white diarrhea is sometimes carried in the egg. The spores and mycelium are often found in the digestive tract of hens and it is not unlikely that they may work up the oviduct from the cloaca and infect an egg before it gets its shell.

Tratment. The treatment of diseased chicks is useless. When they are infected the spores develop on the membranes and new spores are formed which spread the infection throughout the respiratory system and also to the other organs. The only effective treatment is prevention. Keeping the flock muler goorl hygienic conditions with clean food, litter and nesting material reluces the chance of infection and keeps the chicks in a vigorous condition in which they are able to resist the disease. The dead chicks should be burned or buried.

Prognosis. The lisease is fatal so far as known.

\section{Eimphy'sema.}

This name is applied by Robinson to a disease of young chicks in which the skin puffs out in the sides of the neck near its 
juncture with the body. 'lle size of the puff varies somewhat. In mild cases it is about the size of a hickory nut. Sometimes there is one puff. sometimes several. A few cases have been reported "where the puffing covers nearly the whole boly, the skin of the chick being so inflated that locomotion becomes difficult." (Robinson).

Accorling to Vale the trouble generally occurs in growing chicks which have been confined in close quarters. It is often associated with some lung trouble. It seems to be due to obstruction of the air passages and the rupture of some of the air sacs. The air thus escapes into the tissues beneath the skin. While not common this disease does oceur in Maine. Some cases were reported to the Station while this work was in preparation.

'The treatment suggested by Vale is to puncture the skin with a needle and to give 2 grains nitrate of iron to each wine glassful of lrinking water. Robinson, however, says: "It is rather to be recommended that no effort be made to treat such chicks. Even if cured of the trouble, they rarely develop satisfactorily."

\section{Gapes.}

Gapes is a disease which attacks domestic ponltry and many species of wild birds. In fowls it is more frequently observed in young chicks. It occurs also in adult fowls but rarely causes enough inconvenience to attract attention. The disease is due to the presence of minute parasitic worms in the air passages.

Diagnosis. "'The symptoms of gapes are frequent gaping. sneezing, a whistling cough with discharge of mucus and worms. dumpishness, weakness and drooping wings. When badly affected, the bird shakes its head frequently, gapes and coughs as if suffocating, droops and is not able to keep up with the rest of the flock, and stands in "dumpish" position with eyes closed. wings drooperl, mouth open and tongue protruding." (IVoods. Rel. Poult. Rem.)

The correctness of a diagnosis for gapes should be tested by determining whether or not the worms are present in the trachea. When chicks are dying from a disease supposed to be gapes the trachea of a dead bird may be examined. If the trouble is gapes the worms will be found attached in pairs to the mucous membrane of the trachea. 


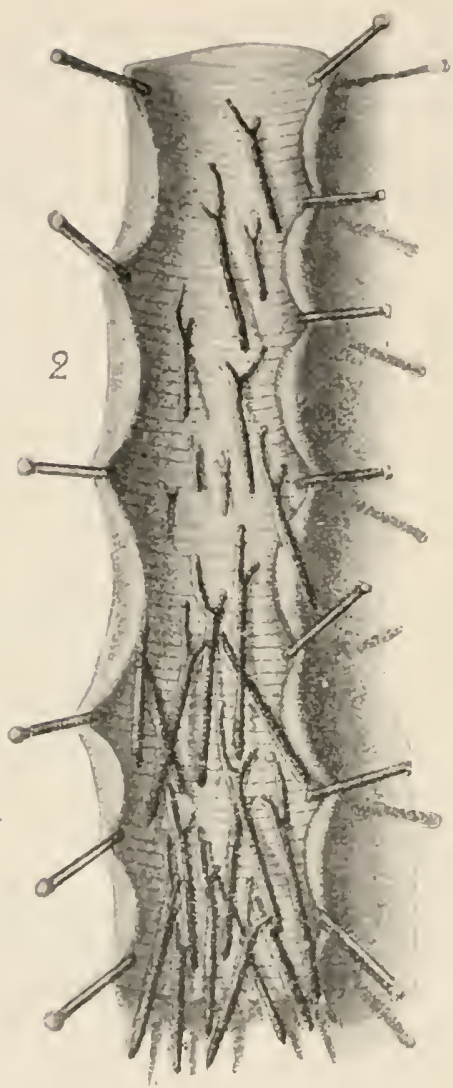

Fig. 47. Trachea (windpipe) of

a pheasant showing gape worms (Syngamus trachicalis) attached to the mucous membrane. (After Megnin).

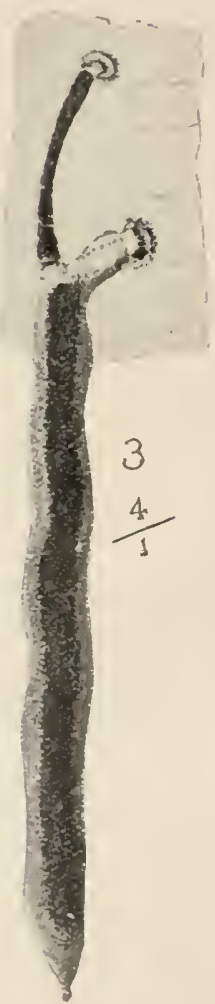

Fig. 48. A pair of Syngamus trachealis, a $\mathrm{t} \mathrm{t}$ a $\mathrm{chc}$.

(After Megnin).

The two sexes are joined together in such a way that a pair looks like a clouble headed worm. The female is about $1 / 2$ inch long and the ma?c about $\mathrm{I}-5$ inch. The worms are pale in color when empty but when they have been feeding they are red with the blood of the chick. The presence of the worms in the trachea of a living chick may be demonstrated by passing a gape worm extractor (a loop of horse hair or fine wire or a feather with the vane removed except at the tip) carefully down the trachea for some distance turning it around to loosen the worms and drawing it out. If the worms are present some will be removerl with the extractor. 


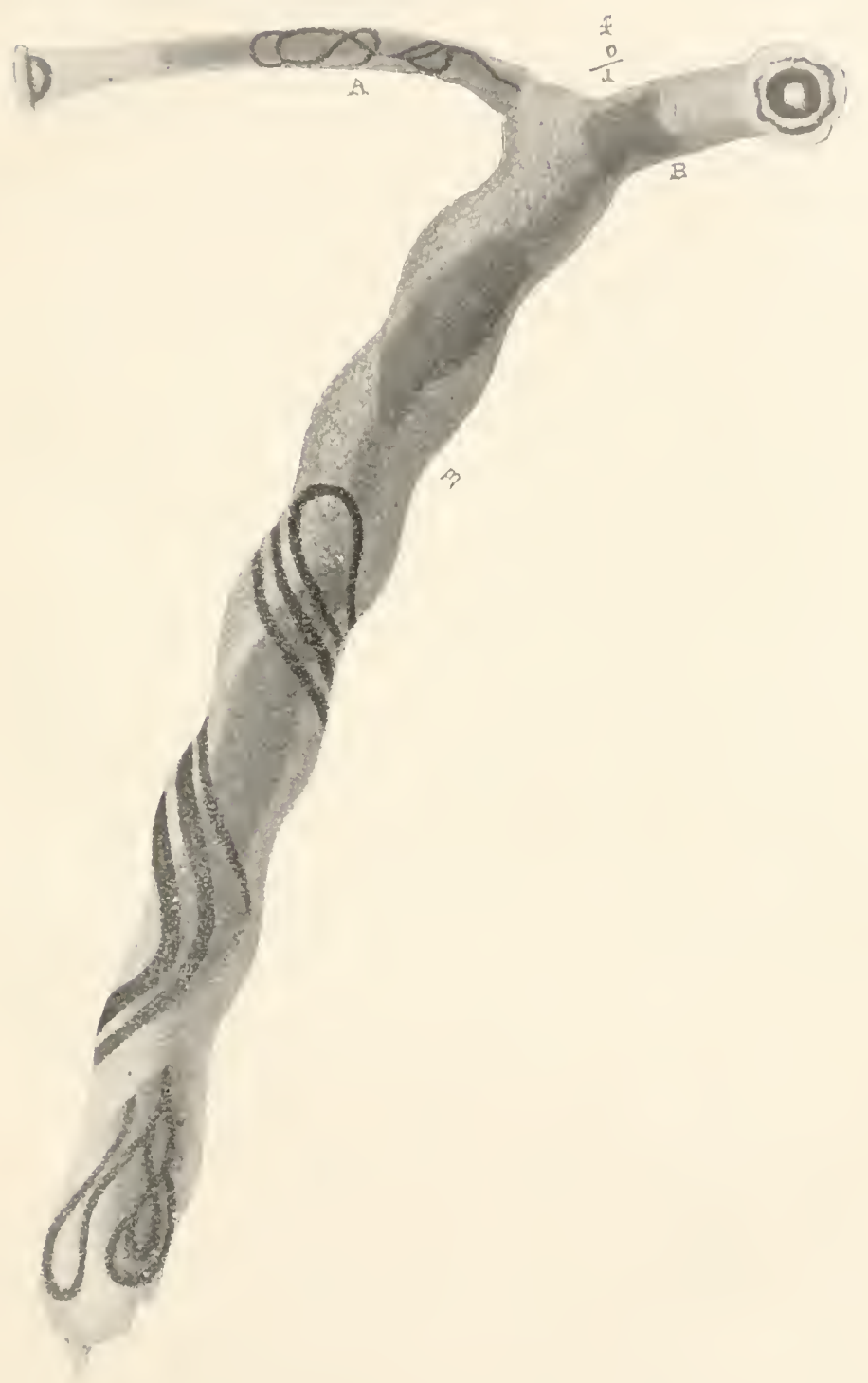

Fig. 9 . A pair of Syngamus trachalis. 1, mále. B. female. (After Megnin). 
The presence of the worms cattses an irritation and inflammation of the membrane and stimulates the secretion of mucus. Some of the accmumulation of worms and mucus is expelled by conghing. Sometimes part of it is swallowed and expelled with the feces. The loosened material may be drawn into the deeper air passages during inspiration. Death may oceur from suffocation due to the obstruction of the air passages with worms and mucus, or weak individuals may die from loss of blood.

Eitiology. The only cause of the disease is the nematode or thread worm Syngamus trachcalis Siebold, called the gape worm, red worm, or forked worm. (See figs. 47 to 49 ). 'These parasites obtain their nourishment by sucking the blood from the mucons membrane of the trachea. They are attached in pairs to the membrane by their sucker-like mouths. Peside bringing about a considerable loss of blood the worms cause irritation and inflarmation of the membrane and a copions secretion of mucus. The two sexes are so closely attached to each other that they can not be separated without tearing. The body of an adult female is swollen with thousands of eggs and occasionally contains some cmbryos. The eggs are not laid but escape when the body of the female is ruptured. This may take place with the (lecomposition of the worm or the borly may be torn by the conghing of the bird. The eggs may develop and grow to adlult worms within the trachea of the same bircl. The worms. eggs and embryos are often coughed up). Sometimes they are swallowed and then some of the eggs and embryos may be passed with the feces. The worms conghed up are eagerly eaten by the same or other bircls and the ova and embryos are often taken with contaninated food and drink. Developing embryos have been found in earth worms living in infected poultry yards, and these will cause gapes if fed to chicks.

The eggs and embryos need only wamth and moisture to develop. Eoggs may develop in the digestive organs. It is not known how the embryos reach the trachea from the digestive organs. A large number of those eaten never reach the trachea but are either digested or voided with the feces. Salmon says: "Although there are some thousands of eggs in the arlult worms, to to is worms have been fed to a single chicken, and, as a result. not over + or 5 embryos wonld reach and develop in the trachea." Accorling to Theobald, Ehler found copulated worms where several of the females were full of worms io days 
after feerling ova to healthy chicks. WVet clay soils are especially favorable to the gape worms, and they thrive best in warm, wet weather.

Tratment. In eradicating the disease it is important to isolate all affected birds so that the worms and ova coughed up or roirled with the excrement may not be eaten by the other chicks or contaninate the food, drink, and the ground of the runs. linn the bodies or at least the heads and necks of all rlead birds. The feed troughs and water dishes should be scalded and the honses, and coops disinfected. Use potassium permanganate in the rlinking water. If possible provide fresh runs on which there has been no poultry for several years. The following paragraph from Robinson is much to the point:

"I'reventive treatment to be fully effective, scems to require that fowls be kept away from infected gromul for sereral seasons. It is saicl that ground from which poultry is kept for three years. the land meanwhile being sown to grass or cultivated, will be entirely free from the gape worm. To a pottltry kecper whose area of land is small this means moving or keeping no poultry for several years. Where land is abundant gape worms can often be avoicled by moving the ponltry to a plot not recently occupied by them. Treatment to disinfect the snil by destroying the gape worms in it. the object being to continue the poultry on it. is not often profitable."

The following methods have been recommended for disinfecting the ground. It is doubtful if these are economically arlyisable.

Treating the ground with air slaked lime and sparling.

Sprinkling with one of the following solutions:

I per cent or 2 per cent sulphuric acisl.

2 ounces of copperas dissolverl in a pail of water.

$1 / 2$ ounce of crystals of potassium permanganate to a barrel of water.

The lime or acisl treatments are most often recommeneled. The infected hircls should be kept in honses easily cleaned and disinfected and this should be done frequently to prevent reinfection of the recovering birds. Theolatel advises an addition of 3 drams of salicylate of soda to each quart of drinking water to destroy egres and embryos that may contaminate it.

The individual surgical method may be profitably practiced in sone cases. It seems to be the only sure methorl ret arl- 
vised of rilding an infested bird of the parasites. II right gives the following description of the methorl:

"The old-fashioned cure was to strip) a small quill-feather, all but a small tuft at the point, and (moistening it in turpentine or not) introluce it into the trachea, turn it round, and withdraw it with the worms. This is effectual, but requires care to prevent lacerating the wind-pipe or causing suffocation. In this way 30 worms have been successfully extracted from one chicken. A very much better method is to take two straight hairs from a horse's tail, laid together. tie a knot on the end of the pair, and cut off the ends close to the knot. 'This is passed straight (i. e., withont twisting) down the windpipe as far as it will go without bending, then twisted between the finger and thumb and drawn ont. A trial or two may miss, but usually 5 or 6 attempts will bring mp + or 5 worms, and the hairs inserted in this way, withont twisting, do not seem to hurt the chicks, and are used with the greatest facility. The bringing up of even from + to Io worms, and the failure of more to come after a lilank trial or two, may usually be reckoned as a cure."

IIre gape worm extractors may be bought from dealers in poultry supplies, or one can make one for himself by taking No. 30 wire, forming a loop at one end just big enough to go easily down the trachea, and then twisting together the ends of the wre to form a long handle. Norms remover should be burned.

Prognosis. This disease is often fatal in young chicks from one to four weeks old, especially in small weak birds. Young chichs and in most adult fowls it often causes little inconvenience. These fowls, however, are constant sources of infection. The removal of the worms from the trachea if skilfully done so that the delicate membrane is not injured usually effects a cure but this individual treatment requires considerable time and the value of the chicks must determine whether or not it is cconomically profitable. 


\section{CHAP'TER XX.}

\section{Poultry Surgery.}

It is proposed to consider in this section those pathological conditions of poultry which demand surgical traatment tor their cure. At the outstart it should be said linat poultry bear and recorer from surgical operations very well. The common practice of caponizing, usually done without any aseptic precaution whatever and with small losses from infection, is sufficient evidence of this. Probably no manmal would bear opening the abclominal cavity (which is done is every caponizing operation) with such entire and nearly uniform freedom from ill effects as attends this operation with poultry. The reason why poultry make such excellent surgical sul)jects lies in their marked resistance to all pyogenic (pus producing) germs.

\section{The Treatment of Cuts, Tears and All Open H'ounds.}

lery severe wounds may be successfully treated by adhering to the following procedure:

I. Thoroughly wash the hands in warm water, using plenty of soap. before handling the wounds at all. After the hands have been well serubbed, rinse them thoroughly in a pan of $I$ to rooo bichloride of mercury solution (p. 29) and dry with a clean towel.

2. Pull out the feathers in the region around the wound, and thoronghy cleanse it, using first atom atater, and follow this with a'arm I to rooo bichloride solution. I piece of clean soft cloth may be used for this purpose, or absorbent cotton. Make sure that the wound is thoroughly clean. Do not he afrairl of hurting the bird. A little pain at the start is preferable to a deats bird later.

3. If necessary sew up the wound, using a goorl sized sewing needle and silk. Both needle and silk should be soaked in alcohol for 15 minutes before using. Small wounds need not be sewerl. Large ones will heal much quicker and more certainly if they are sewerl. If the wound involves the muscles as well 
as the skin sew it up in two layers: one set of stitches including only the muscles, the other set only the skin.

+. I'aint the skin in the region alsout the wound, but not the wenud itsilf with dilute tincture of iodline.

5. Poweler the wound well with iofloform.

6. Smear a thick layer of the ointment already recommended (1). 30) over all.

7. If the wotnd is very severe bandage it with a clean cloth.

The above treatment is only necessary in its entirety in very severe cases. Depending upon the gravity of the condition the following items in the treatment may be omitted in the order nameel:

7 may be omitted except in most serions cases.

7 and 3 may be omitted in less severe cases.

7.3 and + may be omitted in still less severe cases.

$7.3 .+$ and I may be omitted in still less severe cases.

In case of slight wounds which appear still to demand some treatment 6 and 2 or even 6 alone will suffice.

\section{Abscess.}

Shomld an abscess appear lance it with a clean sharp knife. making sure to cut to the bottom. Sipueeze out the pus and core if there is one. and then proceed to heal it by following the treatment above outlined for wounds in general.

\section{Bumblefoot.}

'This is an alsscess of the foot which may result from a variety of causes, e. g.. too high roosts, too narrow roosts, undiscovered wotmels cattsed by stepping on nails, splinters of glass, etc. It is ustally not discovered until the birl becomes lame.

The best treatment to follow is first to tie a cord tightly about the leg above the foot to control the flow of blood; then with a clean, narrow bladed. sharp knife open up the abscess thoroughly. Co clear to the bottom and clig out the core. Then follow in ditail. omitting nothing arept 3 , the treatment given above for woumcls. Two days after the first treatment take off the bandages and repeat the treatment. going through in order steps. I. 2. 4. 5.6 and 7. In some cases a third treatment after a lapse of 2 or 3 days may be necessary, but usually not if the first treatment is thorough. 
Of contse the bird under treatment should be isolated and kept in a small pen with soft litter on the floor.

\section{Broken Bones.}

If a bird is sufficiently valualsle to warrant the trouble it is possible to set fractures of the long bones of legs and wings, and get successful union. A splint should be made for the affected part and carefully and thoroughly bound into place. Healing is rapid, and it should be possible to remove the splints in three weeks from the time they are put on if not before. In our cxperience firm union has occurred in less time than this.

\section{Froscn Combs and IT'attles.}

In northern parts of the country frozen wattles and combs. especially in male birds, are very common occurrences. The trouble is more apt to be with the wattles than the comb. becanse the former dip into the drinking water and then freeze at times when if dry, they would not do so.

The following brief but adequate directions for treating frozen combs and wattles are taken from Farm Poultry, Vol. 15. P. $f^{1}$ : "First thaw the wattles or combs out by manipulating with the fingers well smeared with vaseline. Keep the bird in a cool (not cold) place, and anoint the frozen parts with a mixture of vaseline, 5 tablespoonfuls; glycerine, 2 tablespoonfuls; turpentine. one tablespoonful, once or twice a day. If he is not very badly frosted it probably will make no difference with his breeding a few months from now-provicled he is not again injured the same way."

\section{Ancsthotiaing Poultry.}

From time to time request come to the station for information regarding the most satisfactory method of anaesthetizing lirds. () n this account it seems desirable to republish the following material extracted from a paper written some time age ly. R. l'earl and Frank .I. Surface on this sulbject (four. Aner.

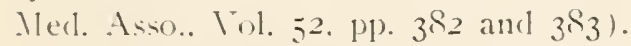

"The difficulty which we have found to be inherent in anesthetizing the fonestic fowl may be stated brietly in this way: If any anesthetic is pushed to the proint at which the bircl is in satisfactory condition for operative procelure in alout 9 cases out of 10 the bird will die on the talle from the effects of the 
anesthesia befure the operation, if extensive, can be completed. lif, on the other hand, the anesthetic is given less freely the bird does not lose its reflex excitability. Eivery time a cut is made or an nuve is pinched with the forceps the bird will struggle. Our experience in anesthetizing birds, which has now covered a large number of individuals. leads us to believe that the only middle ground between these two extremes is afforded by those cases (unfortunately too few) in which the individual idiosyncrasy of the bird toward ether makes it take the anesthetic well.

While we have made no detailed physiologic study as to the funclamental reasons underlying this difficulty respecting anesthesia which has been described, it seems reasonably apparent II hat these reasons are. Connected with the respiratory organs proper of a bird are the relatively enormous air sacs. During ancsthesia the ether or chloroform vapor gets into these air sacs either by diffusion or directly as a result of respiratory movements. There is reason to believe that the vapor, once in the air sacs, stays there until it is absorbed by the tissues; in other words, it appears to be the case that the great bulk of an inhaled anesthetic in the case of birls must be climinated from the body by way of the urinary organs rather than the respiratory organs. Assuming this to be the case there is no difficulty in seeing why forcing an anesthetic in a bird leads to disastrons results. The relatively enormous area for absorption afforded by the air sacs insures that a correspondingly large amount of the ancsthetic will be taken up very quickly. This almost immeciately affects the vagus center, with the consequent cardiac inhibition, respiratory failure and death.

The exact method of procedure which we now follow in ancothetizing bircts is as follows: Immerliately before beginning the alministration of the anesthetic a $\mathrm{I}-200$ grain atropin sulphate tablet is dissolver in I c. c. of warm normal saline solution. The salt solution with the dissolved atropin is then injected subcutaneons ly in the axilla. Ether is used as the anesthetic. It is administered from a snall improvised mask which admits of the condition of the comb being seen during the operaton. Depending on how hard the ether is pushed, the bird is radly for operation in from 15 to 20 minutes after the ane-thesia is begun. The dosage of 1-200 grain atropin to a lird may seem large, but we have never been able to see the slightest bad effect from it, provided the administration of ether was lecrun immediately after the injection of the atropin." 


\section{Glossary or 'Techichicat 'Terms.}

Abdomin. That portion of the body which contains the internal or gaus. Belly.

Air sac.-One of the membranous sacs filled with air in different parts of the body, especially in the abdoninal region. They often extend into the carities of the bones and connect with the lungs.

Albumen portion of oriduct.-See p. 157 .

Anacmia-A condition in which the llood is deficient either in quality or quantity. It is nuarked by paleness and loss of energy.

Anus.-The external opening of the intestine. Vent. Apathctic,-Iacking in feeling or ambition. Indifferent.

Arachnida.-A class of invertebrate animals including among other groups the spiders, scorpions and nites.

Articular.-Pertaining to the joints.

- Istringent.-Causing contraction and arresting discharges.

Atony.-Lack of normal tone or strengtls.

Atrophy.-A wasting of diminution of tha size of : part.

Auditory mcatus.-The opening into the eas.

Avian.-Pertaining to birds.

Arrilla.-The region under the wing where the latter joins the body.

Bile.- The stubstance secreted by the liver. Call.

Bronchi.-The tubes which lead from the end of the windpine (trachea) to the two lungs. (cf. fig. I2).

Carcinoma.-A malignant tumor or cancer.

Cathctir.- I tubular surgical instrument for discharging fluids from a cavity of the body or for distending a passage.

Cocum (flural ixa).-A blind intestinal pouch of which there are two in the fowl.

Cill. - Tlie smallest element of an organized body that manifests independent vital activities. A morphological or structural unit of an organism.

Chronic- - Long continued but not acute.

Clearage-The division of the cells of an embryo.

Cloaca-The enlargeal portion of the alimentary canal just before the vent. The intestine, the ureters (tubes from the kidneys) and the oviduct open into the cloaca.

Conjunction.-The delicate membrane that lines the eyelids and covers the eyeball in front. 
Comfagions. I discase which is communicalole by direct contact.

Copulotion.-sexnal intercourse. With fowls "treading."

Cimed. The hard tranuparent structure forming the anterior part of the eycball.

Creolin.-A thick black linuid enal tar prepatration. It has antiseptic propertics.

Crisol-1 coal tar product with antiseptic and germicidal properties. Cyst.-A sac-like growth which usually contains a liquid or a semi-solid. hemulecut.-A sonthing mucilaginums or oily medicine.

hormoid cyst-A form of congenital cyst often containng skin-like structures.

biurefic.-A medicine that increases the activity of the kidneys.

IEchymosis (ck-kim-o-ses). - Discoloration of the skin caused by blood outside of the hlond vessels as in a bruise.

limacioted-Very lean or wasted condition of the body.

lincma. A liquid injection in the rectum or cloaca.

Iinteritis.-Inllammation of the intestine. In human me licine confuned chiefly to the small intestine.

Fidemic.-A disease that is widely prevalent in a commmity or locality. Epidermis.-The outer or non-vascular layer of the skin. The cuticle. Fipithclioma.-A cancer or malignant tumor consisting chicfly of cells derived from the skin or mucons membranc.

lipithelium.-The covering or outer layer of the skin and mucous membranes.

Ergot.-A fungus which affects and funally replaces the seer of a cereal grass. Used chiefly in connection with the ergot of rye which is poisonous to poultry. Erget as a drug has the property of causing the mammalian uterus to contract.

Etiology-The causation of any disease.

Firudate.-A substance thrown out of the body or deposited in a tissue by a vital process.

Ficcs.-The excrement or undigested residue of the food discharged from the intestines. Dung. Droppings.

Flagellate micro-organism.-Any minute microscopic organism which swims through the water by means of the lashing Follicle.-See p. 157. of one or more hair-like structures (flagella).

Gall bladder.-The reservoir for the bile or gall secteted by the liver. It is readily seen on the upper side of the liver.

Gallus domesticus.-The scientific name for the domestic fowl.

Gangrenc.-See p. 174. Gangrene of oviduct.

Gastritis.-Inflammation of the stomach.

Hermaphrodite.-An organism which has hoth male and female reproductive organs.

Hemorrhage--Bleeding. A copinus cscape of blood from the vessels. Hepatic.-Pertaining to the liver.

Hyperaemia. Fxcess of blood in any part of the body. 
Hypertrophy-The morbid enlargement or overgrowth of an organ or part.

Immmnity-Security against any particular diseate.

Infetion.-The transmission of disease from one animal to another usually through some intermediate agent.

Infiltration.-The aceumulation in a tissue of substances not normally formel in it.

Inoculation.-The insertion of a virus into a wound or abrasion in the skin in oreler $t 0$ communicate a disease.

Isthmus.-See p. 158.

Keratitis.-Inflamation of the cornea of the eye.

Lar'a.-The first stage in development after leaving the egg. Used in connection with insects, worms, ete.

I.aryn.r.- A muscular and cartilaginous structure situated at the base of the tongue and connecting with tive windpipe (trachea). It is the organ of voice.

Lesion.-. Any hurt, wound or local degeneration.

Lencocytes.-White blood corpuscles.

Lymphatic. Pertaining to or containing lymph which is a transparent slightly yellow liquid which fills the lymphatic vessels. It corresponds in some respects to the serum or liquid portion of the hlood.

Mammal.- Any vertebrate animal which suckles its young.

Melanosis.-Pertaining to an abnormal deposit of pigment.

Mesentery.-The fold of peritonemm attached to the intestines.

Metamorphosis.-In insects the change from larval to adult form as from caterpillar to butterly.

Micro-organism.-Any minute (microscopic) animal or plant. Often used in referring to bacteria or germs.

Mite.-A small arthropod somewhat related to spiders. (Cf. fig. 3r).

Mucosa.-The mucous membrane.

Mucous membranc.-The lining of the internal cavities of the body:

Mucus.-The viscid secretion of certain (mucous) glands.

Mycelium.-The thread-like portion of a fungus. (Cf. fig. 38 ).

Nacreous.-Resembling mother-of-pearl.

Necrotic.-Pertaining to dead or decaying tissue.

Nucleus (P1. nuclei). - A spherical body within a cell. The nucleus is essential to the lite of the cell.

Oesophagus.-That portion of the alimentary canal hetween the mouth (pharynx) and the crop.

Oral.-Pertaining to the mouth.

Oz'ary.-The female sexual organ in which the eggs derelop.

Oriduct.-The tube through which the egg pases from the wary to the cloaca.

Ozum. (plural ova).-The egg. particularly while nu the ovary. (Cf. fig. to).

Panophthalmio.-Inflammation of all the structures or tissue of the eye. Papilla.-A small nipple shaped elevation.

Pathology:-That branch of medicine which treats especially of the tissue changes caused by disease. 
Perticardmu,-lhe membranous sac which contains the heart.

l'ristulsis:- The wam-like movennents of the intestine and oviduct by which the contents of these tulies are propelled.

Firifonilis. Intianmation of the peritonem or the membrame lining the

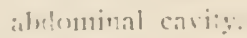

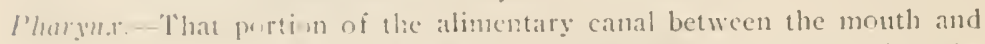
the oesophlitis. It also communicate; with the laryns and nasal passages at its upper end.

Prognoss. Thr prospect as in recovery from a disease or a forecast as to the probable result of an attack of a disease. Protophism.- I viscicl granular material which forms the essential constituent of the living cell. Living substance.

l'rotozur-. I class of micellular animal micro-organisms.

Proźchlriculus.-That portion of a bird's alimentary canal lying between the crop and the gizzard. Often called the stumach.

Punctiform homorhagcs. Presenting the alpearance as if punctured by a large number ni fine prickle or needle holes from whith the blood nozes.

Pugditi-Causing evarnations of the howels.

Pyamiat-B!ood poicon che to microhic urigin.

Saromu. - I kind of tumor or cancer not always of a malignant nature. Scubics-1 contagious skin discasc carsen by a mite.

Sidertic-Pertaining to the hard white fibens membrane which with cornea forms the outermost coats of the eyeball.

Sirmmi-The clear liquid which separates irom the ciot and the corpuscles in the elotting of blood.

Spleru. An oval sliaped organ normally about one-half inch in diameter and of a dark red color. It lies immeniztely above the liver and between that and the proventricinlus. Sporc. - The reproductive cell of many protozoa and of many lower plants. It is usually enclosed in tough menibranes and is difficult to kill.

Stigma.-See p. I 57.

Subcutancons.-Beneath the skin.

Sub-mucosa.-.The layer of tissue situated beneath the mucous membrane.

Syncope (sin-ko-pe).-Fainting. Failure of the heart's actinn.

Tracleca.-The wind-pipe.

Trammatic-Cansed by an iniury.

Therapewic.-Pertaining to the art and science of healing.

Iratc-A salt of uric acid. A product of the secretion of the kidneys. The white part of a fowl's droppings.

Vireters. -The tubes leading from the kidneys to the cloaca.

L'terus.-See p. 158 .

Fagina.-That portion of the nvirnct hetween the shell gland and the cloaca.

Virulcut.-Fixtremely pnisonnus or dangerous

Virus. - Iny animal pricon, especially one produced by an 1 capable of transmitting a discase.

liscrio.-The internal organs of the body. 


\section{INDEX.}

P.AGE:

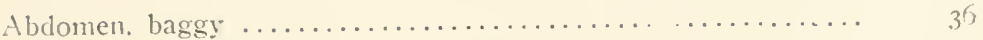

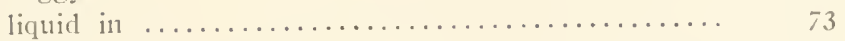

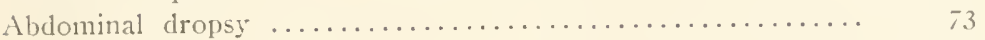

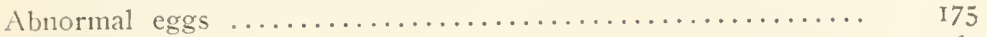

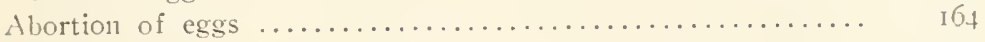

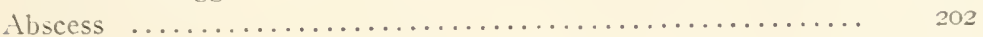

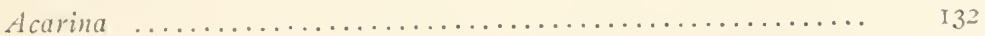

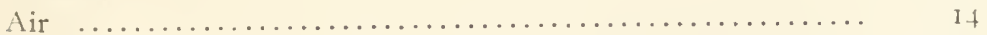

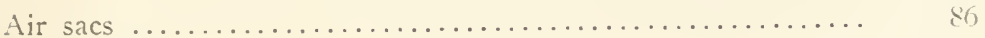

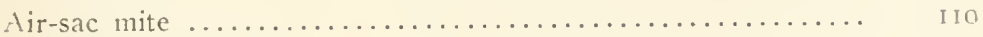

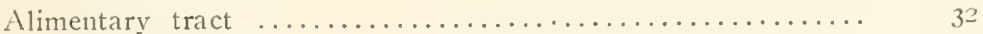

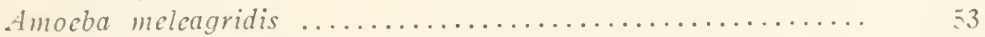

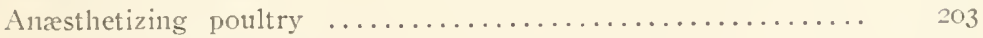

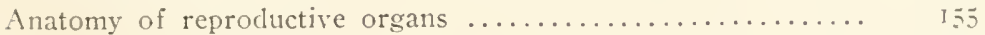

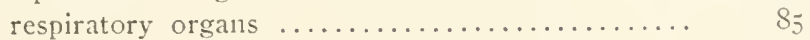

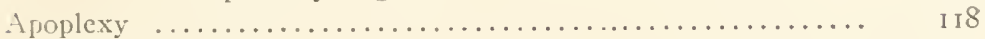

Apothecaries' weights and measures $\ldots \ldots \ldots \ldots \ldots \ldots \ldots \ldots \ldots \ldots$ 3I

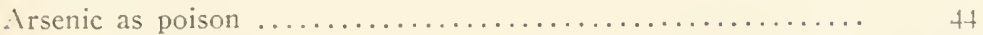

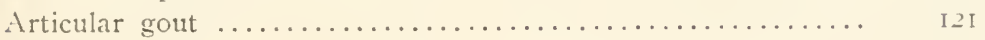

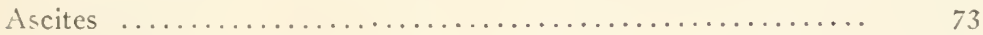

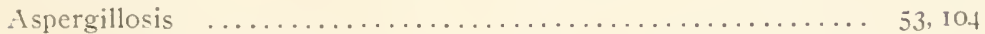

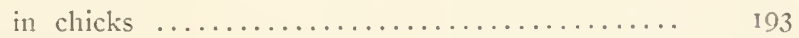

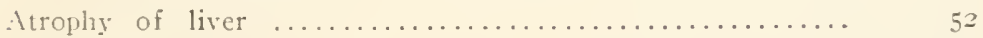

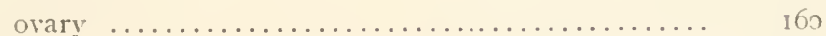

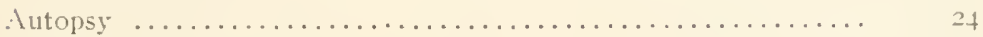

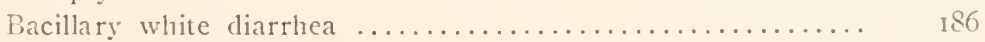

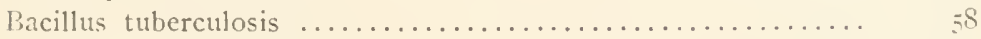

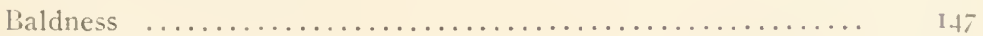

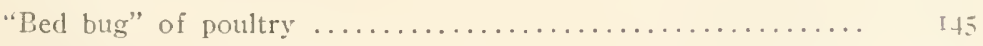

Bichloride of mercury ............................ 29

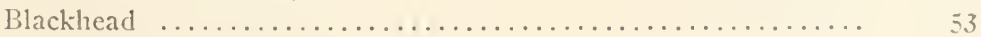

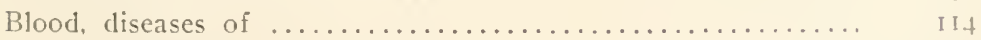

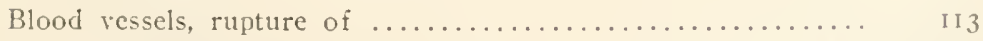

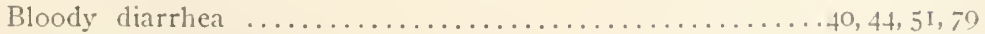

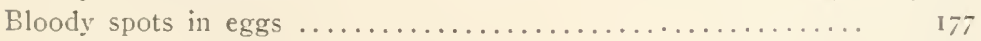

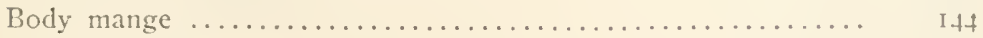

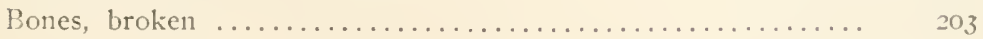


Books on poultry diseases ..................... 2

Brain congestion ................................... I 19

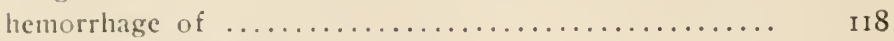

postmortem appearance of .................. IIs

Breaking of egg in oviduct........................... 1 .

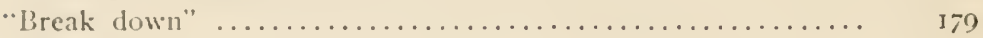

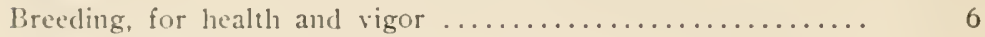

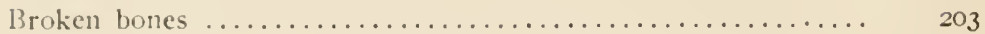

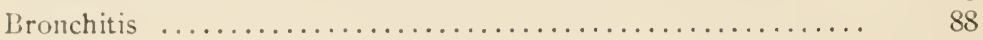

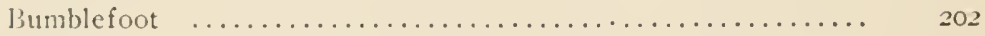

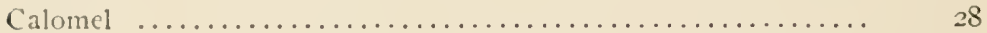

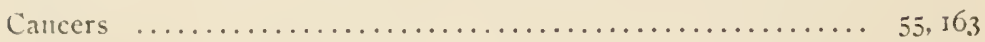

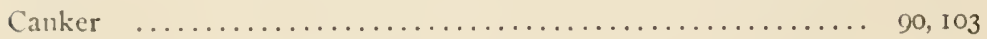

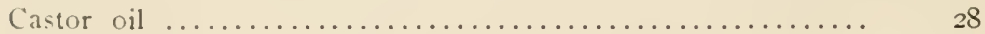

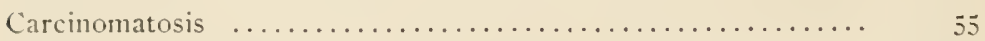

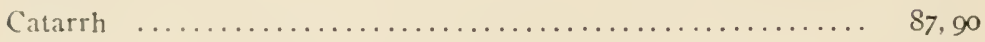

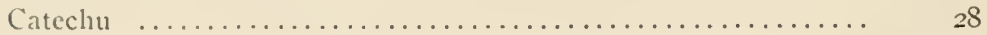

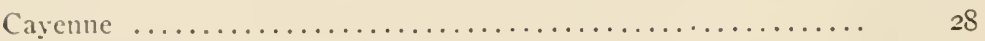

Ceca, post-mortem appearance of $\ldots \ldots \ldots \ldots \ldots \ldots \ldots \ldots \ldots \ldots \ldots \ldots \ldots \ldots$

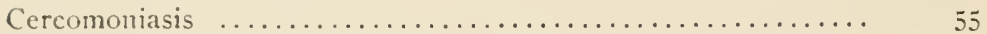

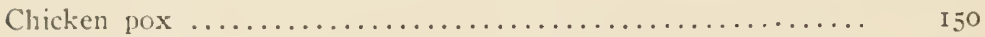

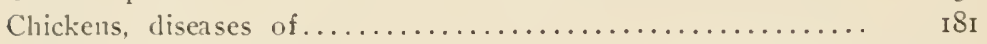

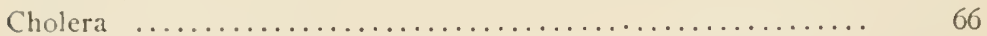

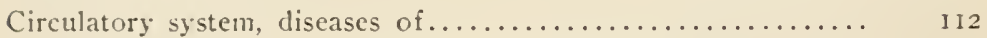

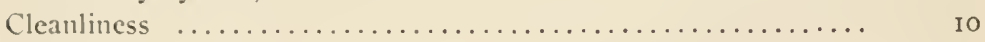

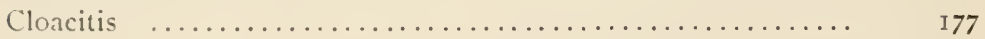

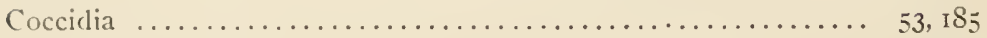

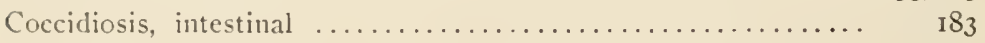

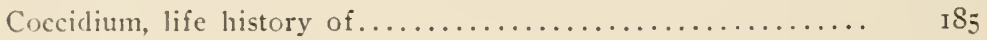

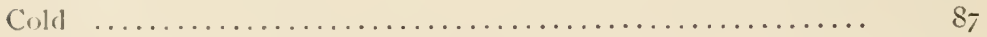

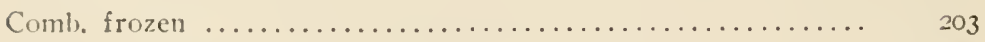

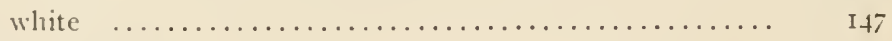

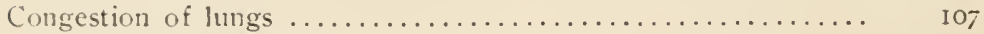

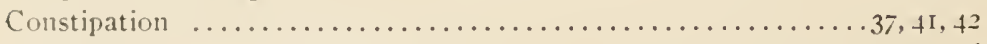

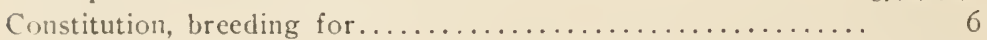

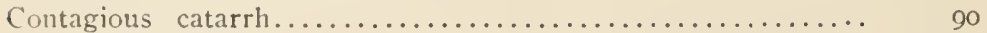

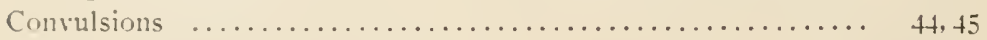

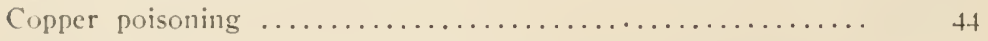

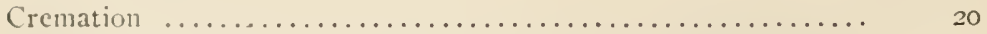

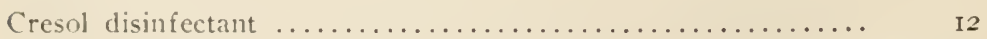

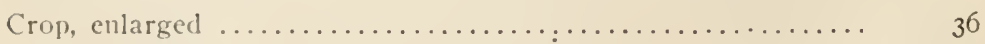

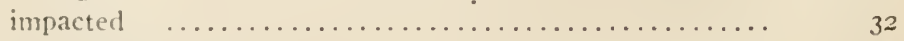

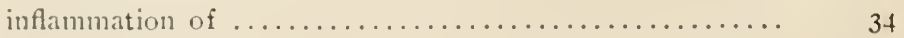

Cropoing poultry ranges........................... I8

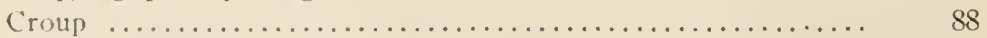

Cuts, treatment of ........................... 20 I

Cylodites uudus .................................. IIo 
PAGF:

Dampliess $\ldots \ldots \ldots \ldots \ldots \ldots \ldots \ldots \ldots$ I5

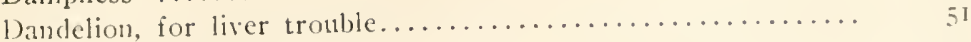

Dead birds, disposal of ........................... 20

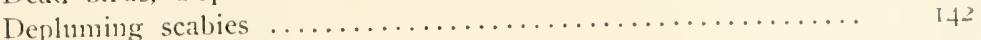

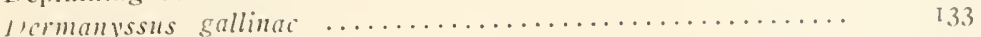

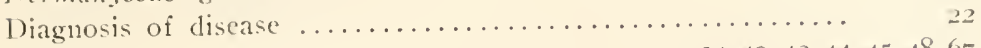

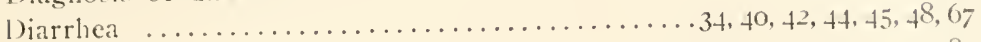

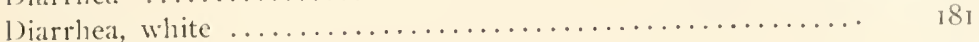

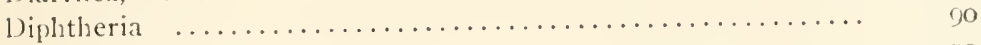

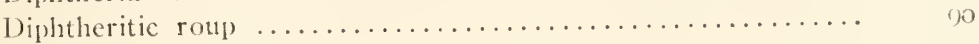

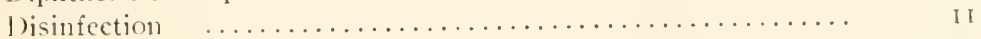

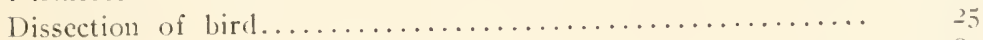

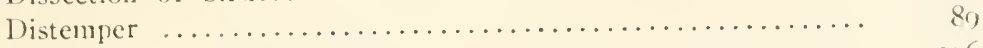

Double and triple yolked eggs....................... I

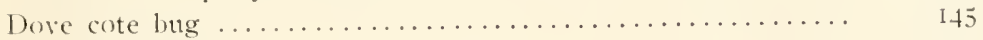

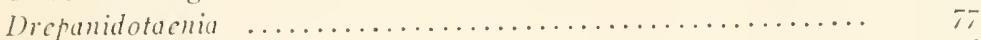

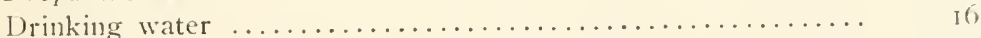

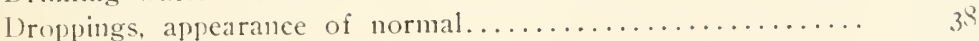

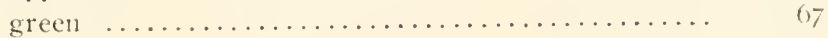

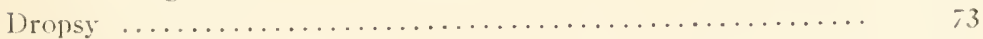

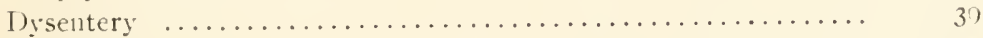

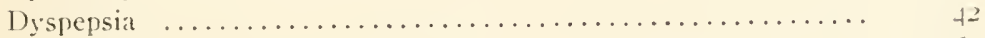

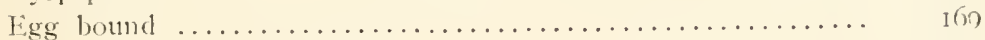

breaking of in oviduct ......................... I

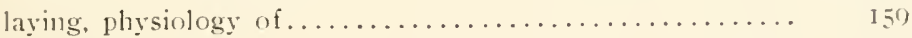

Figs. abnormal ............................ 175

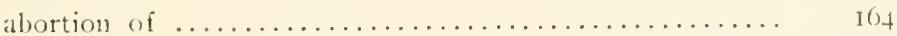

double and triple yolked..................... 1 .

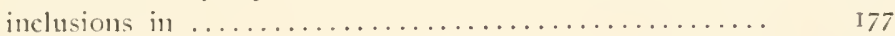

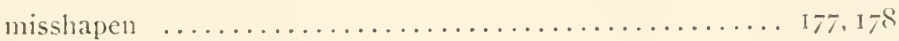

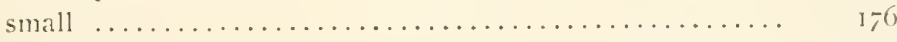

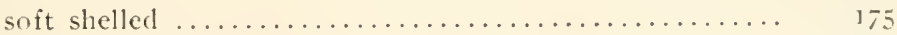

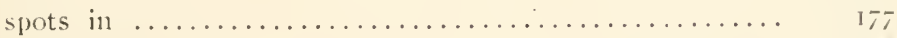

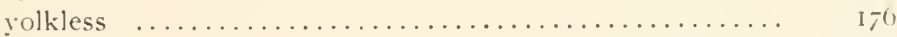

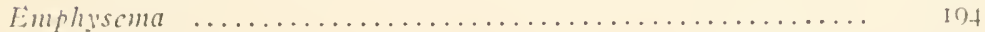

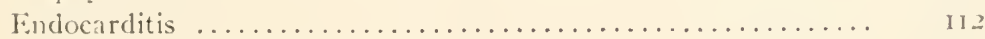

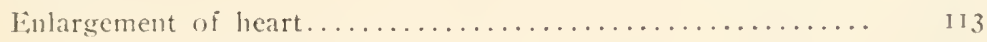

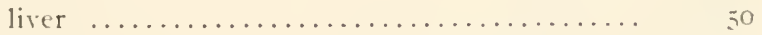

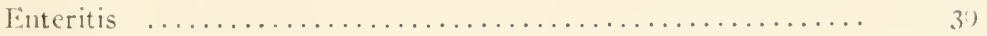

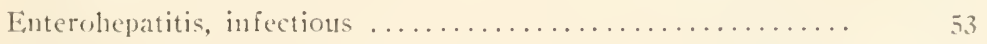

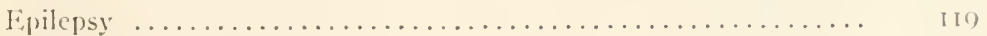

Iipithelioma contagiosum $\ldots \ldots \ldots \ldots \ldots \ldots \ldots \ldots \ldots \ldots \ldots \ldots \ldots$ 150

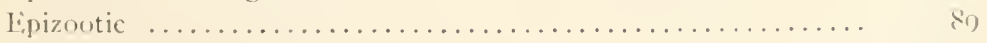

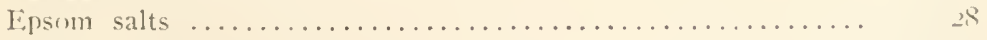

Ergot as puison $\ldots \ldots \ldots \ldots \ldots \ldots \ldots \ldots \ldots \ldots \ldots \ldots \ldots \ldots \ldots$

Eversion of oviduct ........................ If);

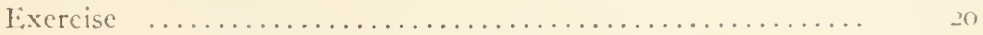




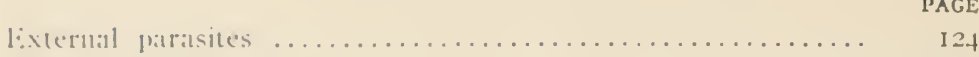

lixtractor, galpe worm ....................... 200

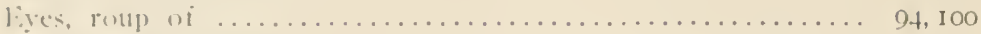

liatty degeneration of liver......................

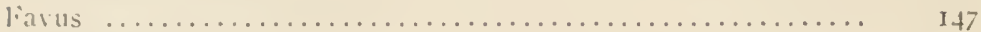

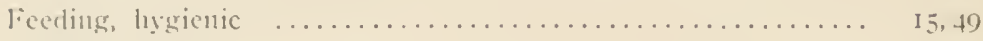

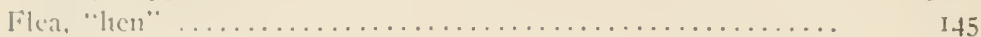

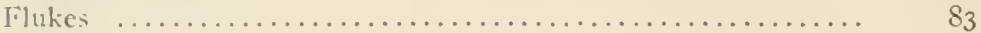

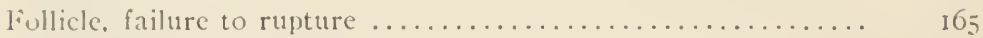

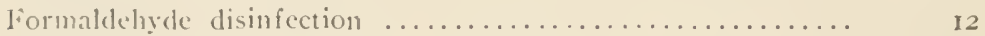

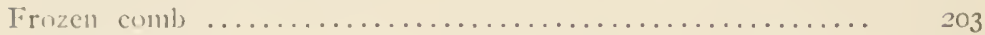

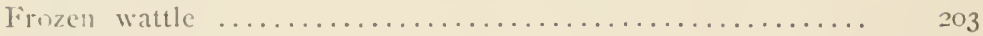

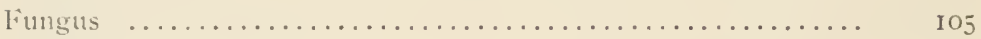

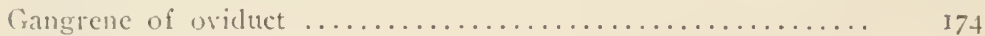

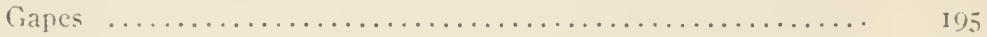

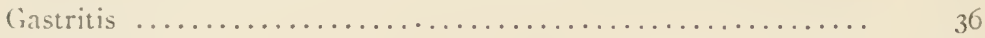

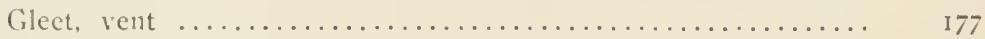

Glossary . . . . . . . . . . . 205

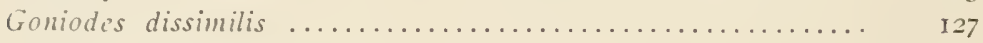

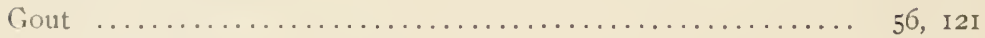

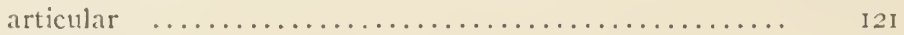

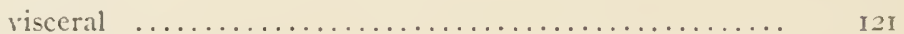

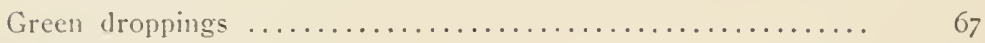

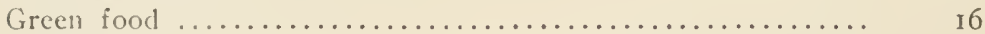

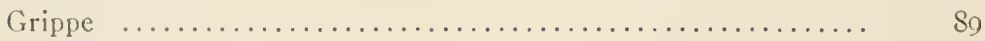

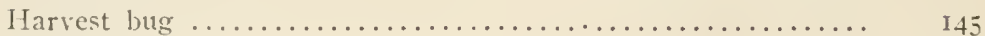

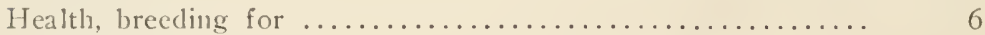

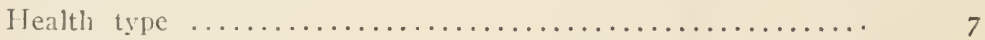

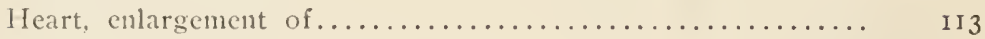
post-mortem appearance of $\ldots \ldots \ldots \ldots \ldots 68$, I12, II3, II5, I2I

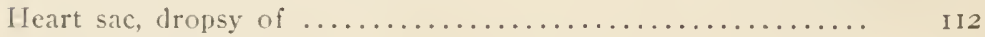

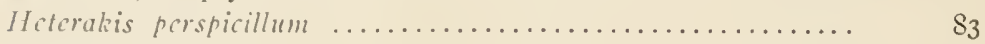

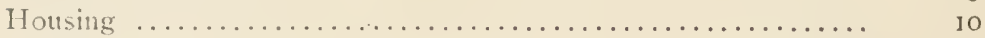

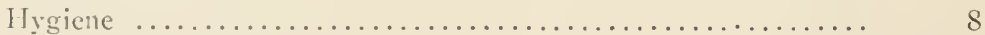

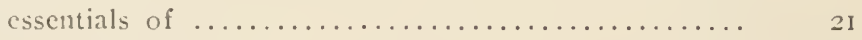

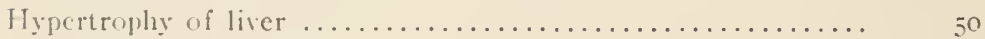

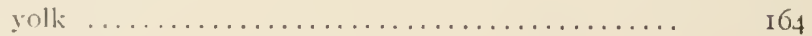

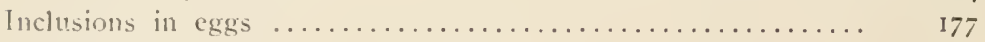

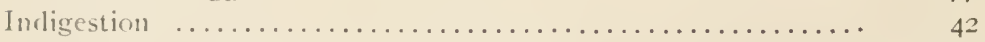

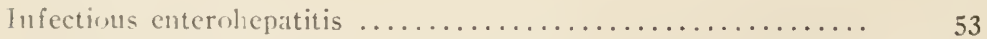

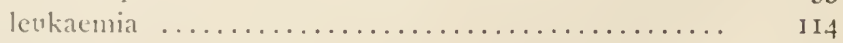

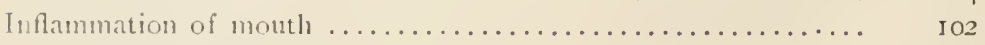

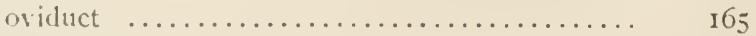

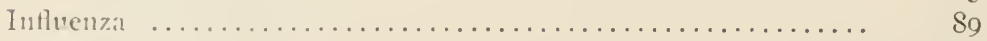

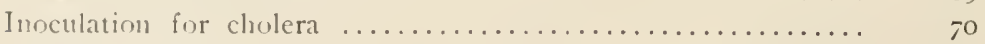

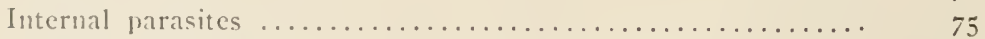

Intestinal coccidiosis $\ldots \ldots \ldots \ldots \ldots \ldots \ldots \ldots \ldots \ldots \ldots \ldots \ldots \ldots \ldots \ldots \ldots$ 
Jaundice

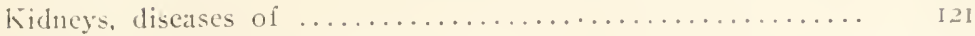

Kidneys, post-mortem appearance of ...........6. I I $3,121,188$

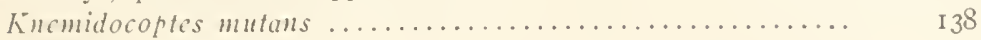

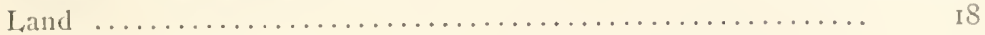

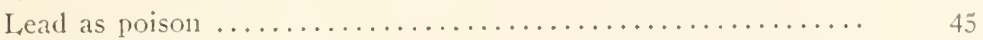

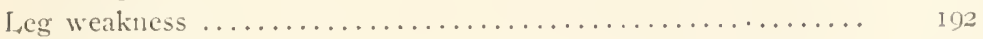

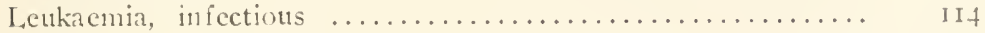

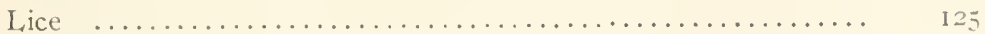

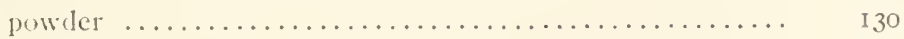

Life history of coccidium $\ldots \ldots \ldots \ldots \ldots \ldots \ldots \ldots \ldots \ldots \ldots$ I $8_{5}$

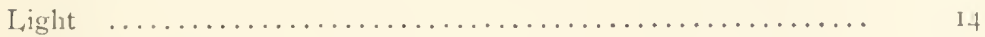

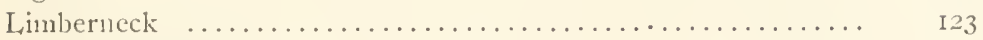

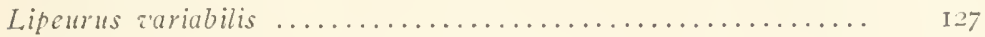

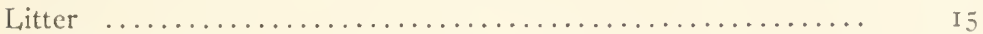

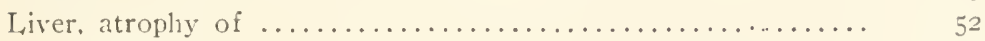

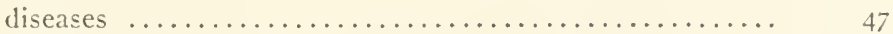

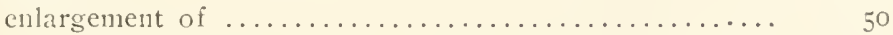

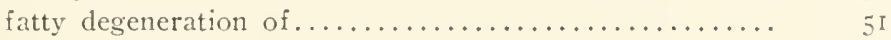

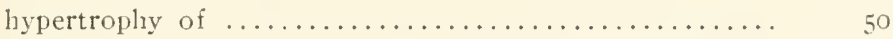

post-mortem appearance of $40,47,49,50,51,52,53,54,55,56,61,68$,

I 13 , I I5, I2I, I 88 , I94

Luings

85

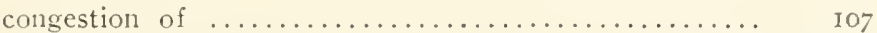

post-mortem appearance of .......... I04, I08, II3, II6, I88, I94

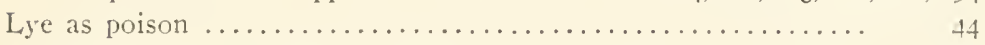

Male reproductive organs, diseases of ............... 180

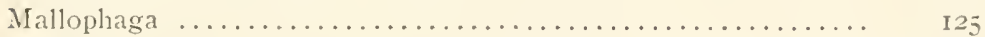

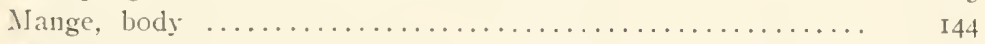

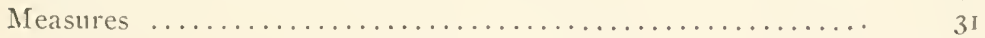

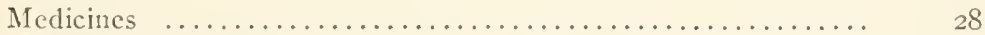

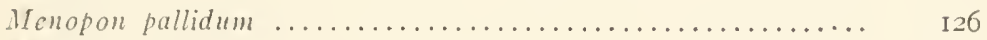

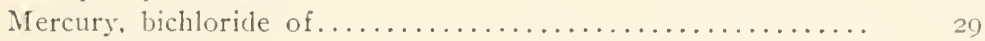

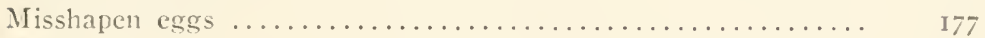

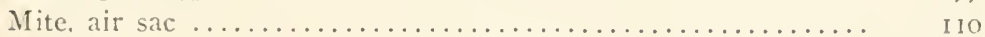

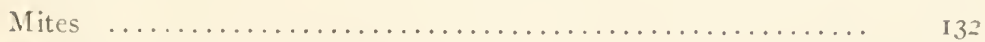

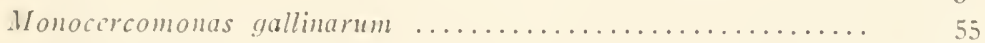

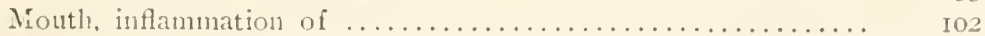

Mycosis of the air passages $\ldots \ldots \ldots \ldots \ldots \ldots \ldots \ldots \ldots \ldots \ldots$ IO 4

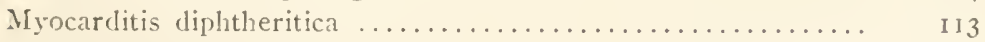

Nervous system, diseases of $\ldots \ldots \ldots \ldots \ldots \ldots \ldots \ldots \ldots \ldots$ II 8

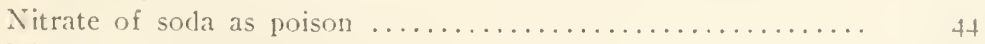

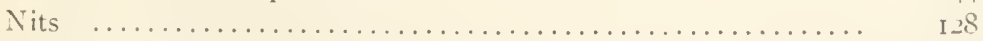

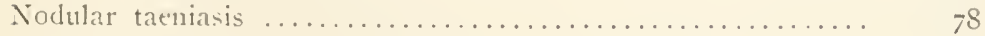

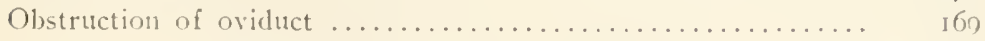

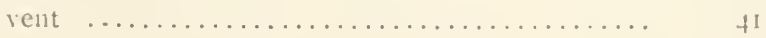




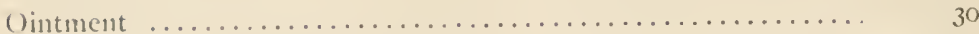

Operation, for "egg bound" .................. I

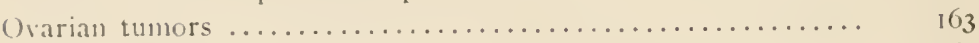

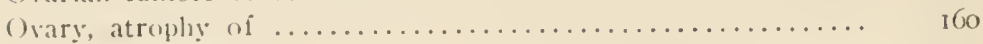

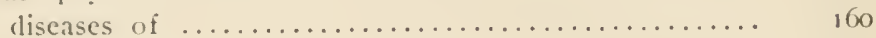

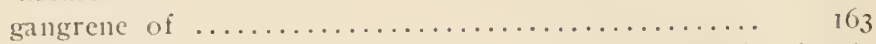

post-mortem appearance of $\ldots \ldots \ldots \ldots$ I60, I61, 162, 163, 164, 165

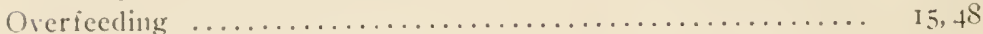

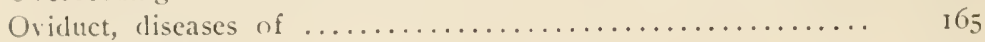

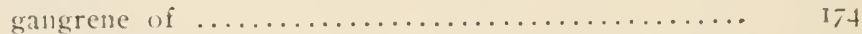

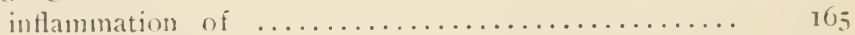

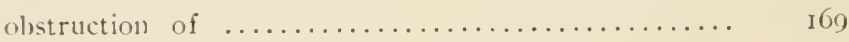

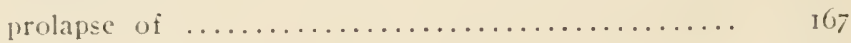

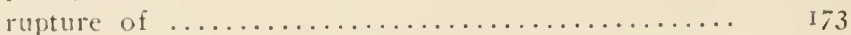

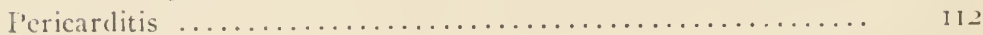

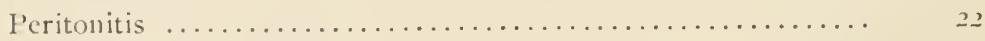

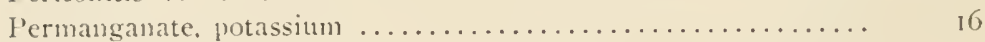

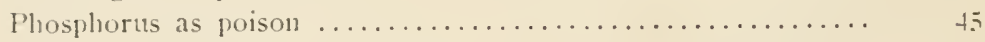

Physiology of reproductive organs $\ldots \ldots \ldots \ldots \ldots \ldots \ldots \ldots \ldots \ldots$ 155

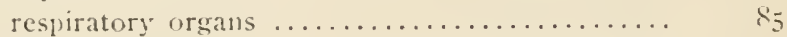

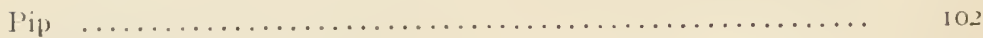

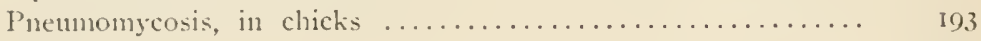

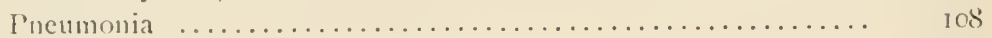

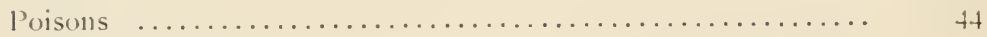

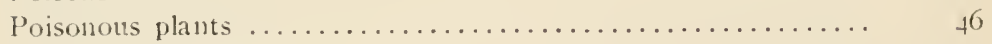

Post mortem appearance of brain.................. Is

ceca $\ldots \ldots \ldots \ldots \ldots \ldots \ldots \ldots \ldots \ldots \ldots \ldots \ldots \ldots, 188$

heart $\ldots \ldots \ldots \ldots \ldots 68,112,113,115,12 \mathrm{I}$

intestines ...40, 50, 62, 68, 79, II 5, 121, 188, 194 kidneys $\ldots \ldots \ldots \ldots \ldots \ldots 68$, I $13,121,188$ liver .....40.47.49 to $56,61,68,113,115.121$, I 88 , I94 lungs ......... I04. I08, I13, II6, I88, I94 orary ...................... 160 to 165 spleen $\ldots \ldots \ldots \ldots \ldots \ldots$ 40, 61, I 13, 121, 188

Post-mortems, how to make ....................... 24

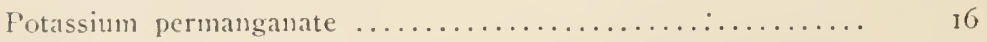

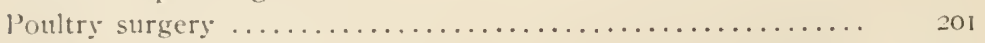

Powder, lice ............................... 130

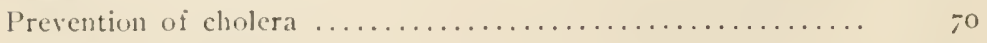

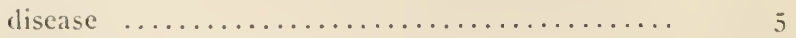

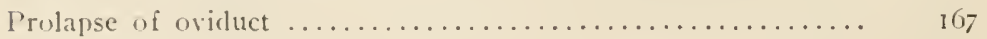

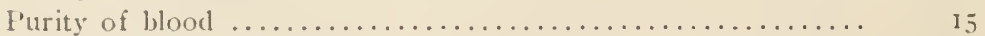

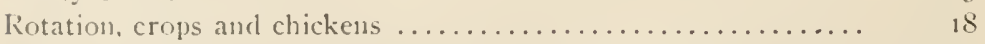

Reproductive organs, anatomy and physiology of ........ 155

diseases of $\ldots \ldots \ldots \ldots \ldots \ldots \ldots \ldots \ldots \ldots \ldots \ldots \ldots$ 
I'AGE

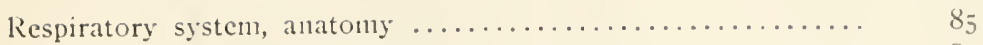

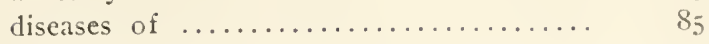

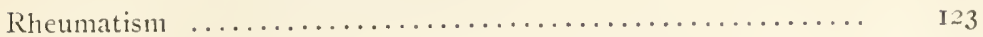

Round worms $\ldots \ldots \ldots \ldots \ldots \ldots \ldots \ldots \ldots \ldots \ldots \ldots \ldots \ldots \ldots \ldots$

Roup .................................. 90

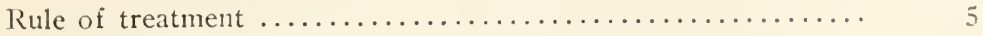

Rupture of blood vessels $\ldots \ldots \ldots \ldots \ldots \ldots \ldots \ldots \ldots \ldots \ldots \ldots$ II 3

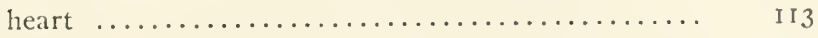

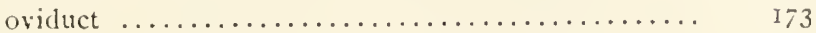

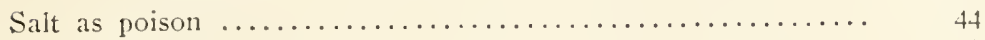

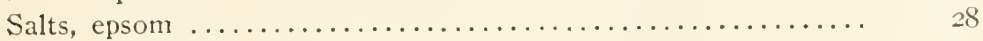

Sanitation $\ldots \ldots \ldots \ldots \ldots \ldots \ldots \ldots \ldots \ldots \ldots \ldots \ldots \ldots \ldots \ldots \ldots \ldots \ldots \ldots$

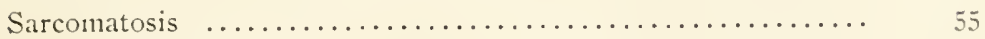

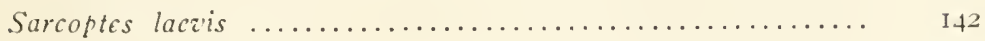

Scabies, depluming ........................ I42

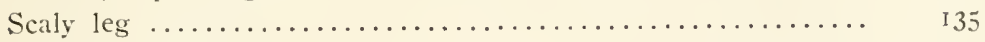

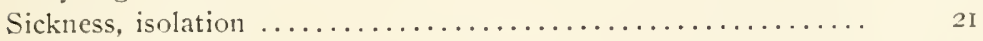

Skin. diseases of $\ldots \ldots \ldots \ldots \ldots \ldots \ldots \ldots \ldots \ldots \ldots \ldots \ldots$ I 47

Small $\operatorname{eggs} \ldots \ldots \ldots \ldots \ldots \ldots \ldots \ldots \ldots \ldots \ldots \ldots \ldots \ldots \ldots$

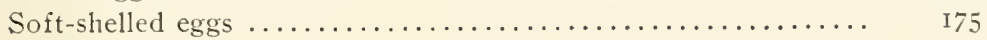

Sore liead $\ldots \ldots \ldots \ldots \ldots \ldots \ldots \ldots \ldots \ldots \ldots \ldots \ldots \ldots \ldots \ldots \ldots$ I50

Spleen, post-morten appearance of ...........40,6I, I I3, I2 I, I88

Spots in eggs ............................... 177

Stock tonic $\ldots \ldots \ldots \ldots \ldots \ldots \ldots \ldots \ldots \ldots \ldots \ldots \ldots \ldots \ldots \ldots \ldots . \ldots \ldots$

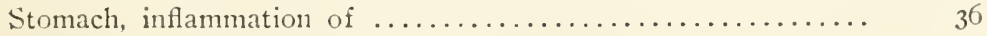

Strychinine $\ldots \ldots \ldots \ldots \ldots \ldots \ldots \ldots \ldots \ldots \ldots \ldots \ldots \ldots \ldots \ldots \ldots \ldots$

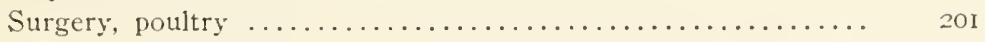

Symplectoptes cysticola ........................ I44

Symptoms, table of $\ldots \ldots \ldots \ldots \ldots \ldots \ldots \ldots \ldots \ldots \ldots \ldots \ldots \ldots \ldots$

Syngamus trachcalis ....................... I96, I97

Table of symptoms ......................... 23

Tablets ................................... 29

Taeniasis, nodular $\ldots \ldots \ldots \ldots \ldots \ldots \ldots \ldots \ldots \ldots \ldots \ldots \ldots \ldots \ldots$

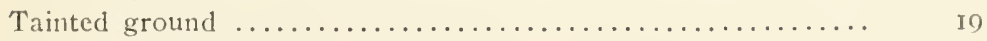

Tape worms $\ldots \ldots \ldots \ldots \ldots \ldots \ldots \ldots \ldots \ldots \ldots \ldots \ldots \ldots \ldots \ldots \ldots$

Tears, treatment of $\ldots \ldots \ldots \ldots \ldots \ldots \ldots \ldots \ldots \ldots \ldots \ldots \ldots \ldots \ldots$

Thrush $\ldots \ldots \ldots \ldots \ldots \ldots \ldots \ldots \ldots \ldots \ldots \ldots \ldots \ldots \ldots \ldots \ldots \ldots$

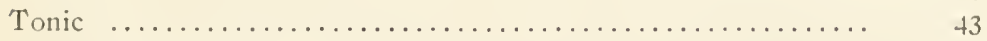

Tuberculosis $\ldots \ldots \ldots \ldots \ldots \ldots \ldots \ldots \ldots \ldots \ldots \ldots \ldots \ldots \ldots \ldots$, $\ldots \ldots \ldots$

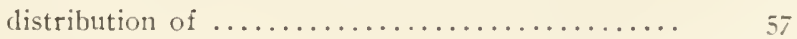

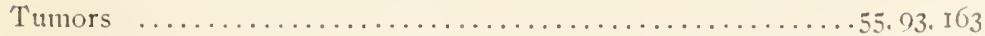

$V^{\top}$ ent gleet $\ldots \ldots \ldots \ldots \ldots \ldots \ldots \ldots \ldots \ldots \ldots \ldots \ldots \ldots \ldots \ldots \ldots \ldots$

Vertigo $\ldots \ldots \ldots \ldots \ldots \ldots \ldots \ldots \ldots \ldots \ldots \ldots \ldots \ldots \ldots \ldots \ldots$ II

Vigor, breeding for $\ldots \ldots \ldots \ldots \ldots \ldots \ldots \ldots \ldots \ldots \ldots \ldots \ldots \ldots$

Tisceral gout $\ldots \ldots \ldots \ldots \ldots \ldots \ldots \ldots \ldots \ldots \ldots \ldots \ldots \ldots \ldots \ldots$

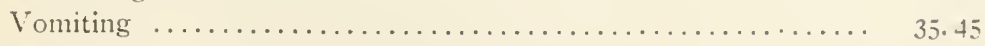

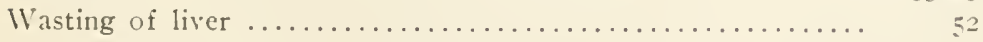




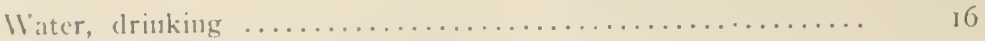

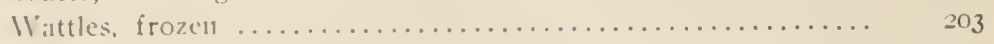

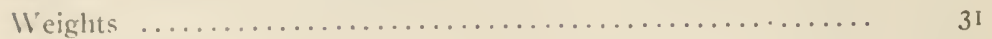

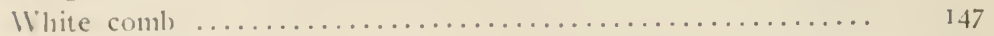

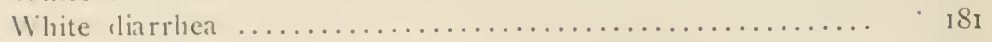

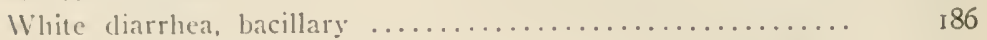

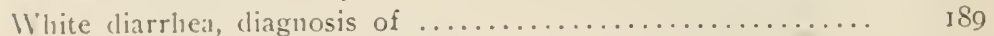

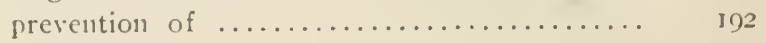

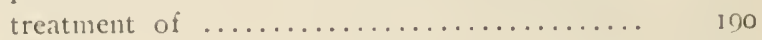

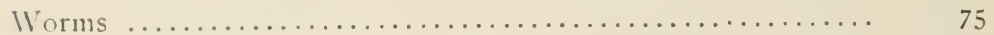

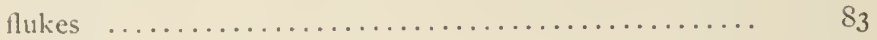

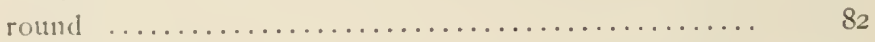

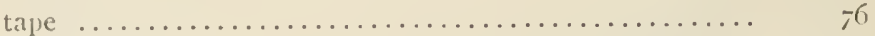

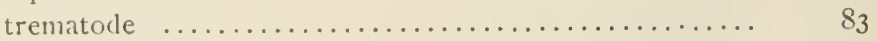

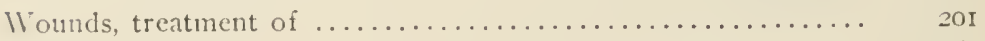

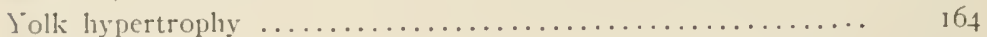

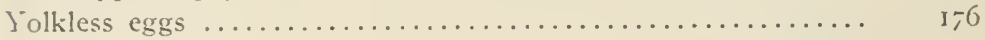

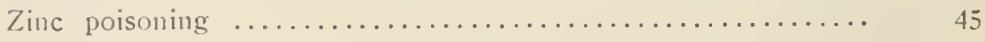




$$
\begin{aligned}
& 10 \\
& \text { in } x^{4} y^{2}
\end{aligned}
$$

$$
\text { I. }
$$

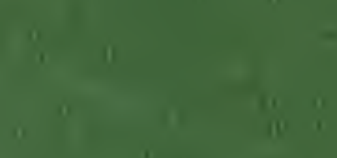

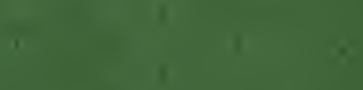$$
\text { (2. }
$$
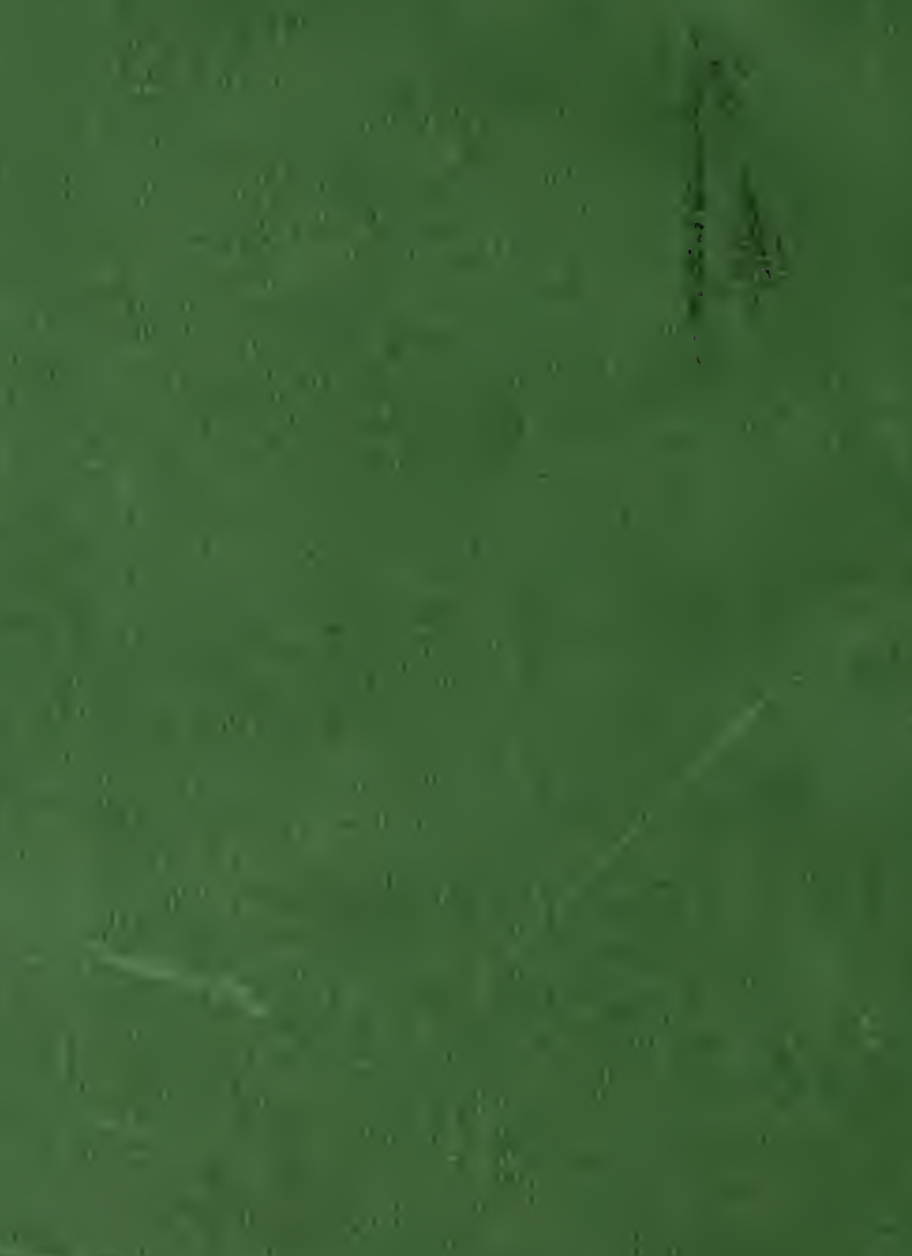

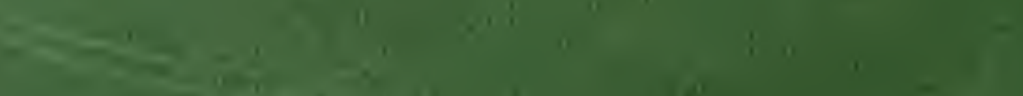

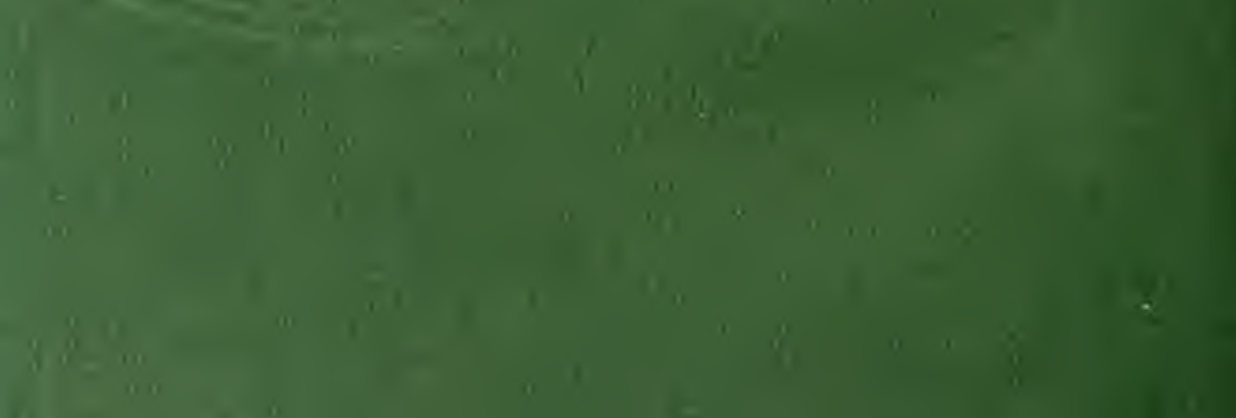





THIS BOOK IS DUE ON THE LAST DATE STAMPED BELOW

AN INITIAL FINE OF 25 CENTS WILL BE ASSESSED FOR FAILURE TO RETURN THIS BOOK ON THE DATE DUE. THE PENALTY WILL INCREASE TO 50 CENTS ON THE FOURTH DAY AND TO $\$ 1.00$ ON THE SEVENTH DAY OVERDUE.

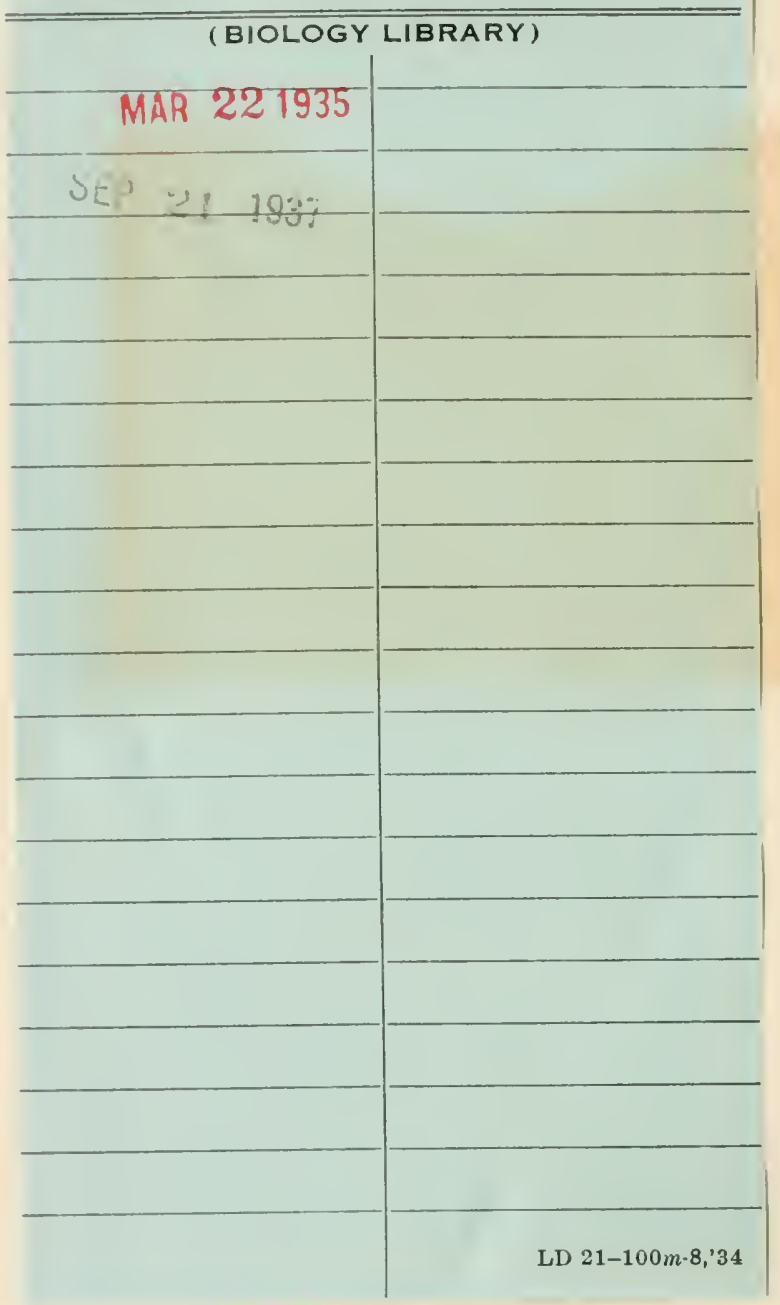




\section{9}

UNIVERSITY OF CALIFORNIA LIBRARY 
